RenAta NAtSumi Haneda

\title{
INVESTIGAÇÃO DO DESEMPENHO DE DIFERENTES \\ ESTRUTURAS MICROPOROSAS TUBULARES NA \\ RETENÇÃO DE BACTÉRIAS EM SUSPENSÃO POR MICROFILTRAÇÃO TANGENCIAL
}

\begin{abstract}
Dissertação apresentada à Escola de Engenharia de São Carlos da Universidade de São Paulo, como parte dos requisitos para a obtenção do Título de Mestre em Engenharia Mecânica.
\end{abstract}

Orientador: Prof. Dr. Sérgio Rodrigues Fontes

São Carlos

2006 
Ficha catalográfica preparada pela Seção de Tratamento da Informação do Serviço de Biblioteca - EESC/USP

H237i

Haneda, Renata Natsumi

Investigação do desempenho de diferentes estruturas microporosas tubulares na retenção de bactérias em suspensão por microfiltração tangencial / Renata Natsumi Haneda. -- São Carlos, 2006.

Dissertação (Mestrado) -- Escola de Engenharia de São Carlos-Universidade de São Paulo, 2006.

Área: Engenharia Mecânica.

orientador: Prof. Dr. Sérgio Rodrigues Fontes.

1. Escherichia coli. 2. Microfiltração. 3. Meio microporoso. 4. Alumina. 5. Prata. 6. Soro de leite. I. Título. 


\section{FOLHA DE JULGAMENTO}

Candidata: Bacharel RENATA NATSUMI HANEDA

Dissertação defendida e julgada em 29-03-2006 perante a Comissão Julgadora:

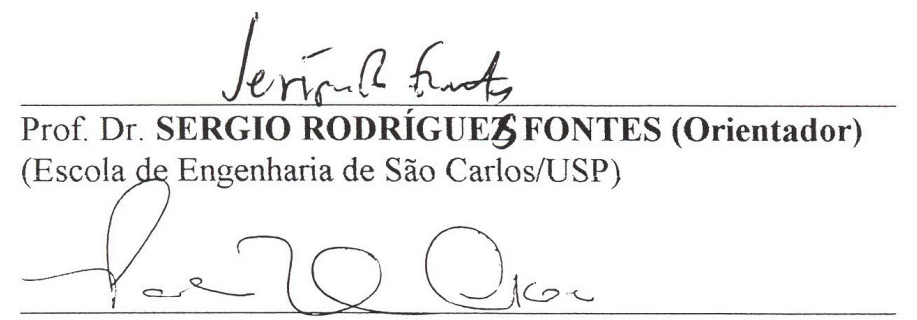

Dra. PAULA CRISTINA GARCIA MANOEL CRNKOVIC

(Pós-Doutoranda/FAPESP)

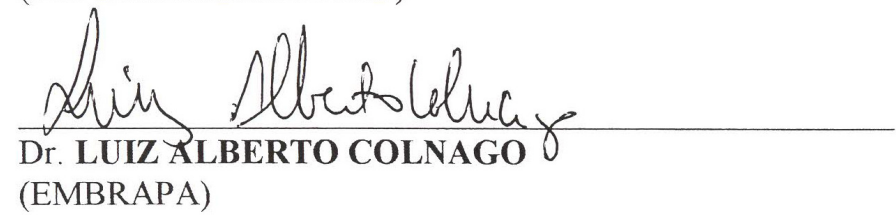

ARROVARA

(Escola de Engenharia de São Carlos/USP)

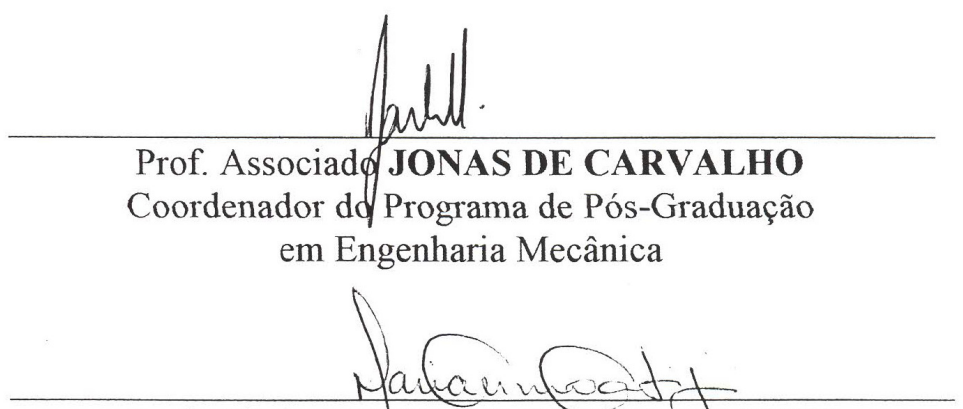

Profa. Titular MARIA DO CARMO CALLIJURI

Presidente da Comissão de Pós-Graduação 


\section{Dedicatória}

Dedico este trabalho a três pessoas fundamentais nessa etapa, sem as quais eu não teria passado por essa trajetória: ao meu pai, Sr. Takeshi Haneda, meu esteio; à minha mãe, Herta B. Haneda, minha melhor amiga e companheira; e à minha irmã, Lilian M. Haneda, meu exemplo de vida. 


\section{AGRADEÇO:}

Primeiramente, a Deus por todas as bênçãos, força, ensinamentos e divina luz para que eu vencesse todos os obstáculos e realizasse mais esse grande sonho;

Aos meus familiares que mesmo longe, procuraram sempre me incentivar e ajudar;

Ao meu orientador, Prof. Dr. Sérgio R. Fontes, principalmente por acreditar na minha capacidade, pela confiança, apoio, paciência, atenção e orientações que me fizeram seguir em frente, não desistir do meu trabalho e vencer as dificuldades;

Ao Prof. Dr. Elson Longo, diretor do LIEC/UFSCar - Laboratório Interdisciplinar de Eletroquímica e Cerâmica por gentilmente ceder materiais e os laboratórios do LIEC, para desenvolvimento de técnicas novas, além dos conhecimentos transmitidos que fortaleceram o meu trabalho e a minha formação acadêmica;

Ao Dr. Luis A. Daniel, chefe do Departamento de Hidráulica e Saneamento, da Universidade de São Paulo - São Carlos, pela autorização do uso do laboratório de Hidráulica e Saneamento, para a realização de análises microbiológicas;

Ao diretor da Tecnicer Cetebra LTDA (São Carlos - S.P.), Eng. Luís Fernando Porto, por ceder tubos cerâmicos para serem estudados;

Ao Prof. Dr. Carlos A. Fortulan e ao mestre Rogério Ikegami, do Laboratório de Tribologia e Compósitos (EESC/ USP), por colaborarem na confecção de tubos cerâmicos utilizados no meu trabalho, pela atenção e incentivo que muito contribuíram para o desenvolvimento desse projeto; 
A todos os funcionários da Cooperativa de Laticínios de São Carlos (COTILASC - São Carlos - S.P.), pelo fornecimento da matéria-prima para a realização de todos os experimentos;

Ao Dr. Julio Trofino, Dr. Paulo Fragiácomo e a Bel. Juliana G. dos Santos, pela atenção, paciência e auxílio das análises microbiológicas feitas no Laboratório de Hidráulica e Saneamento, da Universidade de São Paulo - São Carlos;

Ao Umberto C. Petracon do Centro de Tecnologia Educacional para Engenharia (CETEPE), da Universidade de São Paulo - São Carlos, pelas fotografias tiradas dos experimentos e toda a atenção dedicada para 0 desenvolvimento desse trabalho;

Aos mestres, Mario Godinho e Luis P. S. Santos, da Universidade Federal de São Carlos, por transmitirem conhecimentos e me auxiliarem na pesquisa, contribuindo para a realização do meu projeto;

Ao Sr. Hélio J. D. Trebi e ao Sr. Theodomiro F. Luchesi, do Laboratório de Térmica e Fluidos, no Departamento de Engenharia Mecânica - EESC, por toda a atenção, auxílio e paciência na manutenção da bancada de ensaio desse trabalho;

Ao meu noivo, Eduardo Alves Figueiredo, pela paciência, carinho, e atenção;

À minha amiga, Grazieli L. C. Carosio, pela amizade sincera, paciência desde o início dessa etapa e apoio nas horas mais difíceis, confortando-me com palavras de carinho e de incentivo;

Ao Dr. Wilson T. L. da Silva, ao Dr. Antonio P. de Novaes, ao Dr. Marcelo Simões e ao Dr. Luis A. Colnago, pesquisadores da Embrapa Instrumentação Agropecuária CNPDIA - São Carlos, pelo apoio e incentivo para que eu iniciasse mais essa etapa;

À Dra. Paula Crnkovic e a mestre Ivonete Ávila, pela paciência e boa vontade em compartilhar um pouco de seus conhecimentos para a realização e transformação desse trabalho; 
À Lucimar L. Fialho e a Martha G. Peres, pela amizade e incentivo para que eu realizasse esse projeto;

À Teodora Figueroa, pela amizade e apoio para que eu seguisse sempre em frente;

Aos meus amigos, Ricardo B. Rizzo e Elaine Simionato, pelo incentivo, apoio e as noites em claro, estudando;

Aos meus colegas de sala, Roberta Del Colle, Juliana Maria da Silva e Ernesto Beck, pelo incentivo, companheirismo e paciência nesses dois anos;

E a todos os professores, colegas e funcionários do Departamento de Engenharia Mecânica, da Universidade de São Paulo - São Carlos, pelo incentivo, apoio e por compartilharem seus conhecimentos; 


\section{SUMÁRIO}

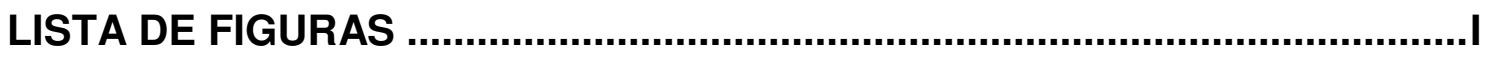

LISTA DE TABELAS

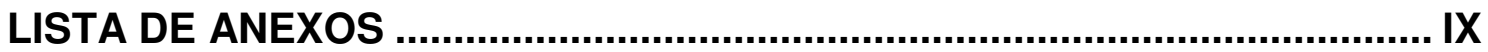

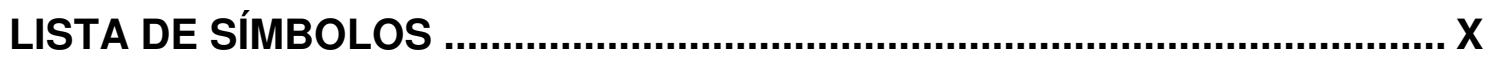

RESUMO

ABSTRACT

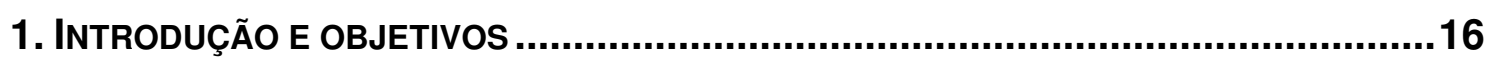

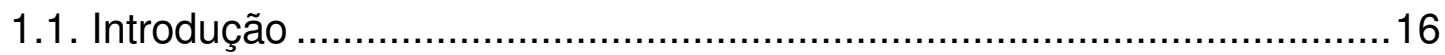

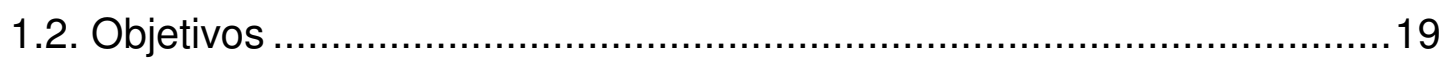

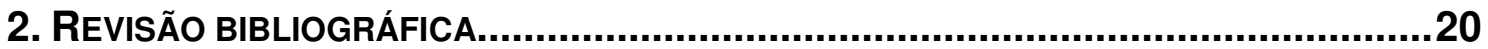

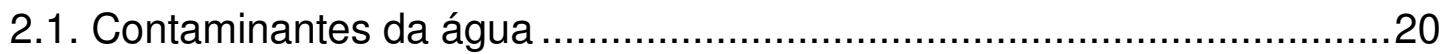

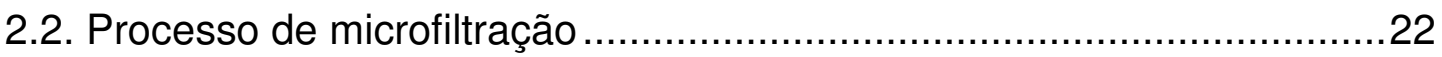

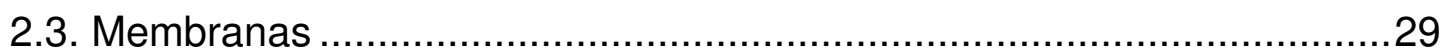

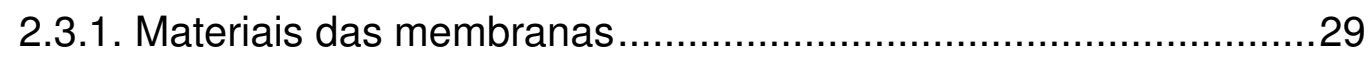

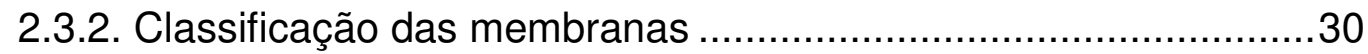

2.3.3. Características da filtração com membranas ...............................31

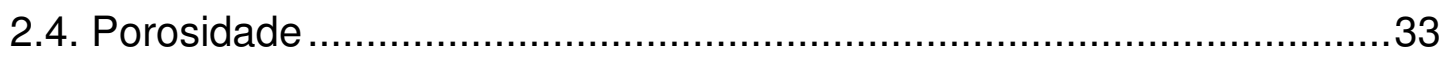

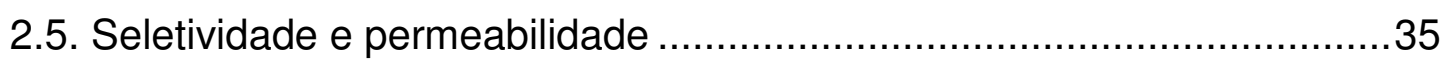

2.5.1. Modelo de resistência durante a filtração tangencial ....................36

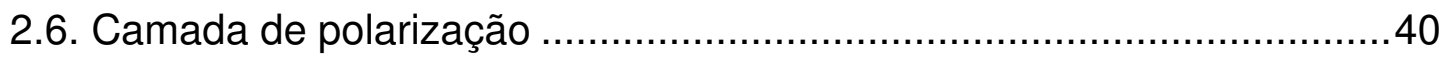

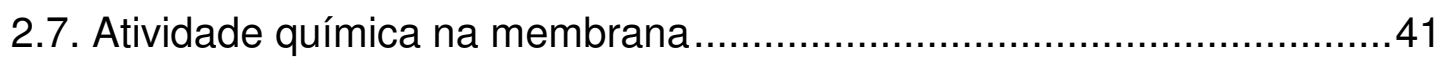

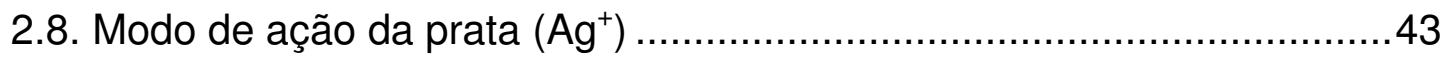

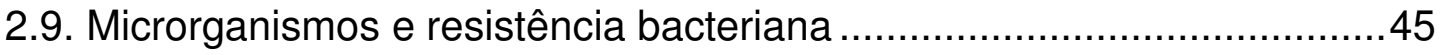

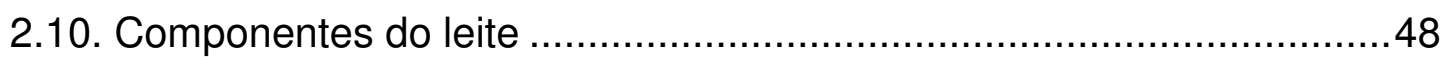

2.10.1. Microrganismos encontrados em leite....................................52

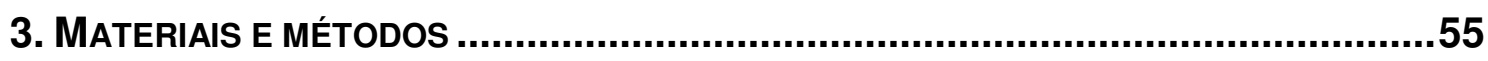

3.1. Seleção das estruturas microporosas ...................................................55 
3.2. Preparo, impregnação da solução de citrato de prata e posterior sinterização de impregnação das estruturas cerâmicas impregnadas ...........57

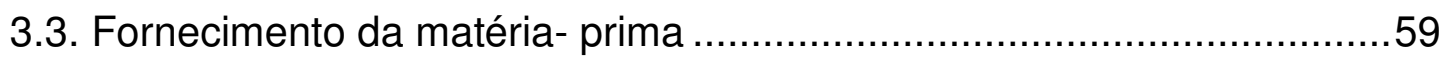

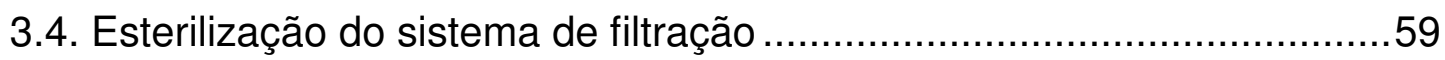

3.5. Microfiltração do soro de leite de búfala...............................................63

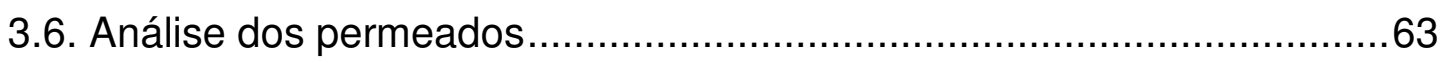

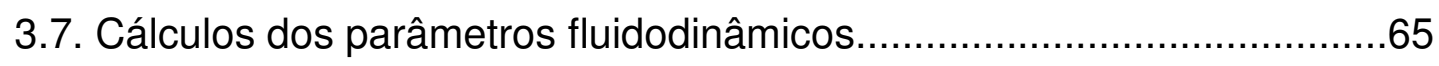

3.7.1. Cálculo da vazão transmembrana "J".........................................66

3.7.2. Cálculo do número de Reynolds "Re".......................................66

3.7.3. Cálculo da resistência à formação da camada de polarização "RC". .68

4. Resultados e discussões .70

4.1. Análises físicas para caracterização dos tubos cerâmicos microporosos .70

4.2. Análise da vazão transmembrana "J" (L/h. $\left.\mathrm{m}^{2}\right)$ durante o processamento 75

4.3. Análise do fluxo transmembrana $\left(\mathrm{L} / \mathrm{h} \cdot \mathrm{m}^{2}\right)$ em função da pressão

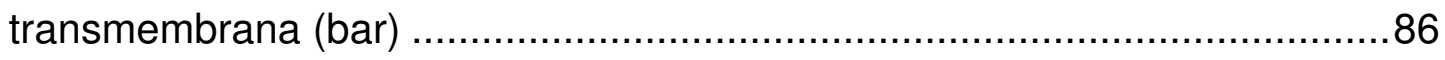
4.4. Vazão transmembrana (L/h. $\left.\mathrm{m}^{2}\right)$ em função do número de Reynolds "Re" .95

4.5. Análise do modelo de resistência para o processo com estruturas microporosas.

4.6. Análise microbiológica dos permeados nos processos de microfiltração 104

5. CONCLUSÕES E SUGESTÕES 112

5.1. Conclusões 112

5.2. Sugestões 114

REFERÊNCIAS BIBLIOGRÁFICAS 115

ANEXO A 124

ANEXO B 136

ANEXO C 140 
Figura 1 - Representação da microfiltração tangencial

Figura 2 - Esquema do mecanismo (gradiente de pressão e fluxo de filtração) de transporte da célula bacteriana através da membrana de microfiltração (adaptada por SUCHECKA, BIERNACKA e PIATKIEWICZ, 2003). 26

Figura 3 - Comportamento da espessura da camada de polarização e fluxo específico do filtrado ao longo da operação, na filtração estática (a) e tangencial (b).

Figura 4 - Espectro de filtração segundo o tamanho das partículas 33

Figura 5 - Mecanismos envolvidos na polarização de membranas. 40

Figura 6 - Célula bacteriana de Escherichia coli. 54

Figura 7 - Diagrama das fases da metodologia experimental 55

Figura 8 - (a) tubo microporoso fabricado através da técnica de extrusão (Tecnologia nacional - LTC); (b) tubo microporoso fabricado através da técnica de colagem (Tecnologia Nacional CETEBRA/TECNICER); (c) membrana comercial do tipo multi-canais (Tecnologia Alemã).

Figura 9 - Reação química do preparo de Citrato Metálico 58

Figura 10 (a) e (b) - Fotos dos sistemas de filtração (bancada experimental) utilizados na experimentação.

Figura 11 - Objetos utilizados na filtração do permeado para análise microbiológica .64

Figura 12 - Membrana filtrante com unidades formadoras de colônias (UFC) de diferentes bactérias (a); membrana filtrante com unidades formadoras de colônias em saturação (b) 65

Figura 13 - Determinação do diâmetro médio dos poros do tubo cerâmico de alumina impregnado com citrato de prata e sinterizado a $1450{ }^{\circ} \mathrm{C} . .71$

Figura 14 - Determinação do diâmetro médio dos poros do tubo cerâmico de 
alumina sem a impregnação do citrato de prata e sinterizado a 1400 $\stackrel{\circ}{ } \mathrm{C}$.

Figura 15- Distribuição dos principais componentes do tubo sinterizado à $1450^{\circ} \mathrm{C}$

Figura 16- Mapeamento através da Microscopia Eletrônica de Varredura (MEV) mostrando a presença de alumina $\left(\mathrm{Al}_{2} \mathrm{O}_{3}\right)$ e prata $(\mathrm{Ag})$ no tubo cerâmico de $0,5 \mu \mathrm{m}$ de tamanho médio de poros 72

Figura 17 - (a)Imagem da morfologia do tubo cerâmico mono-poroso sinterizado à $1450^{\circ} \mathrm{C}$ e impregnado com prata; (b) Mapeamento através da Microscopia Eletrônica de Varredura (MEV) mostrando a presença de prata $(\mathrm{Ag})$ no tubo cerâmico de $0,5 \mu \mathrm{m}$ de tamanho médio de poros.

Figura 18 - Imagens da morfologia do tubo cerâmico mono-camada sinterizado a $1450^{\circ} \mathrm{C}$ e impregnado com prata (a) e imagem da morfologia de um tubo cerâmico do tipo bicamada sinterizado a 1400ํㅡ (b)........74

Figura 19 - Imagem da morfologia da membrana comercial de tamanho nominal de poro igual a 1,2 $\mu \mathrm{m}$, produzida por Microscopia Eletrônica de Varredura (MEV) (a); Imagem da camada microporosa de interface com a membrana de $1,2 \mu \mathrm{m}(\mathrm{b})$. .74

Figura 20- Gráfico da vazão transmembrana (L/h.m²)em função do tempo para o processo de microfiltração tangencial com membrana comercial de $0,8 \mu \mathrm{m}$ de tamanho médio dos poros; 190mm de comprimento; 5,6mm de diâmetro interno, sem impregnação de prata e escoamento turbulento com $R e \approx 30000$ (a) e com impregnação de prata em escoamento turbulento com $R e \approx 30000$ (b), $R e \approx 27000$ (c) e $\mathrm{Re} \approx 22000$ (d). .76

Figura 21 - Gráfico da vazão transmembrana (L/h.m²) em função do tempo para o processo de microfiltração tangencial com membrana comercial sem impregnação de prata, com 1,2 $\mu \mathrm{m}$ de tamanho médio dos poros; $400 \mathrm{~mm}$ de comprimento; $6,0 \mathrm{~mm}$ de diâmetro interno em escoamento de transição de respectivamente $\mathrm{Re} \approx 4000$ (a), $\mathrm{Re} \approx 3500$ (b) e $\operatorname{Re} \approx 3000$ (c) .78

Figura 22 - Gráfico da vazão transmembrana $\left(L / h . m^{2}\right)$ em função do tempo 
para o processo de microfiltração tangencial com membrana comercial com a primeira impregnação de prata, com $1,2 \mu \mathrm{m}$ de tamanho médio dos poros; $200 \mathrm{~mm}$ de comprimento; $6,0 \mathrm{~mm}$ de diâmetro interno em escoamento turbulento de respectivamente $R e \approx 4000$ (a), $R e \approx 3500$ (b) e $R e \approx 3000$ (c)

Figura 23- Gráfico da vazão transmembrana (L/h.m²) em função do tempo para o processo de microfiltração tangencial com membrana comercial com a segunda impregnação de prata, com 1,2 $\mu \mathrm{m}$ de tamanho médio dos poros; 200mm de comprimento; 6,0 $\mathrm{mm}$ de diâmetro interno em escoamento de transição de respectivamente $R e \approx 4000$ (a), $\operatorname{Re} \approx 3500$ (b) e $R e \approx 3000$ (c). .82

Figura 24- Gráfico da vazão transmembrana (L/h.m²) em função do tempo para o processo de microfiltração tangencial com tubo cerâmico sem impregnação de prata, com 0,4 $\mu$ m de tamanho médio dos poros; $170 \mathrm{~mm}$ de comprimento; 7,0mm de diâmetro interno em escoamento turbulento de respectivamente $R e \approx 25000$ (a), $R e \approx 20000$ (b) e $\mathrm{Re} \approx 17000$ (c) 84

Figura 25- Gráfico da vazão transmembrana (L/h.m²) em função do tempo para o processo de microfiltração tangencial com tubo cerâmico sem impregnação de prata, com $0,5 \mu \mathrm{m}$ de tamanho médio dos poros; $190 \mathrm{~mm}$ de comprimento; 8,0mm de diâmetro interno em escoamento turbulento de respectivamente $R e \approx 21000$ (a), $R e \approx 18000$ (b) e $\mathrm{Re} \approx 15000$ (c). 85

Figura 26- Gráfico da vazão transmembrana (L/h.m²) em função da variação da pressão para o processo de microfiltração tangencial com membrana comercial $(0,8 \mu \mathrm{m}$ de tamanho médio dos poros; $190 \mathrm{~mm}$ de comprimento; 5,6 de diâmetro interno) sem impregnação de prata e escoamento turbulento $\operatorname{Re} \approx 30000$ (a) e com prata $R e \approx 30000$ (b), $\mathrm{Re} \approx 25000$ (c) e $\mathrm{Re} \approx 20000$ (d).

Figura 27- Gráfico da vazão transmembrana (L/h.m²) em função da variação da pressão para o processo de microfiltração tangencial com membrana comercial sem impregnação de prata, com $1,2 \mu \mathrm{m}$ de tamanho médio dos poros; 400mm de comprimento; 6,0mm de diâmetro interno em escoamento de transição de respectivamente $R e \approx 4000$ (a), $R e \approx 3500$ (b) e $R e \approx 3000$ (c); legenda das figuras 27 a, 
b e c (d)

Figura 28- Gráfico da vazão transmembrana (L/h.m²) em função da variação da pressão para o processo de microfiltração tangencial com membrana comercial com a primeira impregnação de prata, com $1,2 \mu \mathrm{m}$ de tamanho médio dos poros; $200 \mathrm{~mm}$ de comprimento; $6,0 \mathrm{~mm}$ de diâmetro interno em escoamento turbulento de respectivamente $R e \approx 4000$ (a), $R e \approx 3500$ (b) e $R e \approx 3000$ (c); legenda das figuras $28 \mathrm{a}$, b e c (d).

Figura 29- Gráfico da vazão transmembrana (L/h.m²) em função da variação da pressão para o processo de microfiltração tangencial com membrana comercial com a segunda impregnação de prata, com $1,2 \mu \mathrm{m}$ de tamanho médio dos poros; $200 \mathrm{~mm}$ de comprimento; $6,0 \mathrm{~mm}$ de diâmetro interno em escoamento turbulento de respectivamente $\operatorname{Re} \approx 4000$ (a), $\operatorname{Re} \approx 3500$ (b) e $\operatorname{Re} \approx 3000$ (c). ..........91

Figura 30- Gráfico da vazão transmembrana (L/h. $\left.\mathrm{m}^{2}\right)$ em função da variação da pressão para o processo de microfiltração tangencial com tubo cerâmico sem impregnação de prata, com 0,4 $\mu \mathrm{m}$ de tamanho médio dos poros; 170mm de comprimento; 7,0mm de diâmetro interno em escoamento turbulento de respectivamente $\mathrm{Re} \approx 25000$ (a), $\mathrm{Re} \approx 20000$ (b) e $\mathrm{Re} \approx 17000$ (c) ..........................................92

Figura 31- Gráfico da vazão transmembrana (L/h. $\left.\mathrm{m}^{2}\right)$ em função da variação da pressão para o processo de microfiltração tangencial com tubo cerâmico, sem impregnação de prata, com 0,5 $\mu$ m de tamanho médio dos poros; 190mm de comprimento; 8,0mm de diâmetro interno em escoamento turbulento de respectivamente $R e \approx 21000$ (a), $\mathrm{Re} \approx 18000$ (b) e $\mathrm{Re} \approx 15000$ (c)

Figura 32- Gráfico da vazão transmembrana (L/h.m²) no final do processo (50 minutos) em função do número de Reynolds para o processo de microfiltração tangencial com membrana comercial, com impregnação de prata, com $0,8 \mu \mathrm{m}$ de tamanho médio dos poros; $190 \mathrm{~mm}$ de comprimento; 5,6 de diâmetro interno em escoamento turbulento.

Figura 33 - Gráfico da vazão transmembrana $\left(\mathrm{L} / \mathrm{h} \cdot \mathrm{m}^{2}\right)$ do final do processo (30minutos) em função do número de Reynolds para o processo de 
microfiltração tangencial com membrana comercial, sem impregnação de prata, com uma e duas impreganações, com $1,2 \mu \mathrm{m}$ de tamanho médio dos poros; 400mm de comprimento; 6,0mm de diâmetro interno em escoamento turbulento, a 1, 2 e 3 bar. 96

Figura 34- Gráfico da vazão transmembrana (L/h.m ${ }^{2}$ ) no final do processo (50 minutos) em função do número de Reynolds para o processo de microfiltração tangencial com tubo cerâmico sem impregnação de prata, com 0,4 $\mu \mathrm{m}$ de tamanho médio dos poros; $170 \mathrm{~mm}$ de comprimento; 7,0mm de diâmetro interno em escoamento turbulento e a 1,2, 3 e 4 bar. .97

Figura 35 - Gráfico da vazão transmembrana (L/h.m² ${ }^{2}$ no final do processo (50 minutos) em função do número de Reynolds para o processo de microfiltração tangencial com tubo cerâmico sem impregnação de

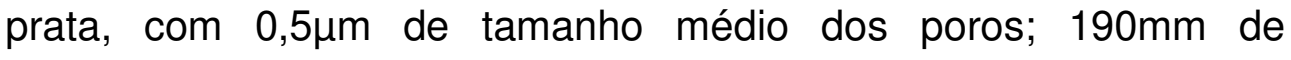
comprimento; 8,0mm de diâmetro interno em escoamento turbulento e a 1,2, 3 e 4 bar. .97

Figura 36 - Resistência à formação da camada de polarização " $R_{C}$ " da membrana comercial de tamanho nominal de poro igual a $0,8 \mu \mathrm{m}$ para os regimes de escoamentos turbulentos. .99

Figura 37- Resistência à formação da camada de polarização " $\mathrm{R}_{\mathrm{C}}$ " da membrana comercial de tamanho nominal de poro igual $1,2 \mu \mathrm{m}$, sem impregnação de prata, para os regimes de escoamento de transição. 100

Figura 38- Resistência à formação da camada de polarização " $\mathrm{R}_{\mathrm{C}}$ " da membrana comercial de tamanho nominal de poro igual $1,2 \mu \mathrm{m}$, com a primeira impregnação de prata, para os regimes de escoamentos de transição. 101

Figura 39 - Resistência à formação da camada de polarização " $\mathrm{R}_{\mathrm{C}}$ " da membrana comercial de tamanho nominal de poro igual $1,2 \mu \mathrm{m}$, com a segunda impregnação de prata, para os regimes de escoamentos de transição. 102

Figura 40 - Resistência à formação da camada de polarização " $\mathrm{R}_{\mathrm{C}}$ " do tubo cerâmico $0,4 \mu \mathrm{m}$ para os regimes de escoamentos turbulentos..... 103 
Figura 41 - Resistência à formação da camada de polarização " $\mathrm{R}_{\mathrm{C}}$ " do tubo cerâmico $0,5 \mu \mathrm{m}$ para os regimes de escoamentos turbulentos....103 
Tabela 1 - Componentes do leite de búfala e do leite de vaca

Tabela 2 - Unidades formadoras de colônia por grama (UFC/g) de bactérias do grupo coliforme fecal (E. coli) presentes nos permeados correspondentes a 15 minutos de filtração para a membrana comercial de $0,8 \mu \mathrm{m}$ de tamanho médio de poros. 105

Tabela 3 - Unidades formadoras de colônia por grama (UFC/g) de bactérias do grupo coliforme fecal (E. coli) presentes nos permeados correspondentes a 45 minutos de filtração para a membrana comercial de $0,8 \mu \mathrm{m}$ de tamanho médio de poros. 106

Tabela 4 - Unidades formadoras de colônia por grama (UFC/g) de bactérias do grupo coliforme fecal (E. coli) presentes nos permeados correspondentes a 15 minutos de filtração para a membrana comercial de $1,2 \mu \mathrm{m}$ de tamanho médio de poros. 107

Tabela 5 - Unidades formadoras de colônia por grama (UFC/g) de bactérias do grupo coliforme fecal (E. coli) presentes nos permeados correspondentes a 30 minutos de filtração para a membrana comercial de 1,2 $\mu \mathrm{m}$ de tamanho médio de poros. 108

Tabela 6 - Unidades formadoras de colônia por grama (UFC/g) de bactérias do grupo coliforme fecal ( $E$. coli) presentes nos permeados correspondentes a 25 minutos de filtração para o tubo cerâmico de $0,4 \mu \mathrm{m}$ de tamanho médio de poros, sem a impregnação de prata metálica. 109

Tabela 7 - Unidades formadoras de colônia por grama (UFC/g) de bactérias do grupo coliforme fecal (E. coli) presentes nos permeados correspondentes a 50 minutos de filtração para o tubo cerâmico de $0,4 \mu \mathrm{m}$ de tamanho médio de poros, sem a impregnação de prata metálica. 109

Tabela 8 - Unidades formadoras de colônia por grama (UFC/g) presentes nos permeados correspondentes a 15 minutos de filtração para o tubo cerâmico de $0,5 \mu \mathrm{m}$ de tamanho médio de poros, sem a impregnação de prata metálica. 
Tabela 9 - Unidades formadoras de colônia por grama (UFC/g) de bactérias do grupo coliforme fecal (E. coli) presentes nos permeados correspondentes a 45 minutos de filtração para o tubo cerâmico de $0,5 \mu \mathrm{m}$ de tamanho médio de poros, sem a impregnação de prata metálica. 
Anexo A - Vazão Transmembrana "J". 123

Anexo B - Resistência da membrana "Rm", Resistência total "RT" e Resistência à formação da camada de polarização "RC". 136

Anexo

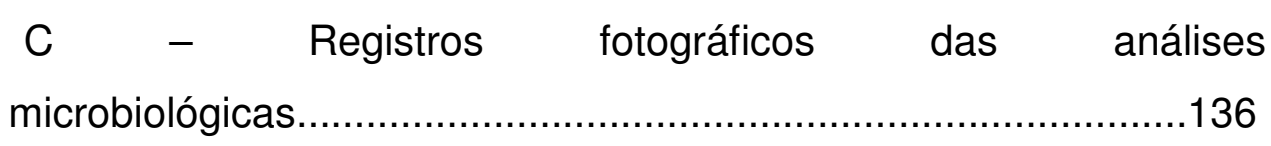




\section{Símbolos GeRAIS:}

\begin{tabular}{|c|c|c|}
\hline$A g$ & - Prata & \\
\hline $\mathrm{Al}_{2} \mathrm{O}_{3}$ & - Alumina & \\
\hline$B$ & - Permeabilidade de depósito & \\
\hline $\mathrm{CO}_{2}$ & - Dióxido de carbono & \\
\hline $\mathrm{C}_{6} \mathrm{H}_{8} \mathrm{O}_{6}$ & - Ácido cítrico & \\
\hline$D$ & diâmetro & [m] \\
\hline$D N A$ & - Ácido desoxirribonucléico & \\
\hline$d_{P}$ & - Diâmetro dos poros & [m] \\
\hline$D Q O$ & Demanda química de oxigênio & {$\left[\mathrm{mg} / \mathrm{LO}_{2}\right]$} \\
\hline$e p_{g}$ & Superfície da camada de polarização & {$[\mathrm{m}]$} \\
\hline$H$ & hidrogênio & \\
\hline $\mathrm{HNO}_{3}$ & Ácido nítrico & \\
\hline $\mathrm{H}_{2} \mathrm{SO}_{4}$ & - Ácido sulfúrico & \\
\hline$J$ & - fluxo transmembrana & {$\left[\mathrm{L} /\left(\mathrm{h} \cdot \mathrm{m}^{2}\right)\right]$} \\
\hline$L$ & - comprimento do tubo & [m] \\
\hline$L /\left(h \cdot m^{2}\right)$ & - Litro por hora vezes metro ao quadrado & \\
\hline M & Molar & \\
\hline
\end{tabular}




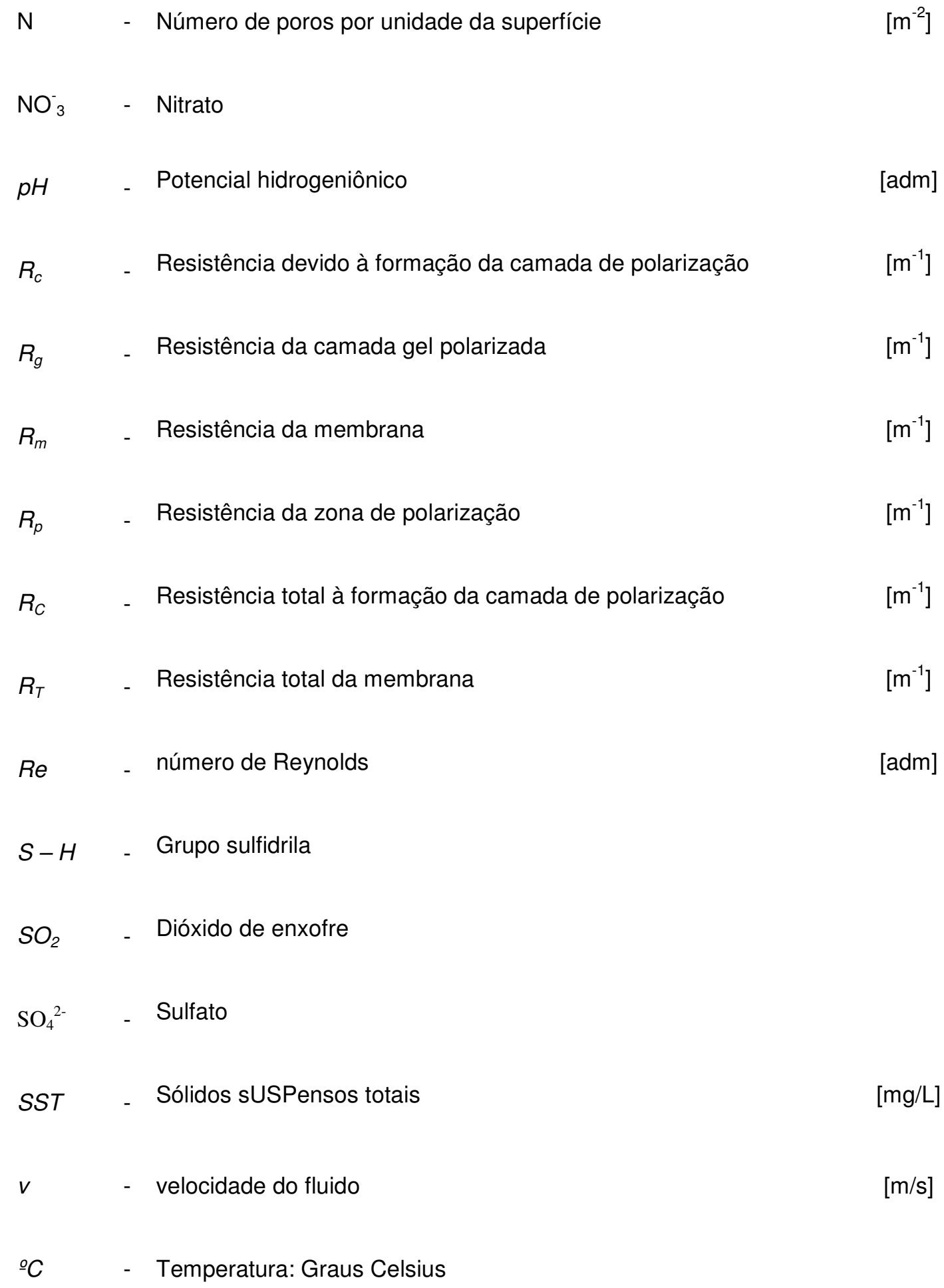




\section{SímBolos GREGOS}

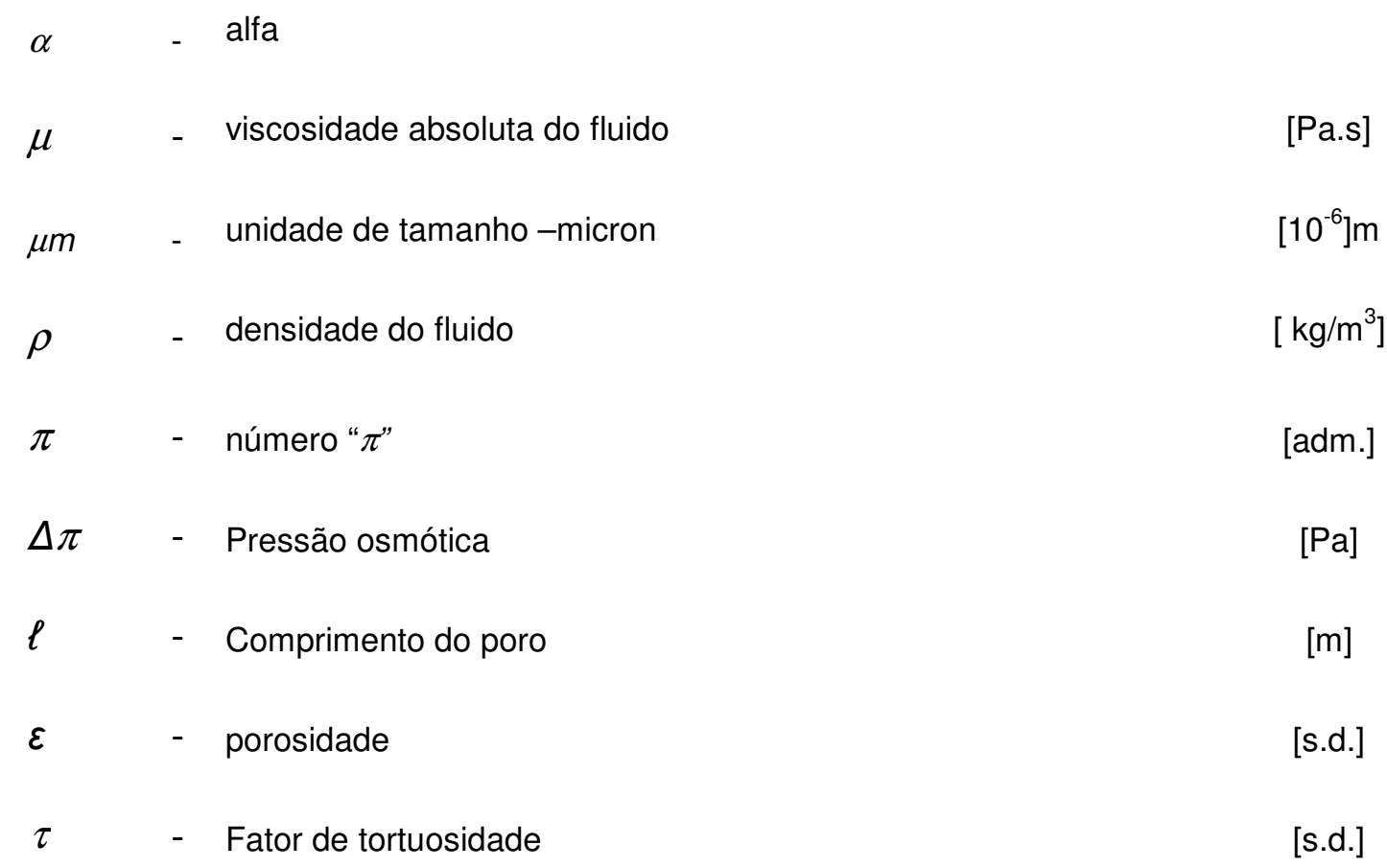

\section{AbreViaturas e Siglas}
ESMST - European Society of Membrane Science and Technology
IREPOLIA - Institute de Recherche sur Pollution Industrille et Agricole
LIEC - Laboratório Interdisciplinar de Eletroquímica e Cerâmica
MEV - Microscopia eletrônica de varredura (abreviação)
MF $\quad-$ Microfiltração
MFT - Microfiltração tangencial
$\mathrm{NADH} \quad-\quad$ Nicotinamida adenina dinucleotídeo
org. - organismos

org $/ \mathrm{cm}^{2} \quad$ - Organismo por centímetro quadrado de área superficial da membrana 
UCF - Unidade de coliforme fecal

UV - Ultra-violeta 
HANEDA, Renata Natsumi (2006). Investigação do desempenho de diferentes estruturas micro-porosas tubulares na retenção de bactérias em suspensão por microfiltração tangencial. Dissertação (Mestrado). Escola de Engenharia de São Carlos, Universidade de São Paulo, São Carlos.

Neste trabalho são apresentados resultados experimentais do processo de filtração tangencial de uma suspensão in natura (soro de leite) aplicada na retenção de bactérias do grupo coliforme. No estudo do processo de separação utilizaram-se tubos microporosos de $\alpha$-alumina $\left(\mathrm{Al}_{2} \mathrm{O}_{3}\right)$ e membranas

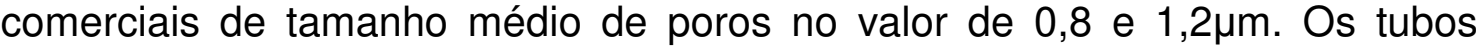
microporosos cerâmicos foram sinterizados à temperatura entre 1400 e $1450^{\circ} \mathrm{C}$, os quais foram caracterizados pela técnica de porosimetria por intrusão de mercúrio, constatando o tamanho médio de poros de 0,3 a 0,5 $\mu$ m. Após a sinterização, os tubos cerâmicos foram sujeitos à impregnação com citrato de prata (material bactericida). As membranas comerciais também passaram pelo mesmo processo de impregnação. Com o uso da técnica de microscopia eletrônica de varredura (MEV) foi realizada uma caracterização da morfologia e da composição dos meios microporosos. Ensaios experimentais do processo de microfiltração foram realizados com soro de leite, com o objetivo de estudar a influência de parâmetros fluidodinâmicos tais como: número de Reynolds e pressão transmembrana, além de analisar a retenção da bactéria, Escherichia coli, em regime de escoamento para Reynolds entre 2700 e 32000 e pressões transmembrana entre 1 e 4 bar. $O$ permeado foi analisado seguindo normas da 20ํㅡ. Edição dos Métodos Padrões para Análise de Água e Esgoto, e todos os experimentos seguiram padrões de segurança para minimizar a possibilidade de contaminação do meio junto à análise do material filtrado. A manutenção fisiológica das bactérias foi controlada com os parâmetros de $\mathrm{pH}$ e temperatura, respectivamente mantidos entre 6 e 7,0 e de $25-30^{\circ} \mathrm{C} \pm 1 \stackrel{\circ}{\circ} \mathrm{C}$. Nestas condições de escoamento, da solução e do meio filtrante, o processo foi considerado satisfatório com vazões transmembrana entre $10 \mathrm{~L} /\left(\mathrm{h} \cdot \mathrm{m}^{2}\right)$ e $120 \mathrm{~L} /\left(\mathrm{h} \cdot \mathrm{m}^{2}\right)$.

Palavras-Chave: Escherichia coli; Microfiltração; Meio microporoso; Alumina; Prata; Soro de leite. 
HANEDA, Renata Natsumi (2006). Investigation of the performance of diferent micro-porous tubular structures in the retention of bacterias emulsion by crossflow microfiltration. Dissertação (Mestrado). Escola de Engenharia de São Carlos, Universidade de São Paulo, São Carlos.

This work reports experimental results of the crossflow microfiltration of emulsion (whey of milk) applied in the microrganism retention of the coliform group. In the study of the separation process were used micro-porous tubes of $\alpha$-alumina $\left(\mathrm{Al}_{2} \mathrm{O}_{3}\right)$ and commercial membranes of average size pores of 0,8 and $1,2 \mu \mathrm{m}$. The micro-porous tubes were sinterised with temperature between 1400 and $1450 \stackrel{\circ}{\circ} \mathrm{C}$ and after, were characterized by technique of porosimetry for mercury intrusion, verifing average size of pores between 0,3 and 0,5 $\mu \mathrm{m}$. After the sintering, the ceramic tubes were treated with a citrate of silver solution (bactericidal substance), and submitted to synthesis for removed the organic matters. The commercial membranes were also impregnated by this process. With the scanning eletronic microscopy made the characterization of the morfology and micro-porous structures composition. Experimental tests of the crossflow microfiltration process were performed with whey of milk, with objective to study the influence of fluid dynamics parameters (Reynolds number and flux transmembrane) and to analyse the bacteria retention in turbulent regime, having "Re" between 2700 and 32000, transmembrane pressure (enters 1 to $4 \mathrm{bar}$ ) and transmembrane flux between 0,5 and $300 \mathrm{~L} / \mathrm{h} \cdot \mathrm{m}^{2}$. The permeate was analysed by the 20. Examination of Water, and all the experiments followed standards of security to restrict the possibility of contamination of the permeated and the atmosphere. The physiology of the bacteria was controlled by parameters of $\mathrm{pH}$ and temperature, respectively keeped between 6 and 7,0 and of $25-30^{\circ} \mathrm{C} \pm 1{ }^{\circ} \mathrm{C}$. In the conditions of flow, of the solution and system flow, the retention was considerated satisfactory with transmembrane flux between $10 \mathrm{~L} /\left(\mathrm{h} . \mathrm{m}^{2}\right)$ and $120 \mathrm{~L} /\left(\right.$ h. $\left.\mathrm{m}^{2}\right)$.

Keywords: Escherichia coli; microfiltration; micro-porous structure; Alumina; Silver; Whey of milk . 


\section{Capítulo 1}

\section{INTRODUÇÃO E OBJETIVOS}

\subsection{INTRODUÇÃO}

Microfiltração com membranas é um processo de relevância que vem atualmente se destacando no vasto mercado da engenharia de processos. $O$ processo requer o uso de módulos filtrantes compostos por material cerâmico ou polimérico. Em aplicações tecnológicas, a filtração tangencial contém 0 espectro de separação na faixa de microfiltração, que permite a separação de partículas tipo bactérias, proteínas, emulsões, dentre outras misturas (RIPPERGER e ALTMANN, 2002). Áreas da engenharia de processos, que incluem a filtração tangencial (micro e ultrafiltração), têm demonstrado potencial à eficaz remoção de componentes em misturas sólido-líquido, líquidolíquido e gás-sólido. Classifica-se como micro e ultrafiltração, respectivamente os processos de filtração tangencial, eficazes, na separação de partículas entre 0.01 e $5 \mu \mathrm{m}$, que incluem colóides, emulsões, proteínas (QUEIROZ, 2004) e contaminantes microbiológicos como bactérias (VIDAL, 2001).

Os processos de micro e ultrafiltração também têm grande importância para a indústria química, com o objetivo de purificar a água. Na microfiltração utilizam-se filtros de profundidade, compostos principalmente de fibras de celulose ou sintéticas, bem como membranas cerâmicas microporosas. Na ultrafiltração com membranas micro-porosas, consegue-se a separação de partículas da ordem de 1,0 a 100,0 nano-microns com faixa de pressão transmembrana entre 1,0 e 5,0 bar. Um ultra-filtro, também chamado de filtro molecular, é constituído por duas membranas seletivas, capaz de reter com eficiência; moléculas dissolvidas, material coloidal, microrganismos e 
pirogênios ( SCOTT, 1995) .

Zeman \& Zydney (1996) também ressaltam a importância do uso da microfiltração com membranas para retenção microbiana nas áreas de ciências biológicas, da saúde e alimentícias. Isto porque há uma relação direta entre o processo de microfiltração com o objeto de estudo destas áreas, conhecido por filtros de líquidos esterilizados. Um filtro esterilizado é definido como um não libertador de fibra que produzirá um efluente estéril quando contaminado com um microrganismo específico em concentração mínima de $10^{7} \mathrm{org} / \mathrm{cm}^{2}$ de área superficial da membrana.

Em fábricas de tintas e na indústria têxtil também há uma preocupação com a descontaminação de suas águas residuárias. DEY, HASHIM, HASAN, GUPTA (2004) relatam que o maior obstáculo associado com a reciclagem de água residual proveniente da fabricação de tintas é a contaminação microbiológica e a deterioração relacionada à qualidade do processo e a validade do produto. E portanto, devido a essa contaminação e a essa deterioração, a reciclagem de águas residuais oriundas deste tipo de processo não é uma prática muito utilizada.

A aplicação do processo de microfiltração tangencial com a água residual de uma fábrica de tintas da Malásia gerou uma redução de $55 \%$ da água de consumo. No projeto de pesquisa de AL-MALACK (2003) investigaram-se aspectos tecnológicos e econômicos do processo de microfiltração tangencial e do processo de filtração através de filtro de areia, objetivando-se a melhoria na qualidade do tratamento de águas residuárias. Os resultados mostraram que a filtração tangencial, além de apresentar menos problemas operacionais, gera um permeado com qualidade confiável. Entretanto, ele concluiu que o custo da lenta filtração através de filtro de areia é menor quando comparado com os demais sistemas de microfiltração. Quando se substituiu a microfiltração tangencial pelo vagaroso sistema de filtros de areia constatou-se uma redução de $50 \%$ do custo do processo. Porém, este custo adicional da microfiltração pode estar relacionado dentre outros fatores, à origem da tecnologia de membranas para microfiltração, ou seja, as membranas normalmente são de origem estrangeira, significando um aumento 
no custo da pesquisa e implantação do sistema.

Nesta dissertação de mestrado foi estudado o processo de microfiltração de uma suspensão (soro do leite), também composta de microrganismos do grupo coliforme. Investigou-se o desempenho de diferentes estruturas microporosas tubulares cerâmicas de origem nacional e importada, quanto à retenção de microrganismos. Os meios microporosos, impregnados quimicamente, também foram avaliados quanto à ação bactericida da prata. 


\subsection{OBjetivos}

O objetivo geral desta dissertação de mestrado foi o estudo do desempenho de diferentes estruturas microporosas tubulares cerâmicas em processamento por microfiltração, na retenção de microrganismos, presentes em uma suspensão in natura (soro do leite).

Os objetivos específicos deste trabalho são:

- Investigar o potencial de retenção de microrganismos do grupo coliforme fecal (bactéria Escherichia coli), em suspensão residuária (soro de leite), por meio do processo de microfiltração tangencial com estruturas microporosas tubulares e membranas comerciais;

- Avaliar a retenção de bactérias com os materiais tubulares microporosos, impregnados com solução de citrato de prata;

- Avaliar a influência de parâmetros fundamentais e fluidodinâmicos tais como: a pressão transmembrana e o regime de escoamento com variação do número de Reynolds.

- Comparar o comportamento de uma membrana comercial (origem alemã) com tubos cerâmicos tubulares fabricados por técnica de extrusão e de colagem. 


\section{Capítulo 2}

\section{REVISÃO BIBLIOGRÁFICA}

A crescente preocupação e investimento com reuso da água está associada ao aumento constante do abastecimento doméstico, industrial e agrícola. Os processos capazes de transformar uma água residuária a uma água de reuso, também devem ser avaliados na cadeia de filtração, principalmente quanto a seu custo e impacto ambiental.

Dentro desse contexto, a filtração tangencial é inclusa, e apresenta-se efetivamente instalada industrialmente conforme dados da literatura (Zeman \& Zydney, 1996).

O processo com uso de membranas cerâmicas possui aspectos favoráveis, como por exemplo, a limpeza das membranas pode ocorrer sem produtos químicos, via queima de matéria orgânica, podendo ainda, o material filtrante e cerâmico ser reciclado.

$\mathrm{Na}$ seqüência são comentados aspectos particulares da literatura relacionado ao uso e aplicações do processo de microfiltração tangencial.

\subsection{Contaminantes da ÁGua}

Há vários tipos de contaminantes da água, como por exemplo, resíduos sólidos, líquidos ou gasosos, sólidos em suspensão, matéria tóxica, lixo radioativo e microrganismos patogênicos.

E estes ainda podem ser classificados como: 
- Inorgânicos: sais inorgânicos dissociados em água sob a forma de íons. Como exemplo, o cálcio, o ferro e o manganês, que em teores elevados, prejudicam os processos industriais, bem como na irrigação agrícola, principalmente os íons ferro e manganês, e altas concentrações de sólidos solúveis, obstruem tubulações, reduzindo a área de condução da água, promovendo a perda de carga do sistema.

- Orgânicos: compostos provenientes da atividade humana doméstica (detergentes, gorduras, lixo doméstico), da atividade agrícola no uso de fertilizantes, pesticidas, do despejo industrial, dos esgotos não tratados, do próprio lixo urbano não coletado, que é levado pela correnteza da água proveniente das chuvas etc, atingindo rios e lagos. Estes contaminantes podem interferir nos processos químicos, na estabilidade de formulações de compostos químicos, além de tornar os equipamentos industriais inoperantes.

- Sólidos em suspensão: são pequenas partículas contaminantes insolúveis, visível somente ao microscópio, que estão na superfície das águas residuárias. Podem ter origem orgânica e inorgânica, como por exemplo, a maior parte de produtos em decomposição, resto de alimentos, papel, madeira, e outros.

- Materiais particulados: abrange uma série de materiais de diferentes composições e morfologia, como sílica, poeira, ferro e produtos de abrasão, minerais não solúveis, compostos orgânicos de alto peso molecular e material coloidal.

- Microrganismos: a água, como possível portador de microrganismos patogênicos, pode por em perigo a saúde e a vida da população que a consome. Os germes patogênicos que se propagam com mais freqüência pela água são os que causam infecções intestinais, tais como, febre tifóide, disenterias e cólera. Estes microrganismos se encontram nas fezes e na urina das pessoas infectadas, e quando são eliminados podem contaminar águas que serão utilizadas como água para beber. A água condensada nas nuvens, que se precipita em forma de neve, granizo e chuva, constitui a água atmosférica. A flora microbiana que esta água contém, provem do ar, 
que está contaminado sendo que a água ao descer arrasta as partículas de pó em suspensão que contém os microrganismos aderentes às mesmas (GAIGNET, 2001).

KOLEGA et al. (1991) pesquisaram a utilização da microfiltração para desinfecção e clarificação de águas residuárias após tratamento primário e, também efluente de um sistema de lodos ativados. O emprego de um sistema de limpeza reduziu de maneira significativa os problemas de polarização das membranas. $O$ estudo mostrou que a microfiltração é eficaz para a eliminação de coliformes fecais, totais e streptococos. A eliminação de metais pesados, óleos e graxas foi significativa, e praticamente foi removida toda matéria em suspensão.

\subsection{Processo de MICROFILTRAÇÃo}

A microfiltração (MF) é um processo que utiliza o gradiente de pressão como força motriz, junto a uma superfície permeável (membrana) que visa a separação de partículas. As membranas utilizadas possuem microporos que

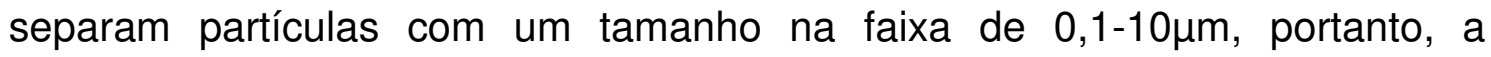
microfiltração está entre a ultrafiltração e a filtração convencional que não possui operação com membrana (QUEIROZ, 2004).

A microfiltração tangencial (Figura 1) ocorre tangencialmente a uma superfície permeável (membrana) e é usada para a produção de líquidos puros, para a concentração de sUSPensões, para recuperar produtos e para a regeneração de processos líquidos. A microfiltração se tornou um processo estabelecido para a separação de micropartículas, bactérias e emulsões. Freqüentemente uma concentração muito alta de uma mistura fluida pode ser alcançada, por isso a microfiltração tangencial é normalmente utilizada em combinação com outros processos de separação (RIPPERGER e ALTMANN, 2002). 


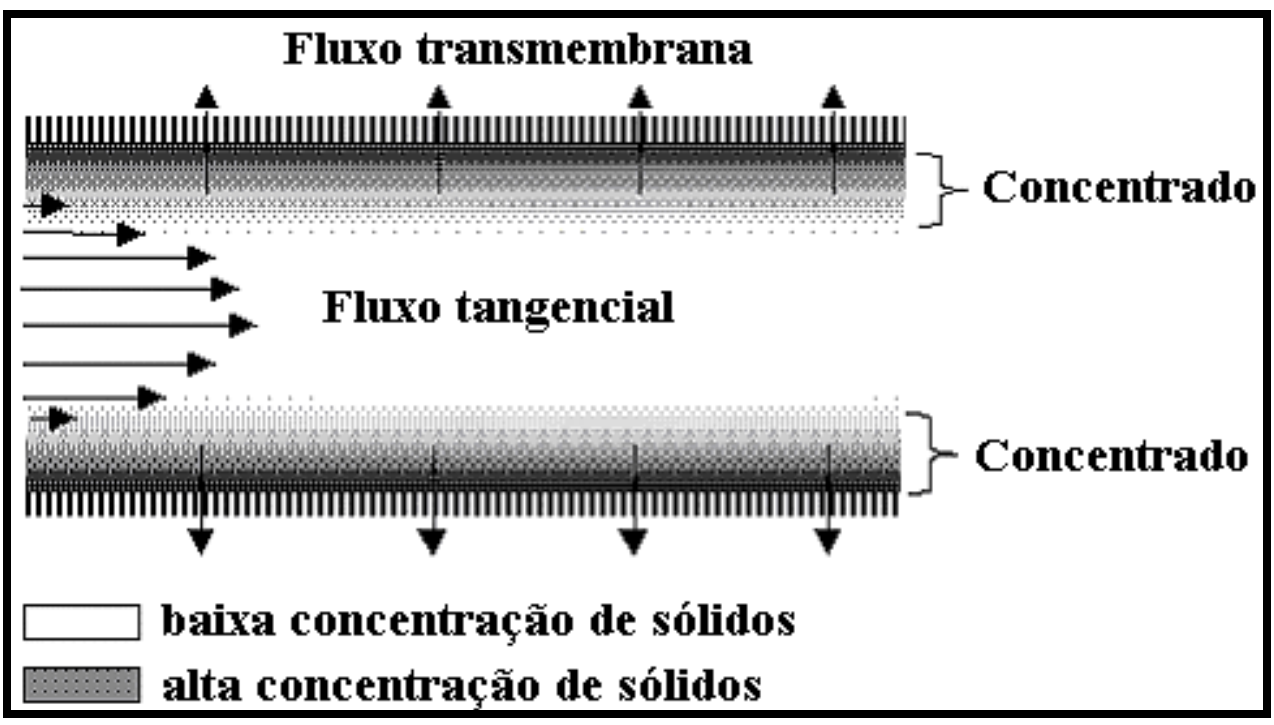

Figura 1 - Representação da microfiltração tangencial

KUNIKANE et al. (1995) apresentaram vários experimentos realizados para demonstrar a aplicabilidade da microfiltração e também da ultrafiltração para potabilização de águas provenientes de mananciais superficiais pouco poluídos. Os primeiros resultados foram satisfatórios quanto à eficiência do tratamento. Não houve grande diferença de resultado entre a microfiltração e a ultrafiltração, entretanto, quando se utilizou a microfiltração foi necessário prétratamento por coagulação para garantir uma melhor vazão do permeado.

Não são observadas diferenças significativas entre os processos de microfiltração e ultrafiltração, a não ser pelo maior diâmetro dos poros das membranas de microfiltração e da pressão menor, normalmente utilizada para se promover a separação e/ou concentração de macro-moléculas (LAPOLLI, 1998).

A separação com membranas está baseada no efeito peneira molecular e macromolecular, sendo limitado, principalmente à natureza de sua superfície. A estrutura dos microporos da membrana deveria ter uma estreita distribuição do tamanho do poro para assegurar a retenção quantitativa das partículas de um determinado tamanho e tipo. Outra característica importante é a alta porosidade das membranas que conduzem a elevadas taxas de filtração a pequenas diferenças de pressão (RIPPERGER e ALTMANN, 2002).

Nos processos de microfiltração e ultrafiltração, a membrana está sujeita a um gradiente de pressão para conduzir o solvente e as pequenas espécies 
através de seus poros, enquanto as moléculas maiores devem ser retidas. Assim, uma vazão de alimentação é dividida em duas, a vazão do concentrado que será enriquecido de macromoléculas retidas e a vazão de permeado que será deficiente ou isenta de macromoléculas (QUEIROZ, 2004).

VIDAL (2001) estudou a microfiltração tangencial como alternativa de pós-tratamento de efluente de reator anaeróbio de leito expandido alimentado com esgoto sanitário, gerando resultados positivos e promissores, nos quais pôde-se dizer que a técnica em questão é eficaz e que produz efluente que atende aos padrões de reuso na agricultura, para coliformes fecais e totais.

LI, FANE, COSTER e VIGNESWARAN (2003) estudaram o comportamento de deposição e remoção de bactérias sub-micron (SW8) através de observações diretas nas superfícies das membranas durante 0 processo de microfiltração.

GUERRA et al. (1997) analisaram a otimização de uma técnica de relavagem com água combinada com membranas assimétricas reversas, a fim de se evitar a obstrução e problemas de concentração por polarização, permitindo o uso de velocidade linear baixa e resultando em custos baixos de energia.

QUEIROZ (2004) obteve resultados satisfatórios ao utilizar o processo de microfiltração tangencial com membranas tubulares inorgânicas e tubos microporos na separação de misturas macromoleculares preparadas com os agentes polissacarídeos gomas Xantana e Guar em suspensão aquosa.

DEL COLLE (2005) estudou uma outra aplicação relevante no uso de membranas cerâmicas microporosas no processo de microfiltração tangencial. Em seu trabalho de pesquisa, a autora mostra retenção de até $99 \%$ da fase óleo no processo de desemulsificação de emulsões estáveis de água e óleo de girassol por filtração tangencial.

O processo de microfiltração também vêm sendo amplamente utilizado nos laticínios, uma vez que possui capacidade na remoção de bactérias e retenção de gordura e proteínas de soro de alto peso molecular, de pequenas proteínas de soro, nitrogênio não protéico (NPN), lactose e minerais de baixo 
peso molecular (GEAFILTRATION, 2006).

LANGLAIS et al. (1992) utilizaram a microfiltração como meio de desinfecção de um efluente após tratamento biológico. Os resultados confirmaram que a microfiltração à $0,2 \mu \mathrm{m}$ é uma barreira eficaz na remoção dos coliformes fecais. A redução média da turbidez chegou a 99\%, enquanto que as taxas de redução da DQO (Demanda química de oxigênio) variam de $31 \%$ a $72 \%$ em função do modo de filtração utilizado (frontal ou tangencial). As vazões médias foram de $75 \mathrm{~L} /\left(\mathrm{h} \cdot \mathrm{m}^{2}\right.$ ) (microfiltração frontal) e $82 \mathrm{~L} /\left(\mathrm{h} \cdot \mathrm{m}^{2}\right.$ ) (microfiltração tangencial).

A utilização de sistema de microfiltração $(0,2 \mu \mathrm{m})$ se mostrou eficaz para eliminação de coliformes totais, coliformes fecais e streptococos a partir de um efluente secundário de uma estação de tratamento de esgotos por lodos ativados. A vazão média foi de $200 \mathrm{~L} /\left(\mathrm{h} \cdot \mathrm{m}^{2}\right)$ para uma pressão aplicada de 1 bar. O efluente final obtido apresentou uma qualidade mais elevada se comparado com aqueles obtidos em tratamentos terciários convencionais (KOLEGA et al., 1989).

SUCHECKA, BIERNACKA e PIATKIEWICZ (2003) estudaram vários tipos de membranas para microfiltração, como a de polipropileno, diacetato de celulose (tamanho de poro igual a 0,2 $\mu \mathrm{m}$ ) e policarbonato (tamanho do poro igual a 0,4 $\mu \mathrm{m}$ ) para avaliar a capacidade de retenção de microrganismos. Trabalhou-se com sUSPensões de Pseudomonas diminuta e eritrócitos bovinos (EB) para fins experimentais como representantes de microrganismos. Baseando-se na microscopia e na avaliação microbiológica, demonstrou-se que células individuais de ambas as espécies podem atravessar uma membrana considerada normalmente como asséptica.

Outra interessante propriedade da retenção de microrganismos nas membranas de microfiltração é que as membranas são utilizadas como uma barreira microbiana que devem ser caracterizadas pelo tamanho máximo de poro, pelas células bacterianas que podem penetrar nos poros com tamanho de poro significativamente menor (Figura 2) e pela passagem de célula através dos pequenos poros, indicando que a membrana celular não pode ser esticada (LIGHTFOOD, 1974), demonstrando ser possível somente através da redução 
de volume da célula (SUCHECKA, BIERNACKA e PIATKIEWICZ, 2003).

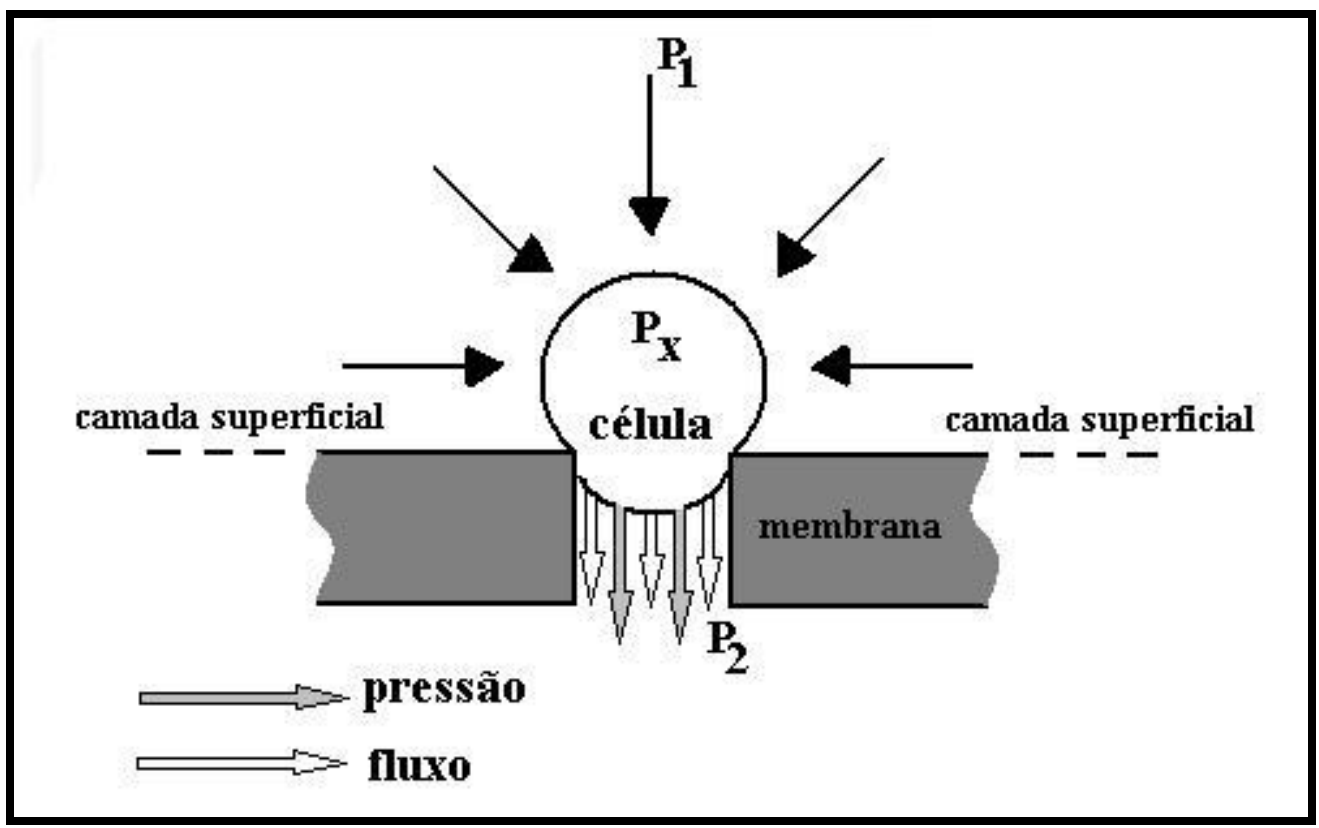

Figura 2 - Esquema do mecanismo (gradiente de pressão e fluxo de filtração) de transporte da célula bacteriana através da membrana de microfiltração (adaptada por SUCHECKA, BIERNACKA e PIATKIEWICZ, 2003).

BAILEY e MEAGHER (2000) desenvolveram o processo de filtração tangencial com membrana para separar proteína intracelular solúvel originárias de restos e de corpos inclusos presentes na recombinante célula lisada de Escherichia coli. Também se preocuparam em projetar membranas com diferenças químicas, tamanhos de poros e configurações para um alto fluxo permeável, transmissão protéica e recuperação do fluxo de água após a limpeza.

A microfiltração tangencial (MFT) é um processo que sofre sensíveis reduções devido à formação da camada de polarização. Entretanto, o processo possui vantagens em relação aos sistemas convencionais (filtração frontal), pois a polarização pode ser reduzida pela corrente paralela à membrana.

De acordo com Hugo Santos (1992), a espessura da camada de polarização (cake layer) numa filtração tangencial tem um comportamento diferente daquela que ocorre numa filtração frontal. A curva da espessura da torta de filtro na filtração tangencial atinge valores menores que o do fluxo específico do filtrado ao longo da operação, mesmo que estes valores aumentem até um patamar de estabilidade (Figura 3a). Na filtração estática, os 
valores atingidos pelo fluxo específico do filtrado diminuem ao longo da operação, enquanto a espessura da camada de polarização tem um comportamento inverso (Figura 3b).

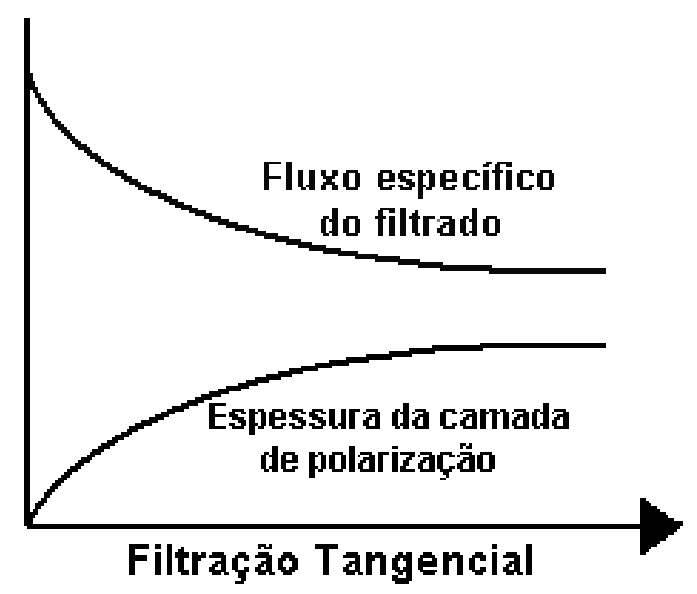

(a)

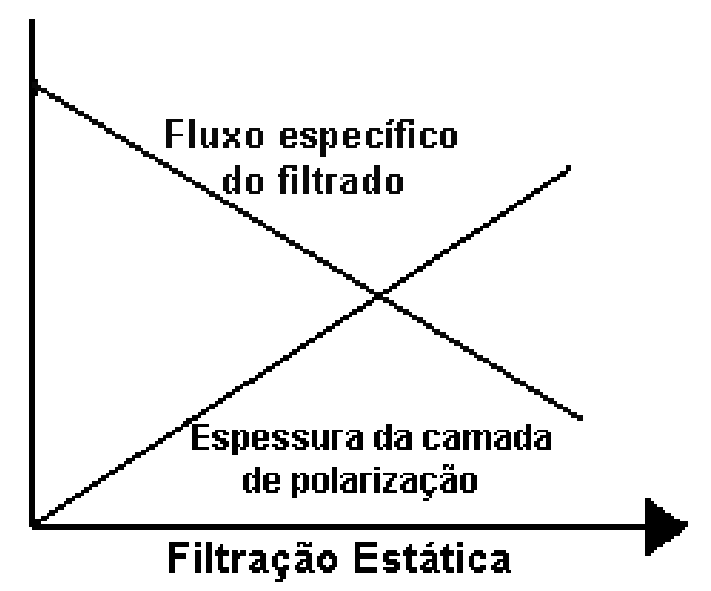

(b)

Figura 3 - Comportamento da espessura da camada de polarização e fluxo específico do filtrado ao longo da operação, na filtração estática (a) e tangencial (b). Adaptado de HUGO SANTOS, 1992.

Na filtração tangencial, a maioria das partículas depositadas, é arrastada para fora da unidade pela ação da velocidade tangencial. Mas muitas técnicas têm sido adotadas para se evitar que as partículas se depositem nas membranas; como o uso de abrasivos, auxiliares de filtração e coagulantes. Utilizam-se também, retrolavagens periódicas, freqüências de ultra-som, fluxos pulsados, podendo remover partículas já localizadas nas membranas ou na sua superfície (VIDAL, 2001).

Para HUNT et al. (1987), RIPPERGER (1988) e PILLAY \& BUCKLEY (1992), na MFT, o fluxo tangencial gera forças de cisalhamento e ou turbulências ao longo do meio filtrante limitando a espessura da camada de substâncias retidas na superfície da membrana. Segundo estes autores, no fluxo de filtrado em regime permanente, a espessura desta camada permanece constante.

A vazão de permeado na filtração tangencial é influenciada por um grande número de parâmetros, como por exemplo, velocidade tangencial, pressão transmembrana, resistência hidráulica da membrana, resistência da camada gel-polarizada, distribuição das partículas em suspensão, forma das 
partículas, comportamento químico da aglutinação das partículas na superfície, dentre outros (FERREIRA, 2003).

Esse comportamento de acúmulo de substâncias retidas na superfície da membrana também é definido como processo de polarização (Schuz \& RIPPERGER (1989) e POULIOT et al. (1995)).

Um dos parâmetros mais importantes na MFT é a pressão transmembrana, que segundo RIPPERGER (1995) e MURADIUM FILHO (1989) é definida pela diferença entre as médias das pressões na entrada e na saída da membrana e a pressão do filtrado.

Assim, como existem parâmetros relacionados ao processo de microfiltração tangencial, existem aqueles relacionados diretamente ao fluxo do filtrado, também chamado de permeado e que segundo MICHAELS (1989) são:

a-) Permeabilidade da membrana: quanto mais permeável, maior é o fluxo;

b-) Comportamento mecânico dos sólidos no que diz respeito à compressibilidade, densidade e distribuição dos tamanhos: sólidos de tamanho uniforme permitem fluxos maiores do que aqueles de tamanho não uniforme;

c-) Comportamento adsortivo dos sólidos ou dos componentes dissolvidos no líquido: quanto menor a adsorção maior a permeabilidade;

d-) Viscosidade da fase líquida: quanto maior a viscosidade menor é o fluxo;

e-) Queda de pressão: freqüentemente a elevação do diferencial de pressão eleva o fluxo;

f-) Velocidade de cisalhamento aplicada ao produto no canal de fluxo do microfiltro: quanto maior a velocidade, mais fina é a camada de sólidos retidos na superfície da membrana.

Para se ter uma idéia da relevância da microfiltração tangencial, o Instituto IREPOLIA (Institut de Recherche sur l'Élimination dês Pollutions d'Origine Industrielle et Agro-alimentaire) implantou uma unidade autônoma de 
potabilização de água por microfiltração tangencial utilizando membranas cerâmicas (LEGERON, 1993).

LANGLAIS et al. (1993) testaram a eficiência da microfiltração tangencial aplicada a um efluente. As características do efluente na saída do biofiltro apresentaram: DQO (demanda química de oxigênio) com valores entre $100 \mathrm{e}$ $400 \mathrm{mg} / \mathrm{L}$ e SST (sólidos sUSPensos totais) entre 15 e $90 \mathrm{mg} / \mathrm{L}$. A microfiltração $(0,2 \mu \mathrm{m})$ eliminou todos os microrganismos indicadores de contaminação fecal (streptococos fecais, coliformes fecais e totais). A redução da DQO chegou até $60 \%$ e a eliminação da turbidez, a $99 \%$. Nas condições adotadas, o ciclo mínimo de filtração durou 72 horas para uma vazão mínima permeado de $80 \mathrm{~L} /\left(\mathrm{h} \cdot \mathrm{m}^{2}\right)$.

\subsection{Membranas}

Desde o início do século XVIII, as propriedades das membranas são conhecidas, mas suas aplicações em laboratório e também na indústria começaram a se desenvolver a partir da metade do século XIX.

A membrana é uma barreira fina através da qual solventes e solutos são transportados seletivamente. A membrana pode ser constituída por um polímero orgânico ou inorgânico, camadas químicas ou mesmo líquidos ou gases. O trabalho prático dessa barreira fundamenta-se nas propriedades das membranas semi-permeáveis que podem ser definidas como o conjunto de métodos e propriedades concernente ao transporte de matéria através de materiais com permeabilidades seletivas.

\subsubsection{MATERIAIS DAS MEMBRANAS}

As membranas apresentam grande diversidade de texturas físicas (densas ou porosas) e de origem (natural ou artificial). Elas podem ser inorgânicas (cerâmicas), orgânicas (polímeros sintéticos), mistas, neutras ou trocadoras de íons, homogêneas ou de estrutura assimétrica.

Uma membrana porosa deve possuir boa resistência mecânica, porém espessura fina que permita vazão de permeação elevada. Essas duas 
exigências contraditórias são resolvidas através da construção de membranas com estruturas assimétricas. A essa categoria pertencem as membranas 'composites' que são construídas a partir da superposição de várias camadas diferenciadas por seu estado físico. Assimétricas ou 'composites', as membranas são formadas de um suporte poroso que assegura as funções mecânicas e de uma película ativa de pouca espessura que assegura as funções separativas (RESEAU NOVELECT - INNOVATION ÉNERGÉTIQUE ÉLECTRICITÉ, 1993).

As membranas homogêneas são sólidos microporosos ou densos constituídos de diferentes camadas de porosidade constante, ou de porosidade decrescente ou, ainda, de estrutura assimétrica. A região superficial (película) apresenta uma porosidade mais fraca. Essas membranas são constituídas por polímeros (acetato de celulose) ou por substâncias inorgânicas (vidro ou metais cozidos).

As membranas minerais são de estrutura assimétrica. O suporte e a película ativa podem ser compostos de diferentes materiais (membrana 'composite') ou de materiais de mesma natureza. Suas características de resistência mecânica, térmica e química são bastante favoráveis. Sua duração chega a vários anos e podem ser facilmente limpas por contra-pressão. Elas suportam bem a esterilização, e são resistentes ao ataque bacteriano. Apresentam configuração tubular ou multicanais.

\subsubsection{ClassificaÇÃo dAS MEMBRAnAS}

As membranas podem ser classificadas segundo vários aspectos:

a-) natureza natural ou sintética;

b-) estrutura porosa ou não porosa;

c-) ação de mecanismo: adsortiva ou difusiva, troca iônica, osmótica ou membranas não seletivas.

De acordo com a ESMST (European Society of Membrane Science and Technology), as membranas classificam-se em: 
$>\quad$ Membranas isótropas: aquelas que possuem diâmetro de poro regular em toda sua espessura. Devido à consideráveis perdas de carga e à sensibilidade aos ataques de microrganismos, são pouco utilizadas em aplicações industriais. Essa perda de carga ligada ao fraco fluxo de permeado está associada à grande espessura e duração de vida relativamente curta, devido a sua sensibilidade à hidrólise e aos ataques bacterianos.

$>$ Membranas anisótropas: aquelas que possuem diâmetro de poro que aumenta a medida que se aprofunda a camada filtrante, apresentando assim, boas propriedades mecânicas e proporcionando um melhor fluxo de permeado (camada filtrante muito fina sobre uma estrutura mais espessa e mais porosa). São compostas de material cerâmico hidrófobo, resistem bem aos ataques químicos e bacterianos, não suportando, porém, altas temperaturas e valores extremos de $\mathrm{pH}$. São fabricadas a base de polímeros orgânicos como as poliamidas, polisulfonas, policarbonatos ou polifluoreto de vinilideno.

\section{$>\quad$ Membranas 'composite' (orgânicas ou minerais): aquelas} formadas de uma camada filtrante sobre um suporte, sendo freqüentemente assimétricas. São mais recentes e apresentam melhor desempenho. As membranas minerais são confeccionadas em óxido de zircônio sobre suporte de fibra de carbono ou de alumina $\left(\mathrm{Al}_{2} \mathrm{O}_{3}\right)$. Elas apresentam boa resistência aos agentes químicos $(1<\mathrm{pH}<14)$, aos solventes, aos oxidantes, a fortes pressões e a altas temperaturas (MOULIN, 1987).

\subsubsection{CARACTERÍSticas dA FILTRAÇÃo COM MEMBRANAS}

A utilização de membrana tem por objetivo principal realizar a separação de substâncias de diferentes propriedades (tamanho, forma, difusividade, etc). A separação pode ser de misturas de gases e vapores, líquidos miscíveis, sólido/líquido, líquido/líquido e sólidos dissolvidos. Na Figura 4, pode-se observar os diferentes tipos de filtração, segundo o tamanho médio das partículas e o tamanho dos poros da membrana.

O principal aspecto que diferencia a separação por membrana de outras técnicas de separação é o uso de outra fase, a membrana. Esta fase, líquida, 
sólida ou gasosa, introduz uma interface entre as duas fases envolvidas na separação e pode proporcionar vantagens na eficiência e seletividade.

Certos elementos da solução filtrante podem ser pressionados através da membrana pela aplicação de uma força direcionada (pressão, concentração, potencial elétrico, etc). A membrana controla a taxa relativa do transporte de várias espécies, e como toda separação, proporciona um produto com baixas concentrações de um determinado componente e um outro produto com altas concentrações do mesmo.

O desempenho da membrana é definido em termos de dois fatores simples, fluxo e retenção ou seletividade. Fluxo ou taxa de permeado é o fluxo volumétrico de fluido que passa através da membrana por unidade de área por tempo. Seletividade é uma medida da taxa relativa de permeado de vários componentes através da membrana (QUEIROZ, 2004).

Dentre as membranas inorgânicas, destacam-se as cerâmicas por serem ótimos materiais para a produção dos tubos de filtração, pois permite alta velocidade de alimentação da filtração tangencial, resultando em um regime turbulento que previne a formação de incrustações e garante um fluxo altamente permeável.

As membranas inorgânicas e de cerâmicas, geralmente, são encontradas na forma tubular, sendo de canal simples ou de multicanal. Cuidados especiais devem ser tomados com seus O-rings, gaxetas e tampões que são utilizados para manter seus elementos em suas posições. Em todos os módulos inorgânicos, a alimentação flui dentro dos canais, enquanto o permeado flui através do suporte.

SONDHI et al. (2003) relatam que membranas cerâmicas são ideais para limpeza com agentes químicos a altas temperaturas, de vez em quando usando soda cáustica, cloro, peróxido de hidrogênio, ozônio e ácidos inorgânicos fortes e/ou usando esterilização a vapor. Essas membranas também podem ser forçadas reversamente, que é basicamente uma técnica que inverte o fluxo do permeado para reduzir o "fouling" (obstrução irreversível dos poros) e a camada de polarização, e conseqüentemente aumentar a 
eficiência da filtração. Esta técnica é um método "in situ" para limpar a membrana por reverter periodicamente o fluxo do permeado através da pressão aplicada ao lado do permeado.

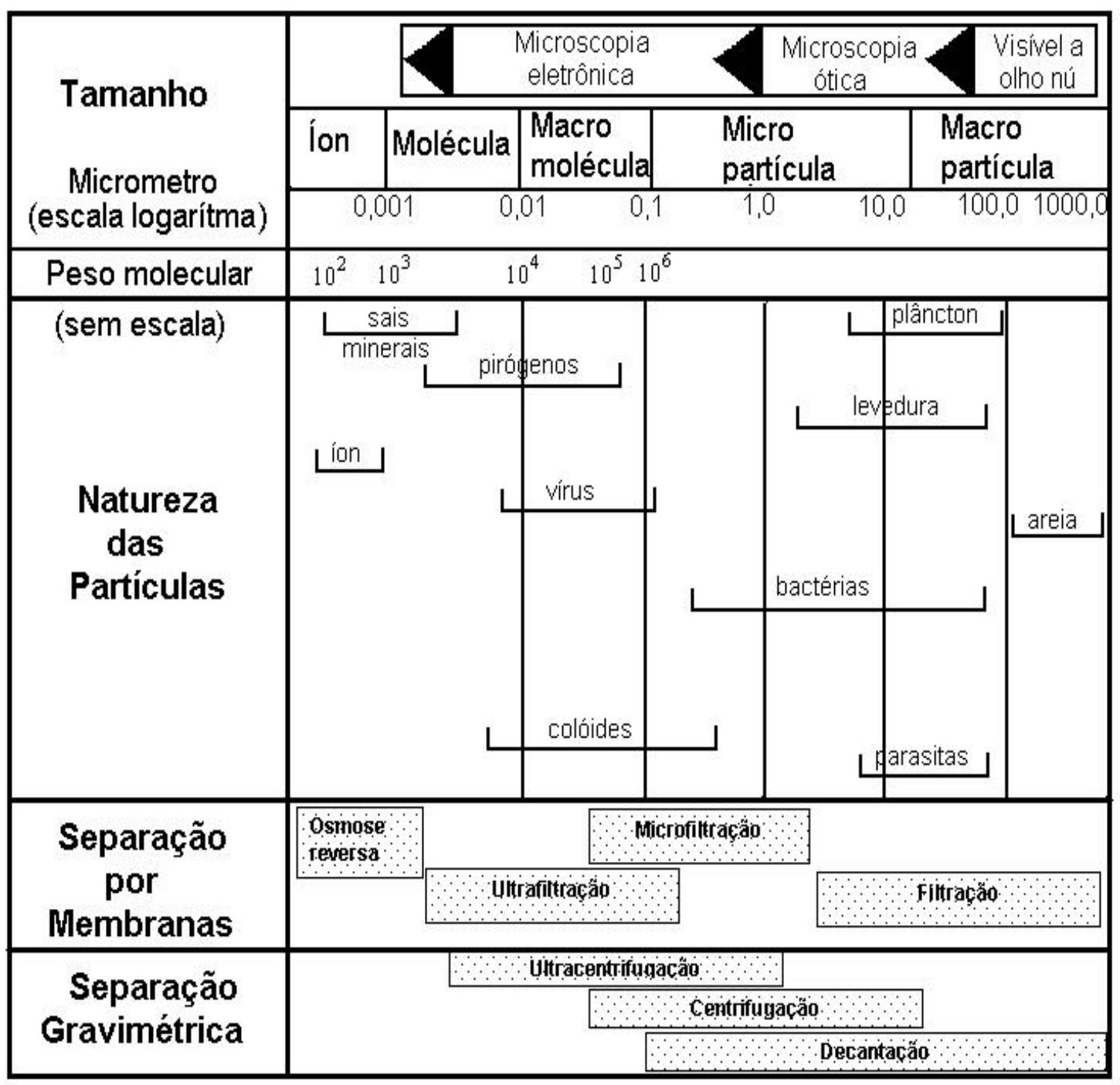

Figura 4 - Espectro de filtração segundo o tamanho das partículas Adaptado de LACOSTE, 1992.

\subsection{POROSIDADE}

Porosidade é a relação entre a parte sólida e os poros da membrana, isto é, pode ser considerada como a quantidade de vazios em uma estrutura. A porosidade pode ser considerada apenas da parte superficial da membrana, ou seja, da camada filtrante, e neste caso, será expressa em poros $/ \mathrm{m}^{2}$. Quanto maior a porosidade da subcamada, menor a resistência ao fluxo do solvente através da membrana. A porosidade da membrana relaciona-se diretamente com o processo utilizado em sua preparação ou em seu pós- 
tratamento (PETRUS, 1997 apud LAPOLLI (1998, p.20) e VIDAL (2001, p.16))

Podemos citar alguns métodos utilizados para se medir o diâmetro médio dos poros de uma membrana, como por exemplo:

\section{a) Medida direta com auxílio do microscópio eletrônico de varredura;}

Neste método, a imagem é registrada com o auxílio de um microscópio eletrônico e com o auxílio computacional de tratamento de imagens, podendose medir os diâmetros dos poros na superfície. Porém, esse método apresenta limitações quando os poros são muito pequenos e com variedade de tamanhos e, também quando ocorrem fraturas na superfície que podem ser confundidas com poros (LAPOLLI, 1998).

\section{b) Porosidade por intrusão de mercúrio;}

O método de porosimetria por intrusão de mercúrio foi proposto em 1921 por Washburn, que sugeriu ser possível se obter a distribuição de diâmetros de poros a partir dos dados pressão-volume durante a penetração de um material poroso pelo mercúrio, foi efetivamente aplicada por Henderson et al. em 1940 e vem se desenvolvendo desde então.

Porosimetria de Mercúrio caracteriza a porosidade de um material através da aplicação de várias pressões em uma amostra imersa em mercúrio. A pressão necessária para introduzir mercúrio dentro da amostra é inversamente proporcional ao tamanho dos poros (LAPOLLI, 1998). Isto é chamado mais freqüentemente de intrusão de mercúrio. A técnica de análise de porosimetria de mercúrio é baseada na intrusão de mercúrio em uma estrutura porosa sob pressões rigorosamente controladas. Dos dados de pressão versus intrusão, o instrumento gera distribuição de volume e tamanho dos poros usando a equação de Washburn.

Como o mercúrio não molha a maioria das substâncias e não penetra os poros espontaneamente por ação capilar, ele deve ser forçado para dentro dos poros através da aplicação de pressão externa. A pressão necessária é inversamente proporcional ao tamanho dos poros, sendo exigidas apenas 
pequenas pressões para introduzir mercúrio nos poros grandes (macroporos) enquanto pressões muito maiores são necessárias para forçar mercúrio para dentro dos poros. Assim, quanto mais precisa as determinações de pressão, mais preciso os dados de tamanho de poros resultantes.

c) Porosimetria de deslocamento de líquido;

O método utiliza dois líquidos imiscíveis com tensões interfaciais conhecidas, sendo que a membrana é preenchida com um dos líquidos e, o outro, é forçado gradualmente e sob pressão através da membrana. Mede-se o fluxo de permeado e a pressão de equilíbrio. Através da combinação da equação de Cantor com a equação de Hagen-Poiseuille, pode-se determinar o perfil de distribuição do diâmetro dos poros de uma membrana (LAPOLLI, 1998). De acordo com BOTTINO et al (1991) este método apresenta a vantagem de trabalhar com baixas pressões.

\section{d) Uso de soluções de polímeros polidispersos.}

Os poros de uma membrana estão distribuídos de forma binodal em função de seus diâmetros na superfície da membrana. Em vista disso, a retenção de macromoléculas apresenta dependência na forma sigmoidal frente a sua massa molecular. Este método é mais utilizado para determinar a zona e o ponto de corte de uma membrana, sendo que a zona de corte apresenta a região em que macromoléculas de diferentes massas moleculares são parcialmente retidas e o ponto de corte é expresso como a massa molecular da menor molécula retida (LAPOLLI, 1998).

\subsection{Seletividade e PeRmeabilidade}

A seletividade de uma membrana está relacionada com a distribuição de diâmetros dos poros em sua estrutura. Não é comum a existência de membranas com diâmetros de poros únicos, e sim, com uma certa distribuição em torno de um diâmetro médio (VIDAL, 2001).

O material que atravessa a membrana pode ser medido pela sua permeabilidade. O mecanismo de transporte é o fluxo capilar convectivo, em que cada poro é assimilado a um capilar e a soma de 
todos os escoamentos fornece o fluxo total (DUCLERT, 1989 apud LAPOLLI (1998, p. 23) e VIDAL (2001, p. 17)).

A permeabilidade à água permite avaliar a porosidade superficial e da subestrutura da membrana, fornecendo informações sobre as propriedades hidrofílicas/hidrofóbicas, portanto, sendo fundamental para a sua caracterização (LAPOLLI, 1998 apud VIDAL (2001, p. 17)).

\subsubsection{MODELO DE RESISTÊNCIA DURANTE A FILTRAÇÃO TANGENCIAL}

É possível estudar a permeabilidade nas estruturas cerâmicas sujeitas à impregnação físico-química (depósitos) de acordo com a lei de Darcy. Essa lei é relatada para a resistência hidráulica, sendo a soma da resistência inicial da membrana $\left(R_{m}\right)$, com fluxo de água potável, e da resistência da camada gel polarizada $\left(R_{g}\right)$.

O fluxo do permeado pode ser escrito como mostra a Equação 1 (HAMACHI; MIETTON-PEUCHOT, 1999).

$$
J=\frac{\Delta P}{\mu\left(R_{g}+R_{m}\right)}
$$

Onde:

J: fluxo do permeado (expresso em $\mathrm{m}^{3} / \mathrm{m}^{2} . \mathrm{s}$ );

$\Delta \mathrm{P}:$ pressão transmembrana $(\mathrm{Pa})$

$\mu$ : viscosidade dinâmica da água considerando o permeado (Pa.s);

$\mathrm{R}_{\mathrm{g}}$ : resistência da camada gel polarizada $\left(\mathrm{m}^{-1}\right)$;

$R_{m}$ : resistência da membrana $\left(\mathrm{m}^{-1}\right)$.

VIDAL (2001) e LAPOLLI (1998) em seus trabalhos de pesquisa utilizaram a lei de Hagen-Poiseuille para calcular a resistência total da membrana e resistência devido à polarização ao longo do processo de microfiltração tangencial. Essa lei permite expressar o transporte de solvente por uma membrana, na qual o fluxo do solvente é expresso da seguinte maneira: 
$J=\frac{N \cdot \pi \cdot d p^{4} \cdot \Delta P}{128 \cdot \mu \cdot \ell}$

Em que:

J: fluxo do solvente (normalmente expresso em m/s);

$\mathrm{N}$ : número de poros por unidade de superfície $\left(\mathrm{m}^{-2}\right)$;

$\mathrm{d}_{\mathrm{p}}$ : diâmetro de poros $(\mathrm{m})$;

$\Delta \mathrm{P}$ : pressão transmembrana $(\mathrm{Pa})$;

$\mu$ : viscosidade dinâmica (Pa.s);

$\ell$ : comprimento do poro $(\mathrm{m})$.

Sendo:

$\mathrm{N}=(4 . \varepsilon) /\left(\pi \cdot \tau \cdot \mathrm{d}_{\mathrm{P}}^{2}\right)$

Em que:

$\varepsilon$ : porosidade (s.d);

$\tau:$ fator de tortuosidade (s.d);

$\mathrm{d}_{\mathrm{P}}$ : diâmetro dos capilares $(\mathrm{m})$.

Substituindo-se a equação (3) na equação (2) tem-se:

$J=\frac{\left(\varepsilon \cdot d p^{2}\right)}{(32,1 . \tau)} x \frac{\Delta P}{\mu}=\frac{\Delta P}{\mu} x R_{T}$

Em que:

$\mathrm{R}_{\mathrm{T}}$ : resistência total da membrana $\left(\mathrm{m}^{-1}\right)$.

Para soluções que apresentem diferentes tipos de macromoléculas de massas moleculares variadas e partículas em suspensão, deve-se levar em consideração outras resistências ao fluxo de permeado. Assim, a Equação 4 é expressa por: 


$$
J=\frac{\Delta P-\Delta \pi}{\mu \cdot\left(R_{M}+R_{p}+R_{g}+R_{c}\right)}
$$

\section{Em que:}

J: fluxo do permeado $(\mathrm{m} / \mathrm{s})$;

$\Delta \mathrm{P}$ : pressão mecânica aplicada $(\mathrm{Pa})$;

$\Delta \pi$ : pressão osmótica $(\mathrm{Pa})$;

$\mu$ : viscosidade da solução (Pa.s);

$\mathrm{R}_{\mathrm{M}}$ : resistência da membrana $\left(\mathrm{m}^{-1}\right)$;

$R_{p}$ : resistência da zona de polarização $\left(\mathrm{m}^{-1}\right)$;

$\mathrm{R}_{\mathrm{g}}$ : resistência da camada gel polarizada $\left(\mathrm{m}^{-1}\right)$;

$\mathrm{R}_{\mathrm{c}}$ : resistência devido à formação da camada de polarização $\left(\mathrm{m}^{-1}\right)$.

Fonte: LAPOLLI, 1998.

A equação (5) também pode ser expressa da seguinte maneira:

$$
J=\frac{\Delta P}{\mu \cdot\left(R_{M}+R_{C}\right)}
$$

Onde:

$R_{m}+R_{p}+R_{g}+R_{c}=R_{T}$, onde: $R_{T}=R_{m}+R_{C} \quad$ e $\quad R_{p}+R_{g}+R_{c}=R_{C}$

$\mathrm{R}_{\mathrm{C}}$ : resistência total à formação da camada de polarização $\left(\mathrm{m}^{-1}\right)$;

$\mathrm{R}_{\mathrm{T}}$ : resistência total da membrana $\left(\mathrm{m}^{-1}\right)$.

Como o fluxo do permeado (J) e a superfície da camada de polarização $\left(\mathrm{ep}_{\mathrm{g}}\right)$ tendem para o estado estacionário, o produto $\left(\mathrm{J} \times \mathrm{ep}_{\mathrm{g}}\right)$ também tende para um valor limite. Para uma pressão e concentração constante, todas as curvas de "J" convergem para o mesmo ponto, qualquer que seja a velocidade da corrente do fluido (HAMACHI; MIETTON-PEUCHOT, 1999).

Além disso, com o tempo, a resistência da camada gel polarizada acaba tornando-se preponderante em proporção à resistência da membrana $\left(R_{m}\right)$, 
onde a última pode ser negligenciada em comparação à camada gel polarizada, como mostra a equação simplificada (Equação 7).

$$
J_{x e p_{g}}=\frac{B}{\mu} \Delta P
$$

Considerando que a viscosidade da suspensão e a pressão transmembrana são constantes, a permeabilidade de depósito (B) deve ser também constante, qualquer que seja velocidade tangencial para uma concentração e pressão.

A permeabilidade associada ao depósito físico-químico aumenta sistematicamente conforme o aumento da pressão transmembrana, isso pode ser atribuído à compressibilidade do depósito ou camada de polarização com finas partículas devido a maiores volumes de filtrado nas altas pressões. Isso explica a dependência do fluxo do permeado (ou transmembrana) como função da camada de depósito.

Além disso, para uma mesma superfície permeável polarizada, o fluxo de permeado é sempre maior tendo-se concentrações maiores. Uma razão para isso pode ser porque sUSPensões de concentrações diluídas contêm menos matéria sujeita a interação físico-química com a superfície permeável.

O conhecimento de taxas de permeado e camada de depósito durante a filtração permite calcular a resistência em diferentes condições de polarização. Seguindo-se a lei de Darcy, a resistência total $\left(R_{T}\right)$ dos poros médios é a soma da resistência da membrana $\left(R_{m}\right)$ e da resistência da camada gel polarizada $\left(\mathrm{R}_{\mathrm{g}}\right)$.

$$
R_{T}=R_{m}+R_{g}=\frac{\Delta P}{\mu J}
$$

Onde:

$\mathrm{R}_{\mathrm{T}}$ : resistência total da membrana $\left(\mathrm{m}^{-1}\right)$;

$\mathrm{R}_{\mathrm{m}}$ : resistência da membrana $\left(\mathrm{m}^{-1}\right)$;

$\mathrm{R}_{\mathrm{g}}$ : resistência da camada gel $\left(\mathrm{m}^{-1}\right)$; 
$\Delta \mathrm{P}$ : pressão mecânica aplicada $(\mathrm{Pa})$;

$\mu$ : viscosidade dinâmica da água (Pa.s);

J: fluxo do permeado $\left(\mathrm{m}^{3} / \mathrm{m}^{2} . \mathrm{s}\right)$.

Fonte: HAMACHI; MIETTON-PEUCHOT, 1999.

\subsection{Camada de polarizaÇÃo}

É comum observar que no início de qualquer operação de filtração, o fluxo do permeado ou filtrado diminui progressivamente até um valor estabelecido, devido a uma formação da camada crítica nas proximidades da parede da membrana. Quando a filtração é do tipo tangencial, ocorre uma contínua redução do fluxo de permeado (Figura 5), na qual vários mecanismos estão envolvidos.

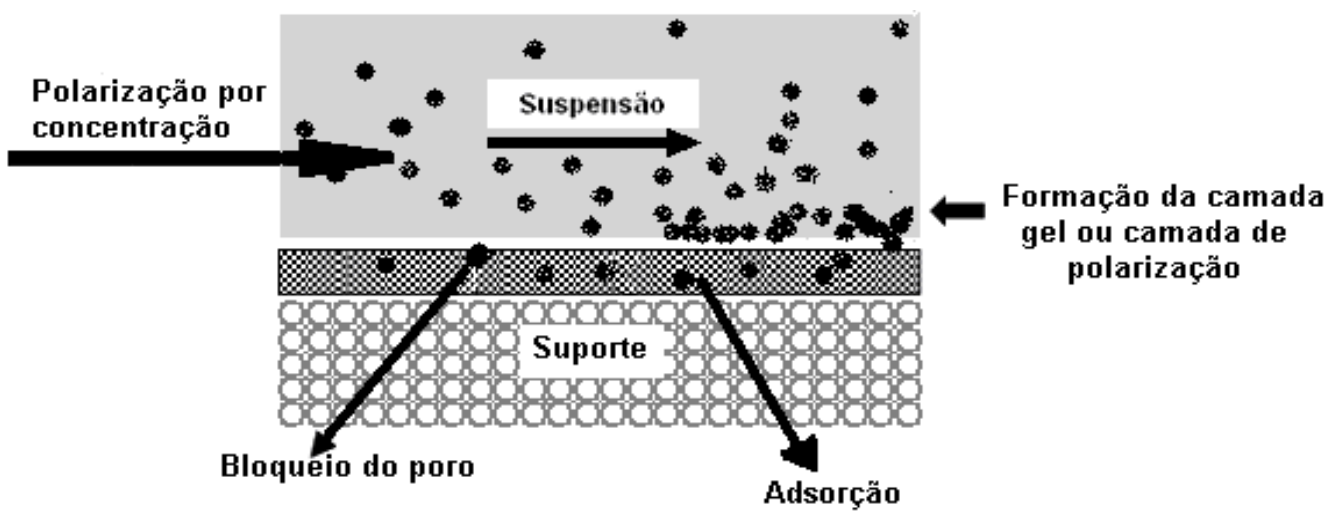

Figura 5 - Mecanismos envolvidos na polarização de membranas

Fonte: WISNIEWSKI, 1996.

O entupimento gradual dos poros de um material microporoso, conhecido por polarização é um dos principais problemas das unidades de microfiltração. Segundo, LAPOLLI (1998) apud VIDAL (2001), "o termo polarização indica particularmente, a obstrução progressiva dos poros da membrana como resultado da penetração de solutos presentes em soluções macromoleculares ou em suspensão coloidal".

VISVANATHAN et al. apud WISNIEWSKI (1996) estabeleceram algumas hipóteses para justificar o fenômeno da polarização, e dentre elas, pode-se 
citar:

- A acumulação de partículas sobre a membrana formando uma camada de polarização por concentração ou camada gel, cujas propriedades podem evoluir ao longo da operação;

- Ao bloqueamento dos poros ou adsorção de partículas na superfície externa ou no interior dos poros da membrana, dificultando a passagem do permeado.

\subsection{ATIVIDADE QUÍMICA NA MEMBRANA}

Para fins particulares de ação bactericida, é interessante que a membrana ou superfície seletiva seja quimicamente ativa pela ação da prata.

A prata é um metal branco, maleável e dúctil. Apresenta um elevado peso específico $\left(10,5 \mathrm{~g} \mathrm{ml}^{-1}\right)$ e funde a $960,5^{\circ} \mathrm{C}$. É insolúvel em ácido clorídrico, sulfúrico diluído (M) e nítrico diluído (2M). Dissolve-se em ácidos mais concentrados, tais como: ácido nítrico (8M) (9) ou em ácido sulfúrico concentrado a quente (10):

$$
\begin{aligned}
& 6 \mathrm{Ag}+8 \mathrm{HNO}_{3} \rightarrow 6 \mathrm{Ag}^{+}+2 \mathrm{NO} \uparrow+6 \mathrm{NO}_{3}^{-}+4 \mathrm{H}_{2} \mathrm{O} \\
& 2 \mathrm{Ag}+2 \mathrm{H}_{2} \mathrm{SO}_{4} \rightarrow 2 \mathrm{Ag}^{+}+\mathrm{SO}_{4}^{2-}+\mathrm{SO}_{2} \uparrow+2 \mathrm{H}_{2} \mathrm{O}
\end{aligned}
$$

A prata em solução forma íons monovalentes incolores. Os compostos de prata (II) não são estáveis, mas desempenham uma função importante nos processos de óxido-redução catalisados pela prata. O nitrato de prata é facilmente solúvel em água, e o acetato, nitrito e sulfato de prata são menos solúveis, enquanto todos os outros compostos de prata são insolúveis. Os complexos de prata, não obstante, são solúveis. Os halogenetos de prata são sensíveis à luz, sendo esta característica amplamente utilizada em fotografia (VOGEL, 1905).

A prata tem sido utilizada durante séculos na atividade de purificação da água. Na antiga civilização grega, a realeza utilizava cálices de prata para beber e sua água era estocada e organizada em barris de prata para purificar a água potável. Conforme os exploradores atravessavam o Oeste do Continente 
Americano, eles guardavam água potável desinfectada, colocando-se moedas de prata nos seus barris de água e leite (RESEARCH ON THE BENEFITS OF SILVER).

Em 1919, Alfred Searle escreveu em seu livro "O Uso dos Colóides na saúde e na doença" que "A aplicação de prata coloidal em seres humanos, em grande número de casos, tem apresentado resultados positivos surpreendentes. Para uso interno, oral ou hipodérmico, tem a vantagem de ser rapidamente fatal aos parasitas sem qualquer ação tóxica na pessoa...".

Em 1929, na Alemanha, o Dr. G. Krausel conseguiu tornar prático o uso de íons metálicos, tais como prata e cobre, para ação bactericida. Desde então, muitos avanços tecnológicos ocorreram nessa área. No ano de 1960, a Nasa desenvolveu um ionizador eletrolítico de prata para purificar a água potável consumida pelos astronautas durante a Missão Apolo. Hoje, a prata é utilizada em tratamentos médicos de pacientes com queimaduras, a fim de prevenir infecções, em recém-nascidos para evitar a cegueira, na fabricação de cosméticos isentos de bactérias, em filtros de água potável e em obturação de dentes, auxiliando na prevenção de um reaparecimento de cáries.

Dez anos mais tarde, pesquisas biomédicas feitas na Washington University em St. Louis, Missouri, Estados Unidos, mostraram que nenhum organismo patogênico, seja micróbio, vírus ou fungo, pode viver mais que alguns minutos na presença, mesmo de traços, de prata metálica.

A prata também é utilizada como algicida e como bactericida em vários sistemas de purificação de água de hospitais e mais recentemente, está sendo utilizada na desinfecção da água de piscina com propriedades bactericidas, onde pequenas concentrações de prata ou mesmo de sais de prata matam quaisquer bactérias, uma vez que afetam quimicamente as membranas celulares bacterianas, causando a lise das mesmas (RESEARCH ON THE BENEFITS OF SILVER).

Atualmente, células de Escherichia coli foram tratadas em placas de Petri com agar sólido, utilizando-se o meio de cultura Luria-Bertani (LB), e em sistemas líquidos supridos com diferentes concentrações de nano-partículas de 
prata. Os resultados foram bem promissores, uma vez que se notou a danificação das células de E.coli quando em sistemas contendo nanopartículas de prata, mostrando a formação de "buracos" na parede da célula bacteriana, enquanto as nano-partículas de prata eram encontradas acumulando-se na membrana bacteriana. A membrana com uma morfologia semelhante mostra um aumento significativo na permeabilidade, resultando na morte da célula (SONDI, SALOPEK-SONDI, 2004).

Atualmente, agentes anti-sépticos são levados em consideração para o tratamento de gordura localizada e feridas infeccionadas porque eles têm uma menor propensão para induzir resistência bacteriana do que os antibióticos (PERCIVAL, BOWLER, RUSSEL, 2005).

Atualmente, um grande número de produtos medicinais contém prata, principalmente devido a suas atividades antimicrobianas e baixa toxicidade às células humanas (PERCIVAL, BOWLER, RUSSEL, 2005).

\subsection{MOdO dE AÇÃO dA PRATA $\left(\mathrm{AG}^{+}\right)$}

Sabe-se que em bactérias, íons de prata reagem com resíduos de aminoácidos nucleofílicos nas proteínas, e atacam grupos: sulfidrila, amino, imidazol, fosfato e carboxílico de membranas ou de enzimas proteolíticas que acarretam na desnaturação protéica (RUSSELL e HUGO, 1994; KAUR, SAXENA e VADEHRA, 1985; HOSTYNEK et al., 1993).

A prata também é conhecida por inibir algumas enzimas oxidativas, tal como a desidrogenase da fermentação alcoólica, por inibir a síntese de succinato pelas vesículas da membrana e a cadeia respiratória de E. coli, assim como causa o efluxo metabólico e interfere na replicação do DNA (PERCIVAL, BOWLER, RUSSEL, 2005). Um dos principais alvos da prata $\left(\mathrm{Ag}^{+}\right)$, especificadamente a baixas concentrações, apresenta-se na $\mathrm{Na}^{+}$. translocating NADH: sistema succinato-ubiquinona redutase (SEMEYKINA, SKULACHEV, 1990; HAYASHI et al., 1992). A prata também têm sido vista associada à parede celular, citoplasma e a membrana celular.

Em um complexo sistema biológico, como por exemplo, fluido de uma 
ferida, o nível máximo de prata livre é aproximadamente $1 \mu \mathrm{g} / \mathrm{mL}$ (acima deste nível, complexos de prata com ânions, como por exemplo cloreto, formam sal inativo e pouco solúvel). Cloreto (iônico) presente na exsudação de feridas crônicas e críticas afetam a disponibilidade de prata iônica. A solubilidade de cloreto de prata é 14M (BELLY e KYDD, 1982) e AgSD é 3M (NESBITT JR. e SANDMANN, 1977). Na presença de grande quantidade de cloreto de sódio, a concentração de prata $\left(\mathrm{Ag}^{+}\right)$livre é reduzida para aproximadamente $2 \mathrm{nM}$, independente da concentração de nitrato de prata adicionado (KAUR, SAXENA, VADEHRA, 1985). Experimentos de Gupta et al. (1998) tem mostrado que cloretos apresentam 3 níveis de efeito na prata disponível. Em ambientes externos, $\mathrm{Ag}^{+}$liga-se fortemente à superfície da célula bacteriana com efeitos tóxicos, freqüentemente inibindo o transporte da cadeia respiratória (BRAGG e RAINNIE, 1974). A prata é ativa contra bactérias, fungos e patógenos virais a concentrações de $10^{-9}$ até $10^{-6} \mathrm{M}$ (RUSSELL e HUGO, 1994).

Os íons de prata, em baixas dosagens, atuam na atividade celular pela ação oligo-dinâmica:

$$
\mathrm{R}-\mathrm{S}-\mathrm{H}+\mathrm{Ag}^{+} \rightarrow \mathrm{R}-\mathrm{S}-\mathrm{Ag}+\mathrm{H}^{+}
$$

Sendo que o radical S-Ag influi na multiplicação bacteriana de forma constante e permanente. A prata no seu estado atômico tem a capacidade de absorver oxigênio e agir como um catalisador, provocando oxidação. 0 oxigênio atômico (nascente) absorvido na superfície dos íons de prata em solução irá reagir com os grupos sulfidrilas $(-\mathrm{S}-\mathrm{H})$ adjacentes à superfície da bactéria ou do vírus para remover os átomos de hidrogênio (como água), fazendo os átomos de enxofre formarem uma barreira $R-S-S-R$; bloqueando a respiração e causando a morte da bactéria. Micro-cristais de prata tem a tendência de rapidamente demarcar o oxigênio nascente e estas espécies facilmente oxidam bactérias ou vírus, resultando numa completa desintegração (HEINIG, 1986).

Dependendo da quantidade de íons de prata, da condição do meio onde está aplicado, e dos tipos de colônias de microrganismos, pode-se fazer o produto atuar não só na eliminação microbiana, mas na manutenção de uma atividade de "hibernação" destas colônias, vedando suas atividades 
proliferativas (SALVO, 2005).

Há dois tipos de ações do ponto de vista microbiológico:

\# Devido à liberação do íon de prata na água ou no ar (ambiente úmido), ocorre a ação catalítica do íon de prata destruindo a membrana plasmática das bactérias, pela diferença de potencial (eletropotência) entre a parte interna e externa das células (SALVO, 2005).

\# Outra ação deve-se ao íon de prata no ambiente úmido (água ou ar) penetrar na membrana plasmática da célula bacteriana, destruindo 0 citoplasma da célula (SALVO, 2005).

\subsection{MICRORGANISMOS E RESISTÊNCIA BACTERIANA}

Os procariotos (organismos unicelulares simples com um único cromossomo, sem membrana nuclear e sem organelas ligadas a membranas) são células simples, microscópicas e de origem mais antiga. Essas células consistem de diferentes famílias de microrganismos unicelulares geralmente chamados de bactérias. As células procarióticas foram as primeiras a surgir na evolução; fósseis remanescentes de tais células, datados com mais de 3 bilhões de anos de idade ( $3 \times 10^{9}$ anos), foram encontrados em rochas de xisto na África, bem como na Austrália.

Há cerca de 20 famílias diferentes de procariotos, que são classificados de acordo com sua forma, sua capacidade de locomoção, suas características de coloração, suas preferências nutricionais ou produtos que sintetizem (LEHNINGER, 1993).

Devido a sua estrutura simples, a velocidade, facilidade com que estas células podem ser crescidas e pelos mecanismos relativamente simples de reprodução e transmissão da informação genética, estas espécies tem despertado diversos interesses de pesquisas nas mais variadas áreas acadêmicas. A bactéria, Escherichia coli, por exemplo, é encontrada em várias amostras de água potável coletadas no mundo inteiro, numa proporção não aceitável para a saúde humana, o que gera uma grande preocupação. No caso, esta bactéria se divide de 20 a 30 minutos a $37^{\circ} \mathrm{C}$ num meio nutriente 
simples de glicose, sais de amônia e minerais, reproduzindo-se de forma assexuada, na qual uma célula cresce até dobrar de tamanho e dividir-se em duas células-filhas idênticas, cada uma recebendo uma cópia de material genético (DNA) da célula parental.

Para sua reprodução e funções propriamente ditas, os microrganismos devem possuir uma fonte de energia-carbono para síntese de novo material celular e elementos inorgânicos (nutrientes), tais como, nitrogênio, fósforo, potássio, cálcio e magnésio. Os nutrientes orgânicos (fatores de crescimento) são também necessários para síntese celular. Duas das mais comuns fontes de carbono celular para os microrganismos são a matéria orgânica e o $\mathrm{CO}_{2}$. Os organismos que usam o carbono orgânico para formação de tecido celular são chamados heterotróficos. Os organismos que utilizam $0 \mathrm{CO}_{2}$ são chamados autotróficos.

Esses microrganismos de estrutura simples e facilidade de reprodução possuem outra importante característica ligada a sua reprodução. A maioria das espécies de bactérias contém uma ou mais moléculas de DNA circular, chamadas de plasmídios. Essas moléculas estão livres no citoplasma celular e possuem na maioria das células, poucos genes se comparado ao cromossomo bacteriano, localizado na zona nuclear. Os plasmídios transportam informação genética e sofrem replicação produzindo plasmídios-filhos que passam para as células-filhas quando a célula se divide (LEHNINGER, 1993). Por muitas divisões celulares, os plasmídios comuns podem se destacar do DNA cromossômico, porém também podem se integrar ao DNA cromossômico ficando novamente coordenados. Alguns plasmídios transportam genes que especificam a resistência da bactéria hospedeira. As bactérias que contêm tais plasmídios são resistentes e podem sobreviver no corpo do hospedeiro mesmo depois de um tratamento com agentes antimicrobianos.

A resistência ao agente antimicrobiano pode ocorrer ou por mecanismos intrínsecos ou por mecanismos adquiridos. Resistência adquirida pode surgir ou por mutação ou pela aquisição de vários tipos de materiais genéticos na forma de plasmídios, transposons e auto-replicação de DNA extracromossômico (MCDONNELL e RUSSELL, 1999). 
A resistência adquirida para um grande conjunto de antibióticos têm sido observada em uma variedade de microrganismos. A resistência intrínseca é um fenótipo demonstrado pelo microrganismo depois do uso de agente antimicrobiano, i.e. através de uma propriedade de resistência natural do microrganismo (RUSSELL, CHOPRA, 1996). A resistência intrínseca para agentes antimicrobianos pode ser fornecida por uma série de mecanismos incluindo a natureza e a composição da parede celular da bactéria que pode agir como uma barreira permeável, assim reduzindo a síntese de compostos, e também pelas enzimas constitutivelmente sinterizadas que podem ocasionar degradação dos compostos (MCDONNELL e RUSSELL, 1999).

Biocidas (como a prata) e antibióticos tem diferentes modos de ação. Os biocidas tendem atingir múltiplos sítios dentro ou na própria célula bacteriana e portanto, ter atividade de amplo-espectro. Os antibióticos tendem atingir sítios específicos dentro ou na própria célula bacteriana e ter atividade de estreitíssimo espectro. A resistência ao anti-séptico e ao biocida pode ser adquirida por mutações em genes celulares normais, plasmídios ou transposons. A maioria dos biocidas age nos componentes da superfície celular e/ou na membrana citoplasmática. Portanto, resistência intrínseca envolveria resistência natural através da estrutura da superfície celular e sua composição química.

Há décadas, mutações cromossômicas aos antibióticos têm sido desvendadas. A resistência à $\mathrm{Ag}^{+}$determinante em Enterobacteriaceae, recentemente foi clonada e seqüenciada, mas nenhuma resistência à prata ainda foi identificada em bactéria Gram-positiva, apesar de staphylococci e outra bactéria Gram-positiva terem sido expostas aos compostos de prata no uso clínico (MCDONNELL e RUSSELL, 1999).

Resistência bacteriana aos íons de metais pesados pode resultar de sistemas de efluxo iônico dependente de menos energia do que a desintoxicação química. Em bactéria Gram-negativa, biocidas são bloqueados de alvos penetrantes na célula por uma outra membrana (OM) e a ação de mecanismos de efluxo. Com relação às (OMs), Pugsley e Schnaitman (1978) documentaram que E. coli mutantes que careciam das outras membranas 
(OMs) porosas foram mais resistentes à prata $\left(\mathrm{Ag}^{+}\right)$. Li et al. (1997) também sugeriram que a ação de efluxo pode fazer o papel principal na resistência à prata, que provavelmente, foi salientado sinergicamente de reduções na permeabilidade da outra membrana (OM). Bombas de efluxo são compostas de quaisquer proteínas como uma ATPase ou anti-carregador de cátion- ânion químico-osmótico (SILVER, 1996; SILVER, 1998; NIES, 2003), e a $\mathrm{Ag}^{+}$tem sido associada a dois destes mecanismos (GUPTA, MATSUI e LO, 1999).

Tem-se documentado que plasmídios bacterianos com resistência à prata acumulam menos prata $\left(\mathrm{Ag}^{+}\right)$do que as espécies suscetíveis (DESHPANDE, CHOPADE, 1994). Esta observação foi determinada por ser um processo de efluxo não ativo. Um plasmídio (tendo) resistência a alguns antibióticos e metais pesados, incluindo a prata $\left(\mathrm{Ag}^{+}\right)$foi obtido de uma das espécies de Salmonella isolada de uma amostra de queimadura, mas que depois causou (septicemia), morte em 3 pacientes e acabou resultando no fechamento das unidades de queimadura do Hospital Geral de Massachusetts (GUPTA, MATSUI e LO, 1999).

\subsection{COMPONENTES DO LEITE}

A Associação Brasileira de Criadores de búfalos mostrou através da Tabela 1 as principais diferenças entre a composição do leite bovino e a composição do leite de búfala:

Tabela 1 - Componentes do leite de búfala e do leite de vaca

\begin{tabular}{lcc}
\hline COMPONENTES DO LEITE & BÚFALA & BOVINA \\
Proteínas & $4,00 \%$ & $3,50 \%$ \\
Lipídios & $8,00 \%$ & $3,50 \%$ \\
Lactose & $4,90 \%$ & $4,70 \%$ \\
Água & $82,00 \%$ & $87,80 \%$ \\
Colesterol Total & $214 \mathrm{mg} \%$ & $319 \mathrm{mg} \%$ \\
\hline Fonte: ABCB - Associação Brasileira de Criadores de Búfalos - \\
\multicolumn{3}{c}{ http://www.bufalo.com.br/leite.htm. }
\end{tabular}

Os componentes do leite de búfala foi um dos mais importantes motivos que influenciaram no interesse pela pesquisa. A quantidade de lipídios, sais minerais e outros componentes do leite de búfala faz com que o crescimento 
bacteriano seja maior, quando comparado ao leite bovino.

A diretora do Centro de Organização e Assistência Laticinista (COALMG), Pautilha Guimarães depois de várias pesquisas traz a descrição dos componentes do leite, da seguinte forma:

Água: é o componente que existe no leite em maior quantidade, onde se encontram dissolvidos, sUSPensos ou emulsionados os demais componentes. A água comum é igual a água do leite em todos os sentidos. Isto é, praticamente provado quando se dissolve leite em pó na água e se obtém o leite líquido com algumas modificações pequenas nos sólidos.

Gordura: é o componente que dá ao leite cor amarelada. A gordura é um dos componentes mais ricos do leite. A matéria gorda do leite forma uma emulsão relativamente estável, constituída por glóbulos de pequenos diâmetros, bem distribuídos, no qual 1 milímetro cúbico de leite contém 1 a 5 milhões de glóbulos. Os glóbulos são cobertos por uma membrana protetora. A gordura pode ser retirada do leite por processo natural, retirando-se a nata que sobe à superfície quando o leite fica em repouso, isto porque é mais leve que os outros componentes do leite, ou pelo processo do desnate, através de máquina denominada desnatadeira. É o que se chama de desnate do leite. A gordura se separa em forma de creme.

Proteínas: as proteínas dão ao leite a cor esbranquiçada opaca. É fácil de se conhecer as proteínas do leite, pois são elas as principais formadoras de massa branca quando o leite coagula, e é manipulado para fabricar queijos. As proteínas do leite são formadas de: Caseína (maior parte); Albumina e globulina.

A caseína é formada por uma solução coloidal constituindo-se na maior parte de matéria nitrogenada do leite. É um dos componentes mais úteis do leite. Obtém-se a caseína propriamente dita: pela precipitação natural do leite, fermentação lática e pela coagulação com auxílio de coalhos (enzima) e ácidofermento lático, etc.

A albumina, denominada também de lacto-albumina, é solúvel na água, não se coagula pelo coalho, mas pelo calor e pelos ácidos. Quando se fabrica 
queijos, a albumina sai junto com o soro.

As proteínas existentes no leite apresentam-se nas seguintes percentagens médias: caseína 3,0\%, lacto-albumina 0,5\%. Estas percentagens são muito mais fixas que as referentes à gordura.

Lactose: a lactose é o açúcar do leite, sendo praticamente o único que nele existe e se apresenta no leite de todos os mamíferos. Portanto, é a responsável pelo gosto adocicado.

Sais minerais: no leite existem principalmente fosfatos, citratos, carbonato de sódio, cálcio, potássio e magnésio. A ação fisiológica dos diferentes sais do leite é importante, principalmente do fosfato de cálcio, na formação de ossos e dentes.

Vitaminas: o leite constitui uma larga fonte para fornecimento de vitaminas necessárias ao organismo. São encontradas no leite as seguintes vitaminas:

\section{- Vitamina A}

A vitamina A é relativamente abundante no leite, estritamente associada à gordura, mas o seu teor é muito variável, tendo como função básica à alimentação verde fornecida ao gado (pastagem);

\section{- Complexo B}

Vitamina B1 existe no leite em proporções variáveis, cerca de 750 miligramas por litro, os quais $75 \%$ das necessidades humanas desta vitamina.

Vitamina B2, riboflavina, desempenha papel importante nas fermentações, na produção dos aromas característicos na manteiga pela formação de diacetil, está presente no leite numa proporção em torno de $1 \mathrm{mg}$ por litro, quantidade que cobre boa parte das necessidades humanas.

Vitamina B4 desempenha ação co-fermento na fermentação lática.

Vitaminas B6 e B12 são outros componentes do complexo B presentes regularmente no leite, em quantidades que exercem um papel fisiológico importante. 
- Vitamina C

O leite constitui a fonte mais rica de vitamina $\mathrm{C}$ de origem animal, encontra-se nele na proporção de 10 a 20 mg por litro. As necessidades humanas são de 50 a 70 mg por dia.

\section{- Vitamina D}

O leite, de modo geral, não é muito rico nesta vitamina, pois contém apenas 1 a 2 miligramas por litro. Considera-se que as necessidades alimentares são de umas 10 miligramas. A irradiação do leite pelos raios ultravioleta aumenta extraordinariamente o seu teor de vitamina D, até 1.000 a 2.000 vezes.

\section{- Vitamina E}

Encontra-se associada à gordura do leite, mas em quantidade insuficiente para atender as necessidades humanas de $1 \mathrm{mg}$ diariamente.

\section{- Vitamina K}

Tem sido encontrada em quantidades variáveis, mas é comum estar presente no leite.

Sabe-se que o processamento do leite na fabricação de queijo gera um subproduto, o soro que é, na maior parte, descartado pela indústria de laticínios, apesar de ser riquíssimo em proteínas e lactose.

Para produzir o queijo, as fábricas promovem a coagulação do leite por intermédio de um tratamento térmico, que também tem a função de combater as bactérias. Após a coagulação, obtém-se a caseína, base para o preparo de derivados, e o soro. Acontece, porém, que esse aquecimento praticamente elimina a propriedade funcional da proteína do soro, situação agravada pela adição de sal no início do processo (ALVES FILHO, 2002).

Cabe ressaltar que mesmo tendo função bactericida, o manuseio e local desse soro nos laticínios nem sempre são locais estéreis e portanto, o soro de leite pode conter grande quantidade de bactérias principalmente do grupo coliforme. 
Para cada mil litros de leite utilizados na fabricação do queijo, são produzidos aproximadamente 820 litros de soro. O material tem $6 \%$ de proteínas - praticamente o dobro do leite - e 3.2\% de gorduras, açúcares e sais (REUTILIZAÇÃO DO USO DE LEITE, 2000).

Segundo ZINSLY et al. (2001) e MAUBOIS et al. (2001), o soro do leite pode ser obtido em laboratório ou na indústria por três processos principais:

a.) pelo processo de coagulação enzimática (enzima quimosina), resultando no coágulo de caseínas, matéria-prima para a produção de queijos e no soro "doce";

b.) precipitação ácida no $\mathrm{pH}$ isoelétrico (pl), resultando na caseína isoelétrica, que é transformada em caseinatos e no soro ácido;

c.) separação física das micelas de caseína por microfiltração, obtendose um concentrado de micelas e as proteínas do soro, na forma de concentrado ou isolado protéico (SGARBIERI, 2004).

\subsubsection{Microrganismos ENCONTRADOS EM LEITE}

Vários são os tipos bacterianos encontrados no leite:

\subsubsection{Bactérias psicrotróficas}

As bactérias do tipo psicrotróficas são microrganismos que se proliferam em leite refrigerado, que seria à temperatura de $4^{\circ} \mathrm{C}$ a $7^{\circ} \mathrm{C}$, mesmo sua temperatura ideal estar entre $2^{\circ} \mathrm{C}$ e $25^{\circ} \mathrm{C}$. Estas bactérias podem ser encontradas no ambiente, no solo, em equipamentos e em áreas refrigeradas. Sua velocidade de reprodução é lenta e o seu principal gênero é a Pseudomonas (BRITO et al.).

\subsubsection{Bactérias mesófilas}

As bactérias mesófilas estão presentes no leite recém-ordenhado, ou seja, proliferam-se no leite não refrigerado, à temperatura de $38^{\circ} \mathrm{C}$, porém podem se manter por muito tempo na faixa de $20^{\circ}$ à $35^{\circ} \mathrm{C}$. Estes microrganismos deterioram rapidamente o leite. As bactérias lácticas e as bactérias do grupo Coliforme são representantes das bactérias mesófilas 
(BRITO et al.).

\subsubsection{Bactérias lácticas}

As bactérias lácticas fermentam a lactose com produção de ácido láctico, sendo assim, muito eficientes para deteriorar rapidamente o leite cru, porém não causando problemas à saúde. Estes microrganismos atuam beneficamente nos processos de fermentação posteriores. Os gêneros: Lactobacillus, Lactococcus, Enterococcus e Streptococcus são representantes desta classe de bactérias.

Os gêneros Lactobacillus e Lactococcus são os principais responsáveis pela fermentação. O gênero Enterococcus é de origem intestinal, enquanto que o gênero Streptococcus é causador de mastite e processos infecciosos.

Os Streptococcus não causam problemas por ingestão, mas causam prejuízos no leite cru, provocando acidez no leite e quando em excesso podem causar prejuízos na fabricação do queijo.

\subsubsection{Grupo coliforme}

As bactérias do grupo Coliforme pertencem à família das enterobactérias e incluem vários gêneros, dentre os quais podemos citar: Enterobacter, Escherichia e Serratia. Podem ser encontrados no ambiente ou no intestino de animais de sangue quente.

As bactérias pertencentes a este grupo fermentam a lactose, na qual a fermentação pode ser classificada como ácido-mista, uma vez que produzem diversos ácidos: ácido fórmico, ácido acético, ácido propiônico, $\mathrm{H}_{2} \mathrm{~S}$ etc e também produzem gases, deteriorando o leite por acidificação.

Estes microrganismos podem contaminar o leite pasteurizado $\mathrm{e}$ derivados do leite. São importantes deteriorantes do queijo, podendo ocasionar inchaço do queijo e até mesmo deixar o queijo quebradiço. Não são originais do leite, denotando assim, uma contaminação externa. Uma das famílias mais importantes deste grupo é da Enterobactereaceae, pois incluem os gêneros patogênicos como, por exemplo, Salmonella, Yersinia e Shigella.

O grupo coliforme divide-se em dois sub-grupos: 


\section{- Grupo coliformes totais}

As bactérias pertencentes a este grupo crescem a $35^{\circ} \mathrm{C}$ e produzem gás quanto em caldo verde-brilhante. Tem origem no ambiente e sua contagem determina o grau de higiene do leite.

\section{- Grupo coliformes fecais}

As principais espécies deste grupo são: Escherichia coli (Figura 6) e Enterobacter aerogenes. Crescem a $37^{\circ}$ e produzem gás. São originárias do intestino e de contaminação por fezes. Sua contagem determina o grau de sanidade do leite, sendo essa o objetivo de estudo neste trabalho.

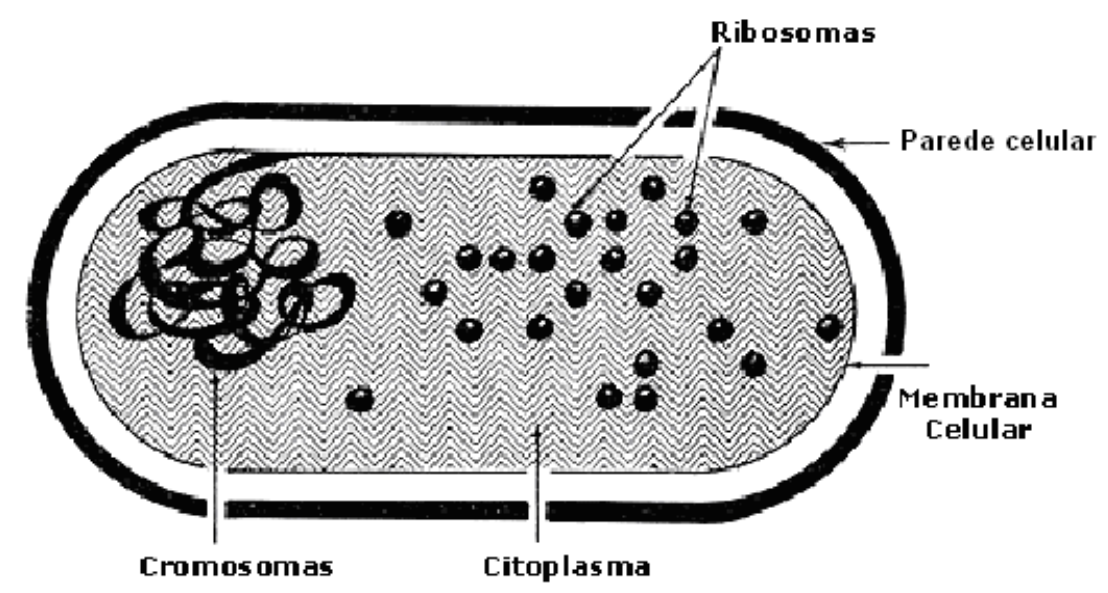

Figura 6 - Célula bacteriana de Escherichia coli. 


\section{Capítulo 3}

\section{MATERIAIS E MÉTODOS}

Apresenta-se nesse capítulo a metodologia experimental que foi estabelecida em oito fases. Essas etapas foram seqüenciadas como mostra previamente o diagrama na Figura 7.

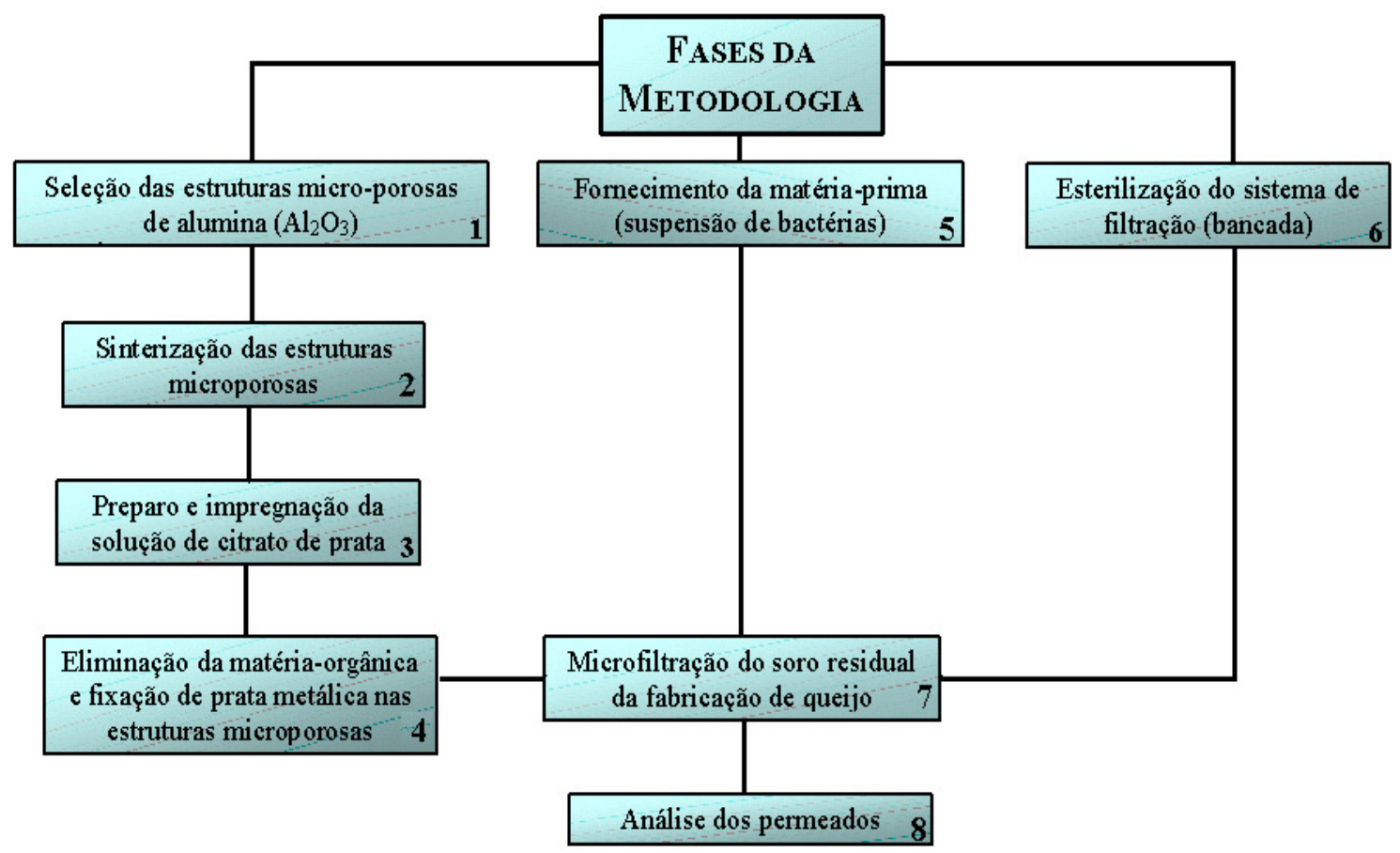

Figura 7 - Diagrama das fases da metodologia experimental

\subsection{SELEÇÃo dAS ESTRUTURAS MiCROPOROSAS}

Esta fase consistiu na escolha e preparação dos tubos microporosos de alumina e de membranas comerciais, para ensaio no processo de microfiltração. Foram selecionados os seguintes materiais tubulares com tamanho de poros sujeitos à retenção total da bactéria Escherichia coli (tubos 
microporosos de 0,4 a 0,5 $\mu \mathrm{m}$ ) e membranas "composite" próximas ao limite do tamanho da bactéria $E$. coli (de 0,8 a 1,2 $\mu \mathrm{m}$ ).

i-) tubo microporoso de alumina produzido pela Tecnicer Cetebra LTDA (São Carlos - S.P.) através da técnica de colagem e caracterizado por porosimetria de mercúrio, com tamanho médio de poros igual a $0,5 \mu \mathrm{m}$ (Figura 8 b). Este material foi extensivamente avaliado no processo de desemulsificação de água e óleo vegetal (DELCOLLE, 2005).

ii-) tubos cerâmicos microporosos de alumina produzidos pelo Laboratório de Tribologia e Compósitos (EESC/USP) através da técnica de extrusão (Figura 8 a). Neste caso os tubos sofreram ao longo da pesquisa, modificações de processamento, para alterar o tamanho de poros do produto final. A matéria-prima composta predominantemente de alumina foi misturada com diferentes concentrações de açúcar de modo a estabelecer no produto final, o tamanho de poros de diferentes tamanhos (FORTULAN et al., 2005).

iii-) membranas comerciais de origem alemã com tamanho nominal de poros igual a $0,8 \mu \mathrm{m}$ e $1,2 \mu \mathrm{m}$ (Figura $8 \mathrm{c}$ ).

Todos os tubos foram ensaiados sem impregnação e com impregnação de prata metálica, procedimento desenvolvido no Departamento de Química da Universidade Federal de São Carlos, junto ao Laboratório Interdisciplinar de Eletroquímica e Cerâmica (LIEC), sob supervisão do Prof. Dr. Elson Longo.

Os tubos produzidos por extrusão sinterizados a temperaturas diferentes no intervalo de $1400^{\circ} \mathrm{C}$ à $1450^{\circ} \mathrm{C}$, com variação na composição da mistura de barbotina, com o objetivo de definir no produto final, um meio tubular com diferentes tamanhos médio de poros.

Posteriormente, utilizando-se da técnica de porosimetria por intrusão de mercúrio fez-se a caracterização do tamanho médio dos poros dos meios microporosos. O porosimetro utilizado foi o Auto-pore II 9220, Micrometrics Instruments Corporation, disponível no Laboratório de Instituto de Física da USP de São Carlos (IFSC). 


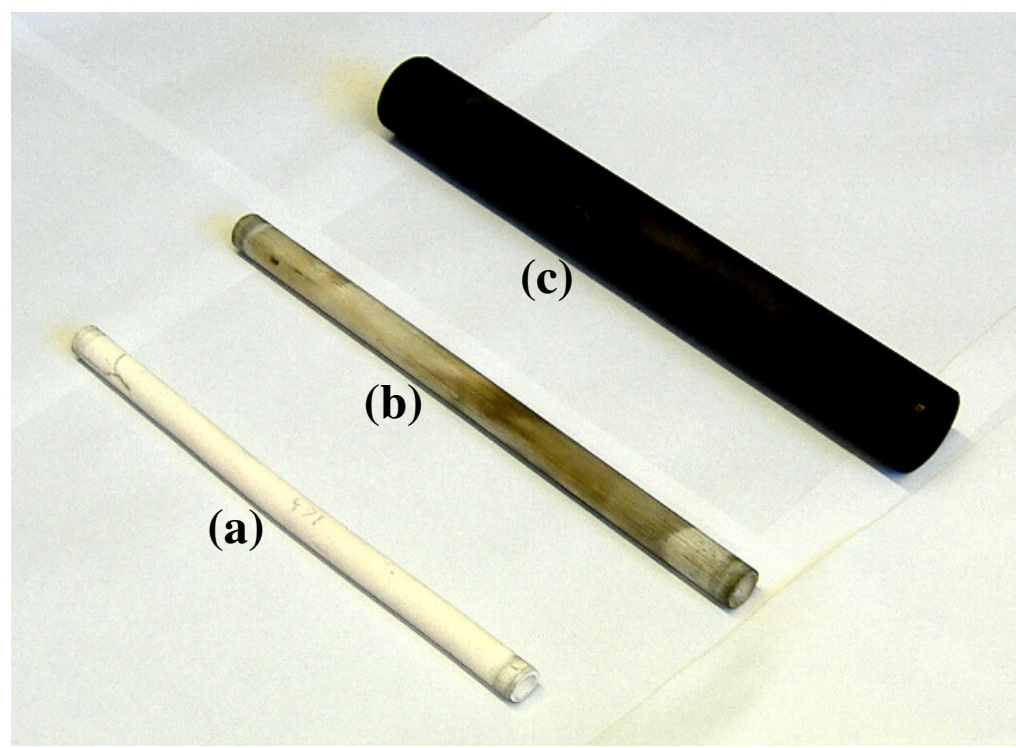

Figura 8 - (a) tubo microporoso fabricado através da técnica de extrusão (Tecnologia nacional - LTC); (b) tubo microporoso fabricado através da técnica de colagem (Tecnologia Nacional CETEBRA/TECNICER); (c) membrana comercial do tipo multi-canais (Tecnologia Alemã).

\subsection{Preparo, impregnação da solução de citrato de prata e POSTERIOR SINTERIZAÇÃO DE IMPREGNAÇÃO DAS ESTRUTURAS CERÂMICAS IMPREGNADAS}

Nesta fase foi realizado o preparo da solução de citrato de prata (Figura 9) para a devida impregnação nos tubos cerâmicos de alumina. $O$ citrato de prata foi preparado seguindo-se a proporção de 3 mols de ácido cítrico anidro $\left(\mathrm{C}_{6} \mathrm{H}_{8} \mathrm{O}_{7}\right.$ - Labsynth Produtos para laboratório P.A.-ACS) para $1 \mathrm{~mol}$ do nitrato de prata $\left(\mathrm{AgNO}_{3}\right.$ Merck 99,9\%). Nesta fase, precauções para que não houvesse a oxidação da prata foram tomadas como, por exemplo, evitar o contato da solução de citrato de prata com a luz, encapando-se o béquer onde a solução estava sendo preparada com um papel cartão preto.

Visando certificar-se de que o nitrato de prata não precipitaria na solução de água destilada + ácido cítrico $\left(\mathrm{C}_{6} \mathrm{H}_{8} \mathrm{O}_{7}\right)$, aqueceu-se a solução de citrato de prata à uma temperatura de aproximadamente $80^{\circ} \mathrm{C}$. 


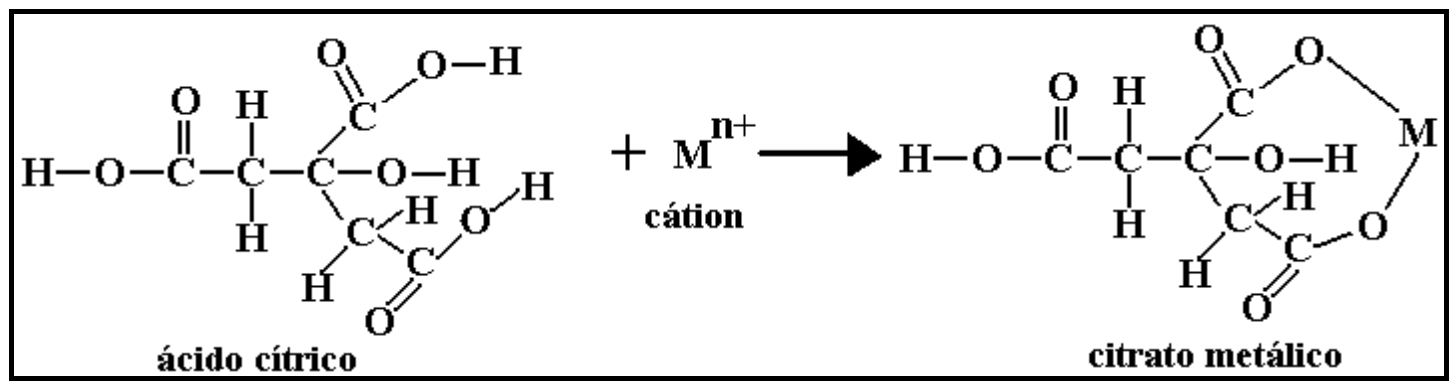

Figura 9 - Reação química do preparo de Citrato Metálico

Devido ao aquecimento da solução à $80^{\circ} \mathrm{C}$, uma parte da água evaporou, alterando-se a concentração inicial da solução de citrato de prata. Assim, foi necessário aferir a solução, colocando-se o citrato de prata em um balão volumétrico e em seguida, completando-se com água destilada até o volume inicial $(250 \mathrm{ml})$. Cabe ressaltar que para aferir, esperou-se aproximadamente uma hora para que a temperatura da solução $\left(80^{\circ} \mathrm{C}\right)$ ficasse à temperatura ambiente $\left(24^{\circ} \mathrm{C}\right)$.

Com os tubos cerâmicos pré-queimados e a solução preparada, procedeu-se para a impregnação dos mesmos. Esta impregnação foi feita através do processo de capilaridade, ou seja, colocou-se aproximadamente $5 \mathrm{ml}$ da solução em uma proveta, onde se depositou o tubo cerâmico pré-queimado, de modo que aproximadamente $1,5 \mathrm{~cm}$ do tubo cerâmico ficasse em contato com a solução durante aproximadamente 14 horas. A solução de citrato de prata durante todo este tempo foi absorvida pelos poros por capilaridade, até atingir o topo da estrutura microporosa.

Para confirmar se esta solução ácida impregnou todo o tubo, observou-

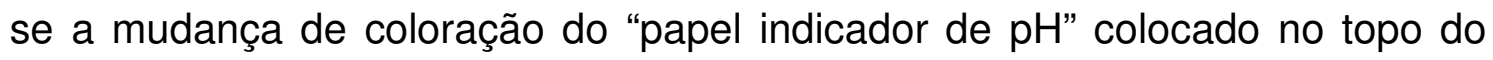
tubo cerâmico.

Após a impregnação das estruturas cerâmicas, realizou-se a queima dos tubos cerâmicos em atmosfera de nitrogênio para que se formasse prata metálica e eliminasse as possíveis impurezas e a matéria orgânica do citrato metálico.

Os patamares de temperatura utilizados nesta fase foram:

Durante 1 hora $\rightarrow 100^{\circ} \mathrm{C}$ 

Durante 1 hora $\rightarrow 200^{\circ} \mathrm{C}$
Durante 2 horas $\rightarrow 300^{\circ} \mathrm{C}$
Durante 1 hora $\rightarrow 600^{\circ} \mathrm{C}$

\subsection{FORNECIMENTO DA MATÉRIA- PRIMA}

A quinta fase desta metodologia consistiu na aquisição do leite de búfala e da água residuária (soro do leite), originária do processo de fabricação de queijo, contendo bactérias, do grupo coliforme fecal e total. Esta água residuária foi gentilmente fornecida pela Cooperativa de Laticínio (Cotilasc) da cidade de São Carlos - S.P.

A água residuária fornecida foi transportada em galões de plástico, devidamente esterilizados.

\subsection{ESTERILIZAÇÃo DO SISTEMA DE FILTRAÇÃo}

A sexta fase consistiu da esterilização de todo o sistema de filtração tangencial e inclusive da capela onde foram realizadas as filtrações.

Inicialmente, desmontou-se o sistema de filtração e lavou-se suas peças com detergente e água de torneira para remover quaisquer resíduos. Para retirar cloro, flúor e possíveis resíduos da lavagem, passou-se água destilada. Posteriormente, todas estas peças foram imergidas dentro de um recipiente contendo uma solução aquosa de água destilada + solução de formaldeído, durante aproximadamente 8 horas para uma melhor esterilização. Para enxaguar, passou-se água destilada na temperatura de ebulição (100ํㅡ). Estas peças foram deixadas dentro de um ambiente esterilizado contendo uma lâmpada fluorescente - GL - Germicida do tipo ultravioleta (15 watts, T8), que quando acesa emitia radiação ultravioleta, para evitar contaminações até o início da filtração tangencial.

Enquanto as peças ficaram imergidas na solução aquosa de formaldeído, limpou-se o ambiente de experimentação com detergente e água destilada, e em seguida, passou-se álcool (70\%). Para garantir uma melhor 
esterilização do ambiente, borrifou-se uma solução de formaldeído dentro do ambiente de experimentação e deixou-o fechado até o fim das oito horas da imersão das peças na solução aquosa de formaldeído.

Também sujeitou-se o ambiente (capela) à radiação (lâmpada de UV) constante durante uma hora para homogeneizar a esterilização.

A Figura 10a apresenta o equipamento experimental utilizado no estudo preliminar do processo de microfiltração tangencial, cujos resultados estão mostrados no Anexo C. O sistema de filtração simplificado foi montado dentro da capela e é composto por uma bomba centrífuga plástica (CP - 4R, Dancor S.A.) e conexões de PVC e inox. Nesse sistema foi possível o controle de esterilização, mas não a versatilidade para investigar a variação dos principais parâmetros, como por exemplo, pressão transmembrana, regime de escoamento e temperatura. Com a eficiente metodologia apresentada nesta bancada quanto à esterilização do sistema foi possível adaptar uma outra bancada, onde os parâmetros fluidodinâmicos puderam ser variados.

A grande maioria das análises experimentais foram controladas na bancada de ensaio apresentada na Figura 10 b. Esse sistema permite a variação da pressão transmembrana no intervalo de 1-10bar, e variação da vazão de 0-500L/h. Observa-se na Figura 10 b os principais elementos: tanque de parede dupla para armazenagem da mistura (1); bomba de deslocamento positivo de vazão e pressão (2); rotâmetro (3); módulo para instalação dos meios filtrantes (4); inversor de freqüência para controlar a rotação da bomba e sistema eletrônico com termopar para controle de temperatura através da circulação de água no tanque de parede dupla (5); reservatório e bomba centrífuga para circulação de água fria ou quente no tanque de parede dupla (6).

Um registro especial, tipo agulha, instalado no final do circuito hidráulico, foi responsável pelo controle da pressão transmembrana no módulo de filtração.

Neste sistema completamente composto de inox, foram tomados os procedimentos de limpeza e esterilização com o módulo, onde a estrutura 
cerâmica tubular era colocada, e com o circuito hidráulico antes e depois da filtração.

A limpeza do circuito hidráulico entre cada experimento foi feita submetendo-o ao seguinte procedimento: 5 minutos de água tratada para remoção do excesso de impurezas provenientes do processo de filtração com emulsões; 15 minutos com solução de detergente neutro para dissolver a matéria orgânica, principalmente gordura; 10 minutos de água tratada, trocando-a aos 5 minutos, para melhor desempenho na remoção dos resíduos.

Após a limpeza e antes da filtração, era necessária a esterilização do circuito hidráulico, seguindo-se basicamente duas etapas:

\# Circulou-se formaldeído $40 \%$ diluído em água destilada por aproximadamente 30 minutos à pressão de 5 bar, para remoção de impurezas e principalmente microrganismos;

\#Circulou-se durante 10 minutos água destilada em ebulição(100ํㄷ), para remoção do formaldeído.

Após os experimentos, as estruturas cerâmicas de alumina foram separadas do circuito hidráulico e limpas, imergindo-as em uma solução de detergente enzimático MIX UF10 da Mixing Química Ind. Com. (Santa Branca, S.P.), durante aproximadamente 8 horas. Quando tal procedimento ainda não era suficiente para a recuperação da vazão transmembrana, as estruturas cerâmicas eram aquecidas à $800^{\circ} \mathrm{C}$ para eliminação da matéria orgânica. 


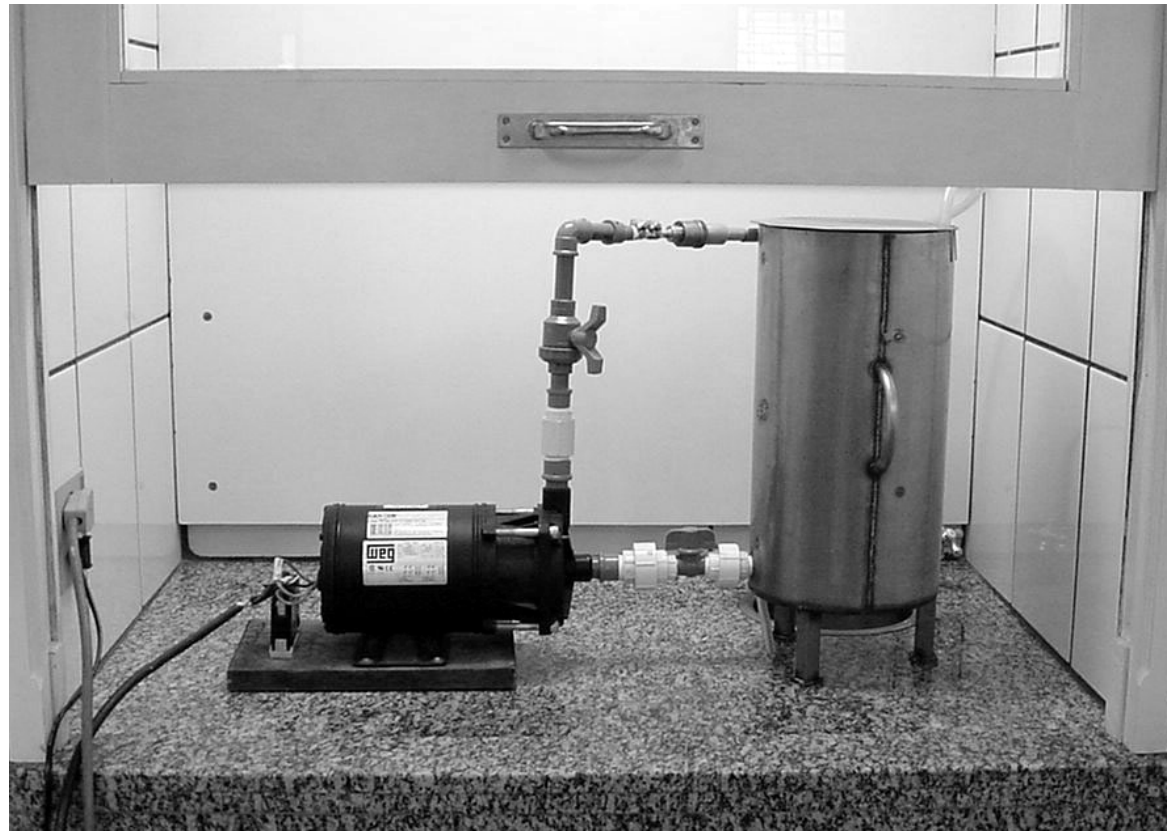

(a)

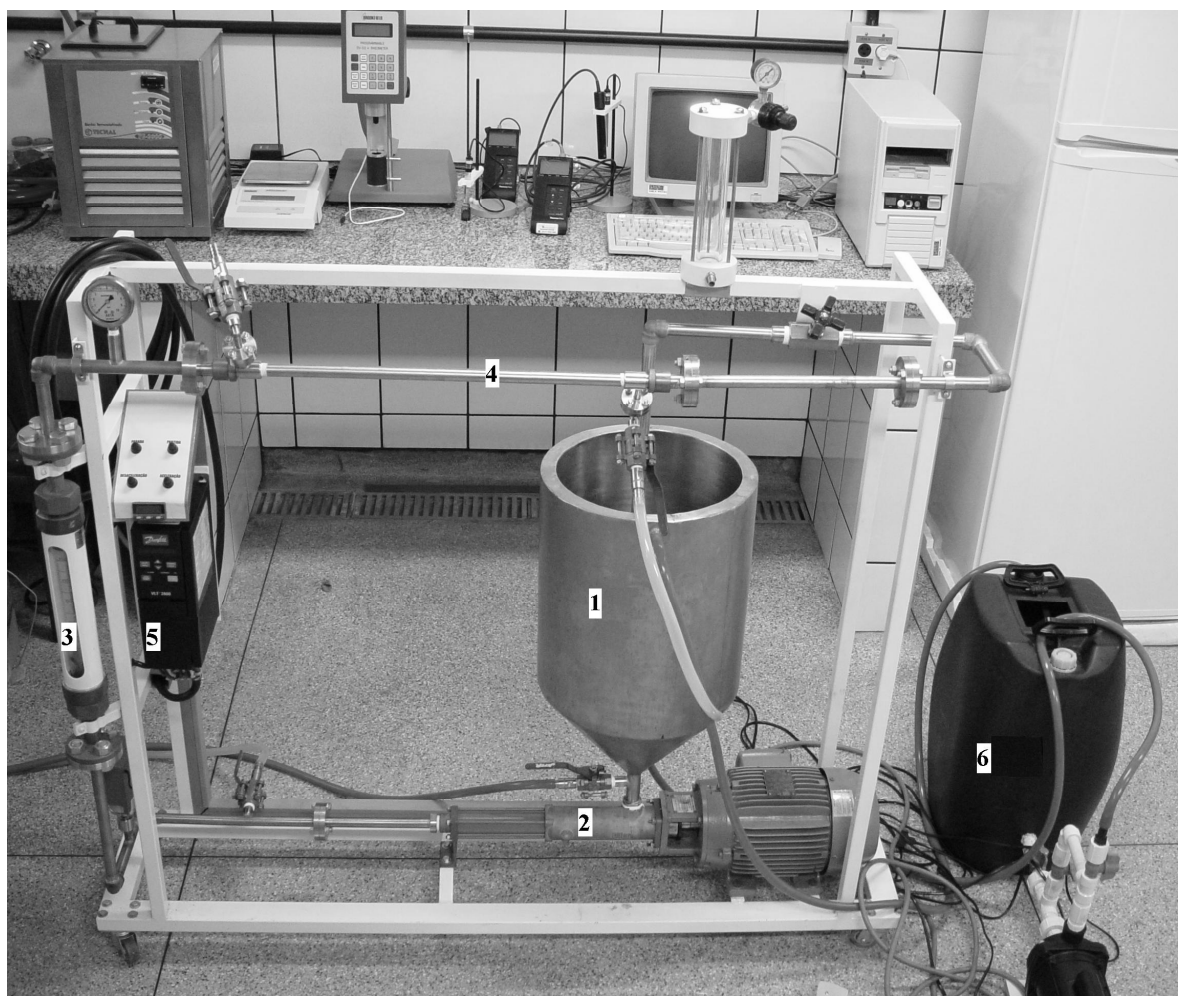

(b)

Figura 10 (a) e (b) - Fotos dos sistemas de filtração (bancada experimental) utilizados na experimentação. 


\subsection{MicrofiLtRAÇÃo do SORO DE LEITE DE BÚFALA}

A sétima fase consistiu da filtração do leite de búfala e da água residuária (soro do leite), proveniente do processo de fabricação de queijo.

Os parâmetros fluidodinâmicos e físico-químicos tais como $\mathrm{pH}$, pressão transmembrana, número de Reynolds e temperatura foram registrados no procedimento da filtração tangencial para análise do permeado.

Durante a filtração, coletou-se o permeado em diferentes instantes de tempo, de acordo com as diferentes estruturas micro-porosas ensaiadas, com o objetivo de se fazer as análises microbiológicas (contagem de coliforme fecal e coliforme total). Como base, para assegurar a presença de bactérias na suspensão residuária, a análise de microbiologia também foi realizada em uma amostra coletada antes do início da filtração.

\subsection{ANÁLISE DOS PERMEADOS}

A oitava fase consistiu da análise dos permeados.

Inicialmente, os volumes coletados de permeado foram passados por uma membrana filtrante quadriculada de nitrato de celulose, com capacidade seletiva (Figura 11a) para registro e possível contagem de coliformes. Em seguida essa membrana foi transferida para uma Placa de Petri contendo $5 \mathrm{ml}$ de ágar Chromo Cult (Figura 11b), para o crescimento dos microrganismos. Em seguida, a Placa de Petri com a membrana e o meio de cultura foram colocados na estufa de incubação à temperatura de $37^{\circ} \mathrm{C}$ durante 24 horas. Após as 24horas de incubação, pôde-se interpretar os resultados e acompanhar a redução ou aumento da quantidade de bactérias presentes no leite de búfala e na água residuária que foram micro-filtrados. No meio de cultura utilizado, as colônias de bactéria Escherichia coli ficam com coloração azul escuro, as colônias de Salmonella sp ficam com coloração azul turquesa, as colônias de coliformes totais ficam com coloração roxa e as colônias de bactérias heterotróficas ficam amareladas.

Neste trabalho não foi possível seguir o procedimento clássico de contagem de bactérias estabelecido na 20a․ Edition of the Standard Methods 
for Examination of water and wastewater, onde se faz a diluição do permeado em $100 \mathrm{ml}$ de água estéril. O principal motivo foi devido ao pequeno volume de permeado coletado na maioria dos experimentos, impossibilitando a diluição padrão para a contagem das unidades formadoras de colônias (UFC/100ml). Para se fazer a diluição, seguindo-se a metodologia estabelecida pelo "Standard of Methods for Examination of water and wastewater", seria necessário pelo menos $10 \mathrm{ml}$ de permeado. Em algumas filtrações, o volume de permeado não chegou a $5 \mathrm{ml}$ e, se caso essa diluição não fosse necessária para a identificação e contagem, não haveria como repetir esse experimento, devido ao fato de que o fluido "in natura" coletado não seria igual.

Nesse trabalho, foi feita a contagem de unidades formadoras de colônia (UFC) de bactérias na superfície da membrana de celulose na placa de Petri por grama de permeado coletado, ou seja, todo o permeado coletado no processo foi passado diretamente pela membrana e essa colocada diretamente na estufa para incubação das 24horas.

Em todos os processos de microfiltração tangencial e para cada permeado coletado nas diferentes condições de pressão transmembrana e número de Reynolds, contou-se as unidades formadoras de colônia de bactérias e dividiu-se pela quantidade em gramas do permeado. Cabe ressaltar que a quantidade de quadrados que a UFC ocupou durante o crescimento foi o número de unidades formadoras de colônias, não importando assim, o seu tamanho.

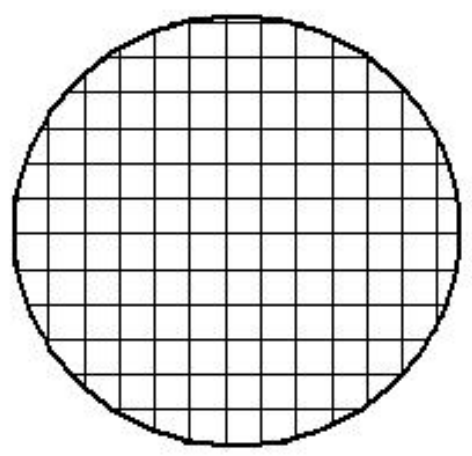

Membrana filtrante quadriculada de nitrato de celulose $-0,47 \mu \mathrm{m}$

(a)

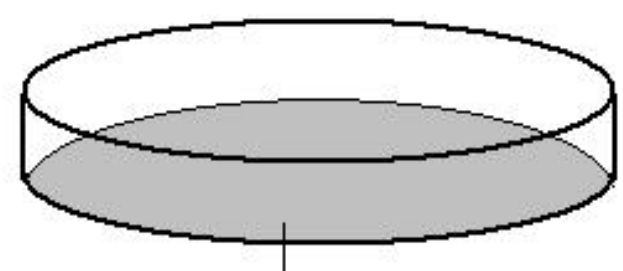

Placa de Petri com meio de cultura Ágar Chromo cult

(b)

Figura 11 - Objetos utilizados na filtração do permeado para análise microbiológica 
Para a membrana filtrante desenhada abaixo (Figura 12a) e considerando que o permeado filtrado foi de $5 \mathrm{~g}$, pode-se dizer que a contagem foi: 24 UFC/5g de coliforme fecal (E. coli -coloração azul); 8UFC/5g de coliforme total (coloração roxa) e $4 \mathrm{UFC} / 5 \mathrm{~g}$ de bactéria heterotrófica.

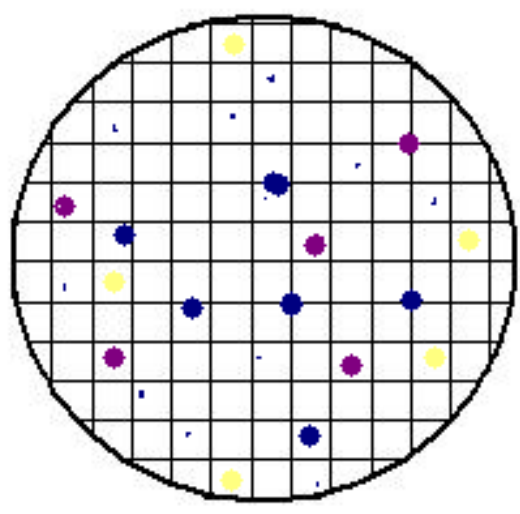

(a)

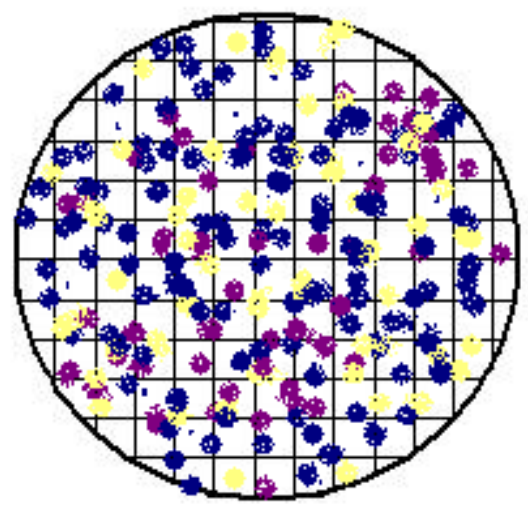

(b)

Figura 12 - Membrana filtrante com unidades formadoras de colônias (UFC) de diferentes bactérias (a); membrana filtrante com unidades formadoras de colônias em saturação (b).

A membrana filtrante apresentada no Figura 12b mostra uma membrana caracterizada saturada, ou seja, as unidades formadoras de colônias ficam sobrepostas umas às outras dificultando e impossibilitando a contagem e distinção das espécies de bactéria.

Durante 0 processo de micro-filtração foram variados parâmetros fluidodinâmicos como a pressão transmembrana e o número de Reynolds.

Os resultados foram analisados em função da vazão de permeado e correlacionados com a contagem de unidades formadoras de colônias de Escherichia coli via Placa de Petri. O objetivo foi selecionar condições fluidodinâmicas do processo de filtração que favorecesse o mecanismo de retenção.

\subsection{CÁLCULOS dOS PARÂMETROS FLUIDODINÂMICOS}

Os parâmetros fluidodinâmicos tais como: vazão transmembrana "J", número de Reynolds "Re" e resistência à formação da camada de polarização são muito importantes para a análise de experimentos da engenharia. Cada um 
destes parâmetros é calculado de uma forma específica, como poderá ser visto nos itens 3.7.1, 3.7.2 e 3.7.3.

\subsubsection{CÁlCulo da vazÃo transmembrana “J” (L/H.M²)}

A vazão transmembrana "J" na unidade L/(h. $\left.\mathrm{m}^{2}\right)$ foi calculada a partir da massa em gramas do permeado coletado, da seguinte maneira:

Por exemplo, se o permeado coletado com 5 minutos de filtração for: $4,63 \mathrm{~g} / 5 \mathrm{~min}$ - esse valor em gramas por segundo $(\mathrm{g} / \mathrm{s})$ fica: $4,63 \mathrm{~g} / 300$ seg = $0,0154333 \mathrm{~g} / \mathrm{s}$

Transformando para a unidade $(\mathrm{kg} / \mathrm{h})$ temos: $0,0154333 \times 10^{-3} \mathrm{~kg} \times 3600 \mathrm{~s}$ $=0,0556 \mathrm{~kg} / \mathrm{h}$ - esse valor quando divido pela área de filtragem na estrutura cerâmica, transforma a sua unidade para $\mathrm{Kg} /\left(\mathrm{h} . \mathrm{m}^{2}\right)$, como segue abaixo:

Área de filtragem $=\pi \times D \times L=\pi \times 0,00556 \mathrm{~m} \times 0,18 \mathrm{~m}=3,167 \times 10^{-3} \mathrm{~m}^{2}$

Sendo, "D" diâmetro interno e "L", o comprimento do tubo.

O valor 0,0556 Kg/h, pode ser transformado para 0,0556 L/h, utilizando do valor da densidade do fluido medida com picnômetro. Dividindo o valor em $\mathrm{L} / \mathrm{h}$ pela área de filtragem $\left(3,167 \times 10^{-3} \mathrm{~m}^{2}\right)$, resulta em: $17,545 \mathrm{~L} /\left(\mathrm{h} . \mathrm{m}^{2}\right)$. Em geral, todos os valores da vazão transmembrana foram calculados e são apresentados em L/(h.m $\left.{ }^{2}\right)$.

\subsubsection{CÁlculo do número de Reynolds “RE”}

O número de Reynolds é uma medida da razão entre as forças de inércia de um elemento fluido e os fluidos viscosos no elemento. O número de Reynolds será importante quando estes dois tipos de força forem relevantes no escoamento que está sendo analisado.

Osborne Reynolds (1842 - 1912) demonstrou que a combinação de variáveis podia ser utilizada como um critério para a distinção entre escoamento laminar e turbulento (MUNSON, YOUNG e OKIISHI, 1994).

No escoamento laminar, não há mistura macroscópica de camadas de 
fluido adjacentes. Um filamento fino de corante injetado em um escoamento laminar aparece como uma linha nítida; não se verifica dispersão do corante através do escoamento, exceto a lenta dispersão devido ao movimento molecular. Por outro lado, um filamento de corante injetado em um escoamento turbulento rapidamente se dispersa através do campo de escoamento; a linha de corante parte-se numa miríade de filamentos entrelaçados de corante. Este comportamento do escoamento turbulento deve-se a pequenas flutuações de velocidades sobrepostas ao movimento de corrente de um escoamento turbulento; a mistura macroscópica das partículas de um fluido de camadas adjacentes de fluido resulta na rápida dispersão do corante (FOX \& MCDONALD, 1981).

Não somente a velocidade do fluido que determina a caracterização do escoamento, mas também sua massa específica, viscosidade e tamanho do duto têm igual importância. Estes parâmetros combinados produzem o número de Reynolds.

O número de Reynolds foi calculado através da seguinte equação:

$$
\mathbf{R e}=\frac{\rho . v \cdot d}{\mu}
$$

Onde:

$\rho$ = densidade da suspensão;

v = velocidade média da corrente do fluido (suspensão) no tubo;

d = diâmetro interno do tubo;

$\mu=$ viscosidade da suspensão.

Usou-se os valores de viscosidade e densidade da água devido a composição da suspensão ser mais de 95\% água. Esses valores foram caracterizados através de medições com picnômetro e viscosímetro rotacional.

Não é possível definir precisamente as faixas de números de Reynolds que indicam se o escoamento é laminar, de transição ou turbulento. A transição real do escoamento laminar para o turbulento pode acontecer em vários 
números de Reynolds, pois a transição depende de quanto o escoamento está "perturbado" por vibrações nos condutos, da rugosidade da região de entrada etc (MUNSON, YOUNG e OKIISHI, 1994).

MUNSON, YOUNG e OKIISHI (1994) consideram que o limite para o escoamento laminar é $R e<2100$, para o escoamento turbulento é $R e>4000$ e para números de Reynolds entre estes dois limites, o escoamento pode apresentar, alternadamente e de um modo aparentemente aleatório, características laminares e turbulentas (escoamento de transição).

No processo de microfiltração tangencial, variações do número de Reynolds podem influenciar a espessura da camada limite (FOX \& MCDONALD, 1981) e conseqüentemente, a permeação na estrutura microporosa.

\subsubsection{CÁlCULO DA RESISTÊNCIA À FORMAÇÃo DA CAMADA DE POLARIZAÇÃO " $\mathbf{R}_{\mathrm{C}}$ "}

A resistência à formação da camada de polarização $\left(R_{C}\right)$ corresponde à resistência total da membrana $\left(R_{T}\right)$ menos a resistência da membrana $\left(R_{m}\right)$. Essa relação vêm da seguinte definição:

$$
R_{m}+R_{p}+R_{g}+R_{c}=R_{T} \quad \text { e } \quad R_{p}+R_{g}+R_{c}=R_{C}
$$

Sendo assim, pode-se concluir que $R_{C}=R_{m}-R_{T}$.

Para os cálculos da $R_{m}, R_{T}$ e $R_{c}$, utilizou-se a Eq. 6 (Capítulo 2), como mostra o exemplo abaixo:

$$
J=\frac{\Delta P}{\mu \cdot\left(R_{M}+R_{C}\right)}
$$

Da experimentação sabemos que:

- Fluxo do permeado para água $\left(\Delta \mathrm{P}=1,02.10^{5} \mathrm{~Pa} ; \mathrm{Re} \approx 20000\right): \mathrm{J}=$ $4,16.10^{-6} \mathrm{~m} / \mathrm{s}$;

Considerando-se $R_{C}=0$ e a viscosidade dinâmica da água ( $\mu=10^{-3}$ Pa.s) para o permeado, obtém-se o valor da $R_{M}$ : 


$$
R_{M}=2,45.10^{13} \mathrm{~m}^{-1}
$$

- Fluxo médio do permeado para o soro de leite $\left(\Delta \mathrm{P}=1,02.10^{5} \mathrm{~Pa}\right.$; $\mathrm{Re} \approx 20000$; de 0 a 25 minutos): $\mathrm{J}=3,05.10^{-6} \mathrm{~m} / \mathrm{s}$;

Dessa forma, tem-se que a resistência total da membrana quando se utilizou o soro de leite como fluido foi igual a:

$$
R_{\mathrm{T}}=3,34.10^{13} \mathrm{~m}^{-1}
$$

Esse valor $\mathrm{R}_{\mathrm{T}}=3,34.10^{13} \mathrm{~m}^{-1}$ corresponde à resistência total da membrana no intervalo de polarização não estabelecida.

- Fluxo médio do permeado para o soro de leite $\left(\Delta \mathrm{P}=1,02.10^{5} \mathrm{~Pa}\right.$; $\mathrm{Re} \approx 20000$; de 25 a 50 minutos): $\mathrm{J}=1,95.10^{-6} \mathrm{~m} / \mathrm{s}$;

Dessa forma, tem-se que a resistência total da membrana quando se utilizou o soro de leite como fluido processado foi igual a:

$$
R_{\mathrm{T}}=5,23.10^{13} \mathrm{~m}^{-1}
$$

Esse valor $\mathrm{R}_{\mathrm{T}}=5,23.10^{13} \mathrm{~m}^{-1}$ corresponde à resistência total da membrana no intervalo de polarização estabelecida.

E portanto, as resistências à formação da camada de polarização serão:

$$
\mathrm{R}_{\mathrm{C}}=\mathrm{R}_{\mathrm{T}}-\mathrm{R}_{\mathrm{m}} \quad \mathrm{R}_{\mathrm{C}}=3,34 \cdot 10^{13}-2,45 \cdot 10^{13}=8,9 \cdot 10^{12} \mathrm{~m}^{-1} \text { (polarização }
$$
não estabelecida);

$$
R_{C}=R_{T}-R_{m} \quad R_{C}=5,23.10^{13}-2,45.10^{13}=2,78.10^{13} \mathrm{~m}^{-1}
$$
(polarização estabelecida). 


\section{Capítulo 4}

\section{RESULTADOS E DISCUSSÕES}

\subsection{ANÁlises físicas para CARACTERIZAÇÃo doS tUBOS CERÂMICOS MICROPOROSOS}

Para caracterização dos meios microporosos tubulares, foram necessárias algumas análises, cujos resultados são apresentados a seguir. Através da análise de porosimetria por intrusão de mercúrio, a Figura 13 apresenta para o tubo microporoso produzido por colagem, a curva característica do tamanho médio de poros. No eixo "y" da Figura 13, são apresentados os valores da taxa de variação do volume de mercúrio $(\mathrm{Hg})$, enquanto no eixo " $x$ " são apresentados os valores do tamanho médio de poros. O "pico" na Figura 13 indica a presença de poros no meio microporoso no valor nominal igual a $0,5 \mu \mathrm{m}$, sinterizado à $1450^{\circ} \mathrm{C}$. O resultado foi confirmado com repetição para outras três amostras.

A Figura 14, apresenta a curva característica do tamanho médio de poros, resultando no valor de $0,45 \mu \mathrm{m}$, para o tubo cerâmico de alumina sinterizado à $1400^{\circ} \mathrm{C}$, confeccionado pela técnica de extrusão.

A pequena diferença observada entre 0 valor do tamanho médio de poros, $0,5 \mu \mathrm{m}$ (Figura 13) e 0,45 $\mu \mathrm{m}$ (Figura 14) pode ser atribuída à variação da temperatura de sinterização e técnica de fabricação. 


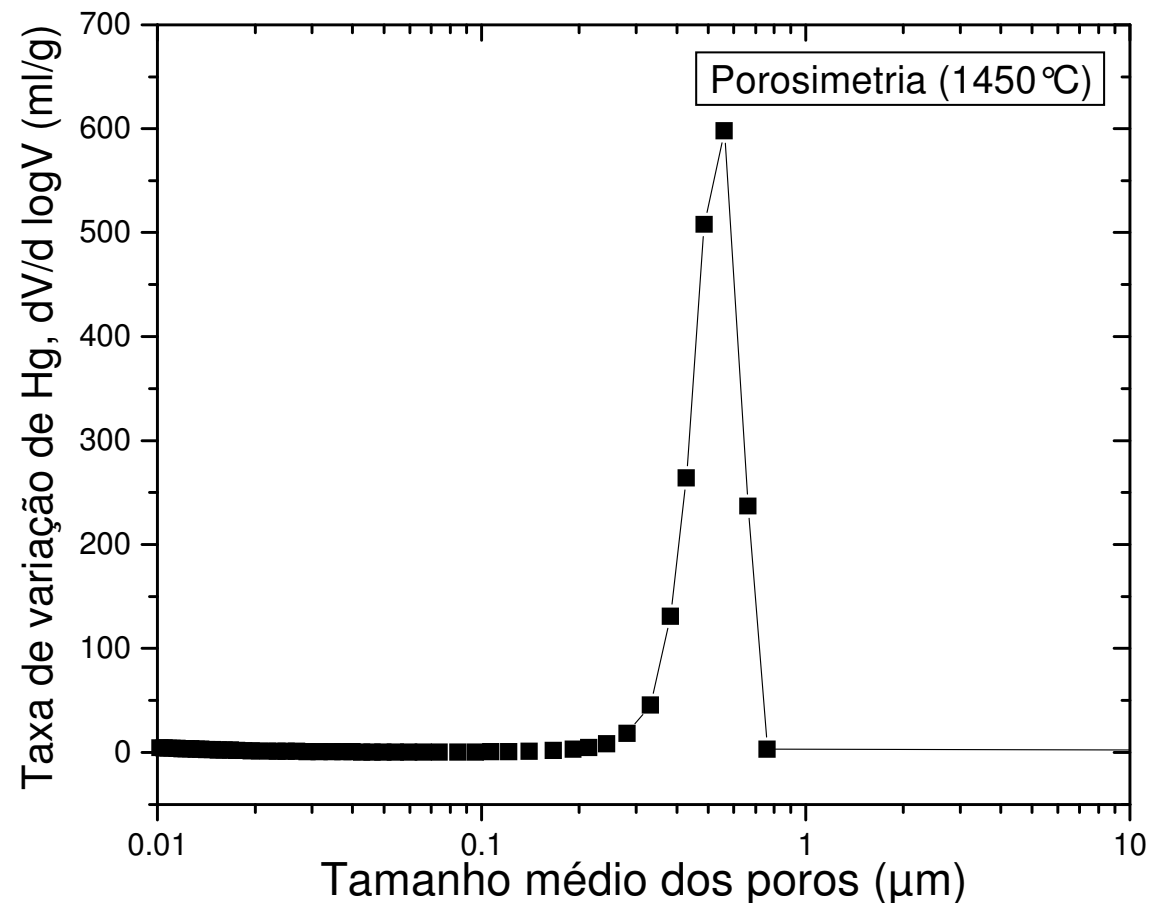

Figura 13 - Determinação do diâmetro médio dos poros do tubo cerâmico de alumina impregnado com citrato de prata e sinterizado a $1450{ }^{\circ} \mathrm{C}$.

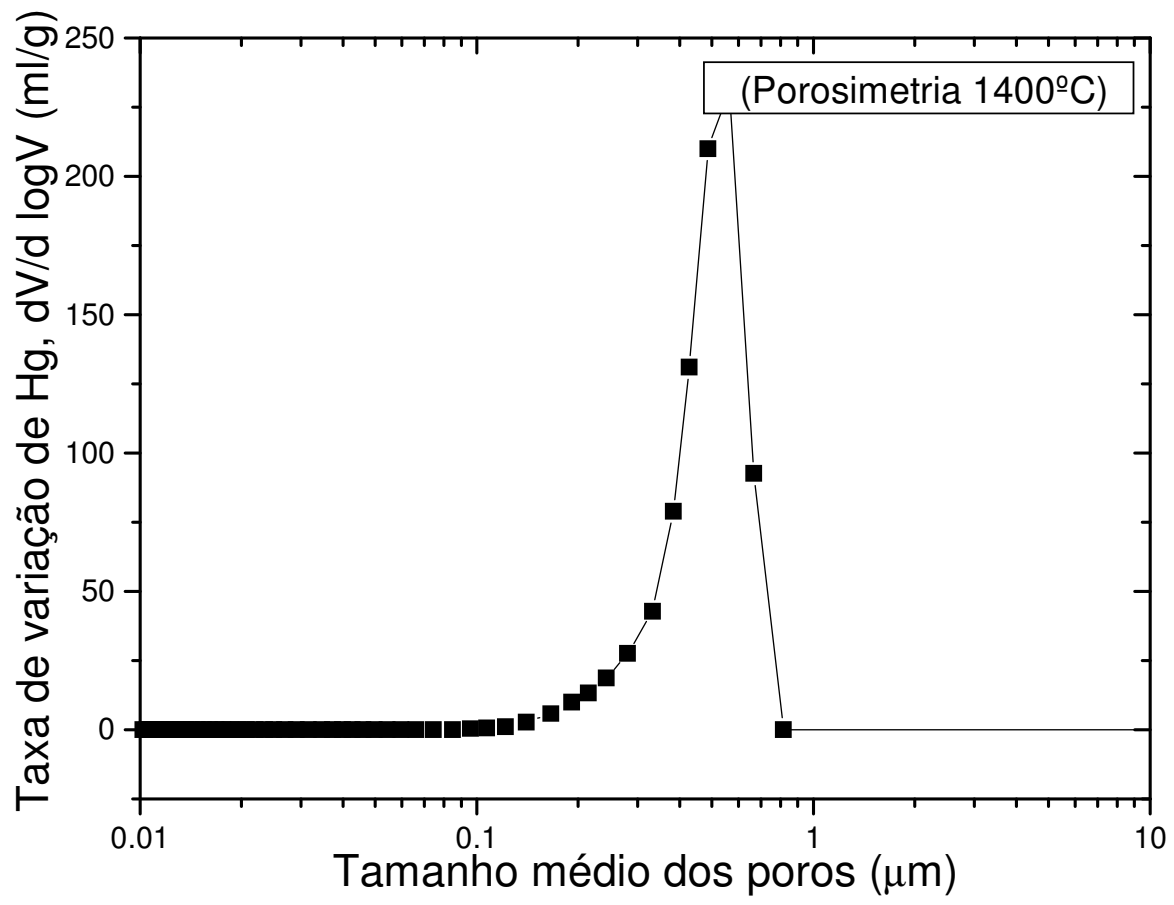

Figura 14 - Determinação do diâmetro médio dos poros do tubo cerâmico de alumina sem a impregnação do citrato de prata e sinterizado a $1400{ }^{\circ} \mathrm{C}$.

Através da análise de EDX, observou-se os principais componentes do tubo sinterizado a $1450^{\circ} \mathrm{C}$. As seguintes proporções qualitativas foram computadas: $49,93 \%$ de oxigênio, $33,41 \%$ de alumina e aproximadamente 
15,88\% de prata, observada na Figura 15.

Observa-se na Figura 16 e na Figura 17, o mapeamento por microscopia eletrônica de varredura (EDX), indicando a presença da prata no meio tubular

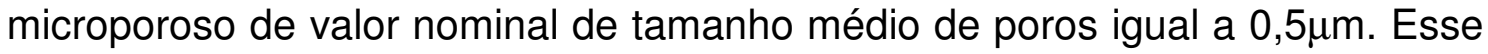
mapeamento foi feito em amostras coletadas ao longo da estrutura tubular cerâmica. Na Figura 16 observa-se uma distribuição homogênea da prata junto à alumina, enquanto na Figura 17, observa-se um aglomerado de nanopartículas de prata.

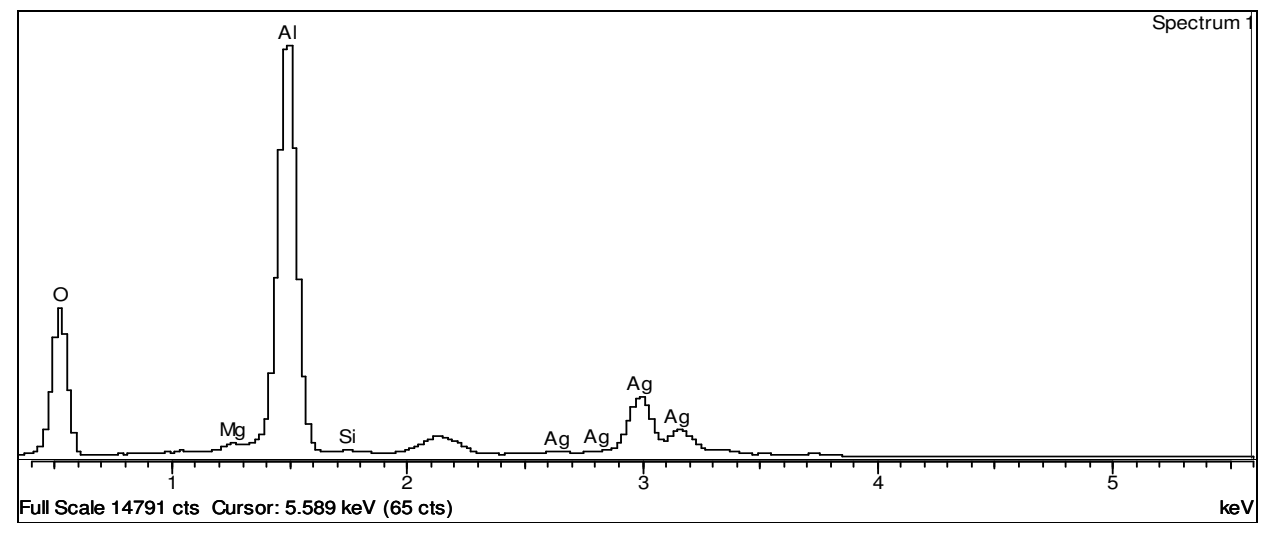

Figura 15- Distribuição dos principais componentes do tubo sinterizado à $1450^{\circ} \mathrm{C}$.

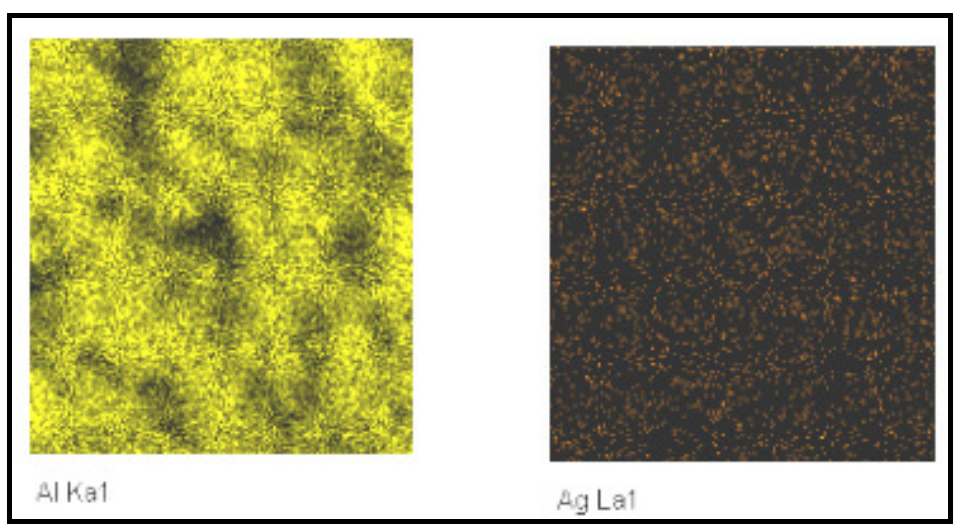

Figura 16- Mapeamento através da Microscopia Eletrônica de Varredura (MEV) mostrando a presença de alumina $\left(\mathrm{Al}_{2} \mathrm{O}_{3}\right)$ e prata $(\mathrm{Ag})$ no tubo cerâmico de $0,5 \mu \mathrm{m}$ de tamanho médio de poros 


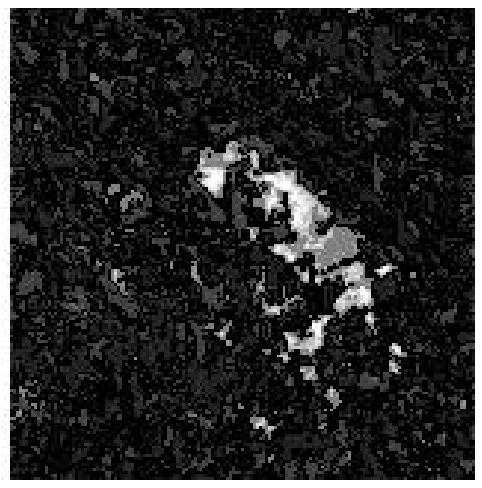

(a)

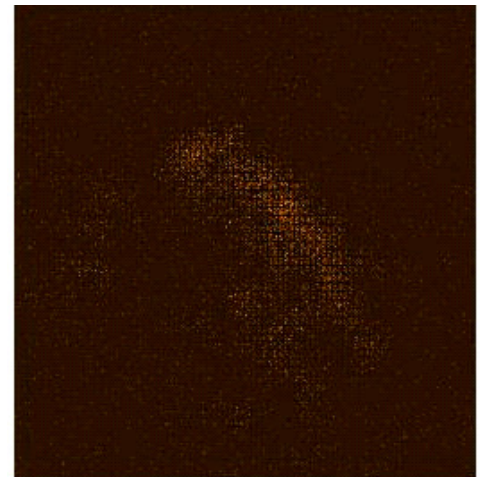

(b)

Figura 17 - (a)Imagem da morfologia do tubo cerâmico mono-poroso sinterizado à $1450^{\circ} \mathrm{C} \mathrm{e}$ impregnado com prata; (b) Mapeamento através da Microscopia Eletrônica de Varredura (MEV) mostrando a presença de prata $(\mathrm{Ag})$ no tubo cerâmico de $0,5 \mu \mathrm{m}$ de tamanho médio de poros.

A Figura 18a ilustra com a imagem produzida por microscopia eletrônica de varredura (MEV) a morfologia do tubo produzido por colagem. As manchas brancas na Figura 18a indica a presença de prata no meio microporoso.

Os meios tubulares produzidos por extrusão, puderam ser produzidos na forma de bicamada (ou membrana). Na Figura 18b, observa-se a imagem da morfologia do tubo cerâmico do tipo bicamada, obtida através da Microscopia Eletrônica de Varredura (MEV). Nota-se na morfologia da superfície (Figura 18b), duas camadas com texturas diferentes. Na região de tamanho de poros menores onde localizam-se alguns quadrados brancos, cuja análise por imagem conduz ao resultado para o tamanho de poros no valor de $0,47 \mu \mathrm{m}$.

A Figura 19 ilustra a morfologia da membrana comercial de tamanho nominal de poro igual a 1,2 $\mathrm{m}$, com a imagem produzida por Microscopia Eletrônica de Varredura (MEV). 


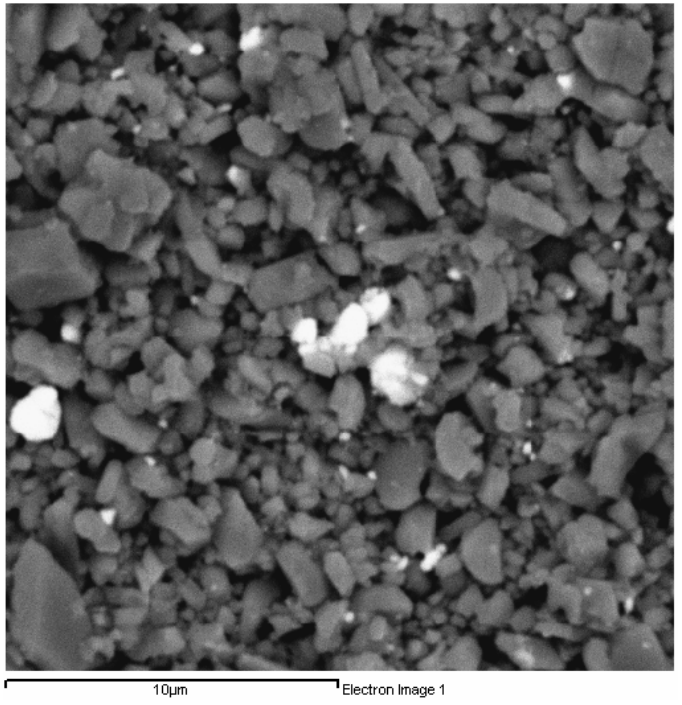

(a)

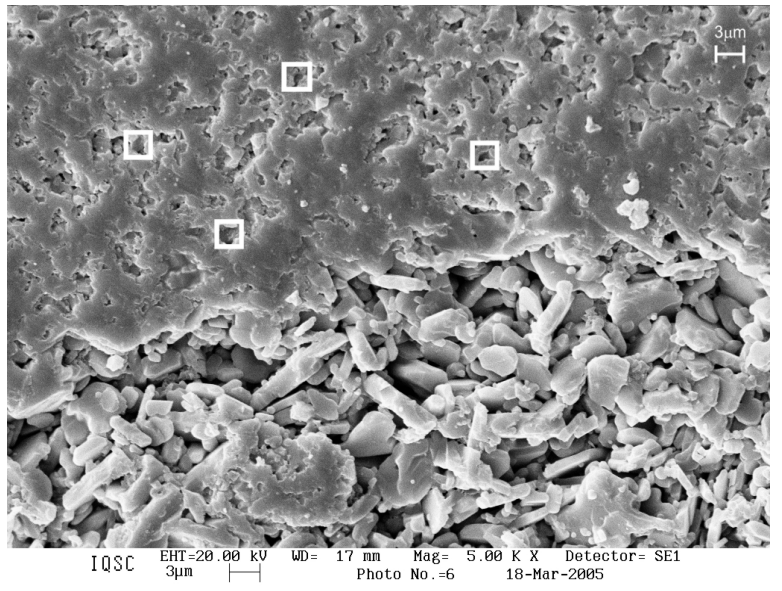

(b)

Figura 18 - Imagens da morfologia do tubo cerâmico mono-camada sinterizado a $1450^{\circ} \mathrm{C}$ e impregnado com prata (a) e imagem da morfologia de um tubo cerâmico do tipo bicamada sinterizado a $1400^{\circ} \mathrm{C}(\mathrm{b})$.

Na Figura 19a, observa-se a imagem da morfologia da camada porosa da membrana comercial, enquanto na Figura 19b estão ilustradas duas camadas com texturas diferentes, onde uma região mostra poros menores, cuja análise por imagem conduz ao resultado para o tamanho de poros no valor de $1,2 \mu \mathrm{m}$.
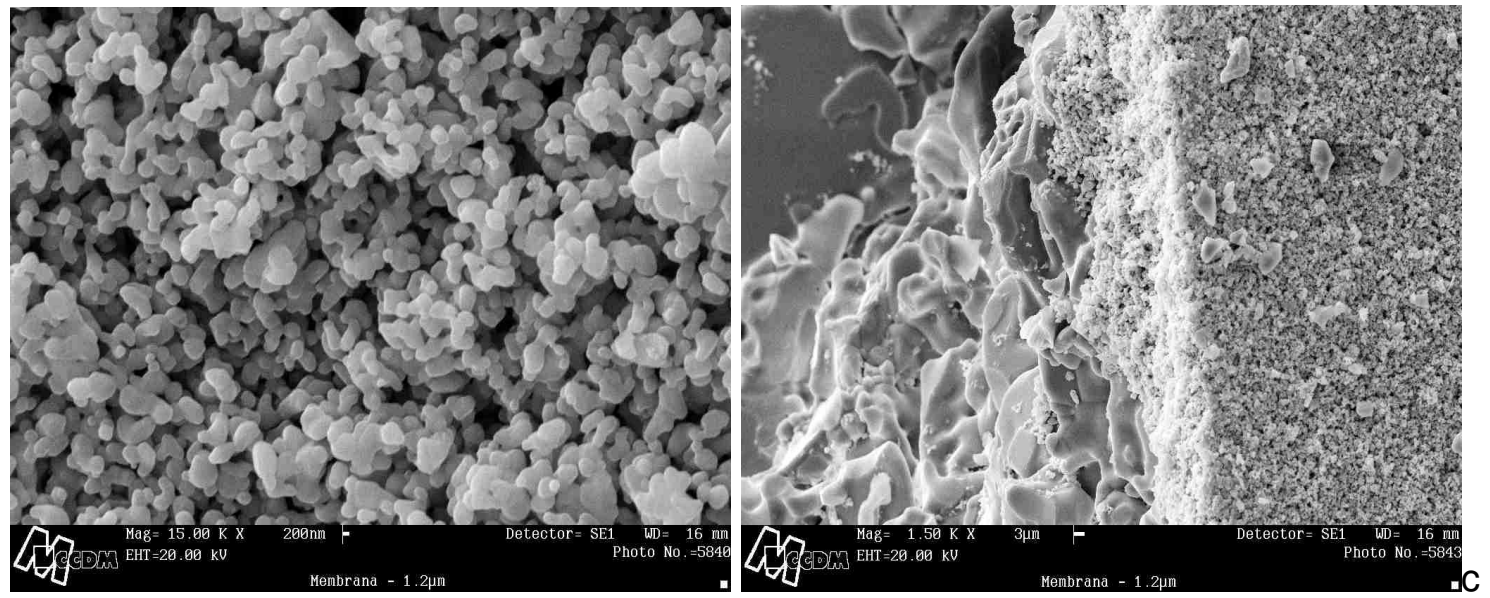

Figura 19 - Imagem da morfologia da membrana comercial de tamanho nominal de poro igual a

1,2 $\mu \mathrm{m}$, produzida por Microscopia Eletrônica de Varredura (MEV) (a); Imagem da camada microporosa de interface com a membrana de $1,2 \mu \mathrm{m}(\mathrm{b})$.

Comparando-se a Figura 18 e a Figura 19 observa-se uma semelhança relevante entre a morfologia das estruturas microporosas produzidas respectivamente com tecnologia nacional e com tecnologia importada. A 
estrutura importada contém grãos de alumina com formatos mais homogêneos, quando comparada à estrutura nacional, porém em ambas as estruturas microporosas observam-se aglomerados de grãos de alumina ao longo do tubo cerâmico.

\subsection{ANÁlise da vaZÃo transmembrana “J” (L/H.M²) DURANTE O PROCESSAMENTO}

As figuras que seguem, apresentam na forma gráfica, o comportamento da vazão transmembrana "J" (L/h. $\left.\mathrm{m}^{2}\right)$ em função do tempo de processamento em minutos.

A Figura 20 apresenta os resultados da vazão transmembrana em função do tempo para 50 minutos do processo. Os resultados são decorrentes do uso de membrana comercial de origem alemã com tamanho nominal de poro igual a $0,8 \mu \mathrm{m}$. Os experimentos foram realizados com água residuária (soro) da fabricação de queijo, e realizados com variação para a pressão transmembrana e o número de Reynolds, especificados na legenda de cada figura. Cabe ressaltar que o experimento teve duração total de 200 minutos, ou seja, não se interrompeu o processo de microfiltração ao fim dos 50 minutos da primeira para a segunda pressão a ser variada, e assim por diante.

O processo foi iniciado com a pressão transmembrana no valor de 1 bar, após 50 minutos elevada para 4 bar, após os próximos 50 minutos a pressão foi reduzida a 3 bar, e para o mesmo intervalo de tempo a pressão foi reduzida para 2 bar, encerrando uma seqüência experimental. Tal procedimento de variação foi escolhido para submeter a suspensão de bactérias à diferentes pressões.

Observa-se nas Figuras 20a, b, c e d, que à maior pressão transmembrana (4 bar), a vazão transmembrana sofre uma redução significativa a partir do início do processo, estabilizando decorrido aproximadamente 25 minutos, e na maioria dos casos mantendo com valores de "J" acima dos processos a 1, 2 e 3 bar. As variações de "J" ao longo do processo são atribuídas a não estabilização da camada de polarização. 
O comportamento mais estável e constante da vazão transmembrana ao longo do processo é observado no escoamento turbulento das Figuras 20 b, c e d $(R e \approx 30000, R e \approx 27000$ e $R e \approx 22000)$ com pressões transmembrana à 1,2 e 3 bar e indica a estabilização da camada de polarização. Nesses casos, a influência da pressão transmembrana é pouco significativa, observando pouca diferença entre os valores do fluxo transmembrana. Apenas em $R e \approx 22000$ (Figura 20d), a vazão mássica transmembrana, à 1 bar, ficou acima daquelas encontradas nas pressões de 2 e 3 bar.

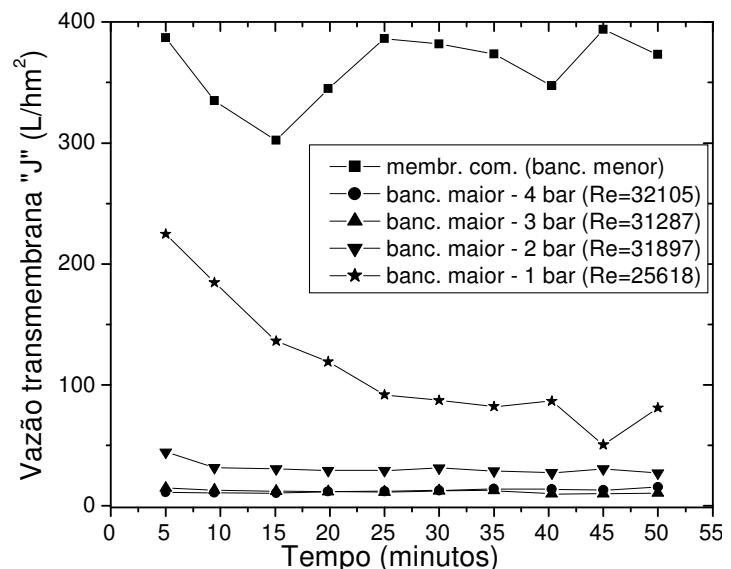

(a)

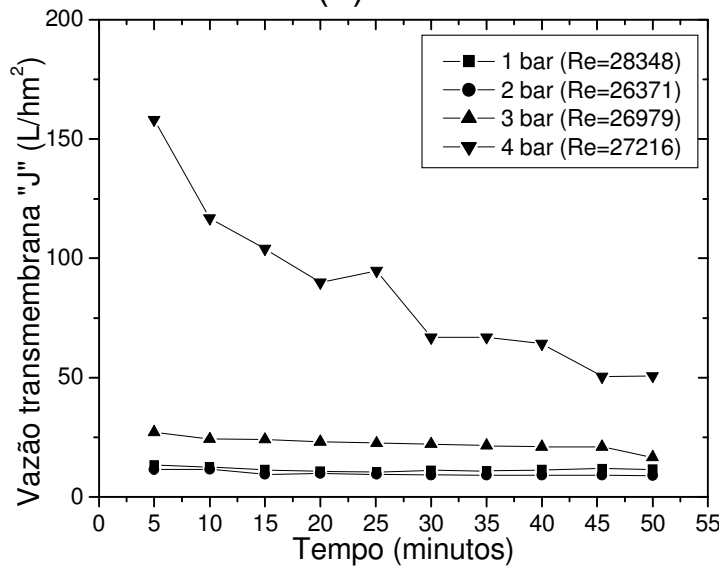

(c)

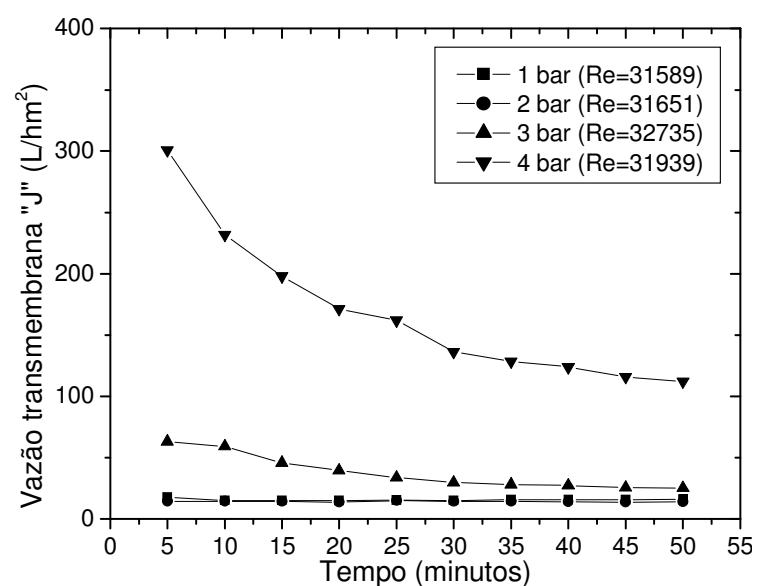

(b)

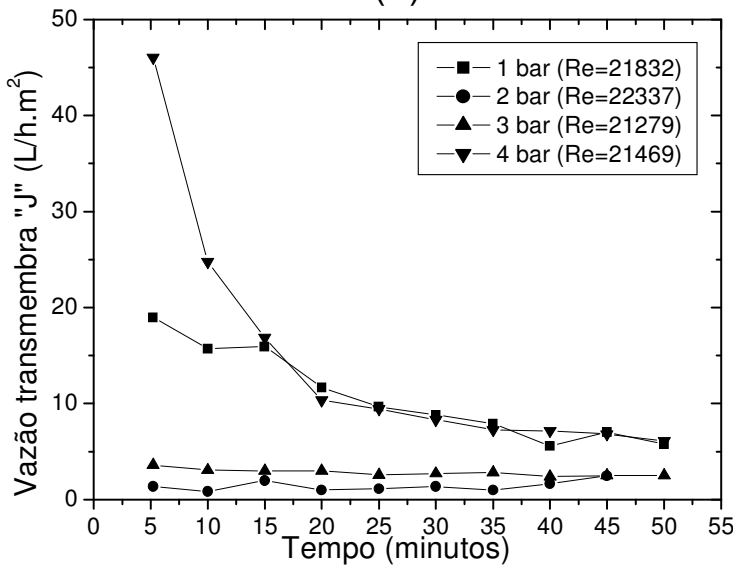

(d)

Figura 20- Gráfico da vazão transmembrana $\left(\mathrm{L} / \mathrm{h} \cdot \mathrm{m}^{2}\right)$ em função do tempo para o processo de microfiltração tangencial com membrana comercial de 0,8 $\mu \mathrm{m}$ de tamanho médio dos poros; $190 \mathrm{~mm}$ de comprimento; $5,6 \mathrm{~mm}$ de diâmetro interno, sem impregnação de prata e escoamento turbulento com $\operatorname{Re} \approx 30000$ (a) e com impregnação de prata em escoamento turbulento com

$\operatorname{Re} \approx 30000$ (b), $\operatorname{Re} \approx 27000$ (c) e $\operatorname{Re} \approx 22000$ (d).

A Figura 21 apresenta os resultados da vazão transmembrana em função do tempo para 30 minutos do processo. Os resultados são decorrentes do uso de membrana comercial de origem alemã com tamanho nominal de 
poro igual a $1,2 \mu \mathrm{m}$, sem a impregnação da prata. Os experimentos foram realizados com mesmo tipo de matéria-prima utilizada no processo com a membrana comercial de 0,8 $\mu \mathrm{m}$ de tamanho médio de poros. Esses experimentos também foram realizados com variação da pressão transmembrana e do número de Reynolds, especificados na legenda de cada figura.

O processo que teve duração de 90 minutos foi iniciado com a pressão transmembrana no valor de 1 bar, após 30 minutos do processo, essa pressão foi elevada para 3 bar e após os próximos 30 minutos, foi reduzida a 2 bar, e assim encerrando essa seqüência experimental. Tal procedimento de variação foi escolhido para submeter a suspensão de bactérias à diferentes pressões e minimizar os efeitos da camada de polarização.

Observa-se nas Figuras 21 a, b e c, respectivamente em regimes de escoamento de transição ( $R e \approx 4000, \operatorname{Re} \approx 3500$ e $R e \approx 3000$ ), que os valores da vazão transmembrana eram diretamente proporcionais à pressão transmembrana, ou seja, quanto maior a pressão transmembrana, maior a vazão transmembrana. Ao longo desses processos observam-se oscilações no fluxo transmembrana, o que indica variações na estabilização da camada de polarização na superfície da membrana.

A Figura 21b mostra valores de fluxo transmembrana mais estáveis, 0 que indica a estabilização da camada de polarização, enquanto que nas Figura 21a e c, na maior pressão transmembrana (3 bar), a vazão transmembrana sofre uma redução significativa a partir do inicio do processo, estabilizando decorrido aproximadamente 18 minutos. E em todos os casos (Figura 21a, b e c) os valores de "J" mantêm-se acima dos processos a 1 e 2 bar. Este comportamento mais estável deve-se ao tempo de uso da membrana, ou seja, a condição de $\operatorname{Re} \approx 3500$ foi a última a ser testada e portanto, os poros estavam obstruídos e a formação da camada de polarização foi maior do que nas outras condições de escoamento. 


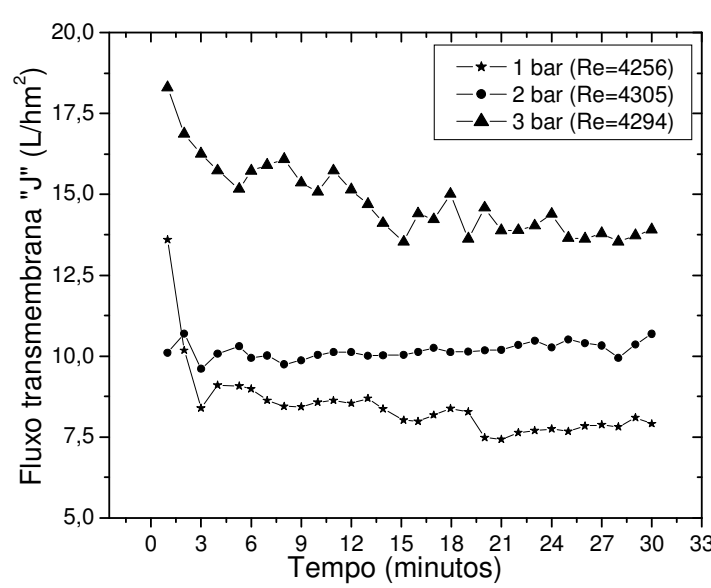

(a)

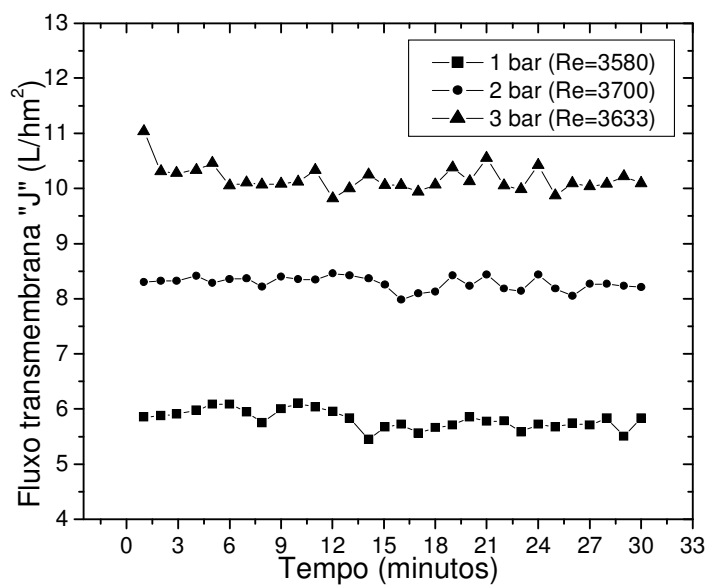

(b)

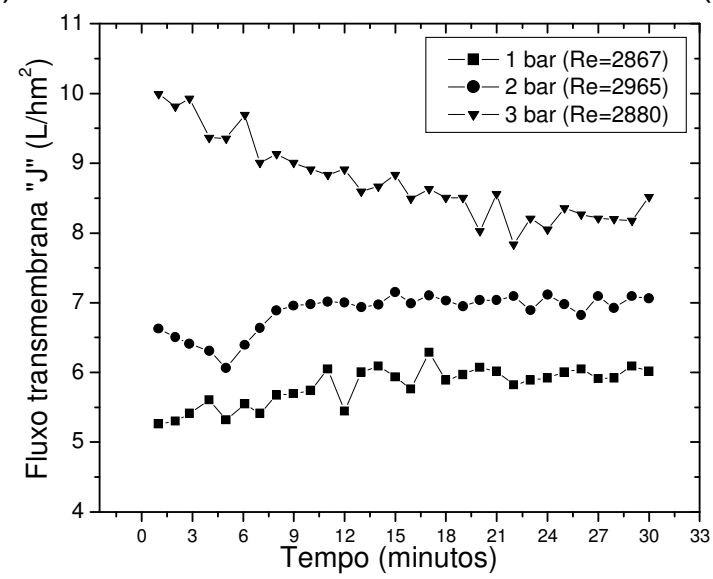

(c)

Figura 21 - Gráfico da vazão transmembrana (L/h.m²) em função do tempo para o processo de microfiltração tangencial com membrana comercial sem impregnação de prata, com 1,2 $\mu \mathrm{m}$ de tamanho médio dos poros; 400mm de comprimento; 6,0mm de diâmetro interno em escoamento de transição de respectivamente $\operatorname{Re} \approx 4000$ (a), $R e \approx 3500$ (b) e $R e \approx 3000$ (c).

A Figura 22 apresenta os resultados da vazão transmembrana em função do tempo para 30 minutos do processo. Os resultados são decorrentes do uso de membrana comercial de origem alemã com tamanho nominal de poro igual a $1,2 \mu \mathrm{m}$, com a primeira impregnação da prata. Os experimentos foram realizados com água residuária da fabricação de queijo, variando-se a pressão transmembrana e o número de Reynolds, especificados na legenda de cada figura.

O processo observado na Figura 22 seguiu a mesma seqüência de variação da pressão transmembrana e intervalos de tempo de coleta de permeado do processo descrito na Figura 21.

Na Figura 22a, em regime de escoamento de transição de $R e \approx 4000$, o 
comportamento do fluxo de permeado ao longo do processo foi semelhante para as três pressões transmembrana, observando-se uma redução na vazão transmembrana. As oscilações no fluxo transmembrana, demonstraram que não houve estabilização da camada de polarização.

Na Figura 22b e na Figura 22c, em regime de escoamento de transição de respectivamente $\mathrm{Re} \approx 3500$ e $\mathrm{Re} \approx 3000$, o fluxo transmembrana à 3 bar reduziu significativamente até aproximadamente 5 minutos. Depois apresenta valores de fluxo transmembrana estáveis, o que significa estabilização da camada de polarização. Na Figura 22b e na Figura 22c, nas pressões de 1 e 2 bar, observa que o comportamento do fluxo transmembrana manteve-se estável desde o início do experimento e com valores de fluxo transmembrana entre 5,0 e $7,5 \mathrm{~L} / \mathrm{h} . \mathrm{m}^{2}$ para o regime de escoamento de transição de $\mathrm{Re} \approx 3500$ (Figura 22b), e entre 4,0 e $6,0 \mathrm{~L} / \mathrm{h} \cdot \mathrm{m}^{2}$ para o regime de escoamento de transição de $R e \approx 3000$ (Figura 22c).

A Figura 23 apresenta os resultados da vazão transmembrana em função do tempo para 50 minutos do processo. Os resultados são decorrentes do uso de membrana comercial de origem alemã com tamanho nominal de

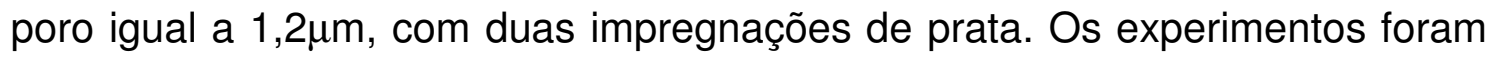
realizados com água residuária da fabricação de queijo, variando-se a pressão transmembrana e o número de Reynolds, especificados na legenda de cada figura. 


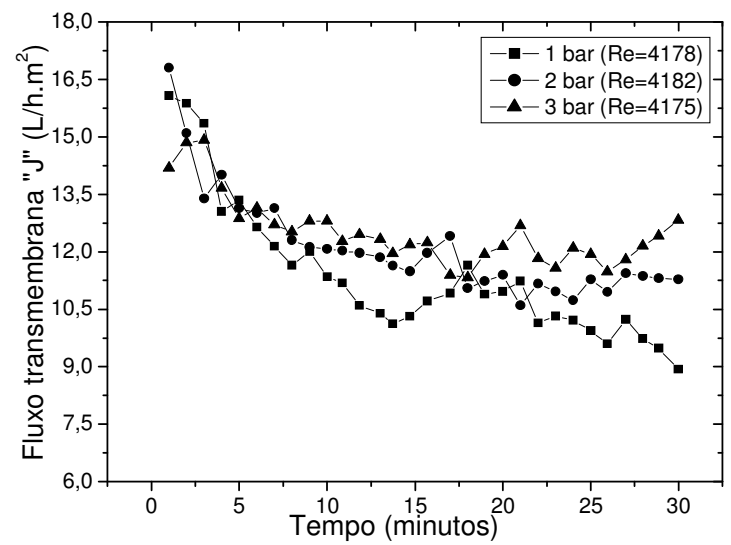

(a)

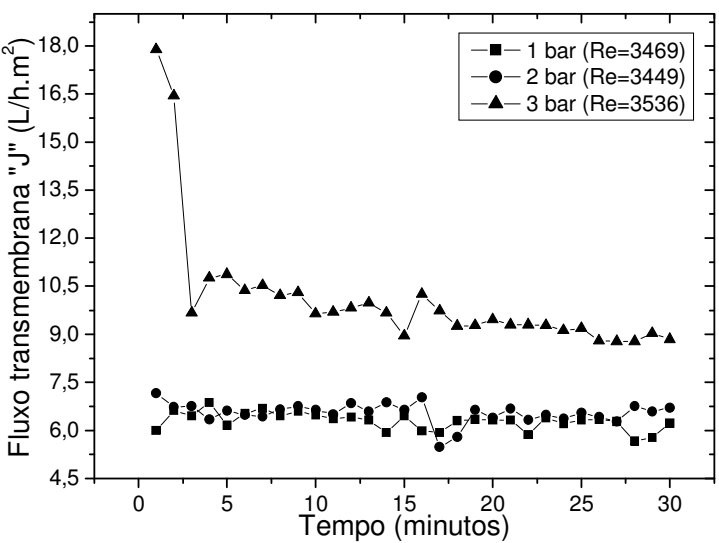

(b)

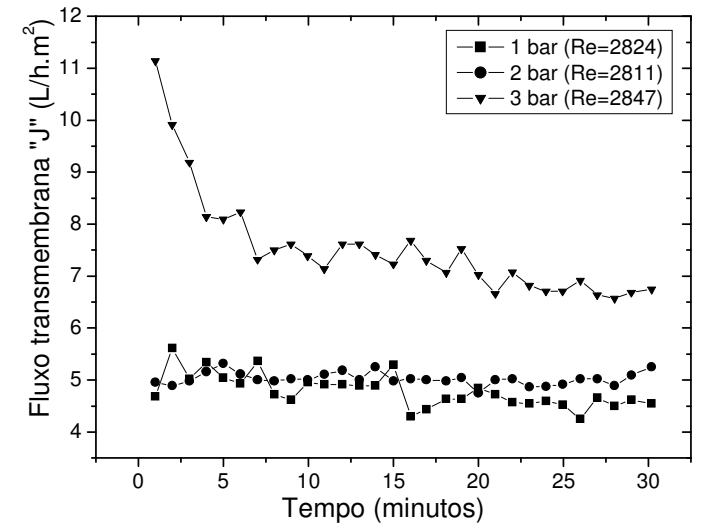

(c)

Figura 22 - Gráfico da vazão transmembrana (L/h.m²) em função do tempo para o processo de microfiltração tangencial com membrana comercial com a primeira impregnação de prata, com $1,2 \mu \mathrm{m}$ de tamanho médio dos poros; $200 \mathrm{~mm}$ de comprimento; $6,0 \mathrm{~mm}$ de diâmetro interno em escoamento turbulento de respectivamente $\operatorname{Re} \approx 4000$ (a), $\operatorname{Re} \approx 3500$ (b) e $R e \approx 3000$ (c).

O processo observado na Figura 23 seguiu a mesma seqüência de variação da pressão transmembrana e intervalos de tempo de coleta de permeado do processo descrito na Figura 21.

Na Figura 23, observa-se que nos regimes de escoamento de transição $\mathrm{Re} \approx 4000$ (a), $\mathrm{Re} \approx 3500$ (b) e $\mathrm{Re} \approx 3000$ (c), o comportamento do fluxo transmembrana ao longo do processo foi semelhante, indicando-se uma tendência de redução do fluxo seguido de uma estabilização depois de 20 minutos de experimento.

Nas Figuras 23a, b e c, observa-se que a menor vazão transmembrana foi no processo conduzido a 3bar. Essa tendência indica a estabilização da camada de polarização ao longo da superfície da membrana. 
Nas Figuras 23a, b e c, observa-se a relação entre a seqüência de variação da pressão transmembrana, a camada de polarização e o fluxo transmembrana. Como a primeira pressão a ser testada foi de 1 bar, os poros não estavam obstruídos e então, mesmo a pressão sendo baixa, a vazão mássica transmembrana em $R e \approx 3500$ (Figura 23b) e $R e \approx 3000$ (Figura 23c) foi maior que 4 bar. Só não foi maior na condição de $R e \approx 4000$ (Figura 23a), pois foi a última condição de escoamento a ser testada, e conseqüentemente, os poros estariam mais obstruídos.

A segunda pressão a ser testada foi 2 bar em todos os regimes de escoamento $\mathrm{Re} \approx 4000$ (Figura 23a), $\mathrm{Re} \approx 3500$ (Figura 23b) e $\mathrm{Re} \approx 3000$ (Figura 23c). Na Figura 23a, os poros estavam menos obstruídos, devido ao tempo de processamento da membrana, no qual observa-se um alto valor do fluxo transmembrana. Como a membrana já havia sido utilizada durante 50 minutos no experimento de $\mathrm{Re} \approx 4000$ (Figura 23a), à $\mathrm{Re} \approx 3500$ (Figura 23b) e $\mathrm{Re} \approx 3000$ (Figura 23c), o fluxo transmembrana reduziu, porém observa-se o mesmo comportamento de redução seguida de estabilidade após 20 minutos.

Quando se eleva a pressão para 4 bar, observa-se que a vazão mássica foi alta em todos os regimes de escoamento de tansição $\operatorname{Re} \approx 4000$ (Figura 23a), $R e \approx 3500$ (Figura 23b) e $R e \approx 3000$ (Figura 23c), apesar da formação da camada de polarização. Isto ocorre porque com a elevação da pressão transmembrana, partículas existentes na superfície da membrana, são carregadas, ocorre a desestabilização da camada de polarização e a passagem de fluido é favorecida.

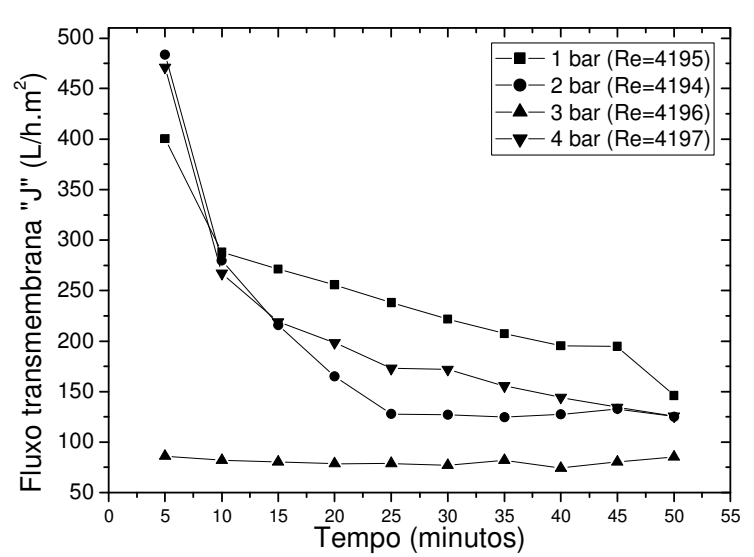

(a)

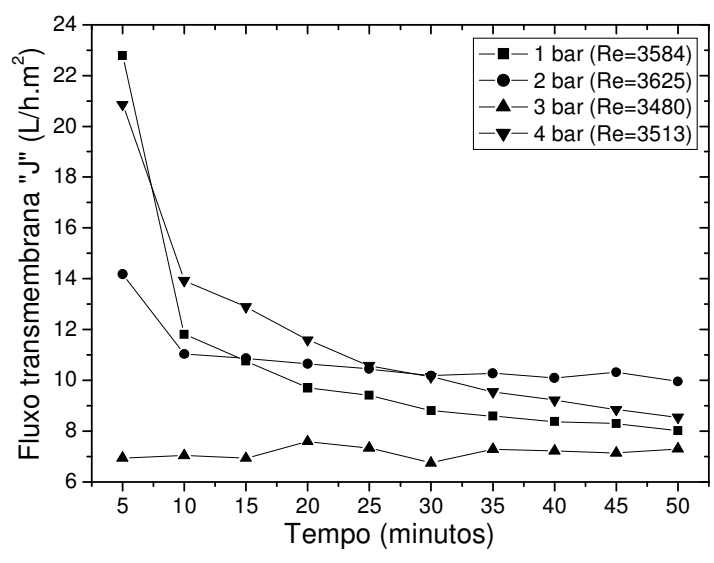

(b) 


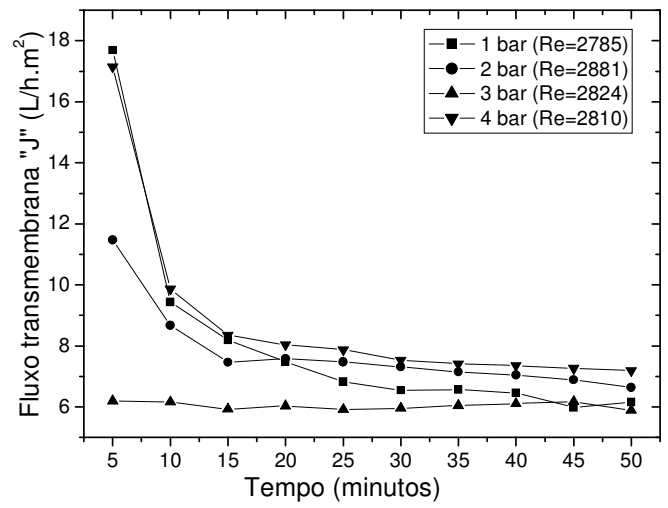

(c)

Figura 23- Gráfico da vazão transmembrana (L/h.m $\left.{ }^{2}\right)$ em função do tempo para o processo de microfiltração tangencial com membrana comercial com a segunda impregnação de prata, com $1,2 \mu \mathrm{m}$ de tamanho médio dos poros; $200 \mathrm{~mm}$ de comprimento; $6,0 \mathrm{~mm}$ de diâmetro interno em escoamento de transição de respectivamente $R e \approx 4000$ (a), $R e \approx 3500$ (b) e $R e \approx 3000$ (c).

A Figura 24 apresenta os resultados da vazão transmembrana em função do tempo para 50 minutos do processo. Os resultados são decorrentes do uso de tubo cerâmico de alumina com tamanho nominal de poro igual a $0,4 \mu \mathrm{m}$, produzidos pela técnica de extrusão. Os experimentos foram realizados com água residuária da fabricação de queijo, e foram realizados com variação para a pressão transmembrana e o número de Reynolds, especificados na figura.

O processo foi iniciado com a pressão transmembrana no valor de 1 bar, após 50 minutos elevada para 2 bar, posterior a 50 minutos a pressão foi elevada para 4 bar, e para o mesmo intervalo de tempo, a pressão foi reduzida a 3 bar para decorrer os próximos 50 minutos de processo, encerrando a seqüência experimental. Esse procedimento de variação de pressão foi escolhido para submeter a suspensão de bactérias à diferentes pressões, minimizar e promover a estabilização da camada de polarização.

Na Figura 24a, a vazão transmembrana à 2 bar superou o fluxo transmembrana à respectivamente 1 bar e 3 bar. $O$ fluxo transmembrana à 1 bar ser maior do que à 3 bar, deve-se a seqüência do experimento, no qual primeiro testou-se a pressão transmembrana de 1 bar, seguida de 2 bar e posteriormente 4 bar e por último à 3 bar. Neste caso, foi a primeira vez que 0 
tubo cerâmico estava sendo utilizado então, pode-se dizer que o fluxo transmembrana teve relação direta com a pressão transmembrana, ou seja, quanto maior a pressão transmembrana, maior o fluxo de permeado. Como à 3 bar foi a última pressão transmembrana a ser testada, prevaleceu a formação da camada de polarização e conseqüente obstrução dos poros, assim a vazão transmembrana foi a menor.

Nas Figuras 24a, b e c, observa-se que a vazão mássica à 4 bar é maior do que nas demais pressões transmembrana. O comportamento do fluxo transmembrana ao longo do processo foi de redução e com tendência de estabilização após os 25 minutos, devido à formação da camada de polarização.

Nas Figuras 24b e c, com respectivamente $R e \approx 20000$ e $R e \approx 17000$, como a membrana já havia sido utilizada e provavelmente vários poros já estariam obstruídos, a vazão mássica à 2 bar foi menor que a última pressão testada (3 bar). Também se pode dizer que a vazão transmembrana à 2 bar foi menor que à 3bar porque é um valor de pressão que reduz a força motriz responsável pelo fluxo de fluido na membrana.

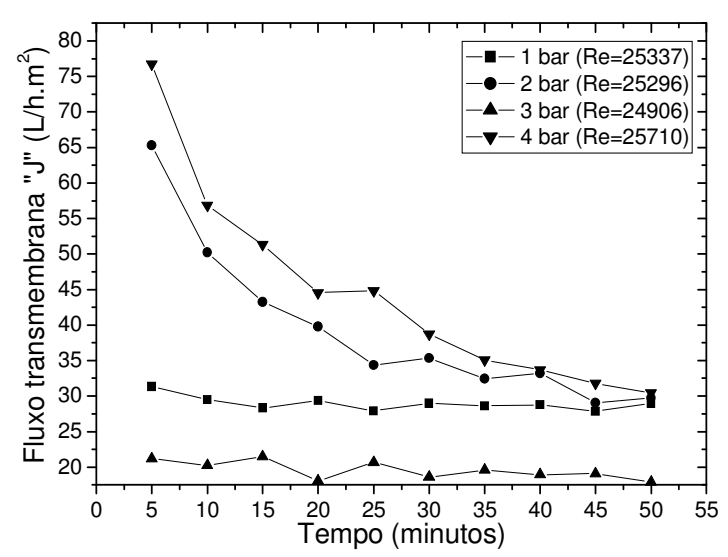

(a)

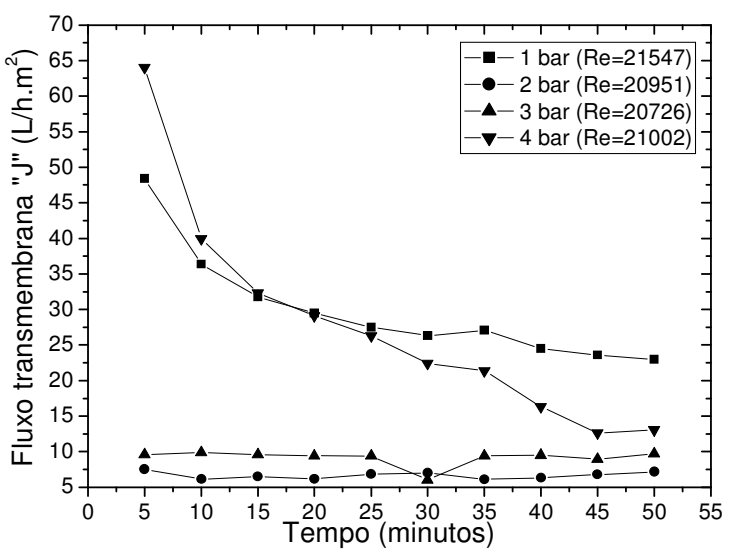

(b) 


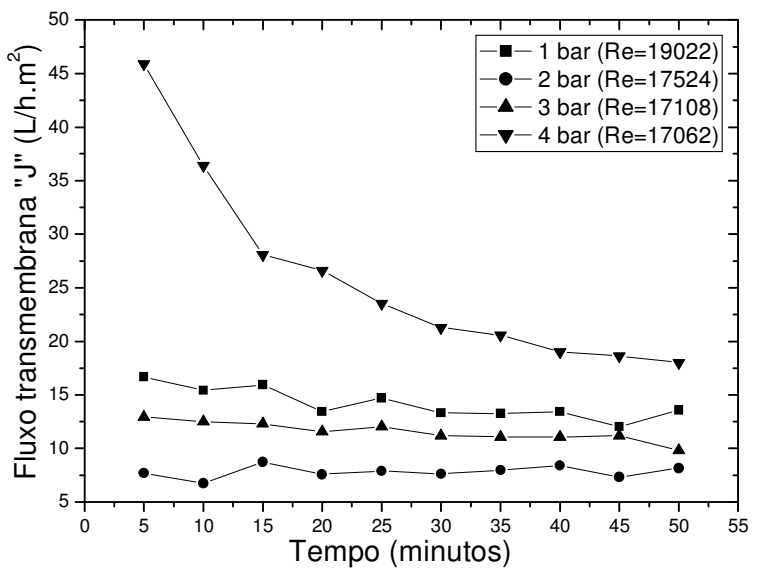

(c)

Figura 24- Gráfico da vazão transmembrana $\left(\mathrm{L} / \mathrm{h} \cdot \mathrm{m}^{2}\right)$ em função do tempo para o processo de microfiltração tangencial com tubo cerâmico sem impregnação de prata, com $0,4 \mu \mathrm{m}$ de tamanho médio dos poros; $170 \mathrm{~mm}$ de comprimento; 7,0mm de diâmetro interno em escoamento turbulento de respectivamente $R e \approx 25000$ (a), $R e \approx 20000$ (b) e $R e \approx 17000$ (c).

A Figura 25 apresenta os resultados da vazão transmembrana em função do tempo para 50 minutos do processo. Os resultados são decorrentes do uso de tubo cerâmico de alumina, produzidos pela técnica de colagem, com tamanho nominal de poro igual a $0,5 \mu \mathrm{m}$. Os experimentos foram realizados com água residuária da fabricação de queijo, e foram realizados com variação para a pressão transmembrana e o número de Reynolds, especificados na figura.

O processo foi iniciado com a pressão transmembrana no valor de 1 bar, após 50 minutos elevada para 4 bar, posterior a 50 minutos, a pressão foi reduzida para 3 bar, e para o mesmo intervalo de tempo, a pressão foi reduzida a 2 bar para decorrer os próximos 50 minutos do processo e encerrar a seqüência experimental. Esse procedimento de variação de pressão foi escolhido para submeter a suspensão de bactérias à diferentes pressões, minimizar e promover a estabilização dos efeitos de polarização.

Nas Figura 25a, b e c, respectivamente com regimes de escoamento turbulento $\mathrm{Re} \approx 21000, \mathrm{Re} \approx 18000$ e $\mathrm{Re} \approx 15000$, a maior vazão mássica transmembrana foi observada na condição de maior pressão transmembrana (4 bar). Isto ocorre devido à alta pressão transmembrana que promove o transporte de fluido pela superfície da membrana. Com exceção do 
comportamento observado na Figura 25a, a segunda maior vazão transmembrana dos experimentos ocorreu à 1 bar.

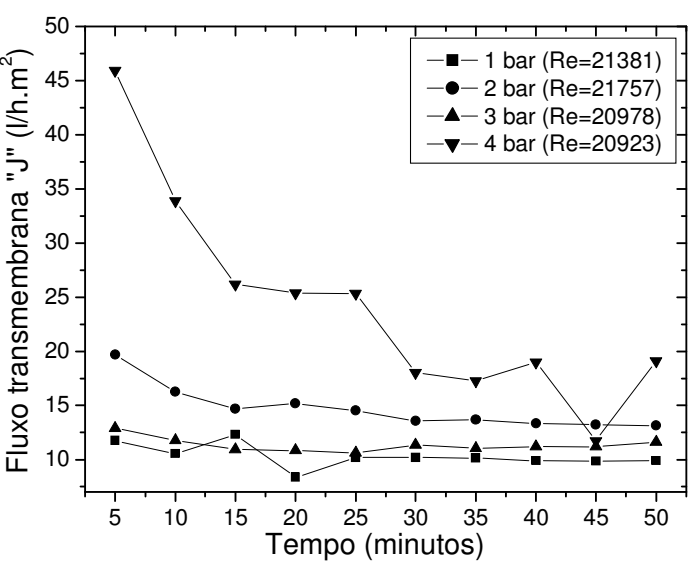

(a)

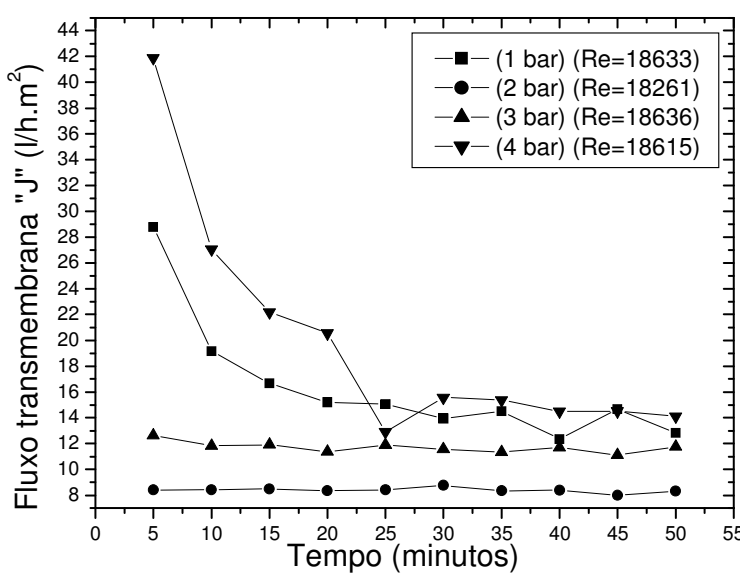

(b)

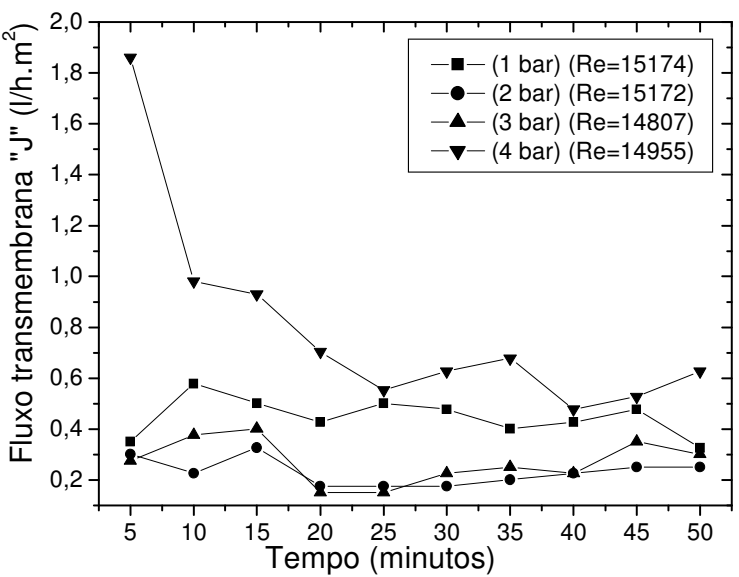

(c)

Figura 25- Gráfico da vazão transmembrana $\left(\mathrm{L} / \mathrm{h} \cdot \mathrm{m}^{2}\right)$ em função do tempo para o processo de microfiltração tangencial com tubo cerâmico sem impregnação de prata, com 0,5 $\mu \mathrm{m}$ de tamanho médio dos poros; $190 \mathrm{~mm}$ de comprimento; 8,0mm de diâmetro interno em escoamento turbulento de respectivamente $R e \approx 21000$ (a), $R e \approx 18000$ (b) e $R e \approx 15000$ (c).

Nas Figuras 25a, b e c, observa-se algumas instabilidades no fluxo transmembrana à 1 e 4 bar, devido a não estabilização da camada de polarização.

Na Figura 25a, a vazão transmembrana, à 2 bar, foi a segunda maior, pois a superfície não estava completamente obstruída. E também era a primeira fase do processo com o tubo cerâmico.

Nas Figuras 25b e c, com regimes de escoamento turbulento de respectivamente $R e \approx 18000$ e $R e \approx 15000$, observa-se que a vazão mássica à 2 bar é menor que à 3 bar, devido a menor pressão transmembrana ocasionar a 
passagem mais lenta do fluido no tubo microporoso. Ao longo do processo, observa-se que o fluxo transmembrana manteve-se constante à 2 e 3 bar, o que indica estabilização na camada de polarização.

\subsection{ANÁlise do fluXo tRansmembrana (L/H.M ${ }^{2}$ ) EM FUnÇÃo da PRESSÃO TRANSMEMBRANA (BAR)}

Da Figura 26 à Figura 31 são apresentados resultados da vazão transmembrana para o intervalo de 1 à 4 bar.

$\mathrm{Na}$ Figura 26, os resultados são decorrentes do uso de membrana comercial de origem alemã com tamanho nominal de poro igual a $0,8 \mu \mathrm{m}$. Os experimentos foram realizados com água residuária da fabricação de queijo, com coleta de permeado de cinco em cinco minutos e variando-se o número de Reynolds. A seqüência da variação da pressão transmembrana na Figura 26 foi a mesma descrita na Figura 20.

Observa-se nas Figuras 26a, b e c, que os valores da vazão transmembrana foram muito próximos no processo à 1 bar e 2 bar de pressão transmembrana, ou seja, o fluxo transmembrana no início (5minutos) e no final (50 minutos) de cada experimento e a cada pressão ficaram constantes.

Na Figura 26a e na Figura 26d, observa-se que o fluxo transmembrana ficou constante desde o início (5minutos) do processo à 3 bar, porém observase que a vazão transmembrana foi maior do que à 2 e 1 bar. Analisando a Figura 26b e a Figura 26c, faz-se a comparação dos processos, respectivamente, para com a membrana impregnada com prata $(R e \approx 30000)$ e com a membrana sem impregnação de prata $(R e \approx 25000)$. Observa-se que 0 fluxo transmembrana foi maior à 3 bar em relação as menores pressões transmembrana, e nota-se que do início do processo (5 minutos) até o fim (50 minutos), a vazão transmembrana sofreu redução, provavelmente devido a formação da camada de polarização, porém a camada de polarização não influencia no fluxo transmembrana ao longo do tempo para as pressões de $1 \mathrm{e}$ 2 bar para números de Reynolds maiores. 


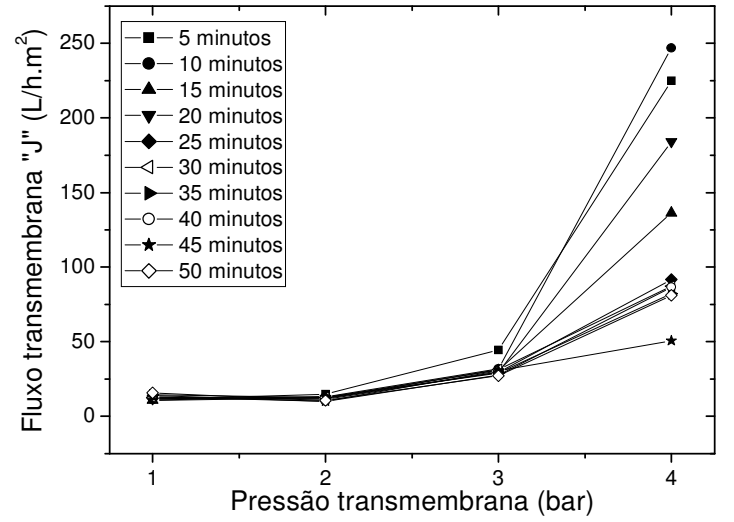

(a)

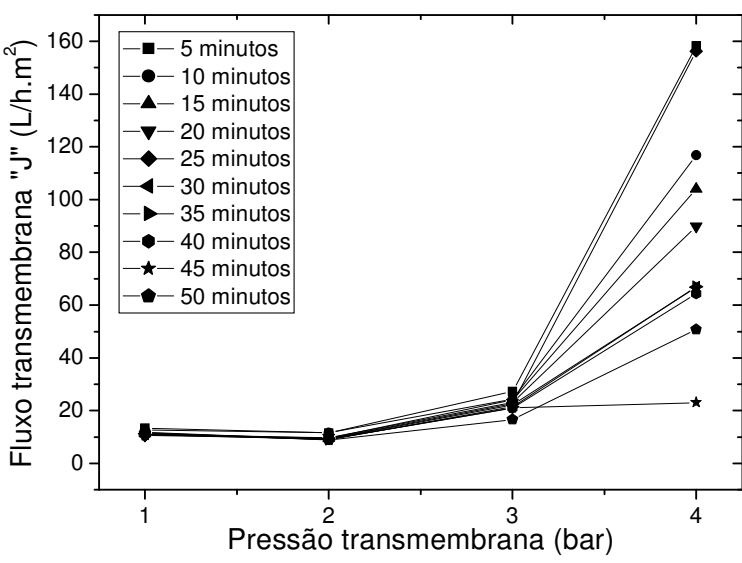

(c)

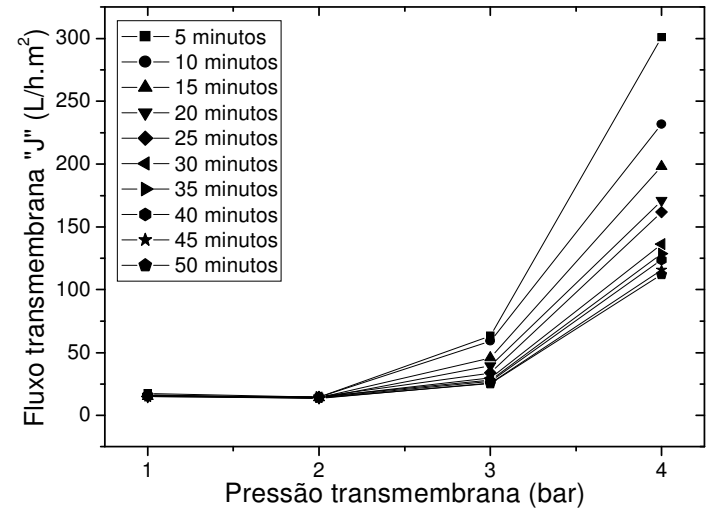

(b)

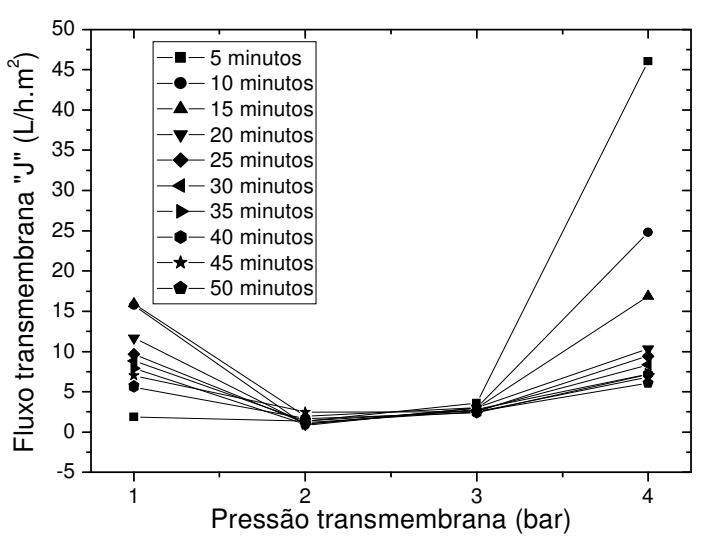

(d)

Figura 26- Gráfico da vazão transmembrana (L/h. $\left.\mathrm{m}^{2}\right)$ em função da variação da pressão para o processo de microfiltração tangencial com membrana comercial $(0,8 \mu \mathrm{m}$ de tamanho médio dos

poros; $190 \mathrm{~mm}$ de comprimento; 5,6 de diâmetro interno) sem impregnação de prata e escoamento turbulento $R e \approx 30000$ (a) e com prata $R e \approx 30000$ (b), $R e \approx 25000$ (c) e $R e \approx 20000$ (d).

Nas Figuras 26a, b e c, com pressão transmembrana à 4 bar, a vazão transmembrana foi maior do que no processo às demais pressões, porém ela não se manteve constante. Observa-se que do início (5 minutos) para o final (50 minutos) do processo, em todos os regimes de escoamento turbulento, há uma redução da vazão mássica, o que indica o fenômeno de formação da camada de polarização.

Da Figura 27 à Figura 29 são apresentados resultados decorrentes do uso de membrana comercial de origem alemã com tamanho nominal de poro igual a $1,2 \mu \mathrm{m}$. Esses experimentos foram realizados com água residuária da fabricação de queijo (soro), e realizados variando-se o número de Reynolds e 
coletando-se os permeados de um em um minuto.

$\mathrm{Na}$ Figura 27a, onde o regime de escoamento foi com $\mathrm{Re} \approx 4000$, observa-se que à 1 bar, o fluxo transmembrana variou de 7 à 13 L/(h.m²), enquanto à 2 bar, a variação ficou entre 9 a 11 L/(h.m $\left.{ }^{2}\right)$ e posteriormente à 3 bar, a vazão mássica manteve-se entre 7 e 19 L/(h.m²), o que significa dizer que há uma relação direta entre o comportamento do fluxo transmembrana e a pressão transmembrana ao longo do processo, no qual quanto maior a pressão, maior o fluxo do permeado.

$\mathrm{Na}$ Figura 27b, onde o regime de escoamento foi de $\mathrm{Re} \approx 3500$, a tendência do comportamento do fluxo transmembrana em relação a variação da pressão também foi de aumento, pois à 1 bar, o fluxo transmembrana manteve-se entre 4,5 e 6,5 L/(h.m $\left.{ }^{2}\right)$; à 2 bar, o fluxo transmembrana foi entre 5,5 e 8,5 L/(h.m $\left.{ }^{2}\right)$ e à 3 bar manteve-se entre 9,5 e $11 \mathrm{~L} /\left(\right.$ h. $\left.\mathrm{m}^{2}\right)$.

Na Figura 27c, onde o regime de escoamento foi com $\operatorname{Re} \approx 3000$ e 1 bar, o fluxo transmembrana manteve-se entre 5,25 e 6,25 L/(h.m²); à 2 bar, o fluxo transmembrana apresentou-se entre 6,0 e 7,25 L/(h. $\left.\mathrm{m}^{2}\right)$ e por fim, à 3 bar, manteve-se entre 7,0 e $10 \mathrm{~L} / \mathrm{h} \cdot \mathrm{m}^{2}$. Observa-se o aumento no fluxo transmembrana conforme se eleva a pressão transmembrana.

Nas Figuras 27a, b e c, desde o início (5 minutos) ao fim (50 minutos) do processo, nas três pressões transmembrana, observa-se a redução na vazão transmembrana.

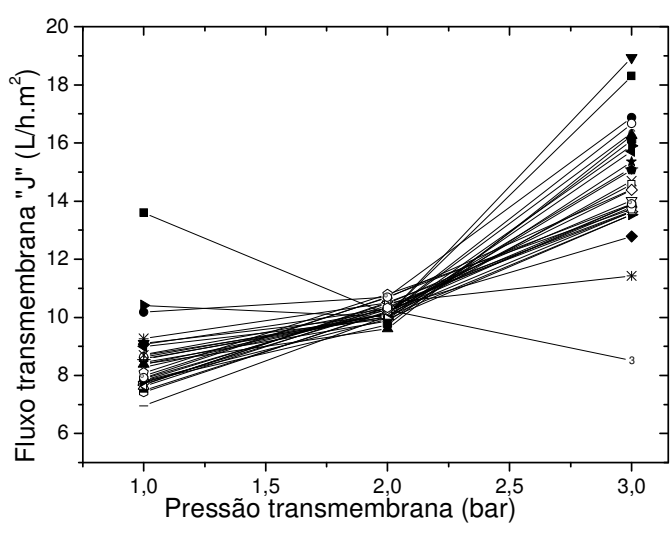

(a)

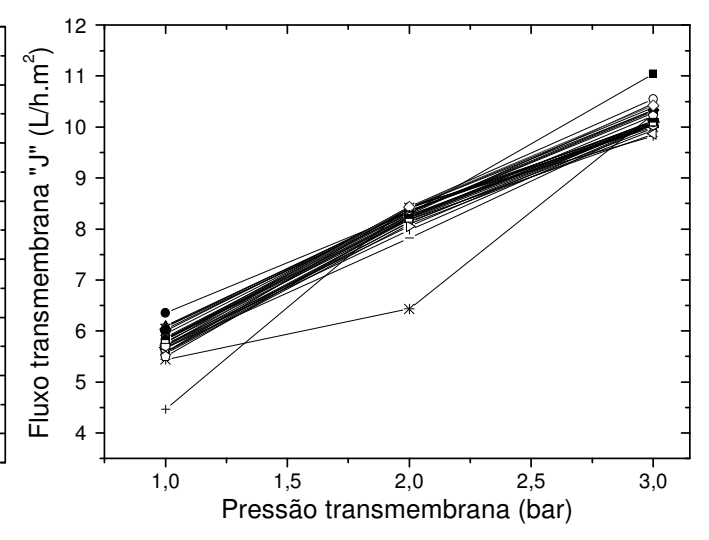

(b) 


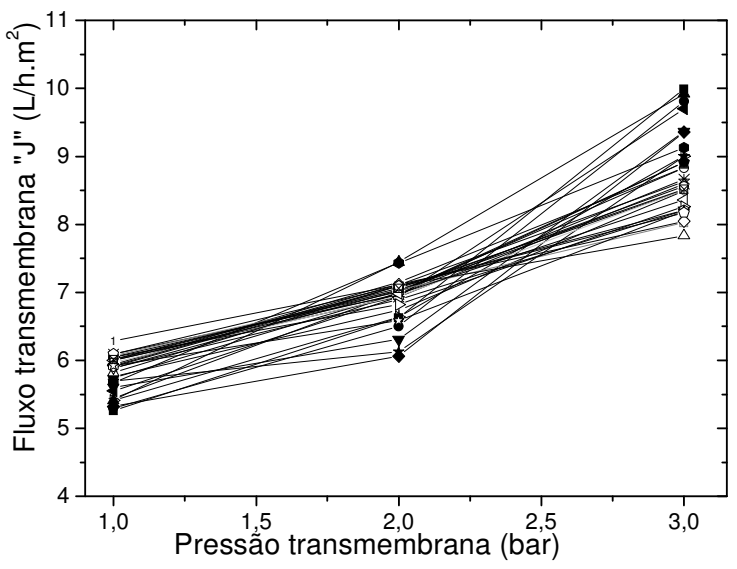

(c)

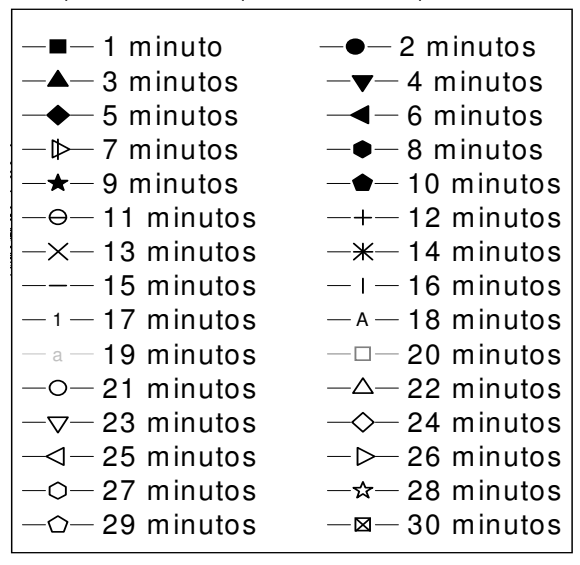

(d)

Figura 27- Gráfico da vazão transmembrana $\left(\mathrm{L} / \mathrm{h} \cdot \mathrm{m}^{2}\right)$ em função da variação da pressão para o processo de microfiltração tangencial com membrana comercial sem impregnação de prata, com $1,2 \mu \mathrm{m}$ de tamanho médio dos poros; $400 \mathrm{~mm}$ de comprimento; $6,0 \mathrm{~mm}$ de diâmetro interno em escoamento de transição de respectivamente $\operatorname{Re} \approx 4000$ (a), $\operatorname{Re} \approx 3500$ (b) e $\operatorname{Re} \approx 3000$ (c); legenda das figuras $27 \mathrm{a}, \mathrm{b}$ e c (d).

A Figura 28 apresenta resultados decorrentes do uso de membrana

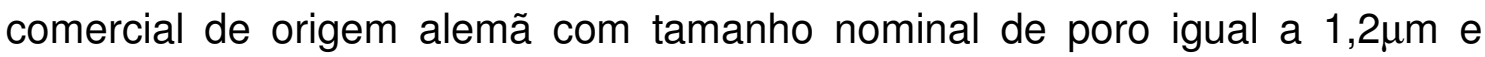
impregnada pela primeira vez com prata. Esses experimentos foram realizados com água residuária da fabricação de queijo (soro), e realizados variando-se o número de Reynolds e coletando-se os permeados de um em um minuto.

Na Figura 28a, o fluxo transmembrana manteve-se praticamente estável, se comparado nas três pressões transmembrana. Pode-se dizer que à 1 bar, do início (5 minutos) até o fim (50 minutos) do processo, a vazão mássica reduziu, assim como ocorreu à 2 e 3 bar.

Não se observa nas Figuras $28 \mathrm{~b}$ e c um aumento do fluxo transmembrana de 1 bar para 2 bar. Mas os valores de fluxo transmembrana correspondentes à 2 bar são menores do que à 3 bar.

Nas Figuras 28a, b e c, observa-se uma redução nos valores do fluxo transmembrana ao longo do processo (de 5 à 50 minutos), independentemente da variação da pressão, indicando o efeito da formação da camada de polarização. 


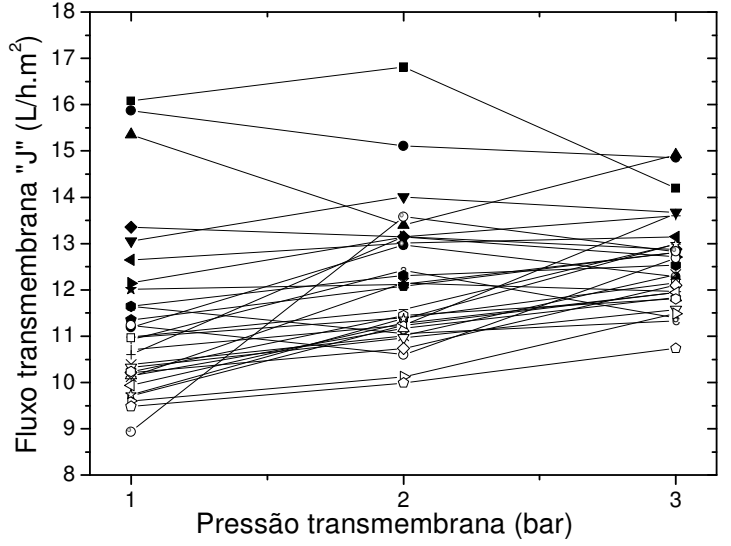

(a)

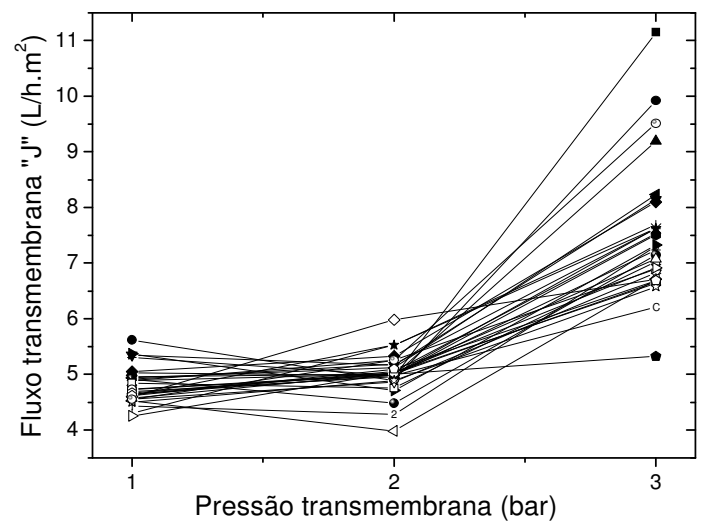

(c)

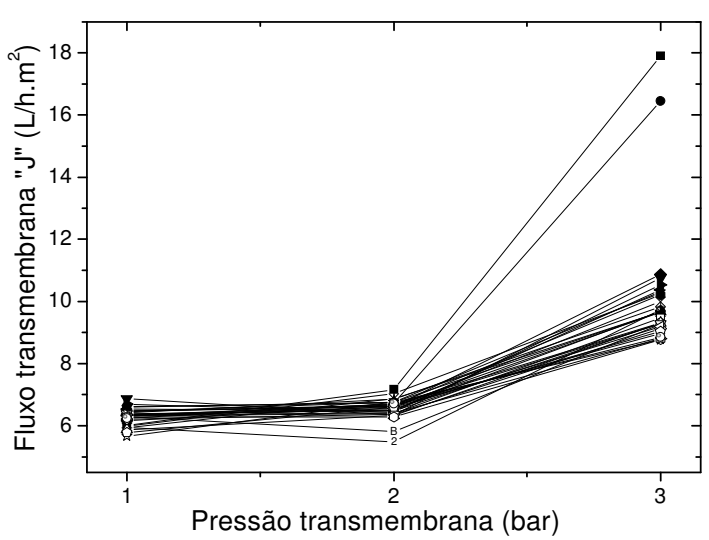

(b)

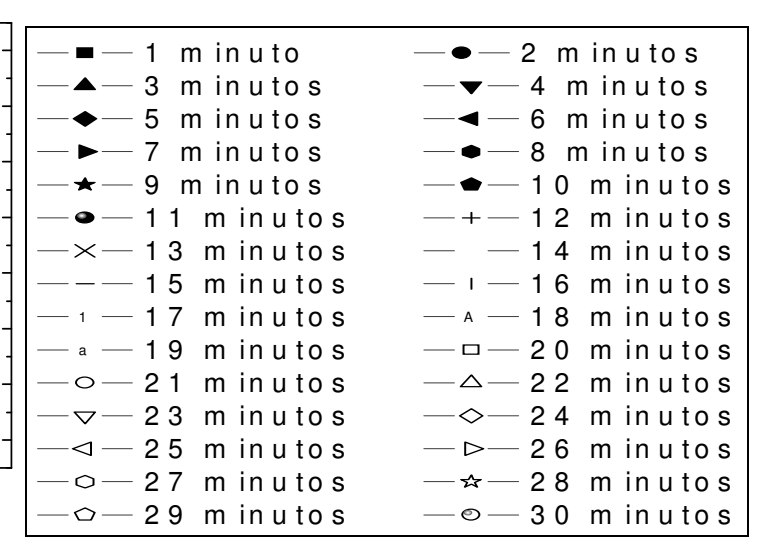

(d)

Figura 28- Gráfico da vazão transmembrana $\left(\mathrm{L} / \mathrm{h} \cdot \mathrm{m}^{2}\right)$ em função da variação da pressão para o processo de microfiltração tangencial com membrana comercial com a primeira impregnação de prata, com 1,2 $\mu \mathrm{m}$ de tamanho médio dos poros; $200 \mathrm{~mm}$ de comprimento; $6,0 \mathrm{~mm}$ de diâmetro interno em escoamento de transição de respectivamente $R e \approx 4000$ (a), $R e \approx 3500$ (b) e $\operatorname{Re} \approx 3000$ (c); legenda das figuras $28 \mathrm{a}$, b e c (d).

A Figura 29 apresenta resultados decorrentes do uso da membrana comercial de origem alemã com tamanho nominal de poro igual a $1,2 \mu \mathrm{m}$ e impregnada pela segunda vez com prata. Esses experimentos foram realizados com água residuária da fabricação de queijo (soro), e realizados variando-se o número de Reynolds e coletando-se os permeados de cinco em cinco minutos.

Nas Figuras 29a, b e c, o comportamento do fluxo transmembrana ao longo do processo foi semelhante, indicando-se uma redução do fluxo do início (5 minutos) para o fim (50 minutos) do experimento às pressões de 1, 2 e 4 bar. A 3 bar, o fluxo transmembrana manteve-se praticamente constante em todos os regimes de escoamento. Esse comportamento se deve ao fato de 3 bar ter sido a última pressão estabelecida no processo e conseqüentemente, tendo-se 
a camada de polarização já estabilizada.

Nas Figuras 29b e c, observa-se que de 1 para 2 bar e de 3 para 4 bar, o fluxo transmembrana aumentou, enquanto de 2 para $3 \mathrm{bar}$, em geral o fluxo transmembrana reduziu.

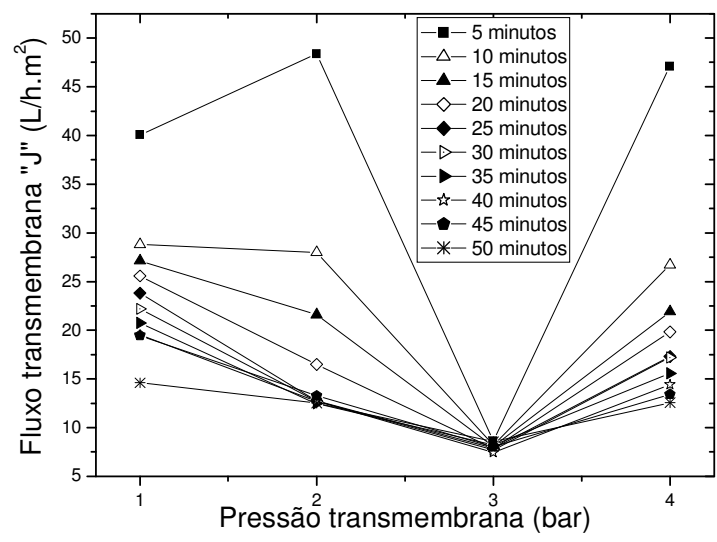

(a)

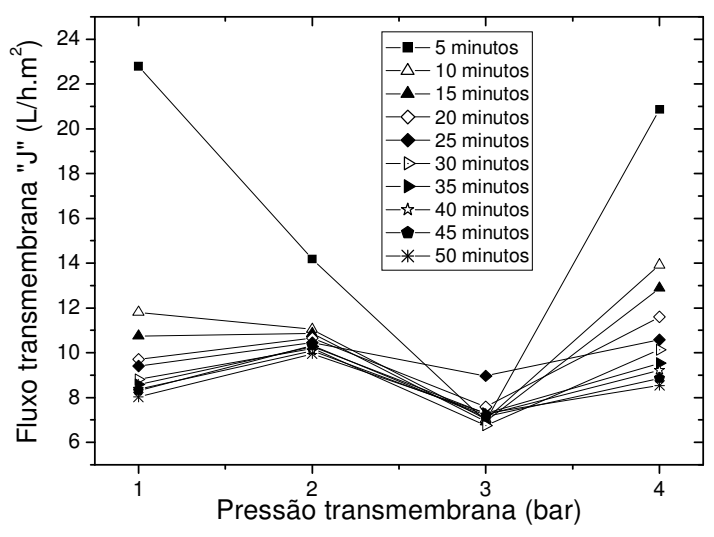

(b)

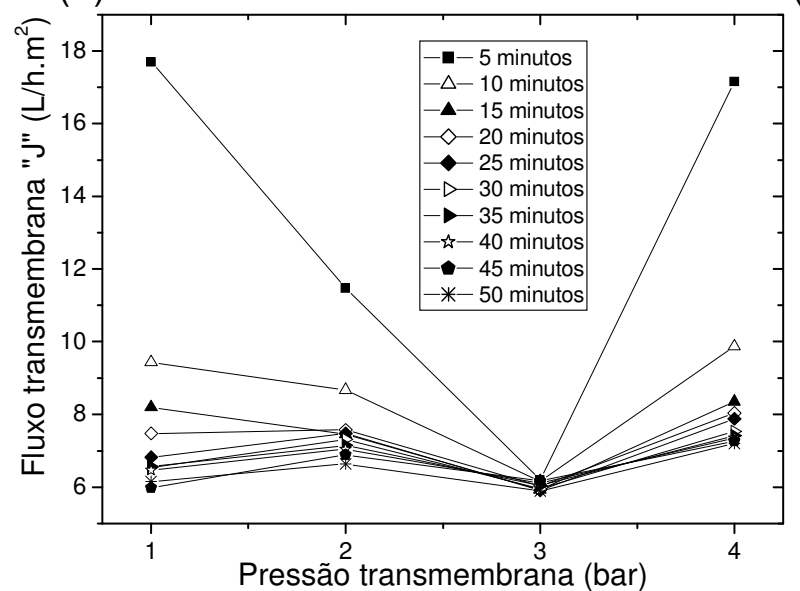

(c)

Figura 29- Gráfico da vazão transmembrana $\left(L / h \cdot \mathrm{m}^{2}\right)$ em função da variação da pressão para o processo de microfiltração tangencial com membrana comercial com a segunda impregnação de prata, com 1,2 $2 \mu \mathrm{m}$ de tamanho médio dos poros; $200 \mathrm{~mm}$ de comprimento; $6,0 \mathrm{~mm}$ de diâmetro interno em escoamento turbulento de respectivamente $\operatorname{Re} \approx 4000$ (a), $\operatorname{Re} \approx 3500$ (b) e $\operatorname{Re} \approx 3000$ (c).

A Figura 30 apresenta resultados decorrentes do uso de tubo cerâmico de alumina com tamanho nominal de poro igual a $0,4 \mu \mathrm{m}$, fabricado pela técnica de extrusão e sem a impregnação de prata. Esses experimentos foram realizados com água residuária da fabricação de queijo (soro), e realizados variando-se o número de Reynolds e coletando-se os permeados de cinco em cinco minutos. 
$\mathrm{Na}$ Figura 30a, onde o regime de escoamento era de $\mathrm{Re} \approx 25000$, observa-se que de 1 para 2 bar e de 3 para 4 bar, o fluxo transmembrana aumentou, enquanto de 2 para 3 bar, o comportamento do fluxo foi de redução. À 1 bar e a 3 bar observa-se que o fluxo transmembrana permanece constante, enquanto à 2 e à 4 bar, a vazão mássica diminui ao longo do processo (de 5 à 50 minutos).

Nas Figuras 30b e c, de 1 para 2 bar, o fluxo transmembrana reduziu, enquanto de 2 para 3 bar e de 3 para 4 bar, o comportamento do fluxo aumentou. À 1 bar e à 4 bar observa-se que o fluxo transmembrana reduziu, enquanto à 2 e à 3 bar, a vazão mássica permaneceu praticamente constante ao longo do processo (de 5 à 50 minutos).

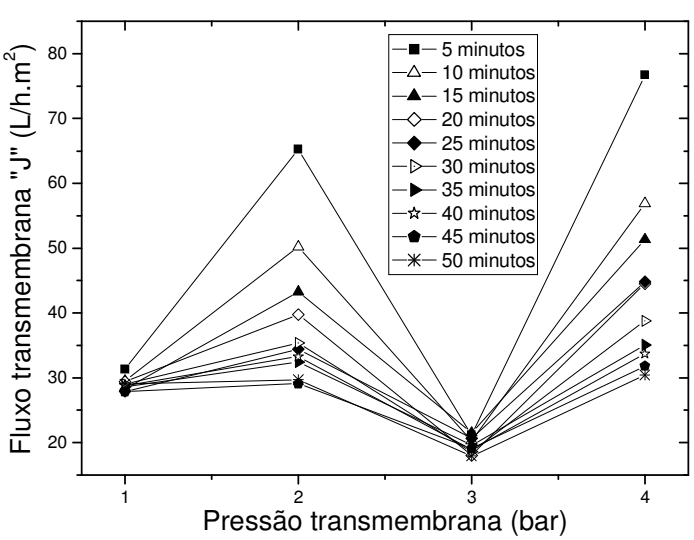

(a)

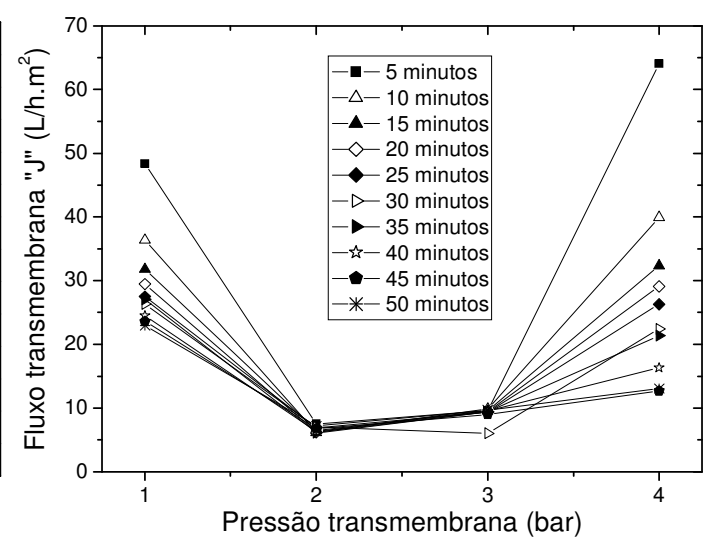

(b)

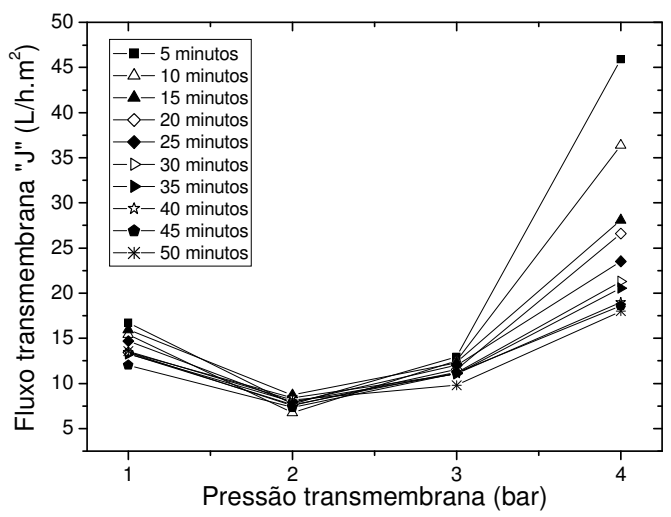

(c)

Figura 30- Gráfico da vazão transmembrana (L/h. $\left.\mathrm{m}^{2}\right)$ em função da variação da pressão para o processo de microfiltração tangencial com tubo cerâmico sem impregnação de prata, com $0,4 \mu \mathrm{m}$ de tamanho médio dos poros; $170 \mathrm{~mm}$ de comprimento; 7,0mm de diâmetro interno em escoamento turbulento de respectivamente $R e \approx 25000$ (a), $R e \approx 20000$ (b) e $R e \approx 17000$ (c). 
A Figura 31 apresenta resultados decorrentes do uso de tubo cerâmico de alumina com tamanho nominal de poro igual a 0,5 $\mu \mathrm{m}$, fabricado através da técnica de colagem e sem a impregnação de prata. Esses experimentos foram realizados com água residuária da fabricação de queijo (soro), e realizados variando-se o número de Reynolds e coletando-se os permeados de cinco em cinco minutos.

$\mathrm{Na}$ Figura 31a, onde o regime de escoamento turbulento corresponde a $\mathrm{Re} \approx 21000$, de 1 para 2 bar e de 3 para 4 bar, o comportamento do fluxo transmembrana é de aumento, enquanto de 2 para 3 bar, o comportamento dos valores do fluxo é de redução. Em relação ao tempo de coleta (de 5 a 50 minutos), observa-se que os valores do fluxo transmembrana diminuem à 1,2 e 4 bar, enquanto à 3 bar, a vazão mássica permanece constante.

Na Figura 31 b, onde o regime de escoamento turbulento corresponde a $R e \approx 18000$, de 1 para 2 bar, observa-se uma redução nos valores do fluxo transmembrana, enquanto de 2 para 3 bar e de 3 para 4 bar, nota-se um aumento nos valores da vazão mássica transmembrana. À 1 e 4 bar, observase redução nos valores do fluxo transmembrana, enquanto à 2 e 3 bar, a vazão mássica permanece constante ao longo do processo (de 5 à 50 minutos).

Nas Figura $31 \mathrm{c}$, onde o regime de escoamento turbulento corresponde a $R e \approx 15000$, de 1 para 2 bar, observa-se uma redução nos valores do fluxo transmembrana, enquanto de 2 para 3 bar permanecem praticamente estáveis. Há um aumento no comportamento do fluxo transmembrana de 3 para 4 bar. Em todas as pressões, observa-se que o fluxo transmembrana reduziu ao longo do processo (de 5 à 50 minutos). 


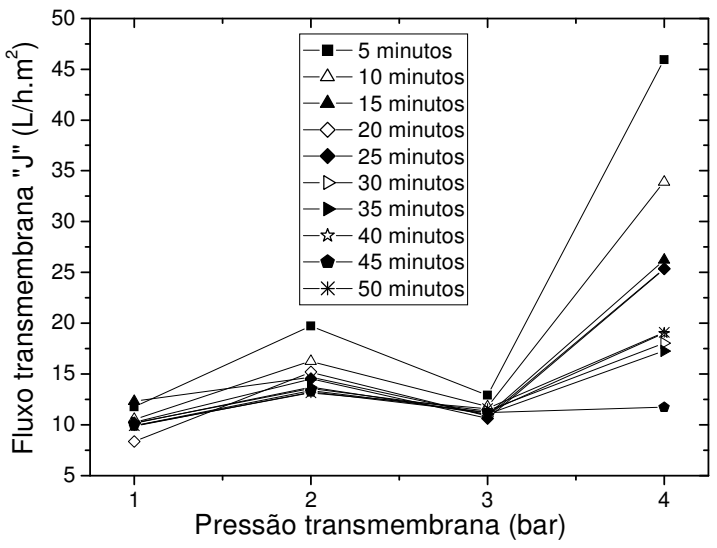

(a)

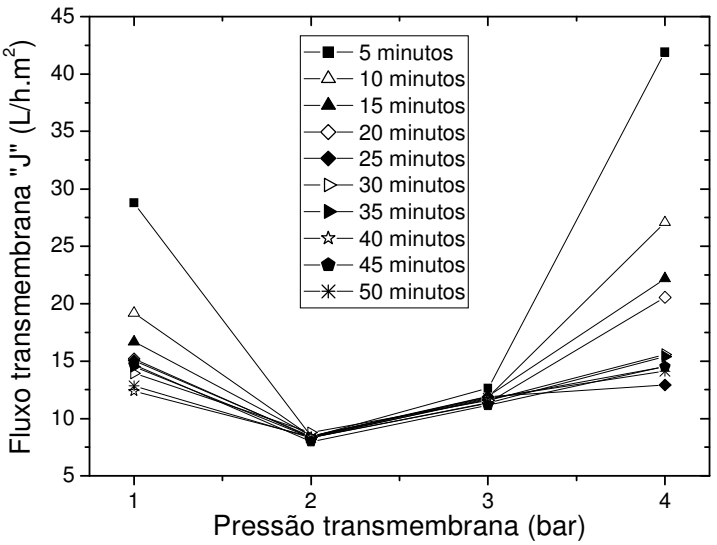

(b)

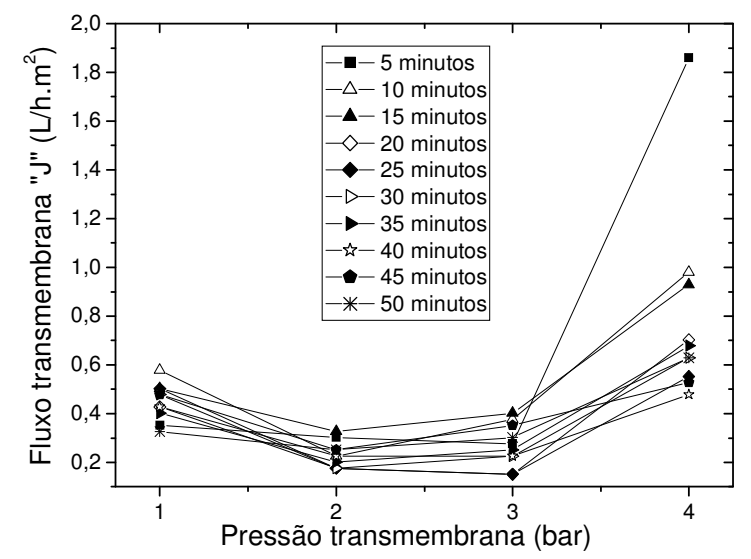

(c)

Figura 31- Gráfico da vazão transmembrana $\left(\mathrm{L} / \mathrm{h} \cdot \mathrm{m}^{2}\right)$ em função da variação da pressão para o processo de microfiltração tangencial com tubo cerâmico, sem impregnação de prata, com $0,5 \mu \mathrm{m}$ de tamanho médio dos poros; $190 \mathrm{~mm}$ de comprimento; $8,0 \mathrm{~mm}$ de diâmetro interno em escoamento turbulento de respectivamente $\operatorname{Re} \approx 21000$ (a), $\operatorname{Re} \approx 18000$ (b) e $\operatorname{Re} \approx 15000$ (c).

Os valores do fluxo transmembrana sofreram redução de 100 vezes com o processo conduzido ao menor valor de Reynolds, Re $\approx 15000$ (Figura 31c). Neste caso, o cisalhamento da corrente de mistura não foi suficiente para elevar a vazão transmembrana.

Deve-se ressaltar que entre cada série de experimentos foi realizado sistematicamente o procedimento de limpeza citado na metodologia (Capítulo $3)$.

A recuperação do fluxo transmembrana foi em geral atendido, porém neste trabalho não foi possível o controle da composição e concentração da suspensão (soro) residual, podendo haver variações entre as amostras processadas. 


\subsection{VAZÃo tRANSMEMbrana (L/H.M²) EM FUnÇÃo do NÚmERO DE REYNOLDS "RE"}

As figuras apresentadas nessa seção, representam o comportamento final da vazão mássica transmembrana $\left(L / h \cdot m^{2}\right)$, em função do número de Reynolds. Este comportamento final significa o último valor de permeado coletado no processo de microfiltração, utilizando-se as diferentes estruturas microporosas. Com exceção do último valor de permeado coletado, aos 30 minutos de processo na membrana comercial de 1,2 $\mu \mathrm{m}$, nas demais estruturas microporosas, o último permeado foi coletado aos 50 minutos.

A Figura 32 apresenta os resultados da vazão transmembrana em função do número de Reynolds para o final (50 minutos) do processo. Os resultados são decorrentes do processo de microfiltração tangencial com membrana comercial de origem alemã, com tamanho nominal de poro igual a $0,8 \mu \mathrm{m}$ e com impregnação de prata.

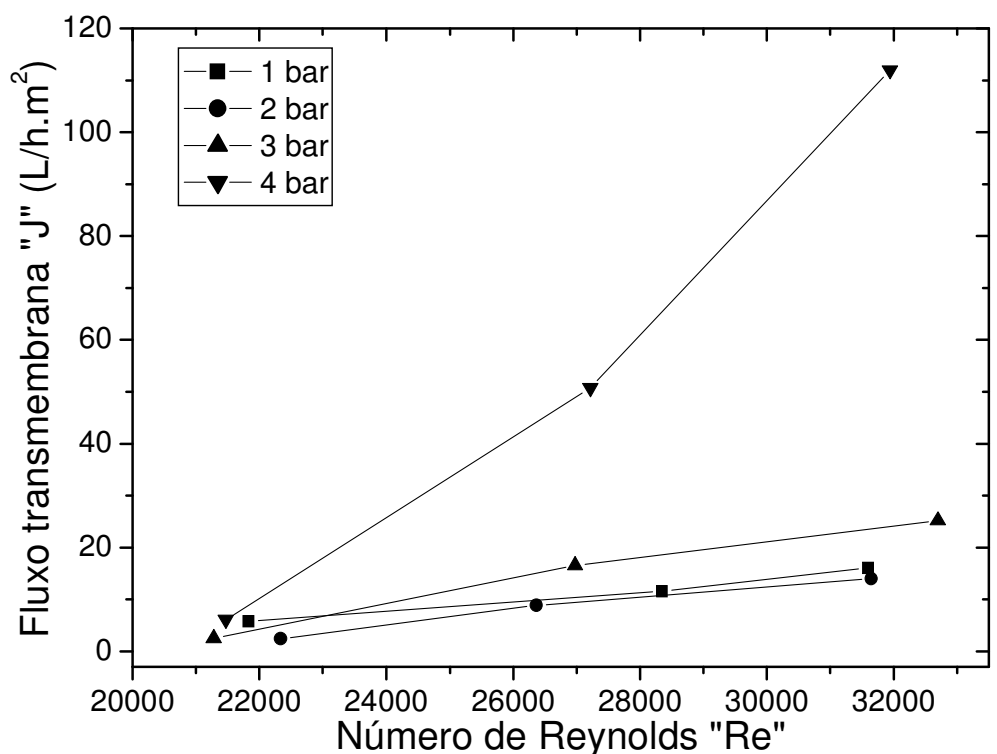

Figura 32- Gráfico da vazão transmembrana (L/h. $\left.\mathrm{m}^{2}\right)$ no final do processo (50 minutos) em função do número de Reynolds para o processo de microfiltração tangencial com membrana comercial, com impregnação de prata, com $0,8 \mu \mathrm{m}$ de tamanho médio dos poros; $190 \mathrm{~mm}$ de comprimento; 5,6 de diâmetro interno em escoamento turbulento.

A Figura 33 apresenta os resultados da vazão transmembrana em função do número de Reynolds para o final (30 minutos) do processo. Os resultados são decorrentes do processo de microfiltração tangencial com membrana comercial de origem alemã e com tamanho nominal de poro igual a 
$1,2 \mu \mathrm{m}$. Observa-se na Figura 33 resultados para o processo utilizando a membrana sem impregnação de prata e outros mostrando o desempenho da membrana com impregnação de prata.

Observa-se na Figura 32 e na Figura 33 que o comportamento da vazão transmembrana ao longo do processo aumentou de acordo com o aumento da pressão e do número de Reynolds. Nota-se esse comportamento para o processo em todas as pressões transmembrana (1,2,3 e 4 bar).

Na Figura 33 não se observa nenhuma diferença de comportamento devido a segunda impregnação da prata na estrutura cerâmica, ou seja, o comportamento da vazão transmembrana permaneceu estável e com pouca variação quantitativa ao longo do processo.

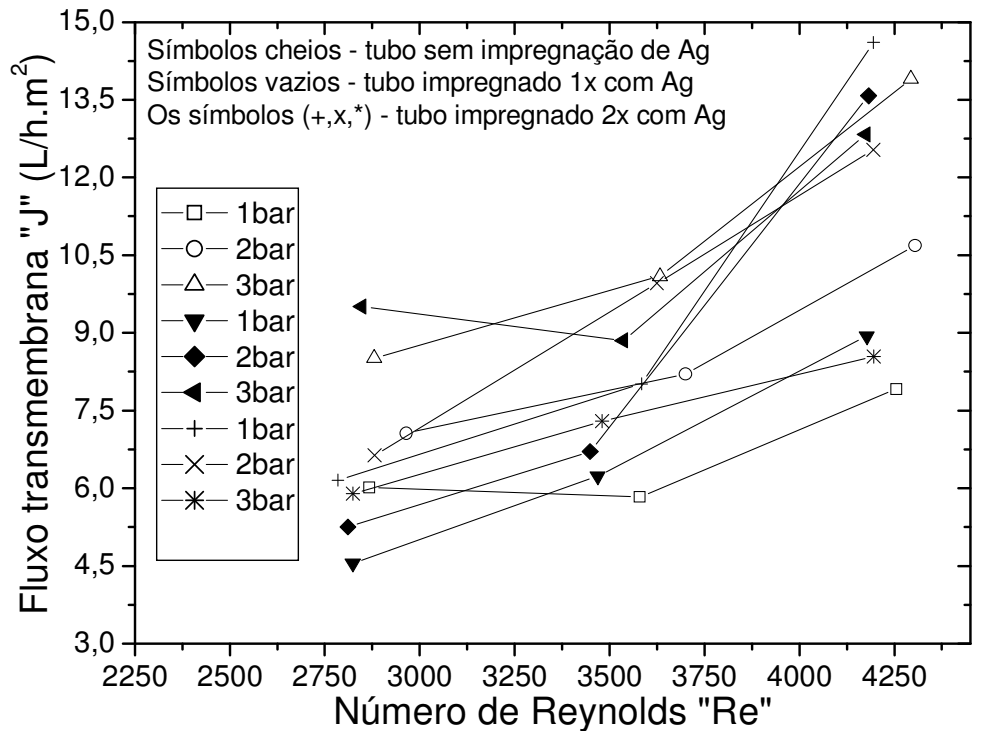

Figura 33 - Gráfico da vazão transmembrana $\left(\mathrm{L} / \mathrm{h} \cdot \mathrm{m}^{2}\right)$ do final do processo (30minutos) em função do número de Reynolds para o processo de microfiltração tangencial com membrana comercial, sem impregnação, com uma e duas impreganações, com 1,2 $\mu \mathrm{m}$ de tamanho médio dos poros; $400 \mathrm{~mm}$ de comprimento; $6,0 \mathrm{~mm}$ de diâmetro interno em escoamento turbulento, à

$$
1,2 \text { e } 3 \text { bar. }
$$

A Figura 34 apresenta os resultados da vazão transmembrana em função do número de Reynolds para o final (50 minutos) do processo. Os resultados são decorrentes do processo de microfiltração tangencial com tubo cerâmico de alumina fabricado pela técnica de extrusão, com tamanho nominal de poro igual a 0,4 $\mu \mathrm{m}$ e sem impregnação de prata. 


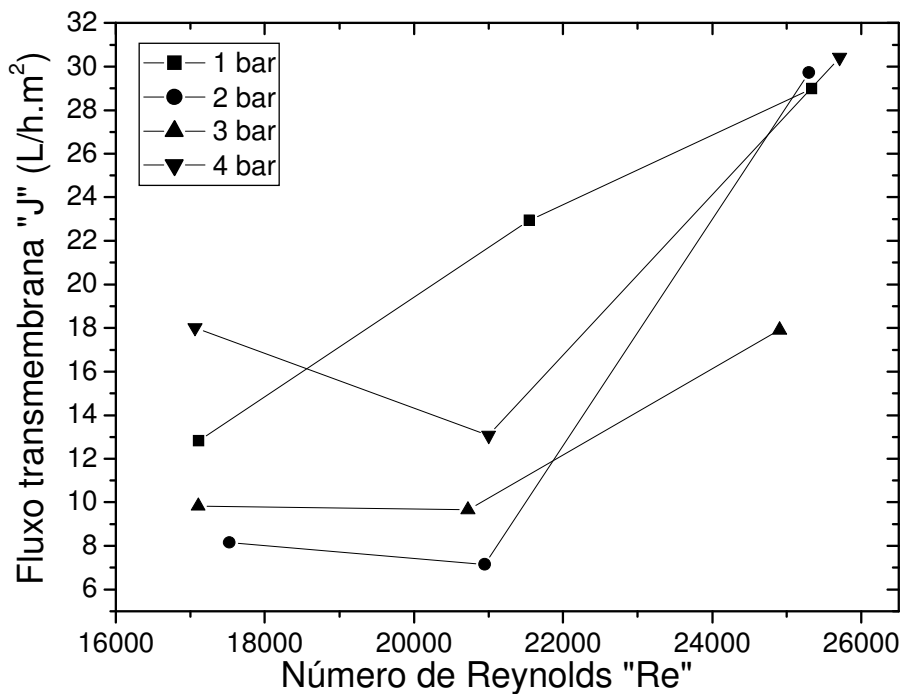

Figura 34- Gráfico da vazão transmembrana (L/h. $\left.\mathrm{m}^{2}\right)$ no final do processo (50 minutos) em função do número de Reynolds para o processo de microfiltração tangencial com tubo cerâmico sem impregnação de prata, com $0,4 \mu \mathrm{m}$ de tamanho médio dos poros; $170 \mathrm{~mm}$ de comprimento;

7,0mm de diâmetro interno em escoamento turbulento e à 1,2, 3 e 4 bar.

A Figura 35 apresenta os resultados da vazão transmembrana em função do número de Reynolds para o final (50 minutos) do processo. Os resultados são decorrentes do processo de microfiltração tangencial com tubo cerâmico de alumina fabricado pela técnica da colagem, com tamanho nominal de poro igual a $0,5 \mu \mathrm{m}$ e sem impregnação de prata.

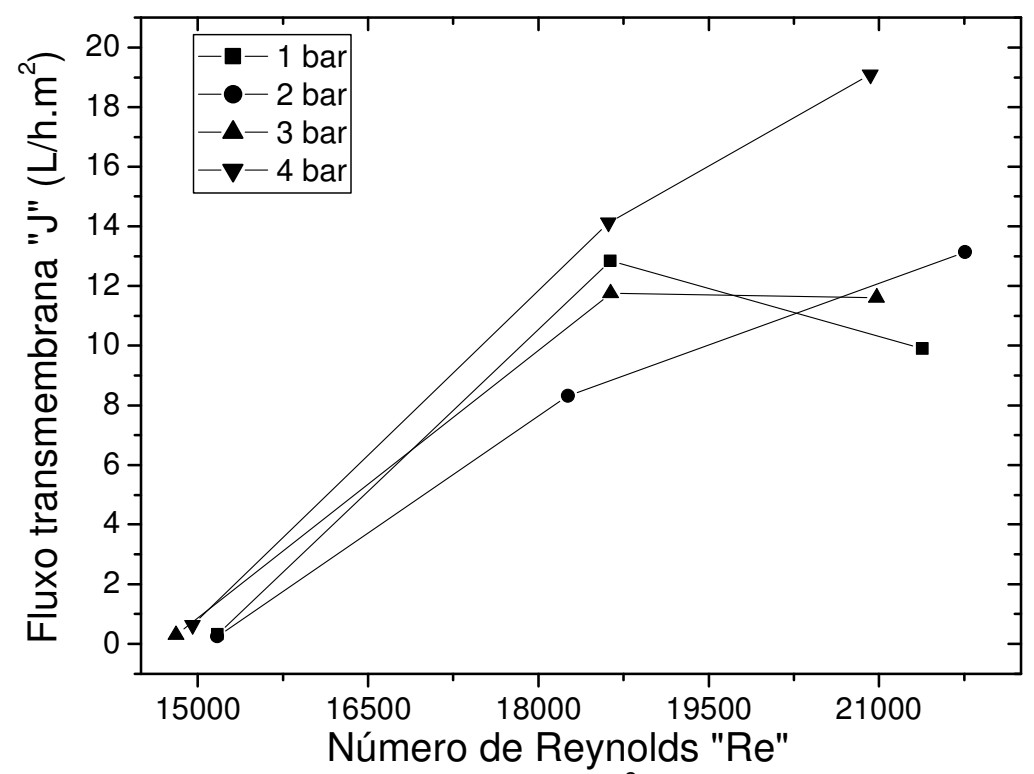

Figura 35 - Gráfico da vazão transmembrana (L/h. $\left.\mathrm{m}^{2}\right)$ no final do processo (50 minutos) em função do número de Reynolds para o processo de microfiltração tangencial com tubo cerâmico sem impregnação de prata, com $0,5 \mu \mathrm{m}$ de tamanho médio dos poros; $190 \mathrm{~mm}$ de comprimento;

$8,0 \mathrm{~mm}$ de diâmetro interno em escoamento turbulento e à 1,2, 3 e 4 bar. 
Nota-se que os valores do fluxo transmembrana apresentados nas Figura 34 e na Figura 35, são maiores do que os de "J" da Figura 33, sendo interessante observar que esses maiores valores de "J" correspondem às vazões transmembrana obtidas respectivamente nos processos de microfiltração tangencial com o tubo cerâmico de valor nominal de poro igual a $0,4 \mu \mathrm{m}$ e tubo cerâmico de valor nominal de poro igual a $0,5 \mu \mathrm{m}$, comparados à

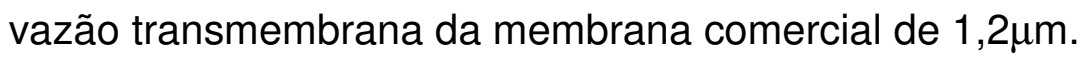

Analisando-se o comportamento do "J" em função de "Re" na Figura 32 à Figura 35, nota-se que prevalece uma tendência de aumento de "J" com o aumento de "Re". Esse comportamento é característico e citado na literatura (HENRY \& ALLRED, 1972 apud SCOTT, 1995) de modo geral, buscando-se correlações na forma:

$\mathrm{J}=\mathrm{k} \cdot \mathrm{Re}^{\mathrm{n}}$, onde k e n são constantes, "J" é a vazão transmembrana e "Re" é o número adimensional de Reynolds.

\subsection{ANÁlise do modelo de RESistênCIA para o PROCESSO COM ESTRUTURAS MICROPOROSAS}

As figuras apresentadas nessa seção representam o comportamento da resistência à formação da camada de polarização $\left(R_{C}\right)$ em função do número de Reynolds $(\mathrm{Re})$ ao longo do processo de microfiltração tangencial nas estruturas microporosas.

Os valores resultantes dos cálculos das resistências apresentadas da Figura 36 à Figura 41 são registrados no Anexo B.

A Figura 36 apresenta o comportamento da resistência total à formação da camada de polarização $\left(R_{C}\right)$. As resistências foram calculadas para a membrana comercial de tamanho nominal de poro igual a 0,8 $\mu \mathrm{m}$, com a impregnação da prata, com variação para a pressão transmembrana e o número de Reynolds, especificados na figura.

Na Figura 36 observa-se a diminuição do valor da resistência total à formação da camada de polarização conforme o aumento do número de 
Reynolds, ou seja, quanto maior o número de Reynolds, menor será o valor de $\mathrm{R}_{\mathrm{C}}$.

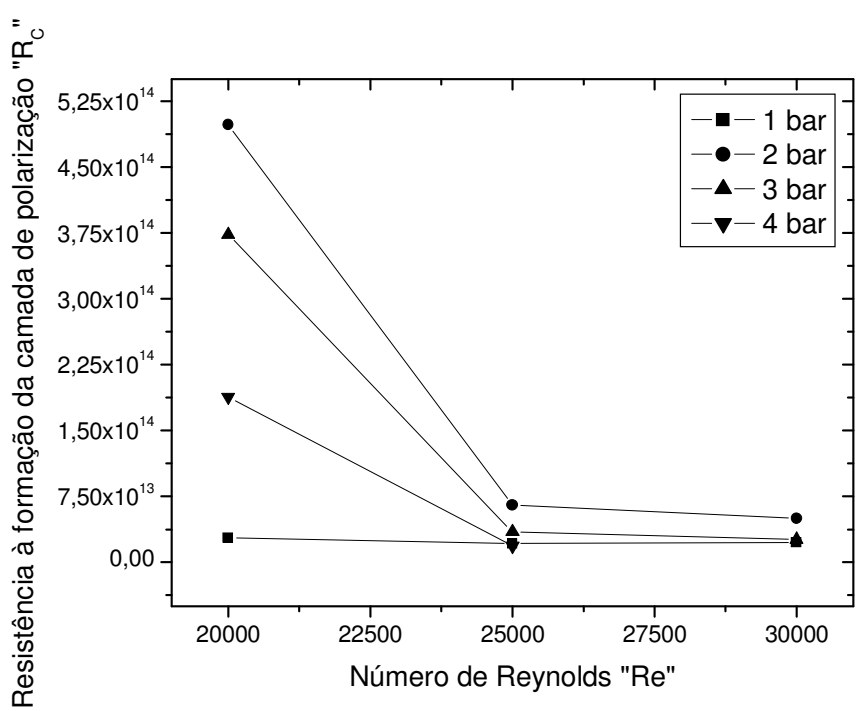

Figura 36 - Resistência à formação da camada de polarização " $\mathrm{R}_{\mathrm{C}}$ " da membrana comercial de tamanho nominal de poro igual a $0,8 \mu \mathrm{m}$ para os regimes de escoamentos turbulentos.

A Figura 37 apresenta os valores da resistência total à formação da camada de polarização $\left(R_{C}\right)$ calculados para a membrana comercial de tamanho nominal de poro igual a 1,2 $\mu \mathrm{m}$, sem impregnação da prata, com variação para a pressão transmembrana e o número de Reynolds, especificados na figura.

Na Figura 37 observa-se a diminuição da $R_{C}$ conforme o aumento do número de Reynolds, enquanto um comportamento inverso ocorre entre a $R_{C} e$ a pressão transmembrana. 


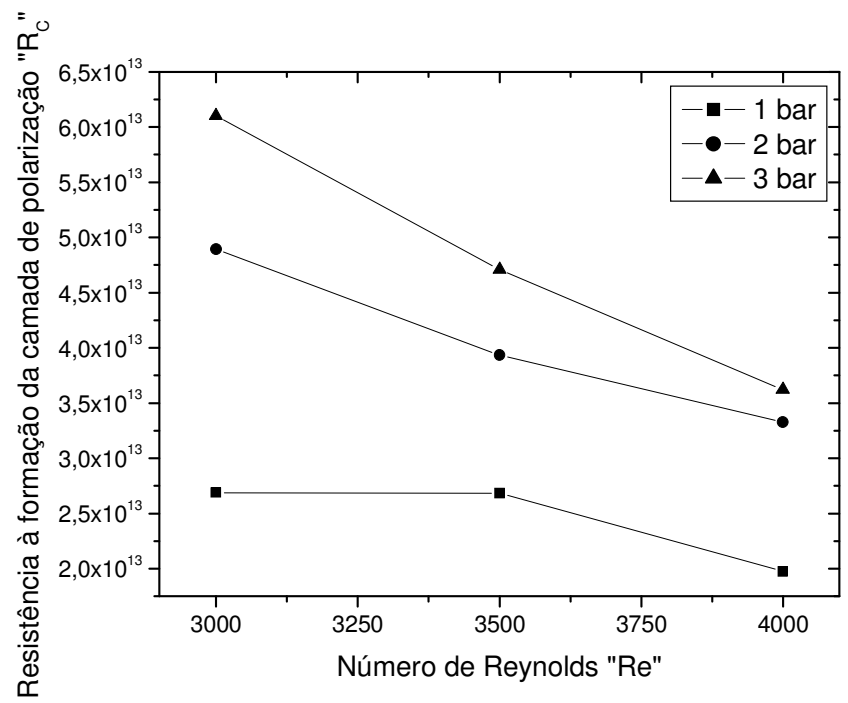

Figura 37- Resistência à formação da camada de polarização " $\mathrm{R}_{\mathrm{C}}$ " da membrana comercial de tamanho nominal de poro igual $1,2 \mu \mathrm{m}$, sem impregnação de prata, para os regimes de escoamento de transição.

A Figura 38 apresenta o comportamento da resistência total à formação da camada de polarização $\left(R_{C}\right)$ da membrana comercial de tamanho nominal de poro igual a 1,2 $\mu \mathrm{m}$, com a primeira impregnação da prata, com variação para a pressão transmembrana e o número de Reynolds, especificados na figura.

Na Figura 38 observa-se a diminuição da $R_{C}$ conforme o aumento do número de Reynolds e diminuição da pressão transmembrana, ou seja, nas menores pressões, a resistência à formação da camada de polarização é menor. 


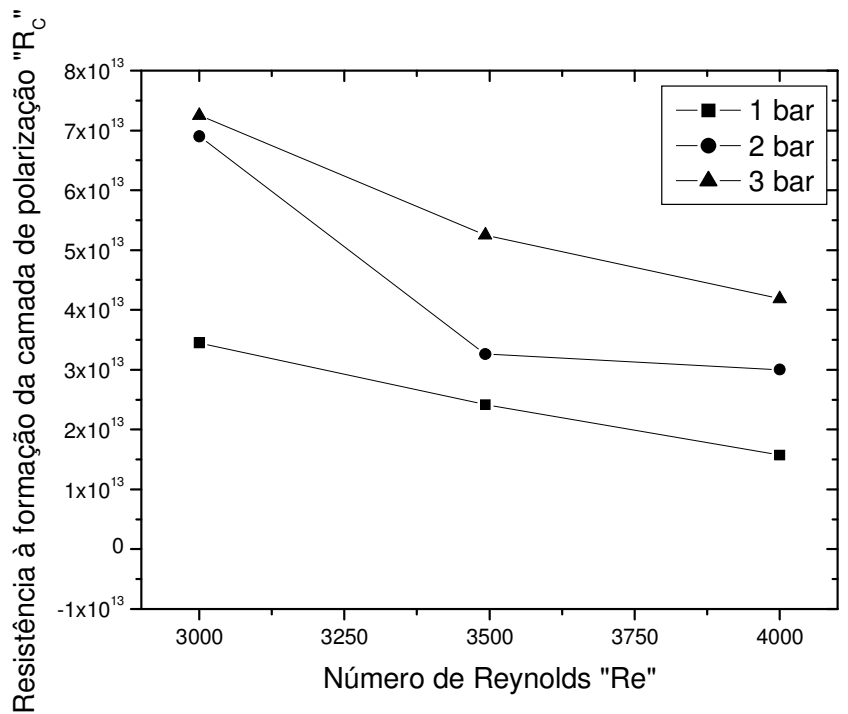

Figura 38- Resistência à formação da camada de polarização " $R_{C}$ " da membrana comercial de tamanho nominal de poro igual $1,2 \mu \mathrm{m}$, com a primeira impregnação de prata, para os regimes de escoamentos de transição.

A Figura 39 apresenta o comportamento da resistência total à formação da camada de polarização $\left(R_{C}\right)$ da membrana comercial de tamanho nominal de poro igual a 1,2 $\mu \mathrm{m}$, com a segunda impregnação da prata, com variação para a pressão transmembrana e o número de Reynolds, especificados na figura.

Na Figura 39 observa-se a diminuição da $R_{C}$ conforme o aumento do número de Reynolds e diminuição da pressão transmembrana, ou seja, nas menores pressões, a resistência à formação da camada de polarização é menor. 


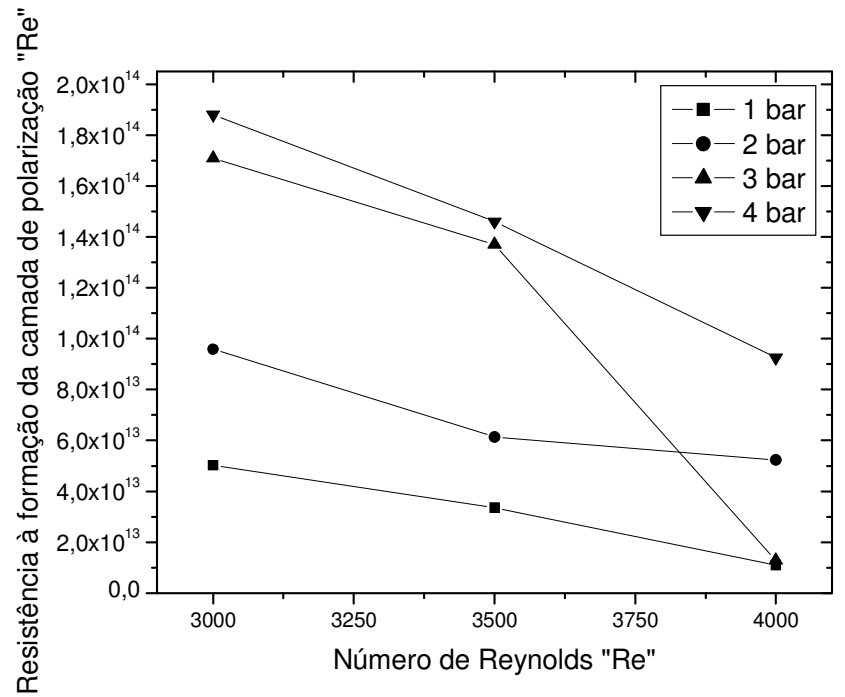

Figura 39 - Resistência à formação da camada de polarização " $\mathrm{R}_{\mathrm{C}}$ " da membrana comercial de tamanho nominal de poro igual $1,2 \mu \mathrm{m}$, com a segunda impregnação de prata, para os regimes de escoamentos de transição.

Comparando-se o comportamento da " $R_{C}$ " em função de "Re" apresentado nas Figuras 37, 38 e 39, observa-se que a membrana comercial de 1,2 $\mu \mathrm{m}$ duas vezes impregnada com prata (Figura 39) apresentou valores de resistência maiores do que a membrana comercial sem impregnação (Figura 37) e com uma impregnação (Figura 38).

A Figura 40 apresenta o comportamento da resistência total à formação da camada de polarização $\left(R_{C}\right)$ no tubo cerâmico de tamanho nominal de poro igual a 0,4 $\mu \mathrm{m}$, sem impregnação da prata, com variação para a pressão transmembrana e o número de Reynolds, especificados na figura.

Na Figura 40 observa-se a diminuição da $R_{C}$ conforme o aumento do número de Reynolds e com a variação da pressão transmembrana. Os maiores valores de $\mathrm{R}_{\mathrm{C}}$ à 3 bar indicam a tendência de aumento da resistência à formação da camada de polarização ao longo do processo. A seqüência da pressão transmembrana testada é diretamente proporcional à resistência à formação da camada de polarização. 


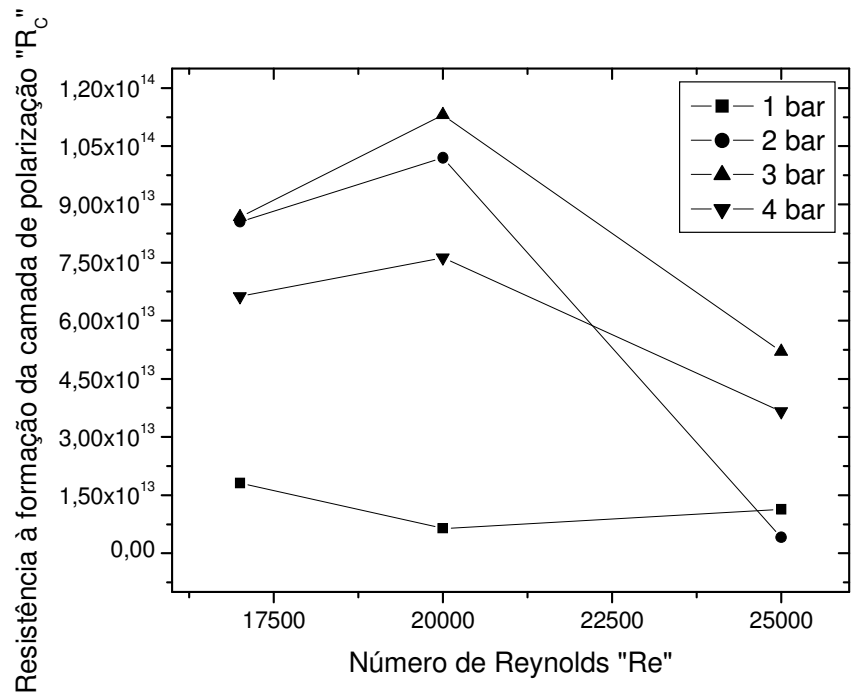

Figura 40 - Resistência à formação da camada de polarização " $R_{C}$ " do tubo cerâmico $0,4 \mu m$ para os regimes de escoamentos turbulentos.

A Figura 41 apresenta o comportamento da resistência total à formação da camada de polarização $\left(R_{C}\right)$ no tubo cerâmico de tamanho nominal de poro igual a 0,5 $\mu \mathrm{m}$, sem impregnação da prata, com variação para a pressão transmembrana e o número de Reynolds, especificados na figura.

Na Figura 41 observa-se a redução da $R_{C}$ conforme o aumento do número de Reynolds e variação da $R_{c}$ conforme a variação da pressão transmembrana. Os maiores valores de resistência à formação da camada de polarização $\left(\mathrm{R}_{\mathrm{C}}\right)$ foram registrados neste caso.

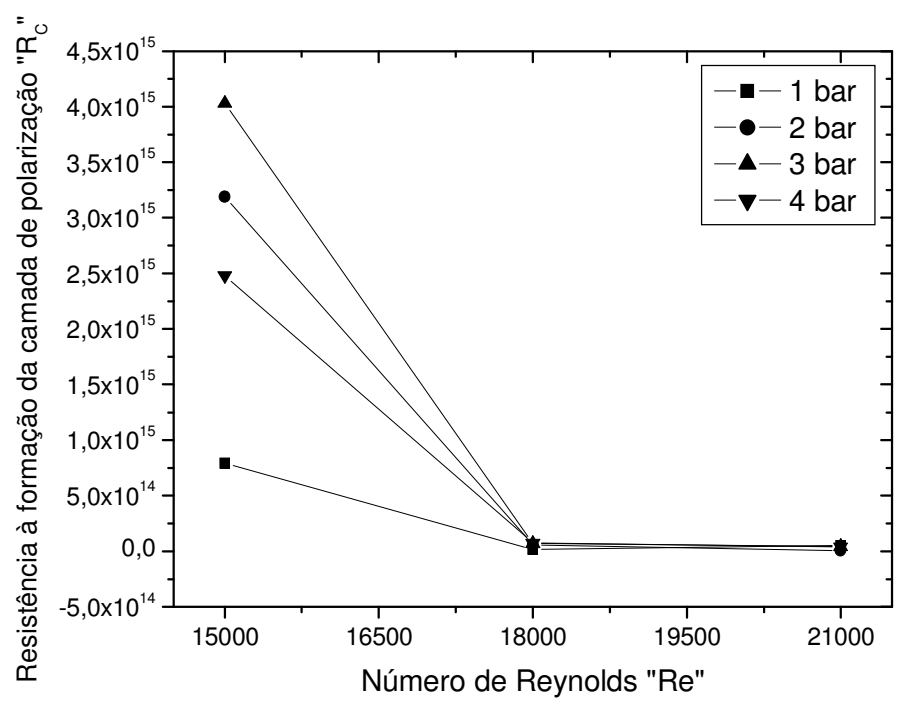

Figura 41 - Resistência à formação da camada de polarização " $R_{C}$ " do tubo cerâmico $0,5 \mu \mathrm{m}$ para os regimes de escoamentos turbulentos. 
Observa-se da Figura 36 à Figura 41 uma tendência semelhante de variação entre a resistência total à formação da camada de polarização $\left(R_{C}\right)$ e o número de Reynolds, mesmo com estruturas microporosas fabricadas com técnicas diferentes, porém com semelhança morfológica como citada no item 4.1 .

\subsection{ANÁlise MiCROBiológica dos PERMEAdOS NOS PROCESSOS DE MICROFILTRAÇÃO}

Os resultados apresentados nessa seção correspondem à análise microbiológica dos permeados coletados durante o processo de microfiltração tangencial na experimentação das diferentes estruturas cerâmicas com e sem a impregnação da prata. O objetivo dessa análise foi avaliar a possível influência da impregnação de prata nos tubos microporosos, bem como do processamento em diferentes pressões transmembrana e número de Reynolds.

A Tabela 2 apresenta a amostragem do número de unidades formadoras de colônias (UFC) das bactérias do grupo coliforme (E. coli) por grama de permeado coletado aos 15 minutos de processo, em diferentes pressões transmembrana e número de Reynolds para a membrana comercial de tamanho nominal de poro igual a $0,8 \mu \mathrm{m}$.

$\mathrm{Na}$ Tabela 2 observa-se a presença de UFC na condição de regime de escoamento turbulento ( $\operatorname{Re} \approx 32000$ ), na membrana comercial sem impregnação de prata e à 1 bar (menor pressão transmembrana). Isso provavelmente ocorreu porque os poros da membrana favoreceram o transporte no início do processamento.

$\mathrm{Na}$ Tabela 2 observa-se a presença de UFC na condição de regime de escoamento turbulento ( $R e \approx 22000$ ), na membrana impregnada uma vez com prata, ocorrendo saturação à 4 bar (maior pressão transmembrana), seguida de redução à 3 bar e aumento à 2 bar. Esse comportamento de aumento à 2 bar, que foi a última pressão ensaiada, deve-se provavelmente ao crescimento de bactérias ao longo do processo de microfiltração.

Os resultados mais satisfatórios na retenção de bactérias ocorreram na 
membrana comercial de 0,8 $\mu \mathrm{m}$ impregnada com prata, em regime de escoamento turbulento de $\operatorname{Re} \approx 32000$ e de $\operatorname{Re} \approx 28000$.

Tabela 2 - Unidades formadoras de colônia por grama (UFC/g) de bactérias do grupo coliforme fecal (E. coli) presentes nos permeados correspondentes a 15 minutos de filtração para a membrana comercial de $0,8 \mu \mathrm{m}$ de tamanho médio de poros.

\begin{tabular}{|c|c|c|c|c|c|}
\hline $\begin{array}{l}\text { Número de } \\
\text { Reynolds }\end{array}$ & $\begin{array}{l}\text { Pressão: } \\
\text { 1bar }\end{array}$ & $\begin{array}{l}\text { Pressão: } \\
2 \text { bar }\end{array}$ & $\begin{array}{l}\text { Pressão: } \\
\text { 3bar }\end{array}$ & $\begin{array}{l}\text { Pressão: } \\
4 \text { bar }\end{array}$ & $\begin{array}{l}\text { Estrutura } \\
\text { cerâmica }\end{array}$ \\
\hline 32000 & $\begin{array}{c}\text { UFC } / \mathbf{g} \\
5,31\end{array}$ & $\begin{array}{c}\mathrm{UFC} / \mathbf{g} \\
0\end{array}$ & $\begin{array}{c}\mathrm{UFC} / \mathrm{g} \\
0\end{array}$ & $\begin{array}{c}\mathrm{UFC} / \mathrm{g} \\
0\end{array}$ & $\underset{\text { impreanacão }}{\text { Sem }}$ \\
\hline 32000 & 0 & 0 & 0 & 0 & $\begin{array}{c}1 \text { a. } \\
\text { impregnação }\end{array}$ \\
\hline 28000 & 0 & 0 & 0 & 0 & $\begin{array}{c}1 \mathrm{a} . \\
\text { impreanacão }\end{array}$ \\
\hline 22000 & 7,86 & 21,15 & 6,33 & saturada & $\begin{array}{c}1 \mathrm{a} . \\
\text { impregnação }\end{array}$ \\
\hline
\end{tabular}

A Tabela 3 apresenta a contagem de UFC das bactérias do grupo coliforme (E. coli) por grama de permeado coletado aos 45 minutos do processo, em diferentes pressões transmembrana e número de Reynolds, para a membrana comercial de tamanho nominal de poro igual a $0,8 \mu \mathrm{m}$ com e sem a impregnação de prata.

Observa-se na Tabela 3 a presença de UFC na membrana impregnada com prata, em regime de escoamento turbulento de $\mathrm{Re} \approx 32000$ e nas menores pressões transmembrana, seguida de redução à 3 e 4 bar.

$\mathrm{Na}$ Tabela 3 observa-se que a membrana comercial impregnada, em menor regime de escoamento turbulento $(\operatorname{Re} \approx 22000)$ apresentou maior contagem de UFC/g à 2 bar, seguida de redução nas demais pressões transmembrana. Esse comportamento indica a influência da prata, pois mesmo em pressões mais elevadas e com o aumento do tempo de filtração (45 minutos), o valor de UFC/g não ultrapassou aquele apresentado à 2 bar. Cabe ressaltar que as bactérias após 20 minutos possuem a capacidade de duplicarem a sua colônia, ou seja, aos 45 minutos, a concentração de bactérias no soro de búfala a ser filtrado era maior do que aos 15 minutos. 
Tabela 3 - Unidades formadoras de colônia por grama (UFC/g) de bactérias do grupo coliforme fecal (E. colli) presentes nos permeados correspondentes a 45 minutos de filtração para a membrana comercial de $0,8 \mu \mathrm{m}$ de tamanho médio de poros.

\begin{tabular}{|c|c|c|c|c|c|}
\hline $\begin{array}{l}\text { Número de } \\
\text { Reynolds }\end{array}$ & $\begin{array}{l}\text { Pressão: } \\
\text { 1bar }\end{array}$ & $\begin{array}{l}\text { Pressão: } \\
2 \text { bar }\end{array}$ & $\begin{array}{l}\text { Pressão: } \\
\text { 3bar }\end{array}$ & $\begin{array}{l}\text { Pressão: } \\
4 \text { bar }\end{array}$ & $\begin{array}{l}\text { Estrutura } \\
\text { cerâmica }\end{array}$ \\
\hline & UFC/g & UFC/g & UFC/g & UFC/g & \\
\hline 32000 & 0 & 0 & 0 & 0 & $\begin{array}{c}\text { Sem } \\
\text { impregnação }\end{array}$ \\
\hline 32000 & 5,65 & 7,03 & 0 & 0 & $\begin{array}{c}1 \text { a. } \\
\text { impregnação }\end{array}$ \\
\hline 28000 & 0 & 0 & 0 & 0 & $\begin{array}{c}1 \stackrel{\text { a. }}{\text { impregnação }} \\
\text { ing }\end{array}$ \\
\hline 22000 & 1,31 & 29,23 & 10,61 & 1,88 & $\begin{array}{c}1 \stackrel{\text { a. }}{\text { impregnação }} \\
\text { in }\end{array}$ \\
\hline
\end{tabular}

A Tabela 4 apresenta a amostragem do número de unidades formadoras de colônias das bactérias do grupo coliforme (E. coli) por grama de permeado coletado aos 15 minutos de processo, em diferentes pressões transmembrana e número de Reynolds, para a membrana comercial de tamanho nominal de poro igual a $1,2 \mu \mathrm{m}$, sem a impregnação de prata, com uma impregnação de prata e com duas impregnações de prata.

$\mathrm{Na}$ Tabela 4 observa-se em todos os regimes de escoamento de transição e pressões transmembrana, a presença de bactérias nos permeados coletados aos 15 minutos do processo, exceto com ausência nos experimentos que envolvem a membrana impregnada uma vez com prata.

Os maiores valores de UFC/g da Tabela 4 apresentaram-se na membrana comercial de 1,2 $\mu \mathrm{m}$ sem a impregnação de prata, ocorrendo saturação nas três condições de regime de escoamento de transição.

Observa-se na Tabela 4 a ausência de UFC/g de E. coli, na membrana comercial de 1,2 $\mu \mathrm{m}$ impregnada uma vez, independente do número de Reynolds e pressão transmembrana, indicando assim, resultados satisfatórios na retenção e/ou redução de bactérias do soro de leite. 
Tabela 4 - Unidades formadoras de colônia por grama (UFC/g) de bactérias do grupo coliforme fecal (E. coli) presentes nos permeados correspondentes a 15 minutos de filtração para a membrana comercial de $1,2 \mu \mathrm{m}$ de tamanho médio de poros.

\begin{tabular}{|c|c|c|c|c|}
\hline $\begin{array}{l}\text { Número de } \\
\text { Reynolds }\end{array}$ & $\begin{array}{l}\text { Pressão: } \\
\text { 1bar }\end{array}$ & $\begin{array}{l}\text { Pressão: } \\
2 \text { bar }\end{array}$ & $\begin{array}{l}\text { Pressão: } \\
\text { 3bar }\end{array}$ & $\begin{array}{l}\text { Estrutura } \\
\text { cerâmica }\end{array}$ \\
\hline 4200 & $\begin{array}{c}\mathbf{U F C} / \mathbf{g} \\
2,29\end{array}$ & $\begin{array}{l}\text { UFC/g } \\
\text { saturou }\end{array}$ & $\begin{array}{c}\mathbf{U F C} / \mathbf{g} \\
5,21\end{array}$ & $\begin{array}{c}\text { Sem } \\
\text { impregnação }\end{array}$ \\
\hline 4200 & 0 & 0 & 0 & $\begin{array}{c}1 \mathrm{a} . \\
\text { impregnação }\end{array}$ \\
\hline 4200 & 2,96 & 11,15 & 0,86 & impregnação \\
\hline 3500 & 5,81 & 22,09 & saturou & $\begin{array}{c}\text { Sem } \\
\text { impregnação }\end{array}$ \\
\hline 3500 & 0 & 0 & 0 & $\begin{array}{c}1 \text { a. } \\
\text { impregnação }\end{array}$ \\
\hline 3500 & 0,58 & 1,83 & 0,66 & $\begin{array}{c}2^{\mathrm{a}} \text {. } \\
\text { impregnação }\end{array}$ \\
\hline 2800 & saturou & saturou & saturou & $\begin{array}{c}\text { Sem } \\
\text { impregnação }\end{array}$ \\
\hline 2800 & 0 & 0 & 0 & $\begin{array}{c}1 \underline{\mathrm{a}} . \\
\text { impregnação }\end{array}$ \\
\hline 2800 & 0,0769 & 0 & 0 & $\begin{array}{c}2^{a} . \\
\text { impregnação }\end{array}$ \\
\hline
\end{tabular}

A Tabela 5 apresenta a amostragem do número de unidades formadoras de colônias das bactérias do grupo coliforme ( $E$. coli) por grama de permeado coletado aos 30 minutos de processo, em diferentes pressões transmembrana e número de Reynolds para a membrana comercial de tamanho nominal de poro igual a $1,2 \mu \mathrm{m}$, sem a impregnação de prata, com uma impregnação de prata e com duas impregnações de prata.

Na Tabela 5 observa-se a saturação de UFC/g em todos os regimes de escoamento de transição, na estrutura microporosa sem impregnação de prata e também em regime de escoamento de $R e \approx 4200$, na membrana impregnada duas vezes. Houve redução de UFC/g apenas na membrana impregnada duas vezes.

Observa-se na Tabela 5, ausência de UFC/g, na membrana comercial de $1,2 \mu \mathrm{m}$ impregnada uma vez, independente do número de Reynolds e 
pressão transmembrana, indicando um resultado satisfatório.

$\mathrm{Na}$ Tabela 5, na condição de regime de escoamento de transição ( $R e \approx 2800$ ), o tempo de contato entre os microrganismos em suspensão no fluido e a estrutura microporosa impregnada duas vezes foi maior, observandose uma redução satisfatória das unidades formadoras de colônia, provavelmente devido à ação da prata.

Tabela 5 - Unidades formadoras de colônia por grama (UFC/g) de bactérias do grupo coliforme fecal ( $E$. coli) presentes nos permeados correspondentes a 30 minutos de filtração para a membrana comercial de 1,2 $\mu \mathrm{m}$ de tamanho médio de poros.

\begin{tabular}{|c|c|c|c|c|}
\hline $\begin{array}{l}\text { Número de } \\
\text { Reynolds }\end{array}$ & $\begin{array}{l}\text { Pressão: } \\
\text { 1bar }\end{array}$ & $\begin{array}{l}\text { Pressão: } \\
2 \text { bar }\end{array}$ & $\begin{array}{l}\text { Pressão: } \\
\text { 3bar }\end{array}$ & $\begin{array}{l}\text { Estrutura } \\
\text { cerâmica }\end{array}$ \\
\hline 4200 & $\begin{array}{l}\mathbf{U F C} / \mathbf{g} \\
\text { saturou }\end{array}$ & $\begin{array}{l}\text { UFC/g } \\
\text { saturou }\end{array}$ & $\begin{array}{c}\mathbf{U F C} / \mathbf{g} \\
3,84\end{array}$ & $\begin{array}{c}\text { Sem } \\
\text { impregnação }\end{array}$ \\
\hline 4200 & 0 & 0 & 0 & impregnação \\
\hline 4200 & saturou & saturou & 0,22 & $\begin{array}{l}2^{\mathrm{a}} \text {. } \\
\text { impregnação }\end{array}$ \\
\hline 3500 & 9,36 & saturou & saturou & $\begin{array}{c}\text { Sem } \\
\text { impregnação }\end{array}$ \\
\hline 3500 & 0 & 0 & 0 & $\begin{array}{c}1 \mathrm{a} . \\
\text { impregnação }\end{array}$ \\
\hline 3500 & 0,17 & 0,87 & 3,30 & impregnação \\
\hline 2800 & saturou & saturou & saturou & $\begin{array}{c}\text { Sem } \\
\text { impregnação }\end{array}$ \\
\hline 2800 & 0 & 0 & 0 & $\begin{array}{c}1 \mathfrak{a} . \\
\text { impregnacão }\end{array}$ \\
\hline 2800 & 0 & 0 & 0 & $\begin{array}{l}2^{\mathrm{a}} \text {. } \\
\text { impregnação }\end{array}$ \\
\hline
\end{tabular}

$\mathrm{Na}$ Tabela 5, na condição de regime de escoamento de transição ( $R e \approx 2800$ ), onde a camada de polarização favoreceu o tempo de contato entre a bactéria e a prata, houve redução das UFC de E. coli.

As Tabelas 6 e 7 apresentam respectivamente a amostragem do número de unidades formadoras de colônias das bactérias do grupo coliforme fecal (E. 
coli) por grama de permeado coletado aos 25 minutos de processo e aos 50 minutos, em diferentes pressões transmembrana e número de Reynolds para 0 tubo microporoso de tamanho nominal de poro igual a $0,4 \mu \mathrm{m}$.

Nas Tabelas 6 e 7, em regime de escoamento turbulento de $R e \approx 21000$, observa-se a presença de UFC/g de permeado coletado aos 25 e aos 50 minutos, porém apresentando valores menores que $1 \mathrm{UFC} / \mathrm{g}$, o que ainda considera-se satisfatório quanto à retenção de bactérias.

Nas condições de regime de escoamento turbulento com $\operatorname{Re} \approx 25000$ e $\mathrm{Re} \approx 18000$ observa-se o bloqueio das bactérias, independente da pressão transmembrana e do tempo de filtração.

Tabela 6 - Unidades formadoras de colônia por grama (UFC/g) de bactérias do grupo coliforme fecal ( $E$. coli) presentes nos permeados correspondentes a 25 minutos de filtração para o tubo cerâmico de $0,4 \mu \mathrm{m}$ de tamanho médio de poros, sem a impregnação de prata metálica.

\begin{tabular}{|c|c|c|c|c|}
\hline $\begin{array}{l}\text { Número de } \\
\text { Reynolds }\end{array}$ & $\begin{array}{l}\text { Pressão: } \\
\text { 1bar }\end{array}$ & $\begin{array}{l}\text { Pressão: } \\
2 \text { bar }\end{array}$ & $\begin{array}{l}\text { Pressão: } \\
\text { 3bar }\end{array}$ & $\begin{array}{l}\text { Pressão: } \\
\text { 4bar }\end{array}$ \\
\hline 25000 & $\begin{array}{c}\mathbf{U F C} / \mathbf{g} \\
0\end{array}$ & $\begin{array}{c}\mathbf{U F C} / \mathbf{g} \\
0\end{array}$ & $\begin{array}{c}\mathbf{U F C} / \mathbf{g} \\
0\end{array}$ & $\begin{array}{c}\mathbf{U F C} / \mathbf{g} \\
0\end{array}$ \\
\hline 21000 & 0 & 0 & 0 & 0,25 \\
\hline 18000 & 0 & 0 & 0 & 0 \\
\hline
\end{tabular}

Tabela 7 - Unidades formadoras de colônia por grama (UFC/g) de bactérias do grupo coliforme fecal ( $E$. coli) presentes nos permeados correspondentes a 50 minutos de filtração para o tubo cerâmico de $0,4 \mu \mathrm{m}$ de tamanho médio de poros, sem a impregnação de prata metálica.

\begin{tabular}{c|cccc}
\hline $\begin{array}{c}\text { Número de } \\
\text { Reynolds }\end{array}$ & $\begin{array}{c}\text { Pressão: } \\
\text { 1bar }\end{array}$ & $\begin{array}{c}\text { Pressão: } \\
\text { 2 bar }\end{array}$ & $\begin{array}{c}\text { Pressão: } \\
\text { 3bar }\end{array}$ & $\begin{array}{c}\text { Pressão: } \\
\text { 4bar }\end{array}$ \\
\hline 25000 & $\begin{array}{c}\text { UFC/g } \\
\text { UFC/g } \\
\text { UFC/g }\end{array}$ & $\begin{array}{c}\text { UFC/g } \\
0\end{array}$ \\
21000 & 0 & 0,90 & 0 & 0,74 \\
18000 & 0 & 0 & 0 & 0 \\
\hline
\end{tabular}

As Tabelas 8 e 9 apresentam respectivamente a amostragem do número de unidades formadoras de colônias das bactérias do grupo coliforme fecal ( $E$. coli) por grama de permeado coletado aos 15 e 50 minutos de processo, em 
diferentes pressões transmembrana e número de Reynolds para o tubo microporoso de tamanho nominal de poro igual a $0,5 \mu \mathrm{m}$.

Observa-se nas Tabelas 8 e 9 , a retenção completa dos microrganismos, ou seja, ocorreu $100 \%$ de bloqueio das bactérias. Deve-se levar em consideração neste caso, o valor do tamanho de poro $(0,5 \mu \mathrm{m})$ e a estrutura microporosa homogênea (monocamada), capaz de bloquear bactérias cujo tamanho a princípio exceda $0,5 \mu \mathrm{m}$.

Tabela 8 - Unidades formadoras de colônia por grama (UFC/g) presentes nos permeados correspondentes a 15 minutos de filtração para o tubo cerâmico de $0,5 \mu \mathrm{m}$ de tamanho médio de poros, sem a impregnação de prata metálica.

\begin{tabular}{|c|c|c|c|c|}
\hline $\begin{array}{l}\text { Número de } \\
\text { Reynolds }\end{array}$ & $\begin{array}{l}\text { Pressão: } \\
\text { 1bar }\end{array}$ & $\begin{array}{l}\text { Pressão: } \\
2 \text { bar }\end{array}$ & $\begin{array}{c}\text { Pressão: } \\
\text { 3bar }\end{array}$ & $\begin{array}{l}\text { Pressão: } \\
\text { 4bar }\end{array}$ \\
\hline 25000 & $\begin{array}{c}\mathbf{U F C} / \mathbf{g} \\
0\end{array}$ & $\begin{array}{c}\mathrm{UFC} / \mathrm{g} \\
0\end{array}$ & $\begin{array}{c}\mathbf{U F C} / \mathbf{g} \\
0\end{array}$ & $\begin{array}{c}\mathbf{U F C} / \mathbf{g} \\
0\end{array}$ \\
\hline 21000 & 0 & 0 & 0 & 0 \\
\hline 18000 & 0 & 0 & 0 & 0 \\
\hline
\end{tabular}

Tabela 9 - Unidades formadoras de colônia por grama (UFC/g) de bactérias do grupo coliforme fecal ( $E$. coll) presentes nos permeados correspondentes a 45 minutos de filtração para o tubo cerâmico de $0,5 \mu \mathrm{m}$ de tamanho médio de poros, sem a impregnação de prata metálica.

\begin{tabular}{|c|c|c|c|c|}
\hline $\begin{array}{l}\text { Número de } \\
\text { Reynolds }\end{array}$ & $\begin{array}{l}\text { Pressão: } \\
\text { 1bar }\end{array}$ & $\begin{array}{l}\text { Pressão: } \\
2 \text { bar }\end{array}$ & $\begin{array}{l}\text { Pressão: } \\
\text { 3bar }\end{array}$ & $\begin{array}{l}\text { Pressão: } \\
\text { 4bar }\end{array}$ \\
\hline 25000 & $\begin{array}{c}\mathrm{UFC} / \mathrm{g} \\
0\end{array}$ & $\begin{array}{c}\mathrm{UFC} / \mathrm{g} \\
0\end{array}$ & $\begin{array}{c}\mathrm{UFC} / \mathrm{g} \\
0\end{array}$ & $\begin{array}{c}\mathrm{UFC} / \mathrm{g} \\
0\end{array}$ \\
\hline 21000 & 0 & 0 & 0 & 0 \\
\hline 18000 & 0 & 0 & 0 & 0 \\
\hline
\end{tabular}

Diante das análises apresentadas neste capítulo, a melhor condição de operação do processo combinada com as micro-estruturas, foi observada na membrana comercial de $0,8 \mu \mathrm{m}$ com duas impregnações e o tubo cerâmico de $0,4 \mu \mathrm{m}$.

No Anexo C são apresentados os registros fotográficos das respectivas 
análises na membrana filtrante quadriculada. Foram realizados mais de 100 registros e são apresentados apenas os padrões de maior freqüência, uma vez que muitos dos registros são semelhantes. No Anexo $C$ são referenciadas as imagens que correspondem aos dados das tabelas anteriores. 


\section{Capítulo 5}

\section{CONCLUSÕES E SUGESTÕES}

\subsection{Conclusões}

A partir da análise dos resultados experimentais desta dissertação de mestrado podemos concluir que:

- A membrana comercial que apresentou melhor desempenho no processo de microfiltração, em relação à vazão transmembrana, foi a membrana comercial de poro igual a $0,8 \mu \mathrm{m}$.

- O tubo microporoso de tamanho nominal de poro igual a 0,4 $\mu \mathrm{m}$ apresentou melhor desempenho no processo de microfiltração tangencial em relação à vazão transmembrana, quando comparado à estrutura microporosa de tamanho nominal de poro igual a 0,5 $\mu \mathrm{m}$. Isso ocorre devido à diferença da estrutura microporosa quanto à técnica de fabricação, relacionada a maior quantidade de poros no tubo microporoso de $0,4 \mu \mathrm{m}$.

- Os tubos cerâmicos de tamanho de poro 0,4 e 0,5 $\mu \mathrm{m}$ apresentaram resultados satisfatórios, retendo aproximadamente 99,9\% de bactérias em todas as condições de pressão transmembrana e número de Reynolds, sem a necessidade de impregnação.

- A membrana de tamanho nominal de poro 0,8 $4 \mathrm{~m}$ apresentou resultados significativos da influência da impregnação de prata para a redução de microrganismos do grupo coliforme fecal (E. coli) no 
processo de microfiltração tangencial em regime de escoamento turbulento na condição de $R e \approx 22000$ (Tabela 3).

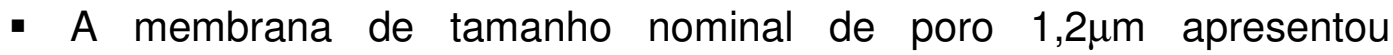
resultados significativos da influência da impregnação de prata na redução de microrganismos, principalmente na condição de menor número de Reynolds ( $\operatorname{Re} \approx 2800$ ). Neste caso, a formação da camada de polarização na superfície da membrana, aumentando o tempo de contato entre a bactéria e a prata, pode ter contribuído na redução de bactérias, como um obstáculo à passagem do material em suspensão.

- Os maiores valores na análise de resistência à formação da camada de polarização $\left(R_{C}\right)$ foram encontrados para a micro-estrutura porosa de tamanho de poro igual a $0,5 \mu \mathrm{m}$. 


\subsection{SUGESTÕES}

- Investigar a possível interferência da gordura da suspensão in natura (soro de leite) como inibidora da ação da prata;

- Investigar apropriadamente o depósito de bactérias na superfície da estrutura microporosa impregnada com prata metálica, com técnicas adequadas de microscopia;

- Investigar modelos cinéticos de redução das bactérias e da formação da camada de polarização no processamento com as estruturas microporosas.

- Estudar o permeado também através das análises de TOC, DQO e SST.

- Sinterizar tubos cerâmicos tubulares com tamanho de poros próximos a $0,8 \mu \mathrm{m}$, de modo a favorecer aumento no fluxo transmembrana e provavelmente manter 0 bom desempenho de bloqueio de microrganismos como observado no tubo de $0,5 \mu \mathrm{m}$. 


\section{REFERÊNCIAS BIBLIOGRÁFICAS}

AL-MALACK, M.H. (2003). Technical and economic aspects of crossflow microfiltration. Desalination, n.155, p.89-94.

ALVES FILHO, M. (2002). Nata do soro - Proteína retirada de subproduto do leite reforça defesa do organismo. Disponível em: <http://www.unicamp.br/unicamp/unicamp_hoje/ju/outubro2002/unihoje_ju194p ag02.html>. Acesso em: 12. fev. 2006.

ANNEAR, D.I.; MEE, N.J.; BAILEY, M. (1976). Instability and linkage of silver resistance, lactose fermentation and colony structure in Enterobacter cloacae. J. Clin. Pathol., n.29, p. 441-443.

Associação Brasileira de Criadores de Búfalos. Derivados de leite de búfalas. Disponível em: http://www.bufalo.com.br/leite.htm. Acesso em: 15.ago.2005.

BAILEY, S.M.; MEAGHER, M.M. (2000). Separation of soluble protein from inclusion bodies in Escherichia coli lysate using crossflow microfiltration. Journal of Membrane Science, n.166, p.137-146.

BAQUERO, F. (2001). Low level antibacterial resistance: a gateway to clinical resistance. Drug. Resist. Update, n. 4, p. 93-105.

BELLY, R.T.; KYDD, G.C. (1982). Silver resistance in microorganisms. Dev. Ind. Microbiol., n. 23, p. 567-577.

BOTTINO, A. et al. (1991). Pore size and pore-size distribution in microfiltration membranes. Separation Science and Technology, v. 26, p.1315-1327.

BRAGG, P.D.; RAINNIE, D.J. (1974). The effect of silver ions on the respiratory chain of E. coli. Can. J. Microbiol., n. 20, p. 883-889. 
BRITO et al. Tipos de Microrganismos. Disponível em: http://www.agencia.cnptia.embrapa.br/Agencia8/AG01/arvore/AG01_182_2172 0039246.html Acessado em: 22/11/2005.

CARIĆ, M. D., MILANOVIĆ, S.D., KRSTIĆ, D.M., TEKIĆ, M.N. (2002). Fouling of inorganic membranes by adsoption of whey proteins. Journal of Membrane of Science, n.165, p.83

CHAPPELL, J.B.; GREVILLE, G.D. (1954). Effect of silver ions on mitochondrial adenosine triphosphatase. Nature, n.174, p. 930-931.

CHERYAN, M. (1998) Ultrafiltration and Microfiltration. Tech. Publish. Comp., Lancaster, USA.

DEL COLLE, R. (2005). Desemulsificação de emulsões estáveis de água e óleo de girassol por processo de filtração tangencial. 100p. Dissertação (Mestrado), Escola de Engenharia de São Carlos, Universidade de São Paulo, São Carlos, 2005.

DESHPANDE, L.M.; CHOPADE, B.A. (1994). Plasmid mediated silver resistance in Acinetobacter baumannii. Biometals, n. 7, p. 49-56.

DEY, B.K.; HASHIM, M.A.; HASAN, S.; SEN GUPTA,B. (2004). Microfiltration of water-based paint effluents. Advances in Environmental Research, Northern Ireland, UK, n.8, p. 455-466.

DIBROV, P. et al. (2002). Chemiosmotic mechanism of antimicrobial activity of $\mathbf{A g}^{+}$in Vibrio cholerae. Antimicrobiology Agents Chemother. n. 8, p.2668-2670.

DUCLERT, F. (1989). Étude de divers phenoménes de colmatage limitant l'ecoulement de l'eau à travers une membrane minerale microporeuse. 170p. Thése (Doctorat), Academie de Montpellier - USTL - France.

FORTULAN, C. A. et al. (2005). Manufatura de membranas cerâmicas tubulares bicamadas por prensagem isostática. IN: 49ำ Congresso Brasileiro de Cerâmica. São Pedro - São Paulo, p.1-10.

FOX, R. W. \& MCDONALD, A. T. (1981). Introdução à Mecânica dos Fluidos. 2.ed. Rio de Janeiro: Guanabara Dois S.A. 
GAIGNET, Y. (2001). Purificação da água através dos tempos. Revista Meio Filtrante On-line. Disponível em: <http://www.meiofiltrante.com.br/materiais.asp ?action=detail\&id=135>. Acesso em: 21/02/2005.

GEAFILTRATION (2006). Microfiltração do soro do leite. Niro Inc. Disponível em: <http.://www.geafiltration.com/Portuguese/mercados_aplicacoe s/microfiltração_do_leite.htm>. Acesso em: 27. fev. 2006.

GUERRA, A.; JONSSON, G.; RASMUSSEN, A.; WAAGNER NIELSEN, E.; EDELSTEN, D. (1997). Low Cross-flow Velocity Microfiltration of Skim Milk for Removal of Bacterial Spores. International Dairy Journal, Denmarck, n. 7, p. 849-861.

GUPTA, A.; MAYNES, M.; SILVER, S. (1998). The effects of halides on plasmid silver resistance in Escherichia coli. Appl. Environ. Microbiol., n. 64, p. 5042-5045.

GUPTA, A. et al. (1999). Molecular basis for resistance to silver cations in Salmonella. Nat. Med., n. 5, p. 183-188.

HAMACHI, M.; MIETTON-PEUCHOT, M. (1999). Experimental investigations of cake characteristics in crossflow microfiltration. Chemical Engineering Science, n. 54, p. 4023-4030.

HANEDA, R. N. et al. (2005). Experimental study of retention of the Escherichia coli using the crossflow microfiltration with different microporous structures. $18^{\text {th }}$ International Congress of Mechanical Engineering. Associação Brasileira de Engenharia e Ciências Mecânicas. Ouro Preto Minas Gerais - BR, n. 1887, p. 82.

HAYASHI, M. et al. (1992). Properties of respiratory chain-linked Na (+)independent NADH-quinone reductase in a marine Vibrio alginolyticus. Biochim. Biophys. Acta., n. 1099, p. 145-151.

HEINIG, C.F. (1986). Composition for bacterial treatment of water. US Patent 4,608,247, 26 aug. 1986.

HENDRY, A.T.; STEWART, I.O. (1979). Silver-resistant Enterobacteriaceae from hospital patients. Can. J. Microbiol., n. 25, p. 916-921.

HENRY, J. D.; ALLRED, R. C. (1972). Concentration of bacterial cells by crossflow filtration. Development in Industrial Microbiology, v. 13, p. 177. 
HOSTYNEK, J.J. et al. (1993). Metals and the skin. Crit. Rev. Toxicol., n. 23, p. 171-235.

HUNT, J.W et al. (1987). A mathematical model of steady-state cross-flow microfiltration in a woven hose support. Journal of Desalination, v.61, n.3, cot, p. 187-200.

KAUR, P.; SAXENA, M.; VADEHRA, D.V. (1985). Plasmid mediated resistance to silver ions in Escherichia coli. Ind. J. Med. Res., n. 82, p. 122126.

KOLEGA, M. et al. (1989). Desinfection of secondary sewage effluent by advanced membrane treatment technology. In: AUSTRALIAN WATER AND WASTEWATER ASSOCIATION - $13^{\text {TH }}$ FEDERAL CONVENTION. Australia. 1989, Proceed. p.623-627.

KOLEGA, M. et al. (1991). Desinfection and clarification on treated sewage by advanced microfiltration. Water Science Technology, v.23, p.1609-1618.

KOURAI, H., MANABE, Y., YAMADA, Y. (1994). Mode of bactericidal action of zirconium phosphate ceramics containing silver íons in the crystal structure. Journal Antibact. Antifung. Agents, n.22, p.595-601

KRSTIĆ, D. M., TEKIĆ, M. N., CARIĆ, M. D., MILANOVIĆ, S. D. (2002). The effect of turbulence promoter on cross-flow microfiltration of skim milk. Journal of Membrane Science, n. 208, p. 303-314.

LACOSTE, B. (1992). Étude d'un procédé de traitement des eaux usées sur membranes minérales par couplage microfiltration ou ultrafiltration tangentielles et systèmes biologiques en aérobiose... Montpellier. 227p. Thése (Doctorat) - Université de Montpellier II - France. 1992.

LANGLAIS, B. et al. (1992). Test on microfiltration as a tertiary treatment downstream of fixed bacteria filtration. Water Sciences Technology, v.25, n.10, p.219-230.

LANGLAIS, B. et al. (1993). Microfiltration used a means of desinfection downstream: a bacterial treatment stage on fixed-bed bacteria. Water Sciences Technology, v.27, n. 7-8, p.19-27.

LAPOLLI, F. R. (1998). Biofiltração e microfiltração tangencial para tratamento de esgotos sanitários. $186 p$ + anexos. Tese (Doutorado) - Escola 
de Engenharia de São Carlos, Universidade de São Paulo, São Carlos. 1998.

LEGERON, J. P. (1993). Journée Separatec, Saint-Nazaire, Juin.

LEHNINGER, A.L. (1993). Principles of Biochemistry. Tradução de W.R. Lodi e A.A. Simões. 8.ed. São Paulo: Sarvier Editora de livros médicos Ltda.

LI, X.Z.; NIKAIDO, H.; WILLIAMS, K.E. (2003). Silver-resistant mutants of Escherichia coli display active efflux $\mathrm{Ag}+$ and are deficient in porins. J. Bacteriol., n. 19, p. 6127-6132.

LI, H.; FANE, A.G.; COSTER, H.G.L.; VIGNESWARAN,S. (2003). Observation of deposition and removal behaviour of submicron bacteria on the membrane surface during crossflow microfiltration. Journal of Membrane Science, n.217, p. 29-41.

LIGHTFOOD, E. N. (1974). Transport Phenomena and Living system - J Wiley \& Sons.

MATSUNAGA, T., TOMODA, R., NAKAJIMA, T., WAKE, H. (1985). Photoelectrochemical sterilization of microbial cells by semiconductor powders. FEMS Microbiol. Lett., n. 29, p.211-214.

MAUBOIS, J. L. et al. (2001). Milk microfiltrate, a convenient starting material for fractionation of whey proteins and derivatives. In: Proceedings of the $3^{\text {rd }}$ International Whey Conference. Munich, Chicago. American Dairy Products Institute, p. 59-72.

MCDONNELL, G.; RUSSELL, A.D. (1999). Antiseptics and disinfectants: activity, action and resistance. Clin. Microbiol. Rev., n. 12, p. 147-179.

MCHUGH, G.L. et al. (1975). Salmonella typhimurium resistance to silver nitrate, chloramphenicol, and ampicillin. Lancet., n. 1, p. 235-240.

MICHAELS, S.L. (1989) Crossflow microfilters: the ins and outs. Journal of Chemical Engineering, p. 84-9.

MITCHELL, P. (1961) Coupling of phospkorylation to electron and hydrogen transfer by a chemiosmotic type of mechanism. Nature, n. 191, p. 144-148. 
MITCHELL, P. (1966). Chemiosmotic coupling in oxidative and synthetic phosphorylation. Biol. Rev., n. 41, p. 445-502.

MOULIN, C. (1987). L'ultrafiltration et son utilisation dans lês traitement d'effluents industriels.. Montpellier. D.E.A. (Rapport). Université des Sciences et Techniques du Languedoc - France.

MUNSON, B. R.; YOUNG, D. F. \& OKIISHI, T. H. (1994). Fundamentos da Mecânica dos Fluidos. 2.ed. São Paulo: Edgard Blücher LTDA.

MURADIUM FILHO, J. (1989) Filtração convencional. Milipore Indústria e Comércio Ltda, São Paulo, 29 f. (Mimeógrafo).

NESBITT JR., R.U.; SANDMANN, B.J. (1977). Solubility studies of silver sulfadiazine. J. Pharm. Sci., n. 66, p. 519-522.

NIES, D.H. (2003). Efflux-mediated heavy metal resistance in prokaryotes. FEMS Microbiol. Rev., n. 27, p. 313-339.

PERCIVAL, S.L.; BOWLER, P.G.; RUSSELL, D. (2005). Bacterial resistance to silver in wound care. Journal of Hospital Infection, n.60, p.1-7.

PETRUS, J.C.C. (1997). Preparação, modificação e caracterização de membranas assimétricas para clarificação de suco de frutas. 139p. Tese (Doutorado) - Faculdade de Engenharia de Alimentos, Universidade Estadual de Campinas, São Paulo, 1997.

PILLAY, V.L., BUCKLEY, C.A. (1992) Cake formation in cross-flow microfiltration systems. Journal of Water Science and Technology, v.25, n.10, p. 149-162.

POULIOT, M. et al. (1995) Microfiltration on sweet whey alumina membranes: influence of the hydrodynamic conditions on the fouling. Journal Lait, v.75, n. 2, p. 117-131.

QUEIROZ, V.M.S. (2004). Estudo experimental do escoamento e da concentração de mistura no processo de filtração tangencial de sUSPensões macromoleculares. 120p. Dissertação (Mestrado) - Escola de Engenharia de São Carlos, Universidade de São Paulo, São Carlos, 2004. 
RESEARCH ON THE BENEFITS OF SILVER (2005) Louisville, K.Y. Site created by SilverHealthy. Disponível em: <http.://home.aol.com/silverhealthy /agresearch.htm>. Acesso em: 01 mar.

RESEAU NOVELECT - INNOVATION ÉNERGÉTIQUE ÉLECTRICITÉ. (1993). Les applications innovantes des techniques membranaires dans l'industrie. 60p.

REUTILIZAÇÃO DO USO DO LEITE (2000) Santa Catarina, Brasil. Departamento de Engenharia Química e Engenharia de Alimentos da UFSC. Disponível em:<http://www.ctc.ufsc.br/comunicados/releases/ago2000.htm>. Acesso em: 12 fev.

RIPPERGER, S. (1988) Engineering aspects and applications of crossflow microfiltration. Journal of Chemical Engineering and Technology, v. 11, n.1, p. 17-25.

RIPPERGER, S., ALTMANN, J. (2002). Crossflow microfiltration - state of the art. Separation and Purification Technology, n. 26, p. 19- 31.

RUSSELL, A.D.; CHOPRA, I. (1996). Understanding antibacterial action and resistance. 2 ed. Chichester: Ellis Horwood.

SALVATORE, S. (2005). Prata coloidal. Associação Brasileira de Medicina Complementar, São Paulo, 10 jan. Disponível em: <http://www.medicinacomplementar.com.br/tema100105.asp>. Acesso em: 10 mar.2005

SAVELLO, P., CARIĆ, M., MAHMOUD, P. Fouling of ceramic membrane by milk proteins during microfiltration. Aust. J. Dairy Technol., n.52, p.60.

SCHUZ, G., RIPPERGER, S. (1989) Concentration polarization in crossflow microfiltartion. Journal of Membrane Science, v. 40, p. 173-187.

SCOTT, K. (1995). Handbook of industrial membranes. Elsevier Science Publishers, Oxford.

SEMEYKINA, A.L.; SKULACHEV, V.P. (1990). Submicromolar Ag+ increases passive $\mathrm{Na}+$ permeability and inhibits the respiration-supported formation of $\mathrm{Na}+$ gradient in Bacillus FTU vesicles. FEBS Lett., n. 269, p. 69-72. 
SILVER, S. (1996). Bacterial resistance to toxic metal ions. Gene., n. 179, p. 9-19.

SILVER, S. (1998). Genes for all metals- a bacterial view of the periodic table. J. Ind. Microbiol. Biotechnol., n. 20, p. 1-12.

SILVER, S. (2003). Bacterial silver resistance: molecular biology and uses and misuses of silver compounds. FEMS Microbiol. Rev., n. 27, p. 341-353.

RUSSELL, A.D.; HUGO, W.B. (1994). Antimicrobial activity and action of silver. Prog. Med. Chem., n. 31, p. 351-370.

SGARBIERI, V. C. (2004). Propriedades fisiológicas- funcionais das proteínas do soro de leite. Revista de Nutrição, Departamento de Alimentos e Nutrição, Universidade Estadual de Campinas, n.17(4), p. 397-409.

SONDHI, R. et al. (2003). Application and benefits of ceramic membranes. Membrane Technology. Pall Corp, 1750. Filter Drive, De Land, Florida, USA

SONDI, I.; SALOPEK-SONDI, B. (2004). Silver nanoparticles as antimicrobial agent: a case study on E. coli as a model for Gram-negative bactéria - Journal of Colloid and Interface Science, n. 275, p. 177-182.

SUCHECKA, T.; BIERNACKA, E.; PIATKIEWICZ, W. (2003). Microorganism Retention on Microfiltration Membranes - Filtration more Separation Elsevier Science Ltd., ISSN 0015-1882-2003, p. 51-55.

Surel, O. M. H., Famelart (1995). Ability of ceramic membranes to reject lipids of dairy products. Aust. Journal Dairy Techonology, n.50, p.36.

VETIER, C., BENNASAR, M., TORADO DE LA FUENTE, B. (1988). Study of the fouling of a mineral microfiltration membrane using scanning electron microscopy and physicochemical analyses in the processing of milk. J. Dairy Res., n.55, p.381.

VIDAL, C.M.S. (2001). Microfiltração tangencial como alternativa de póstratamento de efluente de reator anaeróbio de leito expandido alimentado com esgoto sanitário. 147p. Dissertação (Mestrado) - Escola de Engenharia de São Carlos, Universidade de São Paulo, São Carlos, 2001.

VIOTTO, L. A. ; DA CUNHA, C. R.; VIOTTO, W. H. (2006). Use of low concentration factor ultrafiltration retentates in reduced fat "Minas 
Frescal" cheese manufacture: Effect on composition, proteolysis, viscoelastic properties and sensory acceptance. International Dairy Journal Science Direct., n.16, p.215-224.

VOGEL, A.I. (1905). Química analítica Qualitativa. 5. ed. São Paulo: Mestre Jou.

WISNIEWSKI, C. (1996). Étude du comportement de cultures mixtes en bioréacteur à membrane-cinétiques reáctionelles et filtrabilité. 174p. Thése (Doctorat) - Université de Montpellier II - Sciences et Techniques du Languedoc, France. 1992.

ZEMAN, L.J.; ZYDNEY, A.L. (1996). Microfiltration and Ultrafiltration Principles and Applications. Marcel Dekker, N.Y.

ZINSLY, P. F. et al. (2001). Produção piloto de concentrados de proteínas de leite bovino: composição e valor nutritivo. Braz. Journal Food Technology. n. 4, p.1-8. 
Anexo A - Vazão Transmembrana "J" 


\section{ANEXO A}

\section{Vazão Transmembrana “J”"}

Tabela A. 1: Tabela com os valores dos permeados coletados para o processo de microfiltração tangencial com membrana comercial $(0,8 \mu \mathrm{m}$ de tamanho médio dos poros; $190 \mathrm{~mm}$ de comprimento; 5,6 de diâmetro interno) sem impregnação de prata e regime de escoamento turbulento de $\operatorname{Re} \approx 30000$.

\begin{tabular}{c|c|c|c|c|c|c|c|c}
\hline \multirow{2}{*}{$\begin{array}{c}\text { Tempo } \\
\text { (minutos) }\end{array}$} & \multicolumn{2}{|c|}{$\mathbf{\text { bar }}$} & \multicolumn{2}{|c|}{$\mathbf{2}$ bar } & \multicolumn{2}{c|}{$\mathbf{3}$ bar } & \multicolumn{2}{c}{$\mathbf{4 ~ b a r}$} \\
\cline { 2 - 10 } & $\mathrm{J}(\mathrm{g})$ & $\mathrm{J}\left(\mathrm{L} / \mathrm{h} \cdot \mathrm{m}^{2}\right)$ & $\mathrm{J}(\mathrm{g})$ & $\mathrm{J}\left(\mathrm{L} / \mathrm{h} \cdot \mathrm{m}^{2}\right)$ & $\mathrm{J}(\mathrm{g})$ & $\mathrm{J}\left(\mathrm{L} / \mathrm{h} \cdot \mathrm{m}^{2}\right)$ & $\mathrm{J}(\mathrm{g})$ & $\mathrm{J}\left(\mathrm{L} / \mathrm{h} \cdot \mathrm{m}^{2}\right)$ \\
\hline $\mathbf{5}$ & 2,96 & 11,22 & 3,9 & 14,78 & 11,75 & 44,52 & 59,34 & 224,84 \\
\hline $\mathbf{1 0}$ & 2,90 & 10,99 & 3,47 & 13,15 & 8,39 & 31,79 & 65,16 & 246,90 \\
\hline $\mathbf{1 5}$ & 2,82 & 10,69 & 3,23 & 12,24 & 8,14 & 30,84 & 35,96 & 136,26 \\
\hline $\mathbf{2 0}$ & 3,15 & 11,94 & 3,15 & 11,94 & 7,77 & 29,44 & 48,58 & 184,07 \\
\hline $\mathbf{2 5}$ & 3,18 & 12,05 & 3,03 & 11,48 & 7,75 & 29,37 & 24,23 & 91,81 \\
\hline $\mathbf{3 0}$ & 3,35 & 12,69 & 3,32 & 12,58 & 8,27 & 31,34 & 23,03 & 87,26 \\
\hline $\mathbf{3 5}$ & 3,75 & 14,21 & 3,38 & 12,81 & 7,67 & 29,06 & 21,69 & 82,19 \\
\hline $\mathbf{4 0}$ & 3,67 & 13,91 & 2,65 & 10,04 & 7,27 & 27,55 & 22,84 & 86,54 \\
\hline $\mathbf{4 5}$ & 3,46 & 13,11 & 2,67 & 10,12 & 8,10 & 30,69 & 13,39 & 50,74 \\
\hline $\mathbf{5 0}$ & 4,10 & 15,54 & 2,8 & 10,61 & 7,20 & 27,28 & 21,40 & 81,09 \\
\hline
\end{tabular}

Tabela A. 2 - Tabela com os valores dos permeados coletados para o processo de microfiltração tangencial com membrana comercial $(0,8 \mu \mathrm{m}$ de tamanho médio dos poros; 190mm de comprimento; 5,6 de diâmetro interno) com impregnação de prata e regime de escoamento turbulento de $\operatorname{Re} \approx 32000$.

\begin{tabular}{c|c|c|c|c|c|c|c|c}
\hline \multirow{2}{*}{$\begin{array}{c}\text { Tempo } \\
\text { (minutos) }\end{array}$} & \multicolumn{2}{|c|}{$\mathbf{1}$ bar } & \multicolumn{2}{|c|}{$\mathbf{2}$ bar } & \multicolumn{2}{c|}{$\mathbf{3}$ bar } & \multicolumn{2}{|c}{$\mathbf{4 ~ b a r}$} \\
\cline { 2 - 9 } & $\mathrm{J}(\mathrm{g})$ & $\mathrm{J}\left(\mathrm{L} / \mathrm{h} \cdot \mathrm{m}^{2}\right)$ & $\mathrm{J}(\mathrm{g})$ & $\mathrm{J}\left(\mathrm{L} / \mathrm{h} \cdot \mathrm{m}^{2}\right)$ & $\mathrm{J}(\mathrm{g})$ & $\mathrm{J}\left(\mathrm{L} / \mathrm{h} \cdot \mathrm{m}^{2}\right)$ & $\mathrm{J}(\mathrm{g})$ & $\mathrm{J}\left(\mathrm{L} / \mathrm{h} \cdot \mathrm{m}^{2}\right)$ \\
\hline $\mathbf{5}$ & 4,63 & 17,54 & 3,77 & 14,28 & 16,65 & 63,09 & 79,37 & 300,74 \\
\hline $\mathbf{1 0}$ & 3,98 & 15,08 & 3,81 & 14,44 & 15,60 & 59,11 & 61,19 & 231,85 \\
\hline $\mathbf{1 5}$ & 3,99 & 15,12 & 3,71 & 14,06 & 12,06 & 45,70 & 52,26 & 198,02 \\
\hline $\mathbf{2 0}$ & 3,93 & 14,89 & 3,61 & 13,68 & 10,40 & 39,41 & 45,16 & 171,11 \\
\hline $\mathbf{2 5}$ & 4,05 & 15,35 & 3,90 & 14,78 & 8,90 & 33,72 & 42,72 & 161,87 \\
\hline $\mathbf{3 0}$ & 3,95 & 14,97 & 3,76 & 14,25 & 7,85 & 29,74 & 35,96 & 136,26 \\
\hline $\mathbf{3 5}$ & 4,11 & 15,57 & 3,82 & 14,47 & 7,41 & 28,08 & 33,91 & 128,49 \\
\hline $\mathbf{4 0}$ & 4,11 & 15,57 & 3,69 & 13,98 & 7,15 & 27,09 & 32,67 & 123,79 \\
\hline $\mathbf{4 5}$ & 4,13 & 15,65 & 3,59 & 13,60 & 6,73 & 25,50 & 30,55 & 115,76 \\
\hline $\mathbf{5 0}$ & 4,25 & 16,10 & 3,70 & 14,02 & 6,65 & 25,20 & 29,55 & 111,97 \\
\hline
\end{tabular}


Tabela A. 3 - Tabela com os valores dos permeados coletados para o processo de microfiltração tangencial com membrana comercial $(0,8 \mu \mathrm{m}$ de tamanho médio dos poros; 190mm de comprimento; 5,6 de diâmetro interno) com impregnação de prata e regime de escoamento turbulento de $\operatorname{Re} \approx 27000$.

\begin{tabular}{c|c|c|c|c|c|c|c|c}
\hline \multirow{2}{*}{$\begin{array}{c}\text { Tempo } \\
\text { (minutos) }\end{array}$} & \multicolumn{2}{|c|}{$\mathbf{1}$ bar } & \multicolumn{2}{|c|}{$\mathbf{2 ~ b a r}$} & \multicolumn{2}{|c|}{ 3 bar } & \multicolumn{2}{c}{$\mathbf{4}$ bar } \\
\cline { 2 - 9 } & $\mathrm{J}(\mathrm{g})$ & $\mathrm{J}\left(\mathrm{L} / \mathrm{h} \cdot \mathrm{m}^{2}\right)$ & $\mathrm{J}(\mathrm{g})$ & $\mathrm{J}\left(\mathrm{L} / \mathrm{h} \cdot \mathrm{m}^{2}\right)$ & $\mathrm{J}(\mathrm{g})$ & $\mathrm{J}\left(\mathrm{L} / \mathrm{h} \cdot \mathrm{m}^{2}\right)$ & $\mathrm{J}(\mathrm{g})$ & $\mathrm{J}\left(\mathrm{L} / \mathrm{h} \cdot \mathrm{m}^{2}\right)$ \\
\hline $\mathbf{5}$ & 3,52 & 13,34 & 3,04 & 11,52 & 7,17 & 27,17 & 41,73 & 158,12 \\
\hline $\mathbf{1 0}$ & 3,30 & 12,50 & 3,07 & 11,63 & 6,41 & 24,29 & 30,82 & 116,78 \\
\hline $\mathbf{1 5}$ & 2,99 & 11,33 & 2,52 & 9,55 & 6,35 & 24,06 & 27,45 & 104,01 \\
\hline $\mathbf{2 0}$ & 2,82 & 10,69 & 2,59 & 9,81 & 6,08 & 23,04 & 23,74 & 89,95 \\
\hline $\mathbf{2 5}$ & 2,77 & 10,50 & 2,50 & 9,47 & 5,95 & 22,55 & 41,23 & 156,22 \\
\hline $\mathbf{3 0}$ & 2,93 & 11,10 & 2,43 & 9,21 & 5,85 & 22,17 & 17,63 & 66,80 \\
\hline $\mathbf{3 5}$ & 2,89 & 10,95 & 2,38 & 9,02 & 5,67 & 21,48 & 17,67 & 66,95 \\
\hline $\mathbf{4 0}$ & 2,99 & 11,33 & 2,40 & 9,09 & 5,55 & 21,03 & 16,97 & 64,30 \\
\hline $\mathbf{4 5}$ & 3,13 & 11,86 & 2,40 & 9,09 & 5,55 & 21,03 & 6,09 & 23,08 \\
\hline $\mathbf{5 0}$ & 3,06 & 11,59 & 2,35 & 8,90 & 5,25 & 16,58 & 13,39 & 50,74 \\
\hline
\end{tabular}

Tabela A. 4 - Tabela com os valores dos permeados coletados para o processo de microfiltração tangencial com membrana comercial $(0,8 \mu \mathrm{m}$ de tamanho médio dos poros; 190mm de comprimento; 5,6 de diâmetro interno) com impregnação de prata e regime de escoamento turbulento de $\mathrm{Re} \approx 22000$.

\begin{tabular}{c|c|c|c|c|c|c|c|c}
\hline \multirow{2}{*}{$\begin{array}{c}\text { Tempo } \\
\text { (minutos) }\end{array}$} & \multicolumn{2}{|c|}{$\mathbf{1}$ bar } & \multicolumn{2}{|c|}{$\mathbf{2}$ bar } & \multicolumn{2}{c|}{ 3 bar } & \multicolumn{2}{c}{$\mathbf{4}$ bar } \\
\cline { 2 - 9 } & $\mathrm{J}(\mathrm{g})$ & $\mathrm{J}\left(\mathrm{L} / \mathrm{h} \cdot \mathrm{m}^{2}\right)$ & $\mathrm{J}(\mathrm{g})$ & $\mathrm{J}\left(\mathrm{L} / \mathrm{h} \cdot \mathrm{m}^{2}\right)$ & $\mathrm{J}(\mathrm{g})$ & $\mathrm{J}\left(\mathrm{L} / \mathrm{h} \cdot \mathrm{m}^{2}\right)$ & $\mathrm{J}(\mathrm{g})$ & $\mathrm{J}\left(\mathrm{L} / \mathrm{h} \cdot \mathrm{m}^{2}\right)$ \\
\hline $\mathbf{5}$ & 0,49 & 1,86 & 0,36 & 1,36 & 0,95 & 3,60 & 12,15 & 46,04 \\
\hline $\mathbf{1 0}$ & 4,15 & 15,72 & 0,22 & 0,83 & 0,80 & 3,03 & 6,54 & 24,78 \\
\hline $\mathbf{1 5}$ & 4,20 & 15,91 & 0,52 & 1,97 & 0,79 & 2,99 & 4,45 & 16,86 \\
\hline $\mathbf{2 0}$ & 3,08 & 11,67 & 0,26 & 0,99 & 0,79 & 2,99 & 2,73 & 10,34 \\
\hline $\mathbf{2 5}$ & 2,55 & 9,66 & 0,30 & 1,14 & 0,67 & 2,54 & 2,49 & 9,43 \\
\hline $\mathbf{3 0}$ & 2,33 & 8,83 & 0,36 & 1,36 & 0,71 & 2,69 & 2,20 & 8,34 \\
\hline $\mathbf{3 5}$ & 2,09 & 7,92 & 0,26 & 0,99 & 0,74 & 2,80 & 1,91 & 7,24 \\
\hline $\mathbf{4 0}$ & 1,47 & 5,57 & 0,44 & 1,67 & 0,63 & 2,39 & 1,89 & 7,16 \\
\hline $\mathbf{4 5}$ & 1,85 & 7,01 & 0,65 & 2,46 & 0,66 & 2,50 & 1,80 & 6,82 \\
\hline $\mathbf{5 0}$ & 1,52 & 5,76 & - & - & 0,66 & 2,50 & 1,61 & 6,10 \\
\hline
\end{tabular}


Tabela A. 5 - Tabela com os valores dos permeados coletados para o processo de microfiltração tangencial com membrana comercial sem impregnação de prata, com $1,2 \mu \mathrm{m}$ de tamanho médio dos poros; $400 \mathrm{~mm}$ de comprimento; $6,0 \mathrm{~mm}$ de diâmetro interno em regime de escoamento de transição de $\mathrm{Re} \approx 4000$.

\begin{tabular}{c|c|c|c|c|c|c}
\hline \multirow{2}{*}{$\begin{array}{c}\text { Tempo } \\
\text { (minutos) }\end{array}$} & \multicolumn{2}{|c|}{$\mathbf{1}$ bar } & \multicolumn{2}{|c}{$\mathbf{2 ~ b a r}$} & \multicolumn{2}{|c}{$\mathbf{3}$ bar } \\
\cline { 2 - 7 } & $\mathrm{J}(\mathrm{g})$ & $\mathrm{J}\left(\mathrm{L} / \mathrm{h} \cdot \mathrm{m}^{2}\right)$ & $\mathrm{J}(\mathrm{g})$ & $\mathrm{J}\left(\mathrm{L} / \mathrm{h} \cdot \mathrm{m}^{2}\right)$ & $\mathrm{J}(\mathrm{g})$ & $\mathrm{J}\left(\mathrm{L} / \mathrm{h} \cdot \mathrm{m}^{2}\right)$ \\
\hline $\mathbf{1}$ & 11,96 & 13,60 & 8,89 & 10,11 & 16,10 & 18,3 \\
\hline $\mathbf{2}$ & 8,95 & 10,18 & 9,41 & 10,7 & 14,84 & 16,87 \\
\hline $\mathbf{3}$ & 7,38 & 8,39 & 8,45 & 9,61 & 14,30 & 16,26 \\
\hline $\mathbf{4}$ & 8,01 & 9,11 & 8,86 & 10,07 & 16,66 & 18,94 \\
\hline $\mathbf{5}$ & 7,98 & 9,07 & 9,06 & 10,3 & 11,25 & 12,79 \\
\hline $\mathbf{6}$ & 7,91 & 8,99 & 8,74 & 9,94 & 13,83 & 15,72 \\
\hline $\mathbf{7}$ & 9,15 & 10,40 & 8,81 & 10,02 & 13,99 & 15,9 \\
\hline $\mathbf{8}$ & 6,85 & 7,79 & 8,57 & 9,74 & 14,15 & 16,09 \\
\hline $\mathbf{9}$ & 7,42 & 8,44 & 8,68 & 9,87 & 13,51 & 15,36 \\
\hline $\mathbf{1 0}$ & 7,54 & 8,57 & 8,83 & 10,04 & 13,26 & 15,07 \\
\hline $\mathbf{1 1}$ & 7,59 & 8,63 & 8,90 & 10,12 & 14,66 & 16,67 \\
\hline $\mathbf{1 2}$ & 7,51 & 8,54 & 8,90 & 10,12 & 13,32 & 15,14 \\
\hline $\mathbf{1 3}$ & 7,65 & 8,70 & 8,80 & 10,0 & 12,92 & 14,69 \\
\hline $\mathbf{1 4}$ & 8,15 & 9,27 & 9,24 & 10,50 & 10,05 & 11,43 \\
\hline $\mathbf{1 5}$ & 6,12 & 6,96 & 8,83 & 10,04 & 11,90 & 13,53 \\
\hline $\mathbf{1 6}$ & 7,02 & 7,98 & 9,39 & 10,68 & 12,67 & 14,4 \\
\hline $\mathbf{1 7}$ & 7,67 & 8,72 & 9,02 & 10,25 & 7,49 & 8,52 \\
\hline $\mathbf{1 8}$ & 7,37 & 8,38 & 8,90 & 10,12 & 14,37 & 16,34 \\
\hline $\mathbf{1 9}$ & 7,28 & 8,28 & 8,92 & 10,14 & 11,99 & 13,63 \\
\hline $\mathbf{2 0}$ & 6,58 & 7,48 & 8,95 & 10,18 & 12,83 & 14,59 \\
\hline $\mathbf{2 1}$ & 6,53 & 7,42 & 8,97 & 10,20 & 12,21 & 13,88 \\
\hline $\mathbf{2 2}$ & 6,71 & 7,63 & 9,10 & 10,35 & 12,22 & 13,89 \\
\hline $\mathbf{2 3}$ & 6,77 & 7,70 & 9,21 & 10,47 & 12,34 & 14,03 \\
\hline $\mathbf{2 4}$ & 6,81 & 7,74 & 9,03 & 10,27 & 12,66 & 14,39 \\
\hline $\mathbf{2 5}$ & 6,75 & 7,67 & 9,25 & 10,52 & 12,01 & 13,65 \\
\hline $\mathbf{2 6}$ & 6,89 & 7,83 & 9,15 & 10,40 & 11,99 & 13,63 \\
\hline $\mathbf{2 7}$ & 6,93 & 7,88 & 9,08 & 10,32 & 12,13 & 13,79 \\
\hline $\mathbf{2 8}$ & 6,87 & 7,81 & 8,74 & 9,94 & 11,91 & 13,54 \\
\hline $\mathbf{2 9}$ & 7,12 & 8,09 & 9,49 & 10,79 & 12,07 & 13,72 \\
\hline $\mathbf{3 0}$ & 6,96 & 7,91 & 9,40 & 10,69 & 12,23 & 13,9 \\
\hline & & & & & & \\
\hline
\end{tabular}


Tabela A. 6 - Tabela com os valores dos permeados coletados para o processo de microfiltração tangencial com membrana comercial sem impregnação de prata, com $1,2 \mu \mathrm{m}$ de tamanho médio dos poros; $400 \mathrm{~mm}$ de comprimento; $6,0 \mathrm{~mm}$ de diâmetro interno em regime de escoamento de transição de $\mathrm{Re} \approx 3500$.

\begin{tabular}{c|c|c|c|c|c|c}
\hline \multirow{2}{*}{ Tempo (minutos) } & \multicolumn{2}{|c|}{$\mathbf{1}$ bar } & \multicolumn{2}{|c|}{$\mathbf{2 ~ b a r}$} & \multicolumn{2}{|c}{$\mathbf{3}$ bar } \\
\cline { 2 - 7 } & $\mathrm{J}(\mathrm{g})$ & $\mathrm{J}\left(\mathrm{L} / \mathrm{h} \cdot \mathrm{m}^{2}\right)$ & $\mathrm{J}(\mathrm{g})$ & $\mathrm{J}\left(\mathrm{L} / \mathrm{h} \cdot \mathrm{m}^{2}\right)$ & $\mathrm{J}(\mathrm{g})$ & $\mathrm{J}\left(\mathrm{L} / \mathrm{h} \cdot \mathrm{m}^{2}\right)$ \\
\hline $\mathbf{1}$ & 5,15 & 5,86 & 7,30 & 8,30 & 9,71 & 11,04 \\
\hline $\mathbf{2}$ & 5,17 & 5,88 & 7,32 & 8,32 & 9,07 & 10,31 \\
\hline $\mathbf{3}$ & 5,59 & 6,36 & 7,32 & 8,32 & 9,04 & 10,28 \\
\hline $\mathbf{4}$ & 4,91 & 5,58 & 7,40 & 8,41 & 9,09 & 10,33 \\
\hline $\mathbf{5}$ & 5,35 & 6,08 & 7,29 & 8,29 & 9,2 & 10,46 \\
\hline $\mathbf{6}$ & 5,35 & 6,08 & 7,35 & 8,36 & 8,84 & 10,05 \\
\hline $\mathbf{7}$ & 5,23 & 5,95 & 7,36 & 8,37 & 8,89 & 10,11 \\
\hline $\mathbf{8}$ & 4,92 & 5,59 & 7,23 & 8,22 & 8,86 & 10,07 \\
\hline $\mathbf{9}$ & 5,28 & 6,0 & 7,39 & 8,40 & 8,87 & 10,08 \\
\hline $\mathbf{1 0}$ & 5,37 & 6,11 & 7,35 & 8,36 & 8,9 & 10,12 \\
\hline $\mathbf{1 1}$ & 5,31 & 6,04 & 7,34 & 8,34 & 9,09 & 10,33 \\
\hline $\mathbf{1 2}$ & 3,93 & 4,47 & 7,44 & 8,46 & 8,64 & 9,82 \\
\hline $\mathbf{1 3}$ & 5,13 & 5,83 & 7,41 & 8,42 & 8,8 & 10,0 \\
\hline $\mathbf{1 4}$ & 4,79 & 5,45 & 5,66 & 6,43 & 9,02 & 10,25 \\
\hline $\mathbf{1 5}$ & 4,99 & 5,67 & 6,88 & 7,82 & 8,85 & 10,06 \\
\hline $\mathbf{1 6}$ & 5,03 & 5,72 & 7,02 & 7,98 & 8,85 & 10,06 \\
\hline $\mathbf{1 7}$ & 4,89 & 5,56 & 7,12 & 8,09 & 8,74 & 9,94 \\
\hline $\mathbf{1 8}$ & 4,98 & 5,66 & 7,15 & 8,13 & 8,86 & 10,07 \\
\hline $\mathbf{1 9}$ & 5,02 & 5,71 & 7,41 & 8,42 & 9,13 & 10,38 \\
\hline $\mathbf{2 0}$ & 5,15 & 5,86 & 7,24 & 8,23 & 8,91 & 10,13 \\
\hline $\mathbf{2 1}$ & 5,08 & 5,78 & 7,42 & 8,44 & 9,28 & 10,55 \\
\hline $\mathbf{2 2}$ & 5,09 & 5,79 & 7,20 & 8,19 & 8,84 & 10,05 \\
\hline $\mathbf{2 3}$ & 4,91 & 5,58 & 7,16 & 8,14 & 8,78 & 9,98 \\
\hline $\mathbf{2 4}$ & 5,03 & 5,72 & 7,42 & 8,44 & 9,17 & 10,43 \\
\hline $\mathbf{2 5}$ & 4,99 & 5,67 & 7,20 & 8,19 & 8,68 & 9,87 \\
\hline $\mathbf{2 6}$ & 5,05 & 5,74 & 7,08 & 8,05 & 8,88 & 10,10 \\
\hline $\mathbf{2 7}$ & 5,02 & 5,71 & 7,27 & 8,27 & 8,83 & 10,04 \\
\hline $\mathbf{2 8}$ & 5,13 & 5,83 & 7,27 & 8,27 & 8,87 & 10,08 \\
\hline $\mathbf{2 9}$ & 4,84 & 5,50 & 7,24 & 8,23 & 8,99 & 10,22 \\
\hline $\mathbf{3 0}$ & 5,13 & 5,83 & 7,22 & 8,21 & 8,88 & 10,10 \\
\hline & & & & & & \\
\hline & & & & \\
\hline & & & & & \\
\hline
\end{tabular}


Tabela A. 7 - Tabela com os valores dos permeados coletados para o processo de microfiltração tangencial com membrana comercial sem impregnação de prata, com $1,2 \mu \mathrm{m}$ de tamanho médio dos poros; $400 \mathrm{~mm}$ de comprimento; $6,0 \mathrm{~mm}$ de diâmetro interno em regime de escoamento de transição de $\mathrm{Re} \approx 3000$.

\begin{tabular}{c|c|c|c|c|c|c}
\hline \multirow{2}{*}{ Tempo (minutos) } & \multicolumn{2}{|c|}{$\mathbf{1}$ bar } & \multicolumn{2}{|c|}{$\mathbf{2 ~ b a r}$} & \multicolumn{2}{|c}{$\mathbf{3}$ bar } \\
\cline { 2 - 7 } & $\mathrm{J}(\mathrm{g})$ & $\mathrm{J}\left(\mathrm{L} / \mathrm{h} \cdot \mathrm{m}^{2}\right)$ & $\mathrm{J}(\mathrm{g})$ & $\left.\mathrm{J}\left(\mathrm{L} / \mathrm{h}^{2}\right)^{2}\right)$ & $\mathrm{J}(\mathrm{g})$ & $\mathrm{J}\left(\mathrm{L} / \mathrm{h} \cdot \mathrm{m}^{2}\right)$ \\
\hline $\mathbf{1}$ & 4,63 & 5,26 & 5,83 & 6,63 & 8,79 & 9,99 \\
\hline $\mathbf{2}$ & 4,66 & 5,30 & 5,72 & 6,50 & 8,63 & 9,81 \\
\hline $\mathbf{3}$ & 4,76 & 5,41 & 6,55 & 7,47 & 8,73 & 9,92 \\
\hline $\mathbf{4}$ & 4,93 & 5,61 & 5,55 & 6,31 & 8,24 & 9,37 \\
\hline $\mathbf{5}$ & 4,68 & 5,32 & 5,33 & 6,06 & 8,23 & 9,36 \\
\hline $\mathbf{6}$ & 4,88 & 5,55 & 6,10 & 6,94 & 8,53 & 9,70 \\
\hline $\mathbf{7}$ & 4,76 & 5,41 & 5,84 & 6,64 & 7,92 & 9,0 \\
\hline $\mathbf{8}$ & 4,99 & 5,67 & 6,54 & 7,44 & 8,03 & 9,13 \\
\hline $\mathbf{9}$ & 5,01 & 5,70 & 5,39 & 6,13 & 7,92 & 9,0 \\
\hline $\mathbf{1 0}$ & 5,05 & 5,74 & 6,14 & 6,98 & 7,84 & 8,91 \\
\hline $\mathbf{1 1}$ & 5,32 & 6,05 & 6,17 & 7,01 & 7,77 & 8,83 \\
\hline $\mathbf{1 2}$ & 4,79 & 5,45 & 6,16 & 7,0 & 7,84 & 8,91 \\
\hline $\mathbf{1 3}$ & 5,28 & 6,0 & 6,10 & 6,94 & 7,56 & 8,59 \\
\hline $\mathbf{1 4}$ & 5,36 & 6,10 & 6,13 & 6,97 & 7,62 & 8,66 \\
\hline $\mathbf{1 5}$ & 5,22 & 5,93 & 6,29 & 7,15 & 7,77 & 8,83 \\
\hline $\mathbf{1 6}$ & 5,07 & 5,76 & 5,93 & 6,74 & 7,47 & 8,49 \\
\hline $\mathbf{1 7}$ & 5,53 & 6,29 & 6,25 & 7,11 & 7,59 & 8,63 \\
\hline $\mathbf{1 8}$ & 5,18 & 5,89 & 6,18 & 7,03 & 7,48 & 8,50 \\
\hline $\mathbf{1 9}$ & 5,25 & 5,97 & 6,11 & 6,95 & 7,48 & 8,50 \\
\hline $\mathbf{2 0}$ & 5,34 & 6,07 & 6,19 & 7,04 & 7,06 & 8,03 \\
\hline $\mathbf{2 1}$ & 5,29 & 6,01 & 6,19 & 7,04 & 7,53 & 8,56 \\
\hline $\mathbf{2 2}$ & 5,12 & 5,82 & 6,24 & 7,09 & 6,89 & 7,83 \\
\hline $\mathbf{2 3}$ & 5,18 & 5,89 & 6,06 & 6,89 & 7,22 & 8,21 \\
\hline $\mathbf{2 4}$ & 5,21 & 5,92 & 6,26 & 7,12 & 7,08 & 8,05 \\
\hline $\mathbf{2 5}$ & 5,28 & 6,0 & 6,14 & 6,98 & 7,35 & 8,36 \\
\hline $\mathbf{2 6}$ & 5,32 & 6,05 & 6,0 & 6,82 & 7,27 & 8,27 \\
\hline $\mathbf{2 7}$ & 5,20 & 5,91 & 6,24 & 7,09 & 7,22 & 8,21 \\
\hline $\mathbf{2 8}$ & 5,21 & 5,92 & 5,79 & 6,58 & 7,21 & 8,20 \\
\hline $\mathbf{2 9}$ & 5,36 & 6,09 & 6,24 & 7,09 & 7,19 & 8,17 \\
\hline $\mathbf{3 0}$ & 5,29 & 6,01 & 6,21 & 7,06 & 7,49 & 8,52 \\
\hline & & & & & & \\
\hline & & & & \\
\hline & & & & & \\
\hline
\end{tabular}


Tabela A. 8 - Tabela com os valores dos permeados coletados para o processo de microfiltração tangencial com membrana comercial com a primeira impregnação de prata, com 1,2 $\mu \mathrm{m}$ de tamanho médio dos poros; $200 \mathrm{~mm}$ de comprimento; $6,0 \mathrm{~mm}$ de diâmetro interno em regime de escoamento de transição de $\mathrm{Re} \approx 4000$.

\begin{tabular}{c|c|c|c|c|c|c}
\hline \multirow{2}{*}{ Tempo (minutos) } & \multicolumn{2}{|c|}{$\mathbf{1}$ bar } & \multicolumn{2}{|c|}{$\mathbf{2 ~ b a r}$} & \multicolumn{2}{|c}{$\mathbf{3}$ bar } \\
\cline { 2 - 7 } & $\mathrm{J}(\mathrm{g})$ & $\mathrm{J}\left(\mathrm{L} / \mathrm{h}^{2} \mathrm{~m}^{2}\right)$ & $\mathrm{J}(\mathrm{g})$ & $\mathrm{J}\left(\mathrm{L} / \mathrm{h}^{2} \mathrm{~m}^{2}\right)$ & $\mathrm{J}(\mathrm{g})$ & $\mathrm{J}\left(\mathrm{L} / \mathrm{h} \cdot \mathrm{m}^{2}\right)$ \\
\hline $\mathbf{1}$ & 7,07 & 16,08 & 7,39 & 16,81 & 6,24 & 14,19 \\
\hline $\mathbf{2}$ & 6,98 & 15,88 & 6,64 & 15,10 & 6,53 & 14,85 \\
\hline $\mathbf{3}$ & 6,75 & 15,35 & 5,89 & 13,40 & 6,56 & 14,92 \\
\hline $\mathbf{4}$ & 5,74 & 13,06 & 6,16 & 14,01 & 6,01 & 13,67 \\
\hline $\mathbf{5}$ & 5,87 & 13,35 & 5,78 & 13,15 & 5,66 & 12,88 \\
\hline $\mathbf{6}$ & 5,56 & 12,65 & 5,72 & 13,01 & 5,78 & 13,15 \\
\hline $\mathbf{7}$ & 5,34 & 12,15 & 5,78 & 13,15 & 5,59 & 12,72 \\
\hline $\mathbf{8}$ & 5,12 & 11,65 & 5,41 & 12,31 & 5,51 & 12,53 \\
\hline $\mathbf{9}$ & 5,28 & 12,01 & 5,33 & 12,12 & 5,63 & 12,81 \\
\hline $\mathbf{1 0}$ & 4,99 & 11,35 & 5,31 & 12,08 & 5,63 & 12,81 \\
\hline $\mathbf{1 1}$ & 4,92 & 11,19 & 5,70 & 12,97 & 5,4 & 12,28 \\
\hline $\mathbf{1 2}$ & 4,66 & 10,60 & 5,78 & 13,15 & 5,98 & 13,60 \\
\hline $\mathbf{1 3}$ & 4,57 & 10,40 & 4,84 & 11,01 & 5,42 & 12,33 \\
\hline $\mathbf{1 4}$ & 4,45 & 10,12 & 5,34 & 12,15 & 5,26 & 11,97 \\
\hline $\mathbf{1 5}$ & 3,07 & 6,98 & 5,09 & 11,58 & 5,71 & 12,99 \\
\hline $\mathbf{1 6}$ & 4,71 & 10,71 & 4,94 & 11,24 & 6,0 & 13,65 \\
\hline $\mathbf{1 7}$ & 4,80 & 10,92 & 5,46 & 12,42 & 5,01 & 11,40 \\
\hline $\mathbf{1 8}$ & 5,12 & 11,65 & 4,86 & 11,06 & 4,98 & 11,33 \\
\hline $\mathbf{1 9}$ & 4,27 & 9,71 & 4,94 & 11,24 & 5,25 & 11,94 \\
\hline $\mathbf{2 0}$ & 4,82 & 10,96 & 5,01 & 11,40 & 5,34 & 12,15 \\
\hline $\mathbf{2 1}$ & 4,94 & 11,24 & 4,66 & 10,60 & 5,58 & 12,69 \\
\hline $\mathbf{2 2}$ & 4,46 & 10,15 & 4,91 & 11,17 & 5,2 & 11,83 \\
\hline $\mathbf{2 3}$ & 4,54 & 10,33 & 4,82 & 10,96 & 5,09 & 11,58 \\
\hline $\mathbf{2 4}$ & 4,49 & 10,21 & 4,72 & 10,74 & 5,32 & 12,10 \\
\hline $\mathbf{2 5}$ & 4,37 & 9,94 & 4,96 & 11,28 & 5,25 & 11,94 \\
\hline $\mathbf{2 6}$ & 4,22 & 9,60 & 4,45 & 10,12 & 5,05 & 11,49 \\
\hline $\mathbf{2 7}$ & 4,5 & 10,24 & 5,03 & 11,44 & 5,19 & 11,81 \\
\hline $\mathbf{2 8}$ & 4,28 & 9,74 & 5,0 & 11,37 & 5,71 & 12,99 \\
\hline $\mathbf{2 9}$ & 4,17 & 9,49 & 4,39 & 9,99 & 4,72 & 10,74 \\
\hline $\mathbf{3 0}$ & 3,93 & 8,94 & 5,97 & 13,58 & 5,64 & 12,83 \\
\hline & & & & & & \\
\hline & & & & \\
\hline & & & & & \\
\hline & & & & & &
\end{tabular}


Tabela A. 9 - Tabela com os valores dos permeados coletados para o processo de microfiltração tangencial com membrana comercial com a primeira impregnação de prata, com 1,2 $\mu \mathrm{m}$ de tamanho médio dos poros; $200 \mathrm{~mm}$ de comprimento; $6,0 \mathrm{~mm}$ de diâmetro interno em regime de escoamento de transição de $R e \approx 3500$.

\begin{tabular}{c|c|c|c|c|c|c}
\hline \multirow{2}{*}{ Tempo (minutos) } & \multicolumn{2}{|c|}{$\mathbf{1}$ bar } & \multicolumn{2}{|c|}{$\mathbf{2 ~ b a r}$} & \multicolumn{2}{|c}{$\mathbf{3}$ bar } \\
\cline { 2 - 7 } & $\mathrm{J}(\mathrm{g})$ & $\mathrm{J}\left(\mathrm{L} / \mathrm{h} \cdot \mathrm{m}^{2}\right)$ & $\mathrm{J}(\mathrm{g})$ & $\mathrm{J}\left(\mathrm{L} / \mathrm{h} \cdot \mathrm{m}^{2}\right)$ & $\mathrm{J}(\mathrm{g})$ & $\mathrm{J}\left(\mathrm{L} / \mathrm{h} \cdot \mathrm{m}^{2}\right)$ \\
\hline $\mathbf{1}$ & 2,64 & 6,01 & 3,15 & 7,17 & 7,87 & 17,90 \\
\hline $\mathbf{2}$ & 2,91 & 6,62 & 2,96 & 6,73 & 7,23 & 16,45 \\
\hline $\mathbf{3}$ & 2,84 & 6,46 & 2,97 & 6,76 & 4,25 & 9,67 \\
\hline $\mathbf{4}$ & 3,02 & 6,87 & 2,79 & 6,35 & 4,73 & 10,76 \\
\hline $\mathbf{5}$ & 2,71 & 6,16 & 2,91 & 6,62 & 4,78 & 10,87 \\
\hline $\mathbf{6}$ & 2,87 & 6,53 & 2,85 & 6,48 & 4,56 & 10,37 \\
\hline $\mathbf{7}$ & 2,94 & 6,69 & 2,83 & 6,44 & 4,63 & 10,53 \\
\hline $\mathbf{8}$ & 2,84 & 6,46 & 2,93 & 6,67 & 4,49 & 10,21 \\
\hline $\mathbf{9}$ & 2,90 & 6,6 & 2,97 & 6,76 & 4,53 & 10,30 \\
\hline $\mathbf{1 0}$ & 2,85 & 6,48 & 2,92 & 6,64 & 4,24 & 9,65 \\
\hline $\mathbf{1 1}$ & 2,80 & 6,37 & 2,86 & 6,51 & 4,26 & 9,69 \\
\hline $\mathbf{1 2}$ & 2,82 & 6,41 & 3,01 & 6,85 & 4,32 & 9,83 \\
\hline $\mathbf{1 3}$ & 2,78 & 6,32 & 2,9 & 6,6 & 4,39 & 9,99 \\
\hline $\mathbf{1 4}$ & 2,61 & 5,94 & 3,02 & 6,87 & 4,25 & 9,67 \\
\hline $\mathbf{1 5}$ & 2,84 & 6,46 & 2,92 & 6,64 & 3,94 & 8,96 \\
\hline $\mathbf{1 6}$ & 2,63 & 5,98 & 3,09 & 7,03 & 4,51 & 10,26 \\
\hline $\mathbf{1 7}$ & 2,61 & 5,94 & 2,41 & 5,48 & 4,28 & 9,74 \\
\hline $\mathbf{1 8}$ & 2,77 & 6,3 & 2,55 & 5,80 & 4,07 & 9,26 \\
\hline $\mathbf{1 9}$ & 2,79 & 6,35 & 2,92 & 6,64 & 4,08 & 9,28 \\
\hline $\mathbf{2 0}$ & 2,78 & 6,32 & 2,81 & 6,39 & 4,16 & 9,46 \\
\hline $\mathbf{2 1}$ & 2,78 & 6,32 & 2,94 & 6,69 & 4,09 & 9,30 \\
\hline $\mathbf{2 2}$ & 2,58 & 5,87 & 2,78 & 6,32 & 4,09 & 9,30 \\
\hline $\mathbf{2 3}$ & 2,81 & 6,39 & 2,85 & 6,48 & 4,08 & 9,28 \\
\hline $\mathbf{2 4}$ & 2,73 & 6,21 & 2,80 & 6,37 & 4,01 & 9,12 \\
\hline $\mathbf{2 5}$ & 2,78 & 6,32 & 2,88 & 6,55 & 4,04 & 9,19 \\
\hline $\mathbf{2 6}$ & 2,79 & 6,35 & 2,82 & 6,41 & 3,87 & 8,80 \\
\hline $\mathbf{2 7}$ & 2,76 & 6,28 & 2,76 & 6,28 & 3,86 & 8,78 \\
\hline $\mathbf{2 8}$ & 2,49 & 5,66 & 2,97 & 6,76 & 3,86 & 8,78 \\
\hline $\mathbf{2 9}$ & 2,54 & 5,78 & 2,90 & 6,6 & 3,97 & 9,03 \\
\hline $\mathbf{3 0}$ & 2,74 & 6,23 & 2,95 & 6,71 & 3,89 & 8,85 \\
\hline & & & & & & \\
\hline & & & & \\
\hline & & & & & & \\
\hline
\end{tabular}


Tabela A. 10 - Tabela com os valores dos permeados coletados para o processo de microfiltração tangencial com membrana comercial com a primeira impregnação de prata, com 1,2 $\mu \mathrm{m}$ de tamanho médio dos poros; $200 \mathrm{~mm}$ de comprimento; $6,0 \mathrm{~mm}$ de diâmetro interno em regime de escoamento de transição de $R e \approx 3000$.

\begin{tabular}{|c|c|c|c|c|c|c|}
\hline \multirow[b]{2}{*}{ Tempo (minutos) } & \multicolumn{2}{|r|}{$1 \mathrm{bar}$} & \multicolumn{2}{|c|}{2 bar } & \multicolumn{2}{|c|}{3 bar } \\
\hline & $J(g)$ & $\mathrm{J}\left(\mathrm{L} / \mathrm{h} \cdot \mathrm{m}^{2}\right)$ & $J(g)$ & $\mathrm{J}\left(\mathrm{L} / \mathrm{h} \cdot \mathrm{m}^{2}\right)$ & $J(g)$ & $\mathrm{J}\left(\mathrm{L} / \mathrm{h} \cdot \mathrm{m}^{2}\right)$ \\
\hline 1 & 2,06 & 4,69 & 2,18 & 4,96 & 4,90 & 11,15 \\
\hline 2 & 2,47 & 5,62 & 2,15 & 4,89 & 4,36 & 9,92 \\
\hline 3 & 2,21 & 5,03 & 2,19 & 4,98 & 4,04 & 9,19 \\
\hline 4 & 2,35 & 5,35 & 2,27 & 5,16 & 3,58 & 8,14 \\
\hline 5 & 2,22 & 5,05 & 2,34 & 5,32 & 3,56 & 8,10 \\
\hline 6 & 2,17 & 4,94 & 2,25 & 5,12 & 3,62 & 8,23 \\
\hline 7 & 2,36 & 5,37 & 2,07 & 4,71 & 3,22 & 7,32 \\
\hline 8 & 2,08 & 4,73 & 2,19 & 4,98 & 3,30 & 7,51 \\
\hline 9 & 2,03 & 4,62 & 2,43 & 5,53 & 3,35 & 7,62 \\
\hline 10 & 2,18 & 4,96 & 2,20 & 5,0 & 2,34 & 5,32 \\
\hline 11 & 2,16 & 4,91 & 1,97 & 4,48 & 3,14 & 7,14 \\
\hline 12 & 2,16 & 4,91 & 2,28 & 5,19 & 3,35 & 7,62 \\
\hline 13 & 2,15 & 4,89 & 2,20 & 5,0 & 3,35 & 7,62 \\
\hline 14 & 2,15 & 4,89 & 2,31 & 5,25 & 3,03 & 6,89 \\
\hline 15 & 2,33 & 5,30 & 2,19 & 4,98 & 3,18 & 7,23 \\
\hline 16 & 1,89 & 4,30 & 2,43 & 5,53 & 3,38 & 7,69 \\
\hline 17 & 1,95 & 4,44 & 1,88 & 4,28 & 3,21 & 7,30 \\
\hline 18 & 2,04 & 4,64 & 2,19 & 4,98 & 2,73 & 6,21 \\
\hline 19 & 2,04 & 4,64 & 2,22 & 5,05 & 3,31 & 7,53 \\
\hline 20 & 2,13 & 4,85 & 2,09 & 4,75 & 3,09 & 7,03 \\
\hline 21 & 2,08 & 4,73 & 2,20 & 5,0 & 2,93 & 6,67 \\
\hline 22 & 2,01 & 4,57 & 2,21 & 5,03 & 3,11 & 7,07 \\
\hline 23 & 2,0 & 4,55 & 2,14 & 4,87 & 3,0 & 6,82 \\
\hline 24 & 2,02 & 4,60 & 2,63 & 5,98 & 2,95 & 6,71 \\
\hline 25 & 1,99 & 4,53 & 1,75 & 3,98 & 2,95 & 6,71 \\
\hline 26 & 1,87 & 4,25 & 2,21 & 5,03 & 3,04 & 6,92 \\
\hline 27 & 2,05 & 4,66 & 2,21 & 5,03 & 2,92 & 6,64 \\
\hline 28 & 1,98 & 4,50 & 2,15 & 4,89 & 2,89 & 6,57 \\
\hline 29 & 2,03 & 4,62 & 2,24 & 5,10 & 2,94 & 6,69 \\
\hline 30 & 2,0 & 4,55 & 2,31 & 5,25 & 4,18 & 9,51 \\
\hline
\end{tabular}


Tabela A. 11 - Tabela com os valores dos permeados coletados para o processo de microfiltração tangencial com membrana comercial com a segunda impregnação de prata, com 1,2 $\mu \mathrm{m}$ de tamanho médio dos poros; $200 \mathrm{~mm}$ de comprimento; $6,0 \mathrm{~mm}$ de diâmetro interno em regime de escoamento de transição de $R e \approx 4000$.

\begin{tabular}{c|c|c|c|c|c|c|c|c}
\hline $\begin{array}{c}\text { Tempo } \\
\text { (minutos) }\end{array}$ & \multicolumn{2}{|c|}{$\mathbf{~ b a r}$} & \multicolumn{2}{c|}{$\mathbf{2 ~ b a r}$} & \multicolumn{2}{c|}{$\mathbf{3}$ bar } & \multicolumn{2}{|c}{$\mathbf{4}$ bar } \\
\hline & $\mathrm{J}(\mathrm{g})$ & $\mathrm{J}\left(\mathrm{L} / \mathrm{h} \cdot \mathrm{m}^{2}\right)$ & $\mathrm{J}(\mathrm{g})$ & $\mathrm{J}\left(\mathrm{L} / \mathrm{h} \cdot \mathrm{m}^{2}\right)$ & $\mathrm{J}(\mathrm{g})$ & $\mathrm{J}\left(\mathrm{L} / \mathrm{h} \cdot \mathrm{m}^{2}\right)$ & $\mathrm{J}(\mathrm{g})$ & $\mathrm{J}\left(\mathrm{L} / \mathrm{h} \cdot \mathrm{m}^{2}\right)$ \\
\hline $\mathbf{5}$ & 88,08 & 40,05 & 106,38 & 48,37 & 18,97 & 8,63 & 103,55 & 47,09 \\
\hline $\mathbf{1 0}$ & 63,32 & 28,79 & 61,52 & 27,97 & 18,06 & 8,21 & 58,74 & 26,71 \\
\hline $\mathbf{1 5}$ & 59,64 & 27,12 & 47,48 & 21,59 & 17,73 & 8,06 & 48,18 & 21,91 \\
\hline $\mathbf{2 0}$ & 56,25 & 25,58 & 36,28 & 16,50 & 17,28 & 7,86 & 43,64 & 19,84 \\
\hline $\mathbf{2 5}$ & 52,35 & 23,81 & 28,08 & 12,77 & 17,38 & 7,90 & 38,03 & 17,29 \\
\hline $\mathbf{3 0}$ & 48,81 & 22,20 & 27,94 & 12,71 & 16,98 & 7,72 & 37,81 & 17,19 \\
\hline $\mathbf{3 5}$ & 45,63 & 20,75 & 27,42 & 12,47 & 18,06 & 8,21 & 34,22 & 15,56 \\
\hline $\mathbf{4 0}$ & 42,93 & 19,52 & 28,04 & 12,75 & 16,34 & 7,43 & 31,73 & 14,43 \\
\hline $\mathbf{4 5}$ & 42,80 & 19,46 & 29,19 & 13,27 & 17,70 & 8,05 & 29,56 & 13,44 \\
\hline $\mathbf{5 0}$ & 32,12 & 43,82 & 27,56 & 12,53 & 18,79 & 8,54 & 27,64 & 12,57 \\
\hline
\end{tabular}

Tabela A. 12 - Tabela com os valores dos permeados coletados para o processo de microfiltração tangencial com membrana comercial com a segunda impregnação de prata, com 1,2 $\mu \mathrm{m}$ de tamanho médio dos poros; $200 \mathrm{~mm}$ de comprimento; $6,0 \mathrm{~mm}$ de diâmetro interno em regime de escoamento de transição de $\mathrm{Re} \approx 3500$.

\begin{tabular}{c|c|c|c|c|c|c|c|c}
\hline \multirow{2}{*}{$\begin{array}{c}\text { Tempo } \\
\text { (minutos) }\end{array}$} & \multicolumn{2}{|c|}{$\mathbf{1}$ bar } & \multicolumn{2}{|c|}{$\mathbf{2}$ bar } & \multicolumn{2}{|c|}{$\mathbf{3}$ bar } & \multicolumn{2}{|c}{$\mathbf{4 ~ b a r}$} \\
\cline { 2 - 9 } & $\mathrm{J}(\mathrm{g})$ & $\mathrm{J}\left(\mathrm{L} / \mathrm{h} \cdot \mathrm{m}^{2}\right)$ & $\mathrm{J}(\mathrm{g})$ & $\mathrm{J}\left(\mathrm{L} / \mathrm{h} \cdot \mathrm{m}^{2}\right)$ & $\mathrm{J}(\mathrm{g})$ & $\mathrm{J}\left(\mathrm{L} / \mathrm{h} \cdot \mathrm{m}^{2}\right)$ & $\mathrm{J}(\mathrm{g})$ & $\mathrm{J}\left(\mathrm{L} / \mathrm{h} \cdot \mathrm{m}^{2}\right)$ \\
\hline $\mathbf{5}$ & 50,12 & 22,79 & 31,19 & 14,18 & 15,27 & 6,94 & 45,88 & 20,86 \\
\hline $\mathbf{1 0}$ & 25,98 & 11,81 & 24,28 & 11,04 & 15,48 & 7,04 & 30,62 & 13,92 \\
\hline $\mathbf{1 5}$ & 23,65 & 10,75 & 23,88 & 10,86 & 15,23 & 6,93 & 28,35 & 12,89 \\
\hline $\mathbf{2 0}$ & 21,34 & 9,70 & 23,42 & 10,65 & 16,68 & 7,58 & 25,49 & 11,59 \\
\hline $\mathbf{2 5}$ & 20,69 & 9,41 & 22,97 & 10,45 & 19,71 & 8,96 & 23,27 & 10,58 \\
\hline $\mathbf{3 0}$ & 19,38 & 8,81 & 22,40 & 10,19 & 14,84 & 6,75 & 22,29 & 10,14 \\
\hline $\mathbf{3 5}$ & 18,88 & 8,59 & 22,61 & 10,28 & 16,03 & 7,29 & 20,99 & 9,54 \\
\hline $\mathbf{4 0}$ & 18,41 & 8,37 & 22,19 & 10,09 & 15,89 & 7,23 & 20,29 & 9,23 \\
\hline $\mathbf{4 5}$ & 18,25 & 8,30 & 22,69 & 10,32 & 15,70 & 7,14 & 19,47 & 8,85 \\
\hline $\mathbf{5 0}$ & 17,63 & 8,02 & 21,89 & 9,95 & 16,04 & 7,29 & 18,79 & 8,54 \\
\hline
\end{tabular}

Tabela A. 13 - Tabela com os valores dos permeados coletados para o processo de microfiltração tangencial com membrana comercial com a segunda impregnação de prata, com 1,2 $\mathrm{mm}$ de tamanho médio dos poros; $200 \mathrm{~mm}$ de comprimento; $6,0 \mathrm{~mm}$ de diâmetro interno em regime de escoamento de transição de $R e \approx 3000$.

\begin{tabular}{c|c|c|c|c|c|c|c|c}
\hline \multirow{2}{*}{$\begin{array}{c}\text { Tempo } \\
\text { (minutos) }\end{array}$} & \multicolumn{2}{|c|}{$\mathbf{1}$ bar } & \multicolumn{2}{|c|}{$\mathbf{2 ~ b a r}$} & \multicolumn{2}{c|}{$\mathbf{3}$ bar } & \multicolumn{2}{c}{$\mathbf{4}$ bar } \\
\cline { 2 - 9 } & $\mathrm{J}(\mathrm{g})$ & $\mathrm{J}\left(\mathrm{L} / \mathrm{h} \cdot \mathrm{m}^{2}\right)$ & $\mathrm{J}(\mathrm{g})$ & $\mathrm{J}\left(\mathrm{L} / \mathrm{h} \cdot \mathrm{m}^{2}\right)$ & $\mathrm{J}(\mathrm{g})$ & $\mathrm{J}\left(\mathrm{L} / \mathrm{h} \cdot \mathrm{m}^{2}\right)$ & $\mathrm{J}(\mathrm{g})$ & $\mathrm{J}\left(\mathrm{L} / \mathrm{h} \cdot \mathrm{m}^{2}\right)$ \\
\hline $\mathbf{5}$ & 38,92 & 17,70 & 25,23 & 11,47 & 13,63 & 6,20 & 37,72 & 17,15 \\
\hline $\mathbf{1 0}$ & 20,75 & 9,44 & 19,07 & 8,67 & 13,55 & 6,16 & 21,70 & 9,87 \\
\hline $\mathbf{1 5}$ & 18,01 & 8,19 & 16,40 & 7,46 & 13,03 & 5,93 & 18,36 & 8,35 \\
\hline $\mathbf{2 0}$ & 16,44 & 7,48 & 16,66 & 7,58 & 13,27 & 6,03 & 17,67 & 8,04 \\
\hline $\mathbf{2 5}$ & 15,0 & 6,82 & 16,44 & 7,48 & 13,0 & 5,91 & 17,33 & 7,88 \\
\hline $\mathbf{3 0}$ & 14,38 & 6,54 & 16,08 & 7,31 & 13,09 & 5,95 & 16,57 & 7,53 \\
\hline $\mathbf{3 5}$ & 14,43 & 6,56 & 15,71 & 7,14 & 13,30 & 6,05 & 16,31 & 7,42 \\
\hline $\mathbf{4 0}$ & 14,22 & 6,47 & 15,49 & 7,04 & 13,44 & 6,11 & 16,16 & 7,35 \\
\hline $\mathbf{4 5}$ & 13,16 & 5,98 & 15,14 & 6,88 & 13,57 & 6,17 & 15,97 & 7,26 \\
\hline $\mathbf{5 0}$ & 13,53 & 6,15 & 14,59 & 6,63 & 12,95 & 5,89 & 15,82 & 7,19 \\
\hline
\end{tabular}


Tabela A. 14 - Tabela com os valores dos permeados coletados para o processo de microfiltração tangencial com tubo cerâmico sem impregnação de prata, com 0,4 $\mu \mathrm{m}$ de tamanho médio dos poros; $170 \mathrm{~mm}$ de comprimento; 7,0mm de diâmetro interno em regime de escoamento turbulento de $R e \approx 25000$.

\begin{tabular}{c|c|c|c|c|c|c|c|c}
\hline $\begin{array}{c}\text { Tempo } \\
\text { (minutos) }\end{array}$ & \multicolumn{2}{|c|}{ 1 bar } & \multicolumn{2}{|c|}{$\mathbf{2}$ bar } & \multicolumn{2}{|c|}{$\mathbf{3}$ bar } & \multicolumn{2}{|c}{$\mathbf{4 ~ b a r}$} \\
\cline { 2 - 10 } & $\mathrm{J}(\mathrm{g})$ & $\mathrm{J}\left(\mathrm{L} / \mathrm{h} \cdot \mathrm{m}^{2}\right)$ & $\mathrm{J}(\mathrm{g})$ & $\mathrm{J}\left(\mathrm{L} / \mathrm{h} \cdot \mathrm{m}^{2}\right)$ & $\mathrm{J}(\mathrm{g})$ & $\mathrm{J}\left(\mathrm{L} / \mathrm{h} \cdot \mathrm{m}^{2}\right)$ & $\mathrm{J}(\mathrm{g})$ & $\mathrm{J}\left(\mathrm{L} / \mathrm{h} \cdot \mathrm{m}^{2}\right)$ \\
\hline $\mathbf{5}$ & 9,76 & 31,33 & 20,34 & 65,29 & 6,60 & 21,19 & 23,91 & 76,75 \\
\hline $\mathbf{1 0}$ & 9,20 & 29,53 & 15,64 & 50,20 & 6,31 & 20,25 & 17,72 & 56,88 \\
\hline $\mathbf{1 5}$ & 8,83 & 28,34 & 13,47 & 43,24 & 6,69 & 21,47 & 15,99 & 51,33 \\
\hline $\mathbf{2 0}$ & 9,31 & 29,38 & 12,39 & 39,77 & 5,62 & 18,04 & 13,88 & 44,55 \\
\hline $\mathbf{2 5}$ & 8,69 & 27,89 & 10,71 & 34,38 & 6,44 & 20,67 & 13,97 & 44,84 \\
\hline $\mathbf{3 0}$ & 9,04 & 29,02 & 11,02 & 35,37 & 5,79 & 18,59 & 12,07 & 38,74 \\
\hline $\mathbf{3 5}$ & 8,91 & 28,60 & 10,10 & 32,42 & 6,10 & 19,58 & 10,92 & 35,05 \\
\hline $\mathbf{4 0}$ & 8,97 & 28,79 & 10,36 & 33,25 & 5,90 & 13,94 & 10,49 & 33,67 \\
\hline $\mathbf{4 5}$ & 8,68 & 27,86 & 9,06 & 29,08 & 5,94 & 19,07 & 9,90 & 31,78 \\
\hline $\mathbf{5 0}$ & 9,03 & 28,98 & 9,26 & 29,72 & 5,58 & 17,91 & 9,48 & 30,43 \\
\hline
\end{tabular}

Tabela A. 15 - Tabela com os valores dos permeados coletados para o processo de microfiltração tangencial com tubo cerâmico sem impregnação de prata, com $0,4 \mu \mathrm{m}$ de tamanho médio dos poros; $170 \mathrm{~mm}$ de comprimento; $7,0 \mathrm{~mm}$ de diâmetro interno em regime de escoamento turbulento de $\mathrm{Re} \approx 20000$.

\begin{tabular}{c|c|c|c|c|c|c|c|c}
\hline \multirow{2}{*}{$\begin{array}{c}\text { Tempo } \\
\text { (minutos) }\end{array}$} & \multicolumn{2}{|c|}{$\mathbf{1}$ bar } & \multicolumn{2}{|c|}{$\mathbf{2}$ bar } & \multicolumn{2}{c|}{$\mathbf{3 ~ b a r}$} & \multicolumn{2}{|c}{$\mathbf{4}$ bar } \\
\cline { 2 - 9 } & $\mathrm{J}(\mathrm{g})$ & $\mathrm{J}\left(\mathrm{L} / \mathrm{h} \cdot \mathrm{m}^{2}\right)$ & $\mathrm{J}(\mathrm{g})$ & $\mathrm{J}\left(\mathrm{L} / \mathrm{h} \cdot \mathrm{m}^{2}\right)$ & $\mathrm{J}(\mathrm{g})$ & $\mathrm{J}\left(\mathrm{L} / \mathrm{h} \cdot \mathrm{m}^{2}\right)$ & $\mathrm{J}(\mathrm{g})$ & $\mathrm{J}\left(\mathrm{L} / \mathrm{h} \cdot \mathrm{m}^{2}\right)$ \\
\hline $\mathbf{5}$ & 15,07 & 48,37 & 2,34 & 7,51 & 2,89 & 9,28 & 19,94 & 64,00 \\
\hline $\mathbf{1 0}$ & 11,33 & 36,37 & 1,91 & 6,13 & 3,08 & 9,89 & 12,44 & 39,93 \\
\hline $\mathbf{1 5}$ & 9,9 & 31,78 & 2,02 & 6,48 & 2,98 & 9,57 & 10,07 & 32,32 \\
\hline $\mathbf{2 0}$ & 9,18 & 29,47 & 1,92 & 6,16 & 2,93 & 9,40 & 9,07 & 29,11 \\
\hline $\mathbf{2 5}$ & 8,57 & 27,51 & 2,13 & 6,84 & 2,92 & 9,37 & 8,19 & 26,29 \\
\hline $\mathbf{3 0}$ & 8,20 & 26,32 & 2,18 & 7,00 & 1,88 & 6,03 & 6,98 & 22,40 \\
\hline $\mathbf{3 5}$ & 8,43 & 27,06 & 1,90 & 6,10 & 2,93 & 9,40 & 6,65 & 21,35 \\
\hline $\mathbf{4 0}$ & 7,63 & 24,49 & 1,97 & 6,32 & 2,96 & 9,50 & 5,09 & 16,34 \\
\hline $\mathbf{4 5}$ & 7,35 & 23,59 & 2,11 & 6,77 & 2,79 & 8,96 & 3,94 & 12,65 \\
\hline $\mathbf{5 0}$ & 7,15 & 22,95 & 2,23 & 7,16 & 3,01 & 9,66 & 4,07 & 13,06 \\
\hline
\end{tabular}

Tabela A. 16 - Tabela com os valores dos permeados coletados para o processo de microfiltração tangencial com tubo cerâmico sem impregnação de prata, com $0,4 \mu \mathrm{m}$ de tamanho médio dos poros; $170 \mathrm{~mm}$ de comprimento; $7,0 \mathrm{~mm}$ de diâmetro interno em regime de escoamento turbulento de $\mathrm{Re} \approx 17000$.

\begin{tabular}{c|c|c|c|c|c|c|c|c}
\hline \multirow{2}{*}{$\begin{array}{c}\text { Tempo } \\
\text { (minutos) }\end{array}$} & \multicolumn{2}{|c|}{ 1 bar } & \multicolumn{2}{|c|}{ 2 bar } & \multicolumn{2}{c|}{$\mathbf{3}$ bar } & \multicolumn{2}{|c}{$\mathbf{4 ~ b a r}$} \\
\cline { 2 - 9 } & $\mathrm{J}(\mathrm{g})$ & $\mathrm{J}\left(\mathrm{L} / \mathrm{h} \cdot \mathrm{m}^{2}\right)$ & $\mathrm{J}(\mathrm{g})$ & $\mathrm{J}\left(\mathrm{L} / \mathrm{h} \cdot \mathrm{m}^{2}\right)$ & $\mathrm{J}(\mathrm{g})$ & $\mathrm{J}\left(\mathrm{L} / \mathrm{h} \cdot \mathrm{m}^{2}\right)$ & $\mathrm{J}(\mathrm{g})$ & $\mathrm{J}\left(\mathrm{L} / \mathrm{h} \cdot \mathrm{m}^{2}\right)$ \\
\hline $\mathbf{5}$ & 5,20 & 16,69 & 2,40 & 7,70 & 4,03 & 12,94 & 14,30 & 45,90 \\
\hline $\mathbf{1 0}$ & 4,80 & 15,41 & 2,10 & 6,74 & 3,90 & 12,52 & 11,34 & 36,40 \\
\hline $\mathbf{1 5}$ & 4,97 & 15,95 & 2,72 & 8,73 & 3,83 & 12,29 & 8,75 & 28,09 \\
\hline $\mathbf{2 0}$ & 4,19 & 13,45 & 2,36 & 7,58 & 3,60 & 11,56 & 8,29 & 26,61 \\
\hline $\mathbf{2 5}$ & 4,58 & 14,70 & 2,46 & 7,90 & 3,75 & 12,04 & 7,33 & 23,53 \\
\hline $\mathbf{3 0}$ & 4,15 & 13,32 & 2,38 & 7,64 & 3,49 & 11,20 & 6,63 & 21,28 \\
\hline $\mathbf{3 5}$ & 4,13 & 13,26 & 2,49 & 7,99 & 3,45 & 11,07 & 6,41 & 20,58 \\
\hline $\mathbf{4 0}$ & 4,19 & 13,45 & 2,62 & 8,41 & 3,45 & 11,07 & 5,92 & 19,00 \\
\hline $\mathbf{4 5}$ & 3,75 & 12,04 & 2,28 & 7,32 & 3,48 & 11,17 & 5,80 & 18,62 \\
\hline $\mathbf{5 0}$ & 4,23 & 13,58 & 2,54 & 8,15 & 3,06 & 9,82 & 5,61 & 18,01 \\
\hline
\end{tabular}


Tabela A. 17 - Tabela com os valores dos permeados coletados para o processo de microfiltração tangencial com tubo cerâmico sem impregnação de prata, com 0,5 $\mu \mathrm{m}$ de tamanho médio dos poros; 190mm de comprimento;8,0mm de diâmetro interno em regime de escoamento turbulento de $\mathrm{Re} \approx 21000$.

\begin{tabular}{c|c|c|c|c|c|c|c|c}
\hline \multirow{2}{*}{$\begin{array}{c}\text { Tempo } \\
\text { (minutos) }\end{array}$} & \multicolumn{2}{|c|}{$\mathbf{1}$ bar } & \multicolumn{2}{|c|}{$\mathbf{2}$ bar } & \multicolumn{2}{|c|}{$\mathbf{3}$ bar } & \multicolumn{2}{|c}{$\mathbf{4 ~ b a r}$} \\
\cline { 2 - 9 } & $\mathrm{J}(\mathrm{g})$ & $\mathrm{J}\left(\mathrm{L} / \mathrm{h} \cdot \mathrm{m}^{2}\right)$ & $\mathrm{J}(\mathrm{g})$ & $\mathrm{J}\left(\mathrm{L} / \mathrm{h} \cdot \mathrm{m}^{2}\right)$ & $\mathrm{J}(\mathrm{g})$ & $\mathrm{J}\left(\mathrm{L} / \mathrm{h} \cdot \mathrm{m}^{2}\right)$ & $\mathrm{J}(\mathrm{g})$ & $\mathrm{J}\left(\mathrm{L} / \mathrm{h} \cdot \mathrm{m}^{2}\right)$ \\
\hline $\mathbf{5}$ & 4,68 & 11,76 & 7,84 & 19,70 & 5,14 & 12,92 & 18,29 & 45,96 \\
\hline $\mathbf{1 0}$ & 4,19 & 10,53 & 6,47 & 16,26 & 4,69 & 11,79 & 13,49 & 33,90 \\
\hline $\mathbf{1 5}$ & 4,90 & 12,31 & 5,85 & 14,70 & 4,35 & 10,93 & 10,43 & 26,21 \\
\hline $\mathbf{2 0}$ & 3,33 & 8,37 & 6,04 & 15,18 & 4,31 & 10,83 & 10,10 & 25,38 \\
\hline $\mathbf{2 5}$ & 4,06 & 10,20 & 5,78 & 14,52 & $\mathbf{4 , 2 2}$ & 10,60 & 10,09 & 25,36 \\
\hline $\mathbf{3 0}$ & 4,06 & 10,20 & 5,40 & 13,57 & 4,52 & 11,36 & 7,18 & 18,04 \\
\hline $\mathbf{3 5}$ & 4,04 & 10,15 & 5,45 & 13,70 & 4,39 & 11,03 & 6,87 & 17,26 \\
\hline $\mathbf{4 0}$ & 3,94 & 9,90 & 5,31 & 13,34 & 4,46 & 11,21 & 7,56 & 19,00 \\
\hline $\mathbf{4 5}$ & 3,93 & 9,88 & 5,26 & 13,22 & $\mathbf{4 , 4 5}$ & 11,18 & 4,67 & 11,74 \\
\hline $\mathbf{5 0}$ & 4,04 & 9,90 & 5,23 & 13,14 & 4,62 & 11,61 & 7,60 & 19,10 \\
\hline
\end{tabular}

Tabela A. 18 - Tabela com os valores dos permeados coletados para o processo de microfiltração tangencial com tubo cerâmico sem impregnação de prata, com $0,5 \mu \mathrm{m}$ de tamanho médio dos poros; $190 \mathrm{~mm}$ de comprimento; 8,0 mm de diâmetro interno em regime de escoamento turbulento de respectivamente $\mathrm{Re} \approx 18000$.

\begin{tabular}{c|c|c|c|c|c|c|c|c}
\hline \multirow{2}{*}{$\begin{array}{c}\text { Tempo } \\
\text { (minutos) }\end{array}$} & \multicolumn{2}{|c|}{$\mathbf{1}$ bar } & \multicolumn{2}{|c|}{$\mathbf{2 ~ b a r}$} & \multicolumn{2}{c|}{$\mathbf{3}$ bar } & \multicolumn{2}{|c}{$\mathbf{4 ~ b a r}$} \\
\cline { 2 - 9 } & $\mathrm{J}(\mathrm{g})$ & $\mathrm{J}\left(\mathrm{L} / \mathrm{h} \cdot \mathrm{m}^{2}\right)$ & $\mathrm{J}(\mathrm{g})$ & $\mathrm{J}\left(\mathrm{L} / \mathrm{h} \cdot \mathrm{m}^{2}\right)$ & $\mathrm{J}(\mathrm{g})$ & $\mathrm{J}\left(\mathrm{L} / \mathrm{h} \cdot \mathrm{m}^{2}\right)$ & $\mathrm{J}(\mathrm{g})$ & $\mathrm{J}\left(\mathrm{L} / \mathrm{h} \cdot \mathrm{m}^{2}\right)$ \\
\hline $\mathbf{5}$ & 11,45 & 28,77 & 3,35 & 8,42 & 5,03 & 12,64 & 16,67 & 41,89 \\
\hline $\mathbf{1 0}$ & 7,63 & 19,17 & 3,36 & 8,44 & 4,71 & 11,84 & 10,77 & 27,06 \\
\hline $\mathbf{1 5}$ & 6,64 & 16,69 & 3,38 & 8,49 & 4,74 & 11,91 & 8,83 & 22,19 \\
\hline $\mathbf{2 0}$ & 6,05 & 15,20 & 3,32 & 8,34 & 4,52 & 11,36 & 8,18 & 20,56 \\
\hline $\mathbf{2 5}$ & 5,99 & 15,05 & 3,36 & 8,44 & 4,73 & 11,89 & 5,14 & 12,92 \\
\hline $\mathbf{3 0}$ & 5,55 & 13,95 & 3,49 & 8,77 & 4,60 & 11,56 & 6,20 & 15,58 \\
\hline $\mathbf{3 5}$ & 5,77 & 14,50 & 3,32 & 8,34 & 4,51 & 11,33 & 6,12 & 15,38 \\
\hline $\mathbf{4 0}$ & 4,92 & 12,36 & 3,34 & 8,39 & 4,65 & 11,69 & 5,77 & 14,50 \\
\hline $\mathbf{4 5}$ & 5,84 & 14,68 & 3,18 & 7,99 & 4,43 & 11,13 & 5,78 & 14,52 \\
\hline $\mathbf{5 0}$ & 5,11 & 12,84 & 3,31 & 8,32 & 4,68 & 11,76 & 5,62 & 14,12 \\
\hline
\end{tabular}

Tabela A. 19 - Tabela com os valores dos permeados coletados para o processo de microfiltração tangencial com tubo cerâmico sem impregnação de prata, com 0,5 $\mu \mathrm{m}$ de tamanho médio dos poros; $190 \mathrm{~mm}$ de comprimento; $8,0 \mathrm{~mm}$ de diâmetro interno em regime de escoamento turbulento de $\operatorname{Re} \approx 15000$.

\begin{tabular}{c|c|c|c|c|c|c|c|c}
\hline \multirow{2}{*}{$\begin{array}{c}\text { Tempo } \\
\text { (minutos) }\end{array}$} & \multicolumn{2}{|c|}{$\mathbf{1}$ bar } & \multicolumn{2}{|c|}{ 2 bar } & \multicolumn{2}{c|}{ 3 bar } & \multicolumn{2}{c}{ 4 bar } \\
\cline { 2 - 9 } & $\mathrm{J}(\mathrm{g})$ & $\mathrm{J}\left(\mathrm{L} / \mathrm{h} \cdot \mathrm{m}^{2}\right)$ & $\mathrm{J}(\mathrm{g})$ & $\mathrm{J}\left(\mathrm{L} / \mathrm{h} \cdot \mathrm{m}^{2}\right)$ & $\mathrm{J}(\mathrm{g})$ & $\mathrm{J}\left(\mathrm{L} / \mathrm{h} \cdot \mathrm{m}^{2}\right)$ & $\mathrm{J}(\mathrm{g})$ & $\mathrm{J}\left(\mathrm{L} / \mathrm{h} \cdot \mathrm{m}^{2}\right)$ \\
\hline $\mathbf{5}$ & 0,14 & 0,35 & 0,12 & 0,30 & 0,11 & 0,28 & 0,74 & 1,86 \\
\hline $\mathbf{1 0}$ & 0,23 & 0,58 & 0,09 & 0,23 & 0,15 & 0,38 & 0,39 & 0,98 \\
\hline $\mathbf{1 5}$ & 0,20 & 0,50 & 0,13 & 0,33 & 0,16 & 0,40 & 0,37 & 0,93 \\
\hline $\mathbf{2 0}$ & 0,17 & 0,43 & 0,07 & 0,18 & 0,06 & 0,15 & 0,28 & 0,70 \\
\hline $\mathbf{2 5}$ & 0,20 & 0,50 & 0,07 & 0,18 & 0,06 & 0,15 & 0,22 & 0,55 \\
\hline $\mathbf{3 0}$ & 0,19 & 0,48 & 0,07 & 0,18 & 0,09 & 0,23 & 0,25 & 0,63 \\
\hline $\mathbf{3 5}$ & 0,16 & 0,40 & 0,08 & 0,20 & 0,10 & 0,25 & 0,27 & 0,68 \\
\hline $\mathbf{4 0}$ & 0,17 & 0,43 & 0,09 & 0,23 & 0,09 & 0,23 & 0,19 & 0,48 \\
\hline $\mathbf{4 5}$ & 0,19 & 0,48 & 0,10 & 0,25 & 0,14 & 0,35 & 0,21 & 0,53 \\
\hline $\mathbf{5 0}$ & 0,13 & 0,33 & 0,10 & 0,25 & 0,12 & 0,30 & 0,25 & 0,63 \\
\hline
\end{tabular}




\section{Anexo B- Resistência da membrana " $\mathbf{R}_{\mathrm{m}}$ ", Resistência total " $R_{\top}$ " e Resistência à formação da camada de polarização "R ${ }_{C}$ "}




\section{$\underline{\text { ANEXO B }}$}

\section{Resistência da membrana " $R_{m}$ ", Resistência total " $R_{T}$ " e Resistência à formação da camada de polarização " $R_{C}$ "}

Tabela B. 1 - Resistências da membrana comercial 0,8 $8 \mu \mathrm{m}$, para regimes de escoamento turbulento.

\begin{tabular}{|c|c|c|c|c|}
\hline \multirow{2}{*}{ - } & \multirow[b]{2}{*}{ 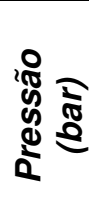 } & \multicolumn{3}{|c|}{ Membrana $(0,8 \mu m)$} \\
\hline & & $\mathrm{Re} \approx 30000$ & $\mathrm{Re} \approx 25000$ & $\mathrm{Re} \approx 20000$ \\
\hline $\mathbf{R}_{\mathbf{m}}$ & $\begin{array}{l}1 \\
2 \\
3 \\
4 \\
\end{array}$ & $\begin{array}{c}1,24 \cdot 10^{12} \\
2,09 \cdot 10^{12} \\
3,17.10^{12} \\
4,0.10^{12} \\
\end{array}$ & $\begin{array}{l}, 05 \cdot 10^{13} \\
1,06 \cdot 10^{13} \\
1,48 \cdot 10^{13} \\
8,61 \cdot 10^{12} \\
\end{array}$ & $\begin{array}{l}2,45.10^{13} \\
1,98.10^{13} \\
2,04.10^{13} \\
1,84.10^{13} \\
\end{array}$ \\
\hline $\mathbf{R}_{\mathbf{T}}$ & $\begin{array}{l}1 \\
2 \\
3 \\
4\end{array}$ & $\begin{array}{c}2,36 \cdot 10^{13} \\
5,19 \cdot 10^{13} \\
2,91 \cdot 10^{13} \\
{ }^{*} 6,90 \cdot 10^{12} / * * 1,19 \cdot 10^{13}\end{array}$ & $\begin{array}{c}3,19 \cdot 10^{13} \\
7,59 \cdot 10^{13} \\
4,93 \cdot 10^{13} \\
* 1,18 \cdot 10^{13} / * \star 2,70 \cdot 10^{13}\end{array}$ & $\begin{array}{c}{ }^{*} 3,34 \cdot 10^{13} / * * 5,23 \cdot 10^{13} \\
5,18 \cdot 10^{14} \\
3,93 \cdot 10^{14} \\
{ }^{*} 6,83 \cdot 10^{13} / * \star 2,06 \cdot 10^{14}\end{array}$ \\
\hline $\mathbf{R}_{\mathbf{C}}$ & $\begin{array}{l}1 \\
2 \\
3 \\
4\end{array}$ & $\begin{array}{c}2,24.10^{13} \\
4,98 \cdot 10^{13} \\
2,59 \cdot 10^{13} \\
* 2,9.10^{12} / * * 7,9.10^{12}\end{array}$ & 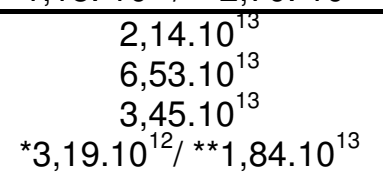 & $\begin{array}{c}{ }^{*} 8,9 \cdot 10^{12} /{ }^{* *} 2,78 \cdot 10^{13} \\
4,98 \cdot 10^{14} \\
3,73 \cdot 10^{14} \\
* 4,99.10^{13} /{ }^{* \star} 1,88 \cdot 10^{14}\end{array}$ \\
\hline
\end{tabular}

\footnotetext{
* Resistência obtida para os valores de permeado de 0 a 25 minutos do processo (polarização não estabelecida).

** Resistência obtida para os valores de permeado de 25 a 50 minutos do processo (polarização estabelecida).
} 
Tabela B. 2- Resistências da membrana comercial de $1,2 \mu \mathrm{m}$, sem impregnação de prata, para regimes de escoamento de transição.

\begin{tabular}{|c|c|c|c|c|}
\hline \multirow{2}{*}{ - } & \multirow{2}{*}{ 密 } & \multicolumn{3}{|c|}{ Membrana $(1,2 \mu m)$} \\
\hline & & $\mathrm{Re} \approx 4000$ & $\mathrm{Re} \approx 3500$ & $\mathrm{Re} \approx 3000$ \\
\hline $\mathbf{R}_{\mathrm{m}}$ & $\begin{array}{l}1 \\
2 \\
3 \\
4\end{array}$ & $\begin{array}{l}3,68 \cdot 10^{12} \\
5,27 \cdot 10^{12} \\
7,91 \cdot 10^{12} \\
7,52 \cdot 10^{12} \\
\end{array}$ & $\begin{array}{l}1,01 \cdot 10^{13} \\
1,08 \cdot 10^{13} \\
1,38 \cdot 10^{13} \\
1,35 \cdot 10^{13} \\
\end{array}$ & $\begin{array}{l}7,71.10^{12} \\
9,11.10^{12} \\
1,11.10^{13} \\
1,20.10^{13} \\
\end{array}$ \\
\hline $\mathbf{R}_{\mathbf{t}}$ & $\begin{array}{l}1 \\
2 \\
3 \\
\end{array}$ & $\begin{array}{c}4,32.10^{13} \\
7,19 \cdot 10^{13} \\
* 7,10.10^{13} / * * 8,03 \cdot 10^{13} \\
\end{array}$ & $\begin{array}{l}6,38 \cdot 10^{13} \\
8,95 \cdot 10^{13} \\
1,08 \cdot 10^{14} \\
\end{array}$ & $\begin{array}{c}{ }^{*} 6,52 \cdot 10^{13} /{ }^{* *} 6,15 \cdot 10^{13} \\
1,07 \cdot 10^{14} \\
{ }^{*} 1,20 \cdot 10^{14} / * \star 1,33 \cdot 10^{14} \\
\end{array}$ \\
\hline $\mathbf{R}_{\mathrm{C}}$ & $\begin{array}{l}1 \\
2 \\
3 \\
\end{array}$ & $\begin{array}{c}3,95 \cdot 10^{13} \\
6,66 \cdot 10^{13} \\
{ }^{*} 6,31 \cdot 10^{13} / * * 7,24 \cdot 10^{13}\end{array}$ & $\begin{array}{l}5,37 \cdot 10^{13} \\
7,87 \cdot 10^{13} \\
9,42 \cdot 10^{13} \\
\end{array}$ & $\begin{array}{c}5,75 \cdot 10^{13} / 5,38 \cdot 10^{13} \\
9,79 \cdot 10^{13} \\
* 1,09 \cdot 10^{14} / * \star 1,22 \cdot 10^{14} \\
\end{array}$ \\
\hline
\end{tabular}

* Resistência obtida para os valores de permeado de 0 a 25 minutos do processo (polarização não estabelecida).

** Resistência obtida para os valores de permeado de 25 a 50 minutos do processo (polarização estabelecida).

Tabela B. 3 - Resistências da membrana comercial de 1,2 $\mu$ m, com uma impregnação de prata, para regimes de escoamento de transição.

\begin{tabular}{|c|c|c|c|c|}
\hline \multirow{2}{*}{$\frac{d}{\frac{0}{d}}$} & \multirow[b]{2}{*}{ 蜜 } & \multicolumn{3}{|c|}{ Membrana $(1,2 \mu m)$} \\
\hline & & $\mathrm{Re} \approx 4000$ & $\mathrm{Re} \approx 3500$ & $\mathrm{Re} \approx 3000$ \\
\hline $\mathbf{R}_{\mathrm{m}}$ & $\begin{array}{l}1 \\
2 \\
3 \\
4\end{array}$ & $\begin{array}{l}3,68 \cdot 10^{12} \\
5,27 \cdot 10^{12} \\
7,91 \cdot 10^{12} \\
7,52 \cdot 10^{12}\end{array}$ & $\begin{array}{l}1,01 \cdot 10^{13} \\
1,08 \cdot 10^{13} \\
1,38 \cdot 10^{13} \\
1,35 \cdot 10^{13}\end{array}$ & $\begin{array}{l}7,71 \cdot 10^{12} \\
9,11 \cdot 10^{12} \\
1,11 \cdot 10^{13} \\
1,20 \cdot 10^{13}\end{array}$ \\
\hline $\mathbf{R}_{\mathrm{t}}$ & $\begin{array}{l}1 \\
2 \\
3\end{array}$ & $\begin{array}{l}{ }^{\star} 2,97 \cdot 10^{13} /{ }^{* *} 3,51 \cdot 10^{13} \\
{ }^{*} 5,62 \cdot 10^{13} /{ }^{* *} 6,53 \cdot 10^{13} \\
{ }^{*} 8,36 \cdot 10^{13} /{ }^{* *} 9,16 \cdot 10^{13}\end{array}$ & $\begin{array}{c}5,84 \cdot 10^{13} \\
1,12 \cdot 10^{13} \\
{ }^{*} 1,0.10^{14} /{ }^{* *} 1,19 \cdot 10^{14}\end{array}$ & $\begin{array}{c}7,67.10^{13} \\
1,47.10^{14} \\
* 1,39.10^{14} / * * 1,56.10^{14}\end{array}$ \\
\hline $\mathbf{R}_{\mathrm{C}}$ & $\begin{array}{l}1 \\
2 \\
3\end{array}$ & $\begin{array}{l}{ }^{*} 2,60 \cdot 10^{13} /{ }^{* *} 3,14 \cdot 10^{13} \\
{ }^{\star} 5,09 \cdot 10^{13} /{ }^{* *} 6,0 \cdot 10^{13} \\
{ }^{*} 7,57 \cdot 10^{13} /{ }^{* *} 8,37 \cdot 10^{13}\end{array}$ & $\begin{array}{c}4,83 \cdot 10^{13} \\
4,0 \cdot 10^{11} \\
* 8,62 \cdot 10^{13} / * * 1,05 \cdot 10^{14}\end{array}$ & $\begin{array}{c}6,90 \cdot 10^{13} \\
1,38 \cdot 10^{14} \\
* 1,28 \cdot 10^{14} /{ }^{* *} 1,45 \cdot 10^{14}\end{array}$ \\
\hline
\end{tabular}

* Resistência obtida para os valores de permeado de 0 a 25 minutos do processo (polarização não estabelecida).

** Resistência obtida para os valores de permeado de 25 a 50 minutos do processo (polarização estabelecida). 
Tabela B. 4 - Resistências da membrana comercial de 1,2 $\mu \mathrm{m}$, com duas impregnações de prata, para regimes de escoamento de transição.

\begin{tabular}{|c|c|c|c|c|}
\hline \multirow{2}{*}{$\frac{-1}{0}$} & \multirow[b]{2}{*}{ 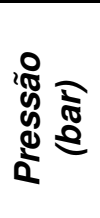 } & \multicolumn{3}{|c|}{ Membrana $(1,2 \mu \mathrm{m})$} \\
\hline & & $\mathrm{Re} \approx 4000$ & $\mathrm{Re} \approx 3500$ & $\mathrm{Re} \approx 3000$ \\
\hline $\mathbf{R}_{\mathrm{m}}$ & $\begin{array}{l}1 \\
2 \\
3 \\
4\end{array}$ & $\begin{array}{l}3,68 \cdot 10^{12} \\
5,27 \cdot 10^{12} \\
7,91 \cdot 10^{12} \\
7,52 \cdot 10^{12}\end{array}$ & $\begin{array}{l}1,01 \cdot 10^{13} \\
1,08 \cdot 10^{13} \\
1,38 \cdot 10^{13} \\
1,35 \cdot 10^{13}\end{array}$ & $\begin{array}{l}7,71 \cdot 10^{12} \\
9,11 \cdot 10^{12} \\
1,11 \cdot 10^{13} \\
1,20 \cdot 10^{13}\end{array}$ \\
\hline $\mathbf{R}_{\mathrm{t}}$ & $\begin{array}{l}1 \\
2 \\
3 \\
4\end{array}$ & $\begin{array}{c}{ }^{*} 1,26 \cdot 10^{13} /^{* *} 1,46 \cdot 10^{13} \\
{ }^{*} 2,89 \cdot 10^{13} /{ }^{* *} 5,76 \cdot 10^{13} \\
1,37.10^{14} \\
{ }^{*} 5,53 \cdot 10^{13} /{ }^{* *} 1,0.10^{14}\end{array}$ & $\begin{array}{c}{ }^{\star} 2,85 \cdot 10^{13} /^{* *} 4,36 \cdot 10^{13} \\
{ }^{*} 6,42 \cdot 10^{13} /{ }^{* *} 7,22 \cdot 10^{13} \\
1,51 \cdot 10^{14} \\
{ }^{*} 1,05 \cdot 10^{14} /{ }^{* *} 1,59 \cdot 10^{14}\end{array}$ & $\begin{array}{c}{ }^{*} 3,70 \cdot 10^{13} /^{* *} 5,79 \cdot 10^{13} \\
{ }^{*} 8,61.10^{13} /{ }^{* *} 1,05 \cdot 10^{14} \\
1,82.10^{14} \\
{ }^{*} 1,43.10^{14} /{ }^{* *} 2,0.10^{14}\end{array}$ \\
\hline $\mathbf{R}_{\mathrm{C}}$ & $\begin{array}{l}1 \\
2 \\
3 \\
4\end{array}$ & $\begin{array}{c}{ }^{*} 8,92 \cdot 10^{12} / * * 1,09 \cdot 10^{13} \\
{ }^{*} 2,36 \cdot 10^{13} / * \star 5,23 \cdot 10^{13} \\
1,29 \cdot 10^{13} \\
{ }^{*} 4,78 \cdot 10^{13} / * * 9,25 \cdot 10^{13}\end{array}$ & $\begin{array}{c}{ }^{*} 1,84 \cdot 10^{13} /{ }^{* *} 3,35 \cdot 10^{13} \\
{ }^{*} 5,34 \cdot 10^{13} /{ }^{* *} 6,14 \cdot 10^{13} \\
1,37.10^{14} \\
{ }^{*} 9,15 \cdot 10^{13} /{ }^{* *} 1,46 \cdot 10^{14}\end{array}$ & $\begin{array}{c}{ }^{*} 2,93 \cdot 10^{13} /{ }^{* *} 5,02 \cdot 10^{13} \\
{ }^{13}, 70.10^{13} /{ }^{* *} 9,59 \cdot 10^{13} \\
1,71 \cdot 10^{14} \\
{ }^{*} 1,31.10^{14} /{ }^{* *} 1,88 \cdot 10^{14}\end{array}$ \\
\hline
\end{tabular}

* Resistência obtida para os valores de permeado de 0 a 25 minutos do processo (polarização não estabelecida).

** Resistência obtida para os valores de permeado de 25 a 50 minutos do processo (polarização estabelecida).

Tabela B. 5 - Resistências do tubo cerâmico 0,4 $\mu \mathrm{m}$ para regimes de escoamento turbulento.

\begin{tabular}{|c|c|c|c|c|}
\hline \multirow{2}{*}{ 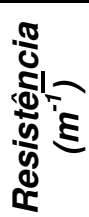 } & \multirow[b]{2}{*}{ 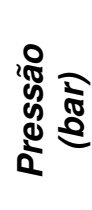 } & \multicolumn{3}{|c|}{ Tubo cerâmico $(0,4 \mu \mathrm{m})$} \\
\hline & & $\operatorname{Re} \approx 25000$ & $\operatorname{Re} \approx 20000$ & $\operatorname{Re} \approx 17000$ \\
\hline $\mathbf{R}_{\mathbf{m}}$ & $\begin{array}{l}1 \\
2 \\
3 \\
4 \\
\end{array}$ & $\begin{array}{l}1,37 \cdot 10^{12} \\
1,89 \cdot 10^{13} \\
4,32 \cdot 10^{12} \\
6,67 \cdot 10^{12} \\
\end{array}$ & $\begin{array}{l}8,36 \cdot 10^{12} \\
7,73 \cdot 10^{12} \\
8,05 \cdot 10^{12} \\
9,27 \cdot 10^{12} \\
\end{array}$ & $\begin{array}{l}7,79 \cdot 10^{12} \\
8,46 \cdot 10^{12} \\
8,64 \cdot 10^{12} \\
8,99 \cdot 10^{12} \\
\end{array}$ \\
\hline $\mathbf{R}_{\mathbf{t}}$ & $\begin{array}{l}1 \\
2 \\
3 \\
4\end{array}$ & $\begin{array}{c}1,27.10^{13} \\
{ }^{*} 1,58 \cdot 10^{13} / * \star 2,30.10^{13} \\
5,63 \cdot 10^{13} \\
\star 2,68.10^{13} / * * 4,33 \cdot 10^{13}\end{array}$ & $\begin{array}{c}{ }^{*} 1,06.10^{13} /{ }^{* *} 1,48.10^{13} \\
1,10.10^{14} \\
1,21.10^{14} \\
{ }^{*} 3,85.10^{13} /{ }^{* *} 8,55.10^{13}\end{array}$ & $\begin{array}{c}2,59 \cdot 10^{13} \\
9,4.10^{13} \\
9,53.10^{13} \\
* 4,57.10^{13} / * \star 7,53.10^{13}\end{array}$ \\
\hline $\mathbf{R}_{\mathbf{C}}$ & $\begin{array}{l}1 \\
2 \\
3 \\
4\end{array}$ & $\begin{array}{c}1,13.10^{13} \\
\star 3,10.10^{12} / * * 4,10.10^{12} \\
5,2.10^{13} \\
\star 2,01.10^{13} / * * 3,66.10^{13}\end{array}$ & $\begin{array}{c}{ }^{\star} 2,24 \cdot 10^{12} /{ }^{* *} 6,44 \cdot 10^{12} \\
1,02 \cdot 10^{14} \\
1,13 \cdot 10^{14} \\
{ }^{*} 2,92 \cdot 10^{13} / * * 7,62 \cdot 10^{13}\end{array}$ & $\begin{array}{c}1,81 \cdot 10^{13} \\
8,55 \cdot 10^{13} \\
8,67.10^{13} \\
* 3,67.10^{13} /^{* *} 6,63 \cdot 10^{13}\end{array}$ \\
\hline
\end{tabular}

\footnotetext{
${ }^{*}$ Resistência obtida para os valores de permeado de 0 a 25 minutos do processo (polarização não estabelecida).

** Resistência obtida para os valores de permeado de 25 a 50 minutos do processo (polarização estabelecida).
} 
Tabela B. 6 - Resistências do tubo cerâmico $0,5 \mu$ m para regimes de escoamento turbulento.

\begin{tabular}{|c|c|c|c|c|}
\hline \multirow{2}{*}{ 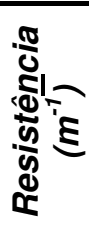 } & \multirow[b]{2}{*}{ 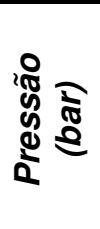 } & \multicolumn{3}{|c|}{ Tubo cerâmico $(0,5 \mu \mathrm{m})$} \\
\hline & & $\mathrm{Re} \approx 21000$ & $\mathrm{Re} \approx 18000$ & $R e \approx 15000$ \\
\hline $\mathbf{R}_{\mathrm{m}}$ & $\begin{array}{l}1 \\
2 \\
3 \\
4\end{array}$ & $\begin{array}{l}8,72 \cdot 10^{13} \\
6,22 \cdot 10^{13} \\
5,45 \cdot 10^{13} \\
4,80 \cdot 10^{13}\end{array}$ & $\begin{array}{l}3,72 \cdot 10^{13} \\
2,94 \cdot 10^{13} \\
2,62 \cdot 10^{13} \\
2,51 \cdot 10^{13}\end{array}$ & $\begin{array}{l}2,81 \cdot 10^{13} \\
1,93 \cdot 10^{13} \\
2,56 \cdot 10^{13} \\
2,52 \cdot 10^{13}\end{array}$ \\
\hline $\mathbf{R}_{\mathrm{t}}$ & $\begin{array}{l}1 \\
2 \\
3 \\
4\end{array}$ & $\begin{array}{c}3,55 \cdot 10^{13} \\
* 4,57 \cdot 10^{13} /{ }^{* *} 5,49 \cdot 10^{13} \\
9,72 \cdot 10^{13} \\
* 4,69 \cdot 10^{13} / * * 8,63 \cdot 10^{13}\end{array}$ & $\begin{array}{c}{ }^{\star} 1,94.10^{13} /^{* *} 5,38.10^{13} \\
8,76.10^{13} \\
9,42.10^{13} \\
5,9.10^{13} / 9,92.10^{13}\end{array}$ & $\begin{array}{c}8,22 \cdot 10^{14} \\
3,21.10^{15} \\
4,06 \cdot 10^{15} \\
{ }^{*} 1,46.10^{15} / * * 2,5.10^{15}\end{array}$ \\
\hline $\mathbf{R}_{\mathbf{C}}$ & $\begin{array}{l}1 \\
2 \\
3 \\
4\end{array}$ & $\begin{array}{c}5,17.10^{13} \\
* 1,65 \cdot 10^{13} / * * 7,36 \cdot 10^{12} \\
4,27.10^{13} \\
* 1,12 \cdot 10^{12} / * \star 3,83 \cdot 10^{13}\end{array}$ & $\begin{array}{c}{ }^{\star} 1,78 \cdot 10^{13} /{ }^{* *} 1,66 \cdot 10^{13} \\
5,82 \cdot 10^{13} \\
6,8.10^{13} \\
{ }^{*} 3,39 \cdot 10^{13} /{ }^{* *} 7,41 \cdot 10^{13}\end{array}$ & $\begin{array}{c}7,94 \cdot 10^{14} \\
3,19 \cdot 10^{15} \\
4,03 \cdot 10^{15} \\
* 1,44.10^{15} / * * 2,48.10^{15}\end{array}$ \\
\hline
\end{tabular}

\footnotetext{
* Resistência obtida para os valores de permeado de 0 a 25 minutos do processo (polarização não estabelecida).

** Resistência obtida para os valores de permeado de 25 a 50 minutos do processo (polarização estabelecida).
} 
Anexo C - Registro Fotográfico das Análises Microbiológicas (Exemplos) 


\section{$\underline{\text { Anexo C }}$}

\section{ReGISTRO FotográfICO dAS ANÁlises MICROBIOLÓGICAS (EXEMPLOS)}

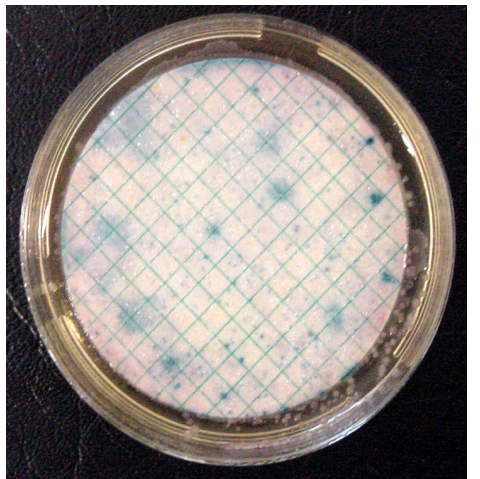

(a)

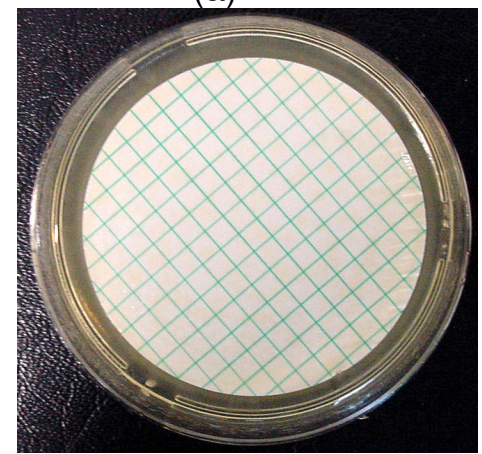

(d)

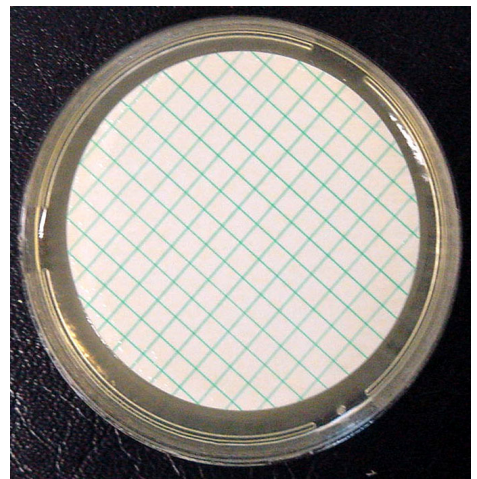

(b)

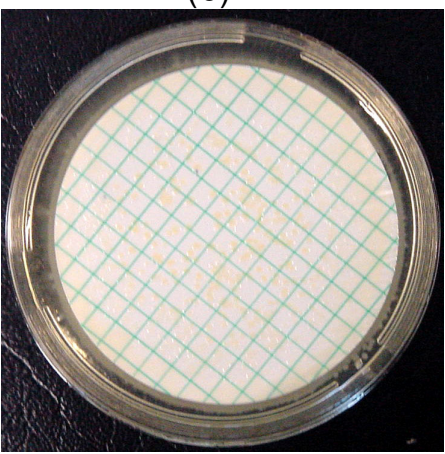

(e)

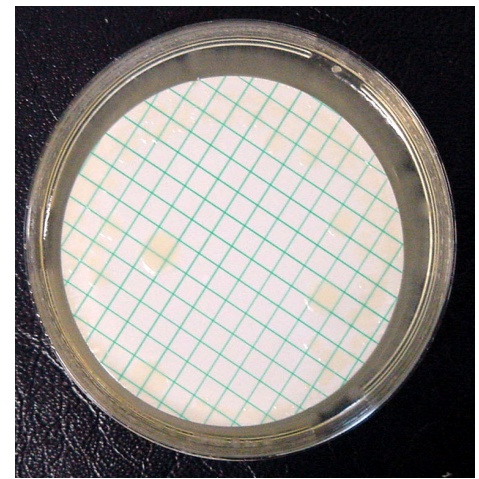

(c)

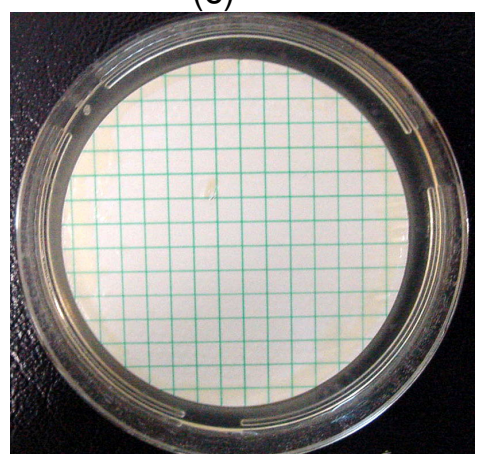

(f)

Figura 1. Microfiltração da suspensão de leite de búfala com o Tubo Monocamada de $0,5 \mu \mathrm{m}$. (a) coleta da suspensão processada; (b) coleta do permeado após 10 minutos de filtração; (c) coleta do permeado após 20 minutos de filtração; (d) coleta do permeado após 30 minutos de filtração; (e) coleta do permeado após 40 minutos de filtração; (f) coleta do permeado após 50 minutos de filtração. 


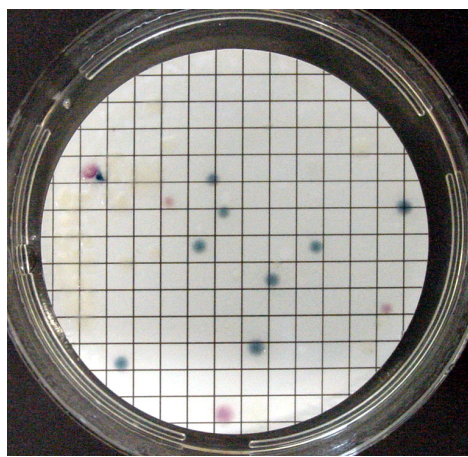

(a)

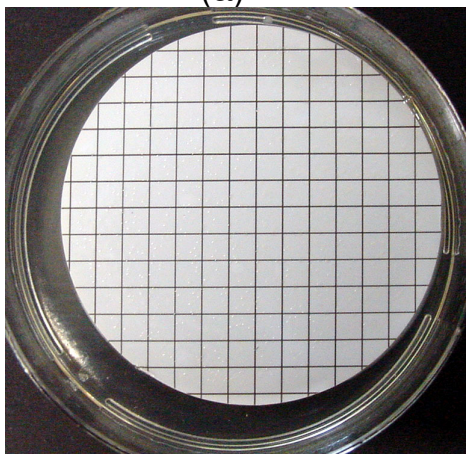

(d)

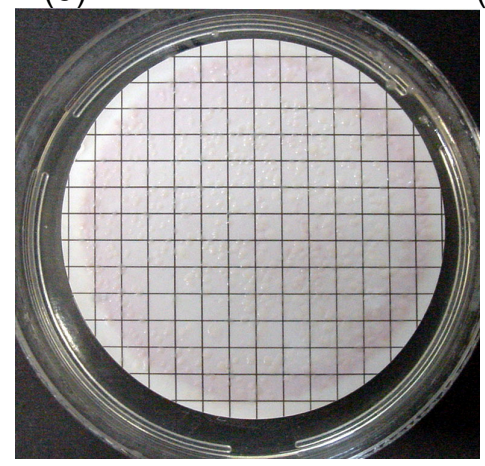

(g)

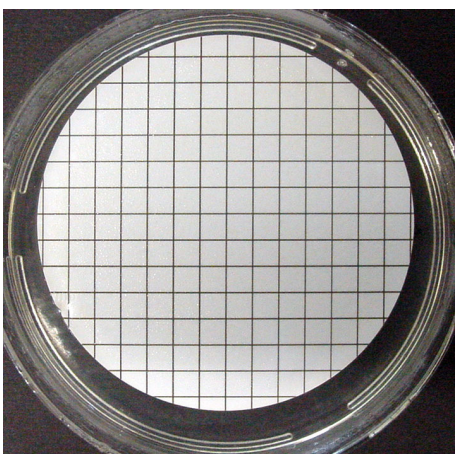

(b)

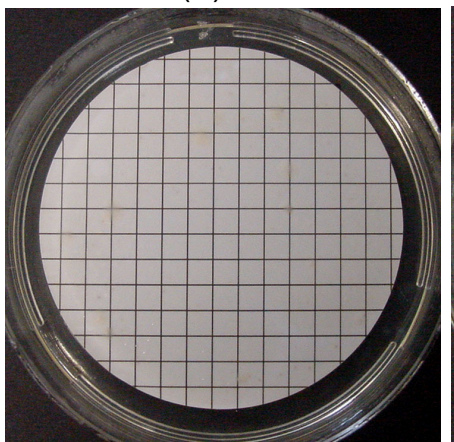

(e)

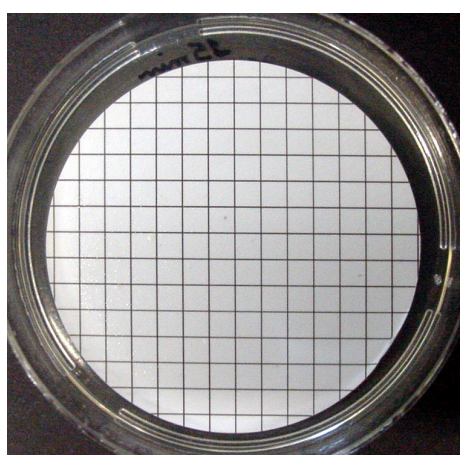

(c)

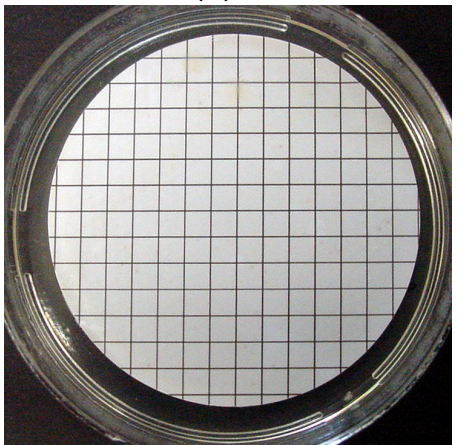

(f)

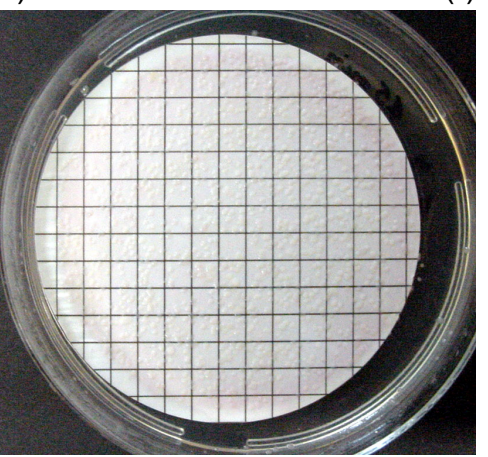

(h)

Figura 2. Microfiltração da suspensão do soro de leite com a membrana comercial de 0,8 $\mu \mathrm{m}$ sem impregnação - Re 21000 . (a) coleta do permeado - 1bar; 15 min.; (b) coleta do permeado - 1bar; 45 min.; (c) coleta do permeado - 2bar; 15 min.; (d) coleta do permeado - 2bar; 45 min.; (e) coleta do permeado - 3 bar; 15 min.; (f) coleta do permeado - 3 bar; 45 min.; (g) coleta do permeado - 4 bar; 15 min.; (h) coleta do permeado - 4 bar; 45 min.. 


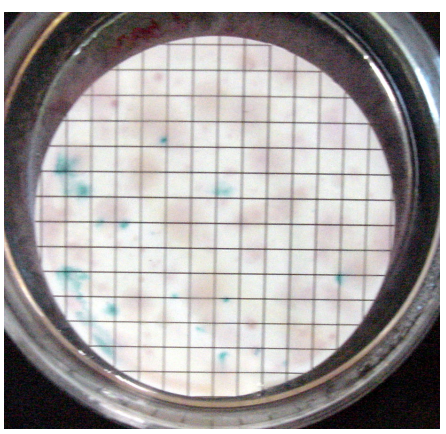

(a)

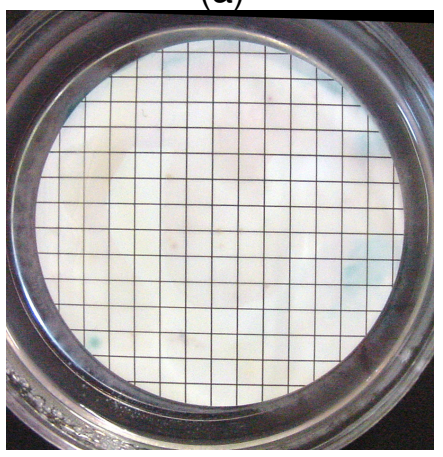

(d)

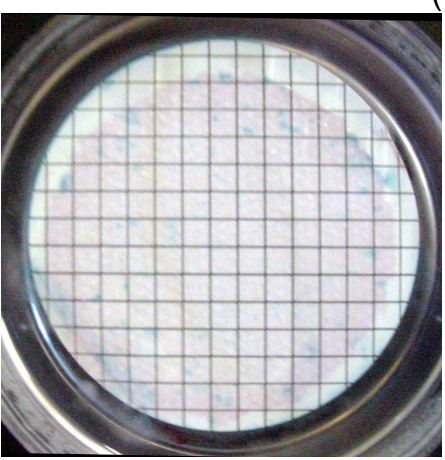

(g)

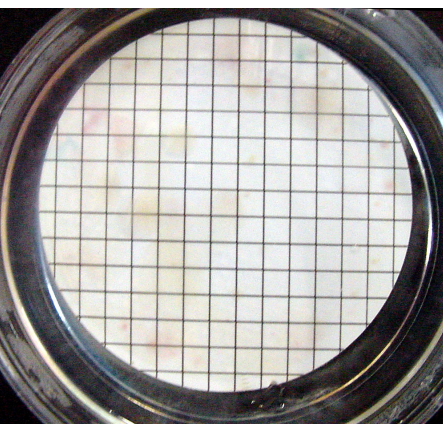

(b)

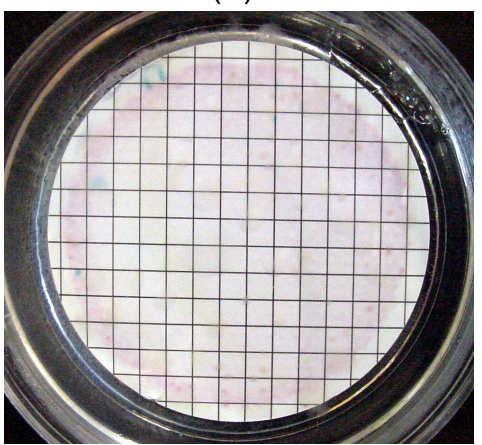

(e)

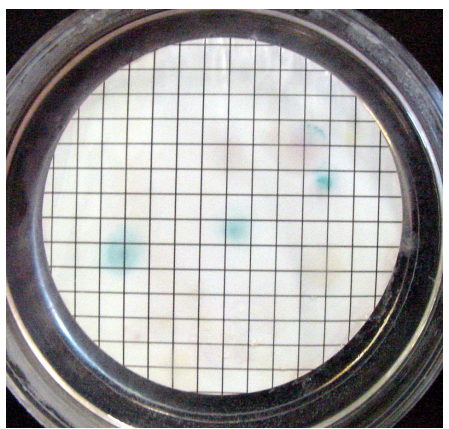

(c)

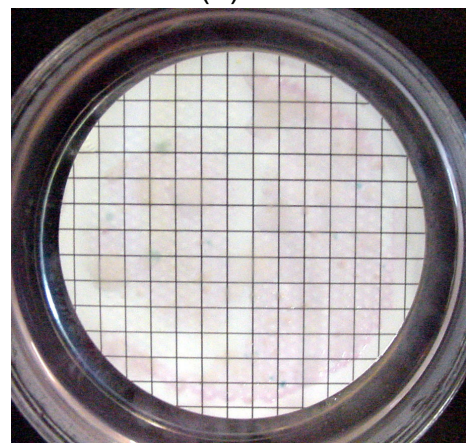

(f)

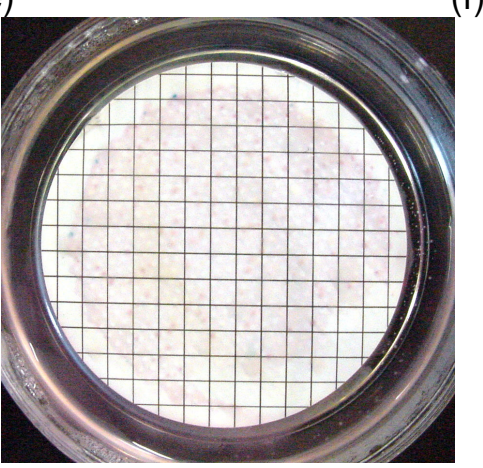

(h)

Figura 3. Microfiltração da suspensão do soro de leite com a membrana comercial de 0,8 um com impregnação - Re $\approx 15000$. (a) coleta do permeado - 1bar; 15 min.; (b) coleta do permeado - 1bar; 45 min.; (c) coleta do permeado - 2bar; 15 min.; (d) coleta do permeado - 2bar; 45 min.; (e) coleta do permeado - 3 bar; 15 min.; (f) coleta do permeado - 3 bar; 45 min.; (g) coleta do permeado - 4 bar; 15 min.; (h) coleta do permeado - 4 bar; 45 min.. 